\title{
Grand Junction Projects Office Site Environmental Report for Calendar Year 1992
}

\author{
May 1993
}

Work performed under DOE Contract No. DE-AC04-86ID12584 for the U.S. Department of Energy Grand Junction Projects Office 
This report was prepared as an account of work sponsored by an agency of the United States Government. Neither the United States Government nor any agency thereof, nor any of their employees, makes any warranty, express or implied, or assumes any legal liability or responsibility for the accuracy, completeness, or usefulness of any information, apparatus, product, or process disclosed in this report, or represents that its use would not infringe privately owned rights. Reference herein to any specific commercial product, process, or service by trade name, trademark, manufacturer, or otherwise, does not necessarily constitute or imply its endorsement, recommendation, or favoring by the United States Government or any agency thereof.. The views and opinions of authors expressed herein do not necessarily state or reflect those of the United States Government or any agency thereof. 
Grand. Junction Projects Office

Site Environmental Report for Calendar Year 1992
MCOLIVE-

FEB 22 1934.

OSTI

May 1993

Prepared for

the U.S. Department of Energy

Grand Junction Projects Office

Albuquerque Field Office

P.O. Box 2567

Grand Junction, CO 81502-2567

Prepared by

RUST Geotech Inc.

P.O. Box 14000

Grand Junction, Colorado 81502 


\section{Contents}

Page

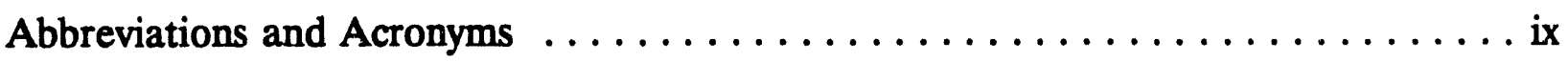

Executive Summary $\ldots \ldots \ldots \ldots \ldots \ldots \ldots \ldots \ldots \ldots \ldots \ldots \ldots \ldots \ldots \ldots$

Introduction $\ldots \ldots \ldots \ldots \ldots \ldots \ldots \ldots \ldots \ldots \ldots \ldots \ldots \ldots \ldots \ldots \ldots \ldots \ldots \ldots$

Compliance Summary - January 1, 1992, through April 1, $1993 \ldots \ldots \ldots \ldots \ldots 6$

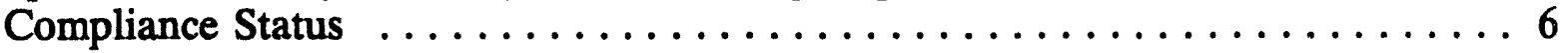

Comprehensive Environmental Response, Compensation, and

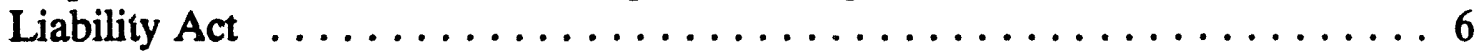

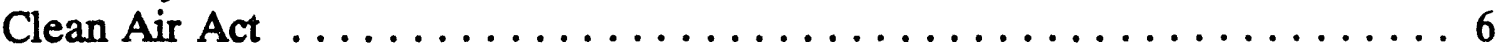

Clean Water Act ............................... 7

Executive Order 11988 "Floodplain Management" . . . . . . . . . . . 8

Resource Conservation and Recovery Act $\ldots \ldots \ldots \ldots \ldots \ldots \ldots \ldots$

National Environmental Policy Act $\ldots \ldots \ldots \ldots \ldots \ldots \ldots \ldots \ldots$

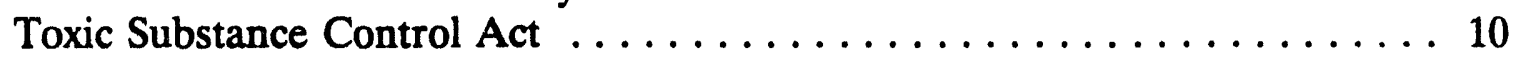

Current Issues and Actions $\ldots \ldots \ldots \ldots \ldots \ldots \ldots \ldots \ldots \ldots \ldots \ldots \ldots$

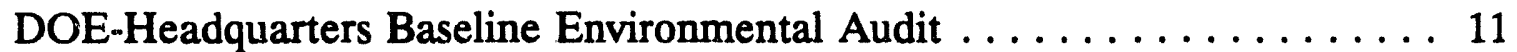

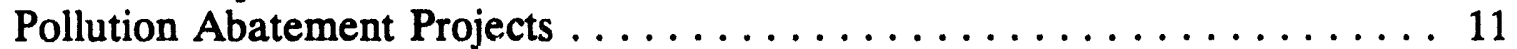

Pollution Prevention Awareness Program . . . . . . . . . . . . . . 11

Waste Management .......................... 11

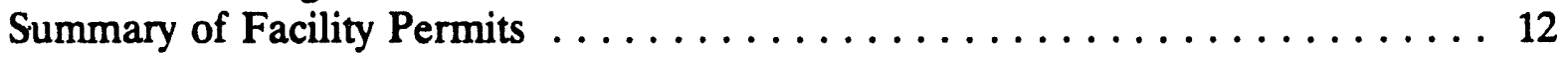

Environmental Program Information $\ldots \ldots \ldots \ldots \ldots \ldots \ldots \ldots \ldots \ldots \ldots$



Environmental Monitoring Summary $\ldots \ldots \ldots \ldots \ldots \ldots \ldots \ldots \ldots \ldots$

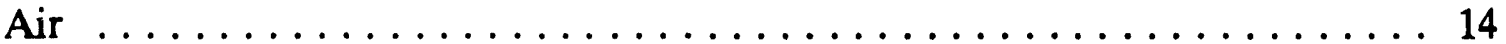

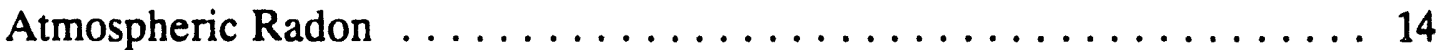

Air Particulates ........................... 16

Radionuclide Point Source Emissions $\ldots \ldots \ldots \ldots \ldots \ldots \ldots \ldots \ldots$

Direct Gamma Radiation Monitoring . ............... 20

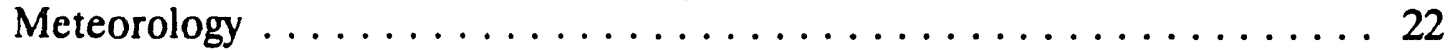

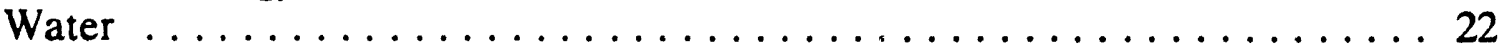

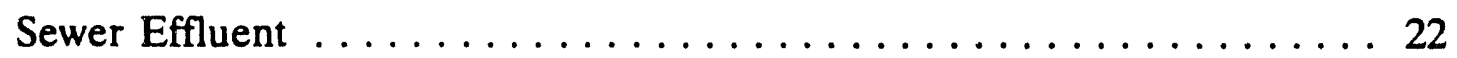

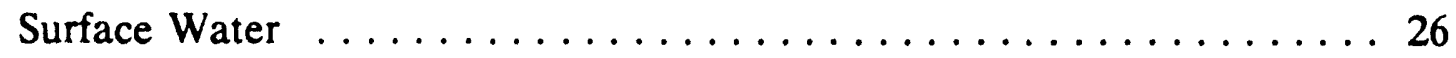

Environmental Permits and Document Preparation ............... 29

Environmental Activities . . . . . . . . . . . . . . . . . . . . 30

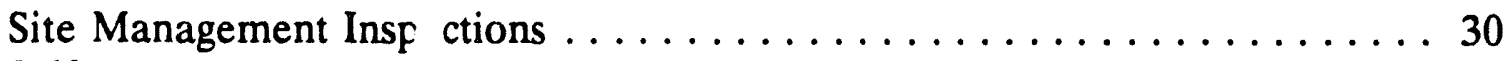

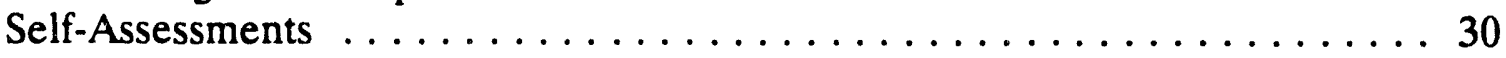

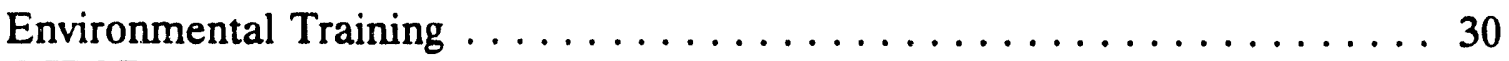

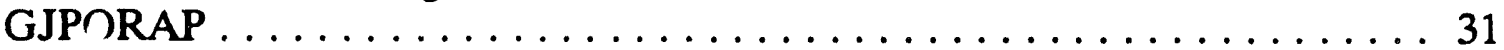

Commingled Waste Investigation Project $\ldots \ldots \ldots \ldots \ldots \ldots \ldots \ldots \ldots$ 
Contents (continued)

Page

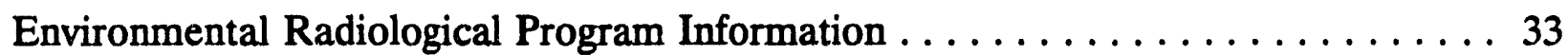

Radioactive Effluent Data . . . . . . . . . . . . . . . . . . . 33

Environmental Sampling for Radioactivity ................. 36

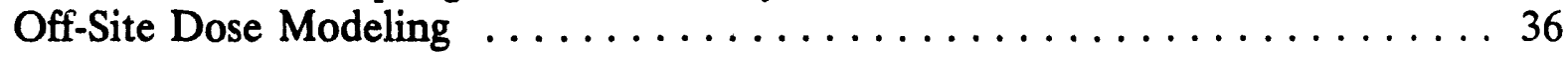

Environmental Nonradiological Program Information $\ldots \ldots \ldots \ldots \ldots \ldots$

Nonradiological Effluent Data . . . . . . . . . . . . . . . . . 37

Environmental Sampling for Nonradiological Pollution $\ldots \ldots \ldots \ldots \ldots \ldots 37$

SARA, Title III, Reporting . ....................... 38

Ground Water Protection Program .......................... 39

Hydrogeology .................................. 39

Ground Water Monitoring Program $\ldots \ldots \ldots \ldots \ldots \ldots \ldots \ldots \ldots \ldots \ldots$

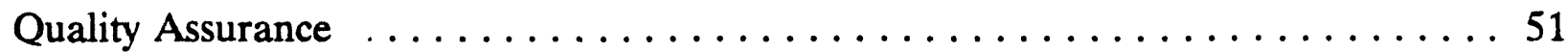

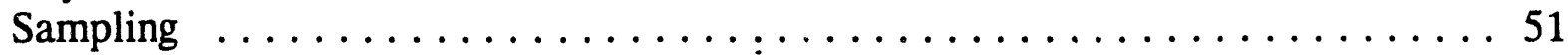

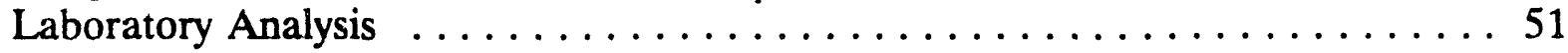

Interlaboratory Quality Assurance Programs $\ldots \ldots \ldots \ldots \ldots \ldots \ldots \ldots 2$

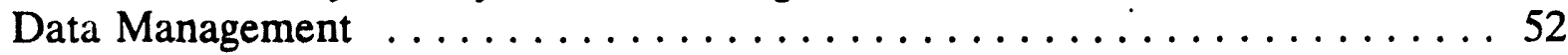

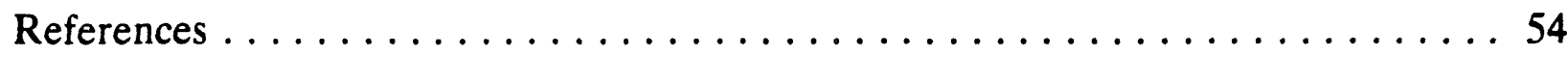

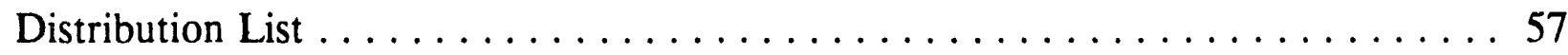

Appendix A, Monitoring Data $\ldots \ldots \ldots \ldots \ldots \ldots \ldots \ldots \ldots \ldots \ldots \ldots \ldots \ldots \ldots \ldots$

Appendix B, Time-Concentration Graphs $\ldots \ldots \ldots \ldots \ldots \ldots \ldots \ldots$ B-1

Appendix C, Well Location Maps Showing Ground-Water Analytes that

Exceed Federal/State Standards $\ldots \ldots \ldots \ldots \ldots \ldots \ldots \ldots \ldots \ldots$ C-1

Figures

Figure 1. Site Location Map of the GJPO $\ldots \ldots \ldots \ldots \ldots \ldots \ldots \ldots \ldots$

2. Map of the GJPO Facility Showing Areas of Tailings

Contamination and Remediation ...................4

3. Atmospheric Radon Sample Locations at the GJPO Facility and Vicinity ............................ 15

4. Air Particulate Sampling Locations at the GJPO Facility $\ldots \ldots \ldots \ldots$ 
Figures (continued)

Page

5. Direct Gamma Radiation Monitoring Stations at the GJPO Facility

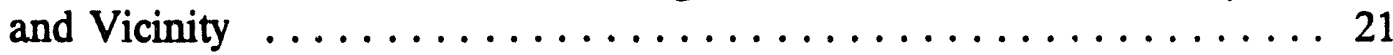

6. Sewer Effluent Sampling Location at the GJPO Facility . . . . . . 25

7. Surface Water Sampling Locations at the GJPO Facility $\ldots \ldots \ldots 27$

8. Geological Cross Section of the Alluvial Aquifer at the GJPO Facility . 40

9. Representative Stratigraphic Column at the GJPO Facility (compiled from well $\log$ GJ87-19) $\ldots \ldots \ldots \ldots \ldots \ldots \ldots \ldots 42$

10. Ground-Water Sampling Locations at the GJPO Facility . . . . . . 46

11. Concentrations of Ground-Water Analytes Exceeding Federal/State Standards in Alluvial Aquifer Well Samples at the GJPO . . . . . 48

12. Uranium Activities in Ground Water at the GJPO in March 1992 . . . 49

B-1. Uranium Concentrations in Ambient Air as a Percentage of the DCG at Station AIR-G-2 from January to December $19^{\prime}, 2 \ldots$ B-3

B-2. Thorium-230 Concentrations in Ambient Air as a Percentage of the DCG at Station AIR-G-2 from January to December 1992 . . . B-4

B-3. Radium-226 Concentrations in Ambient Air as a Percentage of the DCG at Station Air-G-2 from January to December 1992 . . . B-5

B-4. $\mathrm{PM}_{10}$ Concentrations in Ambient Air as a Percentage of the EPA/State Standard at Station AIR-G-2 . . . . . . . . B-6

B-5. Uranium Concentrations at the Upstream Gunnison River Sampling Location from January 1988 through December 1992 . . . B B-7

B-6. Uranium Concentrations at the On-Site Gunnison River Sampling Location from January 1988 through December 1992 . . . B B-8

B-7. Uranium Concentrations at the Downstream Gunnison River Sampling Location from January 1988 through December 1992 . . . . B-9

B-8. Uranium Concentrations in Well 10-19N from December 1986 through December 1992 
Figures (continued)

Page

B-9. Uranium Concentrations in Well 14-6NA from December 1986 through December 1992

B-10. Uranium Concentrations in Well GJ84-10 from December 1986 through December 1992

B-11. Molybdenum Concentrations in Well 10-19N from December 1986 through December 1992

B-12. Molybdenum Concentrations in Well 14-6NA from December 1986 through December 1992

B-13. Molybdenum Concentrations in Well GJ84-10 from December 1986 through December 1992

B-14. Arsenic Concentrations in Well 14-6NA from December 1986 through December 1992

B-15. Arsenic Concentrations in Well GJ84-10 from December 1986 through December 1992

B-16. Radium-226+228 Concentrations in Well 8-4S from June 1990 through December $1992 \ldots \ldots \ldots \ldots \ldots \ldots \ldots \ldots \ldots$ B-18

B-17. Radium-226 + 228 Concentrations in Well GJ84-10 from September 1987 through December 1992

B-18. Selenium Concentrations in Well 8-4S from December 1986 through December 1992

B-19. Selenium Concentrations in Well GJ84-10 from December 1986 through December 1992

C-1. Concentrations of Ground-Water Analytes Exceeding Federal/State Standards in Alluvial Aquifer Well Samples in March 1992

C-2. Concentrations of Ground-Water Analytes Exceeding Federal/State Standards in Alluvial Aquifer Well Samples in June 1992

C-3. Concentrations of Ground-Water Analytes Exceeding Federal/State Standards in Alluvial Aquifer Well Samples in September 1992 . . . .

C-4. Concentrations of Ground-Water Analytes Exceeding Federal/State Standards in Alluvial Aquifer Well Samples in December 1992 ..... 


\section{Tables}

Page

Table 1. Comparison of Average Annual Radon Concentrations At and Near the GJPO Facility with the DCG $\ldots \ldots \ldots \ldots \ldots \ldots \ldots \ldots$

2. Results of GJPO Air Particulate Monitoring Conducted during 1992 .. 19

3. Average Annual Gamma Exposure Rates At and Near the GJPO Facility during.1992

4. Comparison of 1992 and Historical Sewer Effluent Maximum Concentrations with Permitted Threshold Limits ...... . . 24

5. Comparison of State of Colorado Surface Water Quality Standards with 1992 and Historical Maximum Concentrations in the Gunnison



6. Effective Dose Equivalents Caused by Radiological Emissions from the GJPO Facility . . . . . . . . . . . . . . . . 34

7. Airborne Source Terms Used in the MICROAIRDOS ${ }^{\text {ma }}$ and AIRDOSPC $^{m}$ Models for the GJPO ............... 35

8. Comparison of Federal and State of Colorado Ground-Water Quality Standards with 1992 and Historical Maximum Concentrations in the Alluvial Aquifer $\ldots \ldots \ldots \ldots \ldots \ldots \ldots .4$

9. Summary of Analytical Results for the Interlaboratory Quality Assurance Programs .................... 53

A-1. Radon Data for Grand Junction, First Quarter $1992 \ldots \ldots \ldots \ldots$ A-3

A-2. Radon Data for Grand Junction, Second Quarter $1992 \ldots \ldots$. . . A A-4

A-3. Radon Data for Grand Junction, Third Quarter $1992 \ldots \ldots \ldots \ldots$. . . A-5

A-4. Radon Data for Grand Junction, Fourth Quarter $1992 \ldots \ldots \ldots$. . . A-6

A-5. Analytical Air Sample Results for Station AIR-G-1 during 1992 . . . . A-7

A-6. Analytical Air Sample Results for Station AIR-G-2 during 1992 . . . A-8

A-7. Analytical Air Sample Results for Station AIR-G-3 during 1992 . . . . A-9

A-8. Suspended Particulates $\left(\mathrm{PM}_{10}\right)$ Data for Station AIR-G-1 during 1992 
Tables (continued)

Page

A-9. Suspended Particulates $\left(\mathrm{PM}_{10}\right)$ Data for Station AIR-G-2

during 1992

A-10. Suspended Particulates $\left(\mathbf{P M}_{10}\right)$ Data for Station AIR-G-3



A-11. Environmental Radiation Exposure Data for Grand Junction, First Quarter 1992

A-12. Environmental Radiation Exposure Data for Grand Junction, Second Quarter $1992 \ldots \ldots \ldots \ldots \ldots \ldots \ldots \ldots \ldots \ldots$. . . . . . . . . . . . .

A-13. Environmental Radiation Exposure Data for Grand Junction, Third Quarter 1992

A-14. Envirormental Radiation Exposure Data for Grand Junction, Fourth Quarter 1992

A-15. Meteorological Data for Grand Junction .............. A-19

A-16. Sewer Effluent Chemistry Data for Grand Junction during 1992 . . . A-21

A-17. Sewer Effluent Chemistry Data for Grand Junction during 1992, Organics

A-18. Water Chemistry Data for Grand Junction, March 16 through March 18, 1992 .

A-19. Water Chemistry Data for Grand Junction, June 15 through June 19, 1992

A-20. Water Chemistry Data for Grand Junction, September 8 through September 14, 1992

A-21. Water Chemistry Data for Grand Junction, December 14 through December 18, 1992

A-22. Target Compound List of Organic Constituents Included in Analysis of Ground Water at the GJPO

A-23. Organic Constituents Observed in Samples Collected from Ground Water at the GJPO, March 16 through March 18, $1992 \ldots$. . .

A-24. Organic Constituents Observed in Samples Collected from Ground Water at the GJPO, September 8 through September 14, 1992 


\section{Abbreviations and Acronyms}

\begin{tabular}{ll} 
Alky & Alkalinity \\
BOD & Biochemical oxygen demand \\
CDH & Colorado Department of Health \\
CDT & Specific conductance \\
CERCLA & Comprehensive Environmental Response, Compensation, and \\
& Liability Act \\
CESQG & Conditionally Exempt Small Quantity Generator \\
Ci/yr & Curies per year \\
CFR & Code of Federal Regulations \\
COD & Chemical oxygen demand \\
COE & U.S. Army Corps of Engineers \\
CWIP & Commingled Waste Investigation Project \\
DCG & Derived Concentration Guide \\
DOE & U.S. Department of Energy \\
DOE-AL & DOE Albuquerque Field Office \\
DOE-HQ & DOE Headquarters \\
EA & Environmental Assessment \\
EDE & Effective dose equivalent \\
EML & Environmental Measurements Laboratory \\
EMSL & Environmental Measurement Systems Laboratory \\
EPA & U.S. Environmental Protection Agency \\
g/F & Grams per filter \\
gal/yr & Gallons per year \\
GJPO & Grand Junction Projects Office \\
GJPORAP & Grand Junction Projects Office Remedial Action Project \\
mg/L & Milligrams per liter \\
mrem & Millirems \\
mrem/yr & Millirems per year \\
NEPA & National Environmental Policy Act of 1969 \\
NESHAP & National Emission Standards for Hazardous Air Pollutants \\
NPDES & National Pollutant Discharge Elimination System \\
ORNL & C ak Ridge National Laboratory \\
PCB & Polychlorinated biphenyl \\
pCi/F & Picocuries per filter \\
pCi/L & Picocuries per liter \\
pCi/ $/ \mu$ g & Picocuries per microgram \\
pg/mL & Picograms per milliliter \\
PM 10 & Particulate matter less than or equal to 10 micrometers in diameter \\
ppm & Parts per million \\
QA & Quality assurance \\
QAPP & Quality Assurance Program Plan \\
QC & Quality control \\
RCRA & Resource Conservation and Recovery Act \\
RI/FS & Remedial Investigation/Feasibility Study \\
RRM & Residual radioactive material \\
& \\
\hline
\end{tabular}


Abbreviations and Acronyms (Continued)

$\begin{array}{ll}\text { SARA } & \text { Superfund Amendments and Reauthorization Act } \\ \text { scfm } & \text { Standard cubic feet per minute } \\ \text { SEN } & \text { Secretary of Energy Notice } \\ \text { TCL } & \text { Target Compound List } \\ \text { TDS } & \text { Total dissolved solids } \\ \text { TLD } & \text { Thermoluminescent dosimeter } \\ \text { TOC } & \text { Total organic carbon } \\ \text { tons } / \mathrm{yr} & \text { Tons per year } \\ \text { TSCA } & \text { Toxic Substances Control Act } \\ \text { TSS } & \text { Total suspended solids } \\ \mu \mathrm{Ci} / \mathrm{L} & \text { Microcuries per liter } \\ \mu \mathrm{Ci} / \mathrm{mL} & \text { Microcuries per milliliter } \\ \mu \mathrm{Ci} / \mathrm{yr} & \text { Microcuries per year } \\ \mu \mathrm{g} / \mathrm{F} & \text { Micrograms per filter } \\ \mu \mathrm{g} / \mathrm{L} & \text { Micrograms per liter } \\ \mu \mathrm{g} / \mathrm{m}^{3} & \text { Micrograms per cubic meter } \\ \mu \mathrm{m} & \text { Micrometers } \\ \mu \mathrm{mhos} / \mathrm{cm} & \text { Micromhos per centimeter } \\ \mathrm{UMTRCA} & \text { Uranium Mill Tailings Radiation Control Act }\end{array}$




\section{Executive Summary}

This report presents information pertaining to environmental activities conducted during calendar year 1992 at the U.S. Department of Energy Grand Junction Projects Office (DOE-GJPO) facility in Colorado. It has been prepared in accordance with the requirements of DOE Order 5400.1 and with supplemental guidance from the DOE Headquarters. Monitoring and report preparation were performed by RUST Geotech Inc. (Geotech), the prime contractor for the DOE-GJPO facility.

Environmental activities conducted at the GJPO facility during 1992 included those associated with environmental compliance, site remediation, off-site dose modeling, and radiological and nonradiological monitoring.

Three significant issues associated with environmental compliance emerged during 1992. The first issue emerged in February when the DOE-GJPO's waste generator status changed from that of a small quantity generator to a conditionally exempt small quantity generator (CESQG). By maintaining status as a CESQG, the GJPO will be exempt from the land disposal restrictions and associated restricted-waste storage prohibitions under the Resource Conservation and Recovery Act.

The second issue was concerned with the generation of mixed wastes on the facility, which was curtailed on May 8 because of the expiration of the Two-Year National Capacity Variance for Mixed Waste. Following approval of several hazardous waste compliance position documents, the CESQG Management Plan (Chem-Nuclear Geotech, Inc. 1992a) was prepared, and mixed-waste generation was resumed in on-site laboratories on November 30, 1992.

The third issue ernerged on December 31 when the U. S. Environmental Protection Agency (EPA), Region VIII, served the DOE-GJPO with a Notice of Noncompliance, Compliance Schedule, and Notice of Opportunity for Conference and served Geotech with a Complaint and Notice of Opportunity for Hearing. Both servings identified two çounts associated with the improper placement and storage of polychlorinated biphenylcontaminated uranium mill tailings in an on-site stockpile. An informal settlement conference with EPA on March 16, 1993, resulted in the penalty associated with Count I being reduced and Count II and its associated penalty being dismissed. No terms or conditions for a consent agreement were reached in the informal settlement conference.

Four phases of the on-site Grand Junction Projects Office Remedial Action Project were completed in 1992. Remediation activities, which included the removal of 161,589 tons of uranium-mill-tailings-contaminated material from the facility, were conducted in compliance with all applicable permits.

Off-site dose modeling for the GJPO was conducted to determine compliance with current National Emission Standards for Hazardous Air Pollutants, Subpart $\mathrm{H}$, and applicable DOE Orders (5400.1 and 5400.5). Results of the modeling indicated an 
effective dose equivalent (EDE) from airborne radioparticulates of $5.710 \times 10^{-2}$ millirems per year (mrem/yr). This dose was derived from summing the doses caused by all air emission sources on the facility. Air emission sources included three point sources and one area source. The EPA standard for such emissions is $10 \mathrm{mrem} / \mathrm{yr}$. The collective effective dose (population dose), including the radon source term, was calculated as $9.508 \times 10^{-3}$ person-rem per year. No standard is associated with this latter dose. The total off-site EDE to the public from all sources of radiation emanating from the facility (radon, air particulates, gamma) was calculated as $9 \mathrm{mrem} / \mathrm{yr}$, which is well below the DOE dose limit of $100 \mathrm{mrem} / \mathrm{yr}$ above background.

The radiological and nonradiological monitoring program at the GJPO facility included monitoring of activities that generate potentially hazardous or toxic wastes and monitoring of ambient air, surface water, and ground water. Pathways of potential contaminant migration off site consist of atmospheric transport, wastewater dischargeinto the municipal sewer system, and ground-water discharge of the alluvial aquifer subjacent to the facility. Operational wastes include sanitary effluent that is discharged into the city of Grand Junction/Mesa County sewer system and hazardous wastes that are stored and disposed of in accordance with the Resource Conservation and Recovery Act. The total quantity of radioactivity released as airborne effluent from the GJPO during 1992 was estimated to be $3.61 \times 10^{-5}$ curies; the quantity released as liquid (sewer) effluent was estimated to be $2.008 \times 10^{-5}$ curies.

The ambient air monitoring program included measurements of atmospheric radon, particulate matter (radiological and nonradiological constituents), and gamma radiation. Atmospheric radon concentrations were measured at 13 site-boundary and off-site locations. No measured radon concentration exceeded the derived concentration guide for radon specified by DOE Order 5400.5 ( $3 \times 10^{-9}$ microcuries per milliliter above background) during 1992.

Air particulate monitoring was conducted at three on-site locations with high-volume air particulate samplers. Maximum airborne concentrations of radium-226, thorium-230, and uranium were all several orders of magnitude below the regulatory guidelines specified by DOE Order 5400.5. EPA particulate matter $\left(\mathrm{PM}_{10}\right)$ standards of 50 micrograms per cubic meter $\left(\mu \mathrm{g} / \mathrm{m}^{3}\right)\left(\right.$ annual arithmetic mean) and $150 \mu \mathrm{g} / \mathrm{m}^{3}$ (24-hour average) also were not exceeded at any location.

Gamma radiation was monitored at nine on-site and six off-site locations. All monitoring locations yielded gamma radiation levels well below the DOE standard of $100 \mathrm{mrem} / \mathrm{yr}$ (above background).

Radiological and nonradiological constituents were monitored in surface waters on the GJPO facility. Surface-water sources sampled in 1992 included the liquid effluent in the underground sewer system, the North and South Ponds on the facility, and the Gunnison River flowing adjacent to the facility. Samples were drawn from the sewer effluent to ensure compliance with the city of Grand Junction's Industrial Pretreatment Permit. Measured analyte concentrations were below threshold concentrations established by the permit, with the exception of those for biochemical oxygen demand and total suspended 
solids, which exceeded threshold limits during the December sampling event. The cause of the excessive concentrations was investigated and corrected immediately.

Analysis of samples collected from the North and South Ponds indicated the presence of uranium, vanadium, arsenic, molybdenum, and sulfate in higher-than-background concentrations. These analytes are associated with leachate from uranium mill tailings.

Within the Gunnison River, which flows adjacent to the GJPO facility, state water quality standards for sulfate and manganese were exceeded during 1992. Because these excessive concentrations consistently occurred upstream as well as downstream of the GJPO facility in 1992 as well as in past years, they are not believed to be related to existing ground-water contamination or activities occurring at the GJPO facility.

Ground-water monitoring included sampling the shallow alluvial aquifer underlying the GJPO facility. Analytical results showed that arsenic, lead, total dissolved solids, selenium, molybdenum, nitrate, gross alpha, and uranium-234 and -238 are contaminating the ground water. All of these analyte concentrations exceeded standards established by the Uranium Mill Tailings Radiation Control Act and the Colorado Water Quality Control Commission in one or more wells during 1992. These excessive concentrations are consistent with previous years' monitoring results. 


\section{Introduction}

The U.S. Department of Energy Grand Junction Projects Office (DOE-GJPO) facility is located in Mesa County, Colorado, immediately south and west of the Grand Junction city limits (Figure 1). Lying within an accretionary bend of the Gunnison River, the facility occupies an elongated, north-south-trending tract of 22.8 hectares (56.4 acres) that is bounded on the west and south by the river and on the north and east by county, city, and private property. An earthen dike runs between the facility and the river to the west. The Gunnison River, which converges with the Colorado River about 0.8 kilometer ( 0.5 mile) downstream of the facility, is used for seasonal recreational activities such as boating, fishing, and swimming. All domestic surface-water sources for the Grand Junction area are located upgradient of the GJPO facility.

In the immediate vicinity of the facility, the river canyon is 455 to 610 meters $(1,500$ to 2,000 feet) wide and 18 to 49 meters (60 to $160 \mathrm{feet}$ ) deep and is incised into the variegated siltstones, mudstones, and shales of the Brushy Basin Member of the Morrison Formation. Beneath the facility is a fine sandy soil, several inches to several feet thick, which is underlain by 6 to 12 meters (20 to 40 feet) of quaternary alluvium composed of silty sands and sandy gravels. The ground water contained within the alluvial aquifer has been contaminated by the leached products of uranium mill tailings. Water from the aquifer is not used for any purpose.

Although immediately surrounded by agricultural lands, the facility lies within 1 kilometer ( 0.6 mile) of more densely populated areas of Grand Junction. The 1990 population of the city of Grand Junction and surrounding areas was approximately 85,000 .

Personnel at the facility develop, support, and administer a variety of programs. Historically, personnel were mainly involved in uranium procurement, evaluation of domestic uranium resources, development of uranium extractive processes, and advancement of geologic and geophysical exploration techniques. The current scope of activities includes provision of considerable support to the federal government's various remedial action programs. Housed on the facility are fully equipped laboratories for analytical chemistry, mineralogy/petrology, radon, and electronics. Research groups at the facility have received funding for specific projects from various entities, including the U.S. Environmental Protection Agency (EPA), U.S. Department of Defense, and DOE in conjunction with several universities.

Uranium milling, analyses, and storage were conducted on the facility for a period of approximately 30 years, but these activities ceased in the mid-1970s. All known contamination is believed to be the result of these past activities. According to historical records (those maintained by DOE and its predecessor agencies, the U.S. Atomic Energy Commission and the U.S. Energy Research and Development Administration), approximately 29,024 metric tons (32,000 short tons) of ore was processed between 1943 and 1958. The resulting tailings consisted of approximately 136,100 cubic meters (178,000 cubic yards) of material that was distributed throughout the site, as shown in 


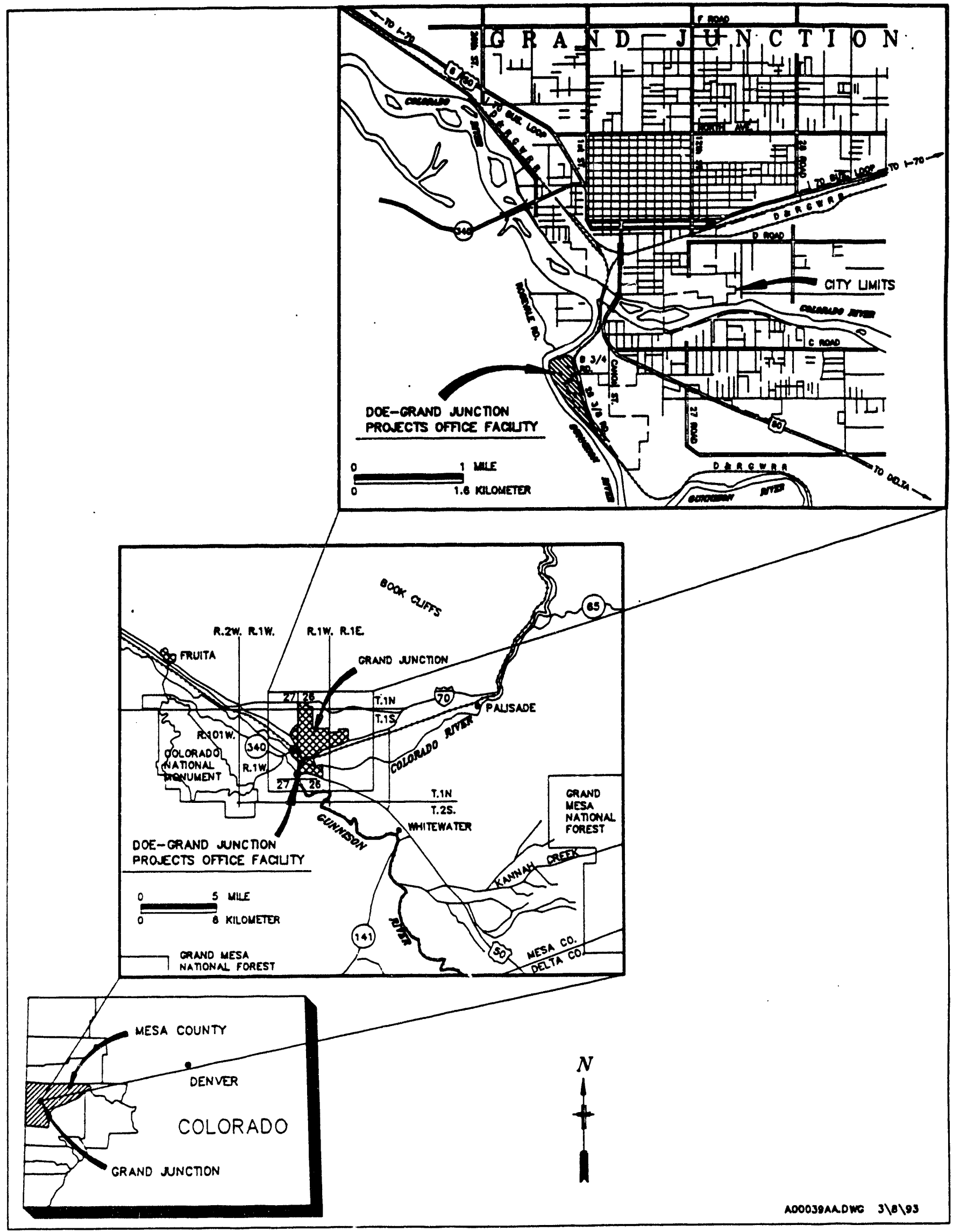

Figure 1. Site Location Map of the GJPO 
Figure 2. Site investigations formally began in 1984 when the GJPO facility was accepted into the DOE Surplus Facilities Management Program. The facility was later transferred to the Defense Decontamination and Decommissioning Program. Under the guidelines set forth in the Uranium Mill Tailings Radiation Control Act (UMTRCA), site characterization and remedial action studies were initiated to assess the radiological hazards at the facility. The results of these studies are presented in a radiological characterization by Henwood and Ridolfi (1980). With the passage of the Superfund Amendments and Reauthorization Act (SARA) by Congress in October 1986, DOE-GJPO elected to comply with the Comprehensive Environmental Response, Compensation, and Liability Act (CERCLA) process as well as the National Environmental Policy Act (NEPA) process. A Final Remedial Investigation/Feasibility Study-Environmental Assessment (RI/FS-EA) was completed in 1989 (UNC Geotech 1989).

This Site Environmental Report presents information pertaining to environmental activities conducted during calendar year 1992 at the DOE-GJPO facility. It has been prepared by RUST Geotech Inc. (Geotech), the prime contractor for the DOE-GJPO.

The report is organized into nine major sections: Compliance SummaryJanuary 1, 1992, through April 1, 1993; Environmental Program Information; Environmental Radiological Program Information; Environmental Nonradiological Program Information; Ground-Water Protection Program; Quality Assurance; Appendix A, Monitoring Data; Appendix B, Time-Concentration Graphs; and Appendix C, Well Location Maps Showing Ground-Water Analytes that Exceed Federal/State Standards.

The Compliance Summary section summarizes the GJPO's compliance with federal, state, and local environmental requirements at the facility for the period January 1, 1992, through April 1, 1993. It also includes descriptions of the facility's Pollution Prevention and Waste Management programs and a list of environmental permits issued to the GJPO by federal, state, and local regulatory agencies.

The Environmental Program Information section includes (1) a description of the contamination present at the site, (2) a summary of air and surface-water monitoring performed on and near the site, including a discussion of how monitoring results compare with applicable standards, (3) a list of environmental documents completed in 1992 perta ing to site activities, and (4) a summary of significant environmental activities occurring at the site.

The third and fourth sections, Environmental Radiological and Environmental Nonradiological Program Information, summarize the monitoring results from the Environmental Program Information section in terms of radiological and nonradiological monitoring, respectively. The former section also includes calculations of off-site dose.

In the Ground-Water Protection Program section, the hydrogeology at the GJPO facility and the program col aucted to monitor ground water are described. Analytical results of ground-water monitoring are compared with federal and state standards, and diagrams showing contaminant concentrations within ground water are presented. 


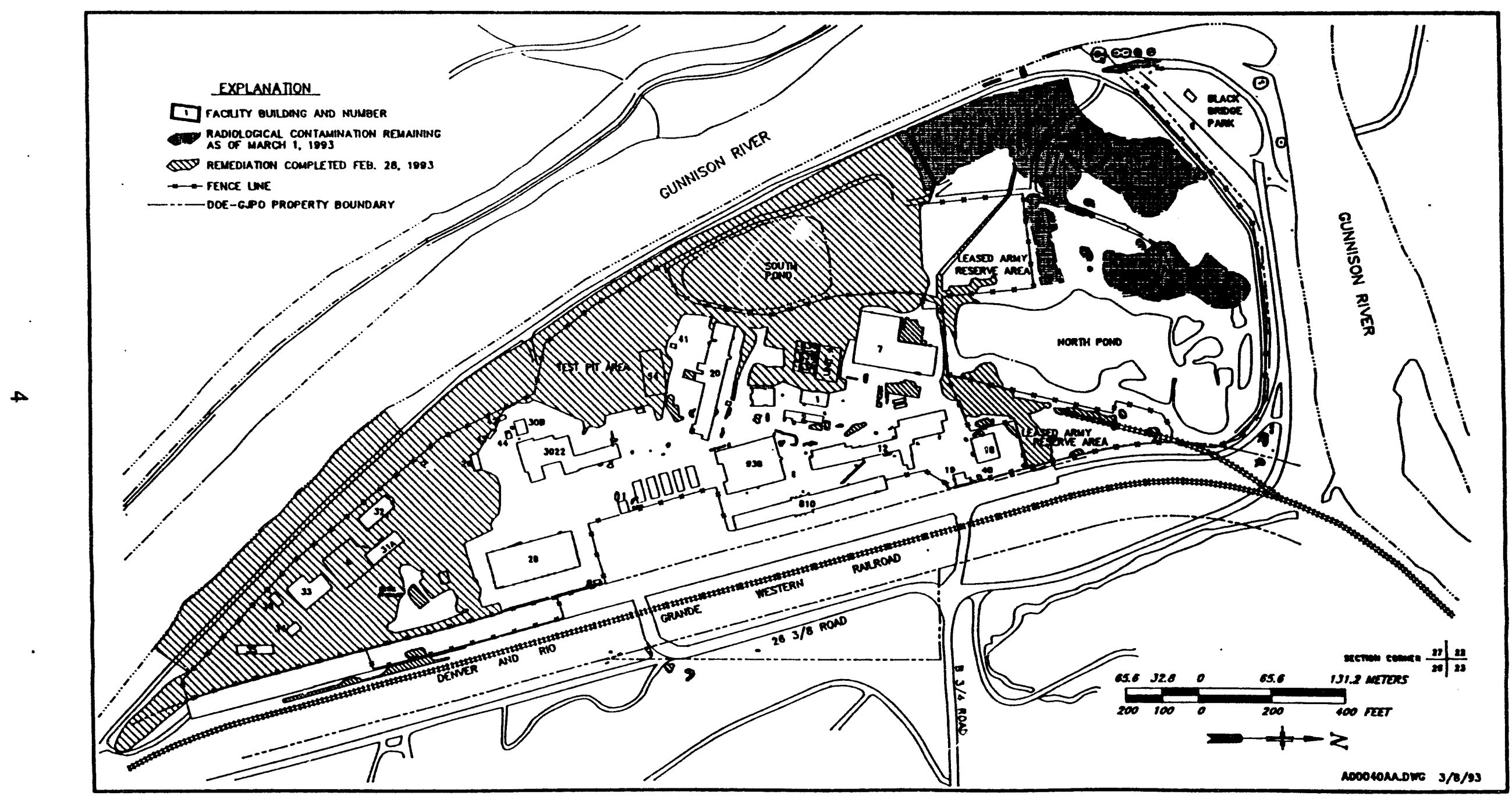

Figure 2. Map of the GJPO Facility Showing Areas of Tailings Contamination and Remediation 
The Quality Assurance section summarizes the measures taken to ensure the quality of monitoring data collected at and near the GJPO facility. This section also includes results of the participation of the on-site Analytical Chemistry Laboratory in interlaboratory cross-check programs.

Appendix A comprises analytical data collected during 1992 and is organized according to medium (air, sewer, and water) and date sampled. Analytical data include radon, air particulates, direct gamma radiation, meteorology, sewer effluent, surface water, and ground water.

In Appendix B, data from selected.media and locations are presented graphically to show changes in analyte concentrations over time. Also included in the graphs is a comparison between collected data and the applicable local, state, or federal standard.

In Appendix C, maps of alluvial well locations identify which ground-water analytes exceeded their respective federal/state standards at each well. Results of each of the 1992 quarterly sampling events are presented.

This report includes an Abbreviations and Acronyms section, which follows the Table of Contents; a References section, which follows the Quality Assurance section; and a Distribution List section, which lists persons and organizations who receive copies of this report. 


\section{Compliance Summary - January 1, 1992, Through April 1, 1993}

\section{Compliance Status}

Compliance status for each of the major environmental statutes applicaible to the DOE-GJPO facility is as follows:

\section{Comprehensive Environmental Response, Compensation, and Liability Act}

Although the DOE-GJPO facility was not listed on the National Priorities List by the EPA, DOE-GJPO elected to follow the CERCLA process for environmental cleanup of the facility. The Grand Junction Projects Office Remedial Action Project (GJPORAP) was begun to remove residual radioactive materials (RRM) remaining on site from early operations. An RI/FS-EA was completed in 1989, and a Record of Decision regarding the planned action was finalized and approved by the DOE Idaho Field Office in April 1990. Phase IV of the remedial action, which involved removal of RRM from the South Pond area, was completed in August 1992. Phases II, III, IC, ID, and V of the remedial action, which included demolition of Buildings 6 and 31 and removal of exterior RRM from areas west and southwest of the GJPO facility and adjacent to Building 7, were completed in November 1992. Ongoing remedial action (Phase IVA) includes removal of RRM from the northwest dike, the water line area by the North Parking Lot, Treasure Island, Black Bridge Park, and an area east of Building 7.

Updates to the GJPORAP Information Repository, a CERCLA-required project file that contains documentation of site activities, were prepared in October and December 1992.

A self-assessment of the DOE-GJPO's management of substances regulated by SARA, Title III, is being conducted and is anticipated to be completed in 1993.

\section{Clean Air Act}

In response to Air Pollution Emissions Notifications submitted to the state of Colorado during 1990, four emission permits were granted initial approval by the Air Pollution Control Division. Colorado Department of Health (CDH), on September 30, 1991, for air emission sources on the facility. The Analytical Chemistry Laboratory's emissions are permitted under Emission Permit No. 90ME402-1; the Sample Preparation Facility's emissions are permitted under Emission Permit No. 90ME402-2; the facility boilers emissions are permitted under Emission Permit No. 90ME402-3; and emissions from the Petrology Laboratory, the blueprint machine in Building 938, and the paint booth and degreasing unit in Building 28 are covered by Emission Permit No. 90ME402-4. The state of Colorado is expected to grant final approval for these emission permits in April 1993. Each permit will then require annual renewal. 
Off-site dose modeling was conducted for the facility to determine compliance with current National Emission Standards for Hazardous Air Pollutants (NESHAP), Subpart H, and DOE Orders 5400.1 and 5400.5. The off-site dose resulting from 1992 emissions was $5.710 \times 10^{-2}$ millirems per year (mrem/yr). The EPA standard for such emissions is $10 \mathrm{mrem} / \mathrm{yr}$.

Monthly remediation progress reports were submitted to tie EPA in compliance with an agreement (dated October 29, 1991) made with that agency concerning NESHAP, Subpart Q, Radon Emission Requirements.

During the week of August 3, 1992, the DOE Albuquerque Field Office (DOE-AL) conducted an appraisal of environmental, health, and quality compliance at the DOE-GJPO. One of the observations resulting from this appraisal pertained to Air Quality Permit No. 89ME080-2F, which had been issued to the DOE-GJPO by the CDH for mill tailings deposition at the state-owned repository. The observation noted that the DOE-GJPO had not requested the CDH to rescind this permit, even though the responsibilities for operating the state-owned repository had been transferred to another contractor in July 1991. A request for cancellation of the permit was submitted to the Air Pollution Control Division, CDH, on December 15, 1992. As of April 1, 1993, no response to this request had been received.

\section{Clean Water Act}

The DOE-GJPO does not discharge any wastewater or storm water via a point source to "waters of the United States." The facility, therefore, is exempt from the National Pollutant Discharge Elimination System (NPDES) permitting requirements, as specified in Section 402 of the Clean Water Act. In a letter dated July 28, 1992, the EPA, Region VIII, determined that the types of storm-water runoff existing at the facility (e.g., runoff from employee parking lots and administrative buildings, sheet now, etc.) do not require an NPDES storm-water permit. No other NPDES-regulated wastewater discharges from the DOE-GJPO facility are known to exist.

Domestic sewage effluent from the facility is routed to the publicly owned treatment works operated by the city of Grand Junction. Sewage effluent was sampled monthly to ensure compliance with the Class II, Industrial Pretreatment Permit (No. 0023), which was issued in March 1989 and revised in April 1992. In accordance with the permit, monitoring reports were submitted to the city of Grand Junction in January and July 1992. Another revision to the permit (No. 23REV), which requires more frequent sampling of the effluent but for a fewer number of analytes, was received from the city's Industrial Pretreatment Program Coordinator in February 1993.

During 1992, all constituent concentrations measured within sewer effluent were below their respective threshold limits established by the permit, with the exception of those for biochemical oxygen demand (BOD) and total suspended solids (TSS). Concentrations of these constituents exceeded threshold limits during the December sampling. These results were reported immediately to the city of Grand Junction, and a resampling was begun. During resampling, the cause for the excessive levels was discovered (electrical 
cables within the sampling area had dislodged and had trapped solid debris at the sampling site-see Sewer Effluent subsection of this report for details) and corrected.

On February 16, 1993, a sewer effluent grab sample was collected at the north lift station by the city of Grand Junction, as part of its permit oversight program. The $\mathrm{pH}$ of this sample was 4.29 , which exceeded the maximum discharge range of 5.5 to 9.5 for $\mathrm{pH}$. This was the first time, since issuance of the permit in March 1989, that pH was found to be outside the acceptable range by either the city or the GJPO. Upon learning of the low $\mathrm{pH}$ measurements, the on-site Analytical Chemistry Laboratory immediately initiated procedures to neutralize all acid solutions prior to their discharge to the sewer system. The sewer effluent at the site was resampled the next day, and measured $\mathrm{pH}$ levels $(7.36,7.27,8.46,8.28)$ were found to be well within discharge limits.

In accordance with Section 404 of the Clean Water Act, a 404 Permit (Permit No. 10040) was obtained from the U.S. Army Corps of Engineers (COE) in 1989 for excavation of RRM from the facility dike and adjacent areas along the Gunnison River. An extension of the 404 Permit was requested during 1991 and was received on February 25, 1992. The permit is valid through November 1993.

\section{Executive Order 11988 "Floodplain Management"}

The Mesa County Housing and Urban Design Flood Insurance Rate Map (July 1978) places the GJPO facility within the 1,000-year floodplain. In accordance with Executive Order 11988, "Floodplain Management," a Floodplain Management Plan was prepared and a Mesa County Floodplain Development Permit was obtained for the facility and GJPORAP operations.

\section{Resource Conservation and Recovery Act}

On March 29, 1991, the DOE-GJPO's waste generator status changed from a conditionally exempt small quantity generator (CESQG) of hazardous waste to a small quantity generator. This change resulted from the generation within a single month of approximately 408 kilograms of mixed waste that was discovered during on-site remedial action. Generation of this waste also resulted in the DOE-GJPO surpassing the amount of accumulated hazardous and mixed waste allowed under CESQG status $(1,000$ kilograms). In February 1992, status was returned to a CESQG after the following criteria were met: (1) a Part A permit application was submitted ou January 22, 1992, to the $\mathrm{CDH}$ and EPA (submission of the application officially commenced operations within the hazardous and mixed waste storage unit [i.e., Building 42] as a Resource Conservation and Recovery Act [RCRA] interim-status storage facility); (2) less than 1,000 kilograms of hazardous and mixed waste was in on-site accumulation; and (3) less than 100 kilograms of hazardous and mixed waste was generated per month.

During 1992, approximately 595 kilograms of hazardous and mixed wastes was generated from routine facility operations. Points of generation included Laboratory Services, Maintenance, Information Services, Engineering, and Records Management. The 
decrease in genera tion rates from the previous year resulted from the implementation of waste minimization efforts and a temporary curtailment of certain laboratory operations from May to December 1992. The icmporary curtailment of laboratory operations, which included a complete cessation of mixed-waste generation, occurred because of the expiration on May 8, 1992, of the Two-Year National Capacity Variance for Mixed Waste. In response to that event, four hazardous waste compliance position documents were written, addressing

- Ignitability, flammability, and combustibility of solid waste samples;

- Management of analytical excess samples;

- Receipt of off-site hazardous waste at the DOE-GJPO interim status facility; and

- Management of land-disposal-restricted mixed waste generated at the DOE-GJPO.

Copies of the documents were provided to the EPA, Region VIII; the CDH; and the DOE-AL Environmental Protection Division. Following approval of the four position papers by each of these agencies, the DOE-GJPO prepared the CESQG Management Plan (Chem-Nuclear Geotech, Inc. 1992a), and on November 30, 1992, allowed the resumption of mixed-waste generation in on-site laboratories in accordance with the plan.

\section{National Environmental Policy Act}

In June 1992, the Final Draft Environmental Assessment of Facility Operations at the Grand Junction Projects Office (Chem-Nuclear Geotech, Inc. 1992b) was approved by the DOE-AL and, in July, was submitted to DOE-Headquarters (DOE-HQ) for review. In January 1993, the DOE-GJPO was requested by DOE-HQ (EM-40) to revise and update the EA to reflect conditions on the facility as of June 1993.

The DOE-GJPO met with DOE-AL NEPA staff in April 1992 as part of the DOE-GJPO's transition to the DOE-AL. At that time, DOE-AL's Supplemental Directive (5440.1D) was obtained for implementation at the DOE-GJPO. In August 1992, new policy and procedures referring to the Supplemental Directive and Secretary of Energy Notice (SEN) 15-90 were incorporated into the Environmental Protection Manual (Chem Nuclear-Geotech, Inc. 1992c).

As of April 1, 1993, 40 NEPA Categorical Exclusions and 12 NEPA Administrative Records were completed or initiated. An in-house central record-keeping system that documents and tracks NEPA determinations and the status of NEPA reviews and approvals was established in November 1992 and is updated monthly. Monthly reports listing active EAs and Environmental Impact Statements were prepared in accordance with SEN 15-90 and submitted to the DOE-AL. 


\section{Toxic Substance Control Act}

Radioactive uranium mill tailings unknowingly mixed with polychlorinated biphenyls (PCBs) were placed in the on-site temporary tailings stockpile in summer 1989. The total volume of this commingled waste, before placement in the stockpile, was less than 1 cubic meter; the concentration of PCBs in the waste (before placement) ranged from 110 to 920 parts. per million. Under EPA guidance, the PCB-contaminated tailings were excavated and stored at the facility in steel roll-off containers.

On December 31, 1992, the EPA, Region VIII, served the DOE-GJPO with a Notice of Noncompliance, Compliance Schedule, and Notice of Opportunity for Conference. The EPA also served Geotech with a Complaint and Notice of Opportunity for Hearing. Both servings identified two counts. Count I identified the placement of PCBcontaminated tailings in the stockpile as improper storage for disposal of PCBs in violation of 40 CFR 761.65(b). Count II identified storage of the PCB-contaminated tailings in the stockpile from summer 1989 to August 1991 as exceeding the 1-year limit established at 40 CFR 761.65(a).

On March 16, 1993, Geotech held an informal settlement conference with EPA. As a result of that conference, the penalty associated with Count I was reduced by 40 percent because of Geotech's volytary notification of the incident and desire to comply with Toxic Substances Control Act (TSCA) regulations. Count II and its associated penalty were dismissed because of Geotech's inability to comply with the 1-year storage limit; i.e., no facility able to treat both components of the commingled waste (PCBs and uranium mill tailings) was available. No terms or conditions for a consent agreement were reached in the inforinal settlement conference.

PCB wastes generated by the Analytical Chemistry Laboratory during 1992 were managed and stored in accordance with applicable regulations, with the exception of the TSCA 1-year storage limitation. Liquid PCB wastes are awaiting off-site disposal pending approval of The Application to Qualify Hazardous Wastes as Nonradioactive for Off-Site Shipment for Purposes of Regulatory Compliance and Safety (i.e., the case-by-case exemption) and the Performance Objective for Certification of Nonradioactive Hazardous Waste, which address the DOE-HQ waste shipment moratorium (see Waste Management subsection under Current Issues and Actions). Solid PCB wastes generated by the Analytical Chemistry Laboratory, which include uranium mill tailings that have undergone analysis for PCBs/pesticides, are included in the DOE-GJPO's 180-day mixed waste inventory and treatment capacities report. Using information provided in this report, a site treatment plan will be developed and will delineate available options for treating these wastes.

Between the months of May 1992 and April 1993, asbestos abatement actions were completed in Buildings 12, 20, and 3022 in compliance with local, state, and federal regulations.

During the August 1992 appraisal of environmental, health, and quality compliance at the DOE-GJPO, the DOE-AL issued a finding that addressed the absence of an asbestos management plan. This finding was resolved in December 1992 when a policy 
establishing minimum requirements (in accordance with TSCA, state, and local regulations) for conducting asbestos renovation or demolition at the facility was incorporated into the Environmental Protection Manual (Chem-Nuclear Geotech, Inc. 1992c).

\section{Current Issues and Actions}

\section{DOE-HQ Baseline Environmental Audit}

A baseline environmental audit conducted at the DOE-GJPO facility by the DOE-HQ in May and June 1991 resulted in the identification of 48 compliance and best-management-practice findings. The findings, which are summarized in the Environmental Audit of the Grand Junction Projects Office (DOE 1991a), were subdivided into 316 action items requiring completion or resolution to achieve compliance. A corrective action plan to address these deficiencies, the Grand Junction Projects Office U.S. Department of Energy Baseline Environmental Audit Action Plan (Chem-Nuclear Geotech, Inc. 1992d), was completed by the DOE-GJPO on January 21, 1992. As of April 1, 1993, approximately 95 percent of the action items had been completed.

The audit team recognized DOE-GJPO's system for ground-water well record organization and retention as a noteworthy practice. The entire history of each well on the facility, including records of the well permit, well construction details, and monitoring data, is contained in one file. This system allows quick and easy access to well information.

\section{Pollution Prevention Awareness Program}

In accordance with DOE Order 5400.1, the Pollution Prevention Awareness Program was implemented in March 1992 with the issuance of the Waste Minimization and Pollution Prevention Awareness Plan (Chem-Nuclear Geotech, Inc. 1992e). Discussed in the plan are the basic components of a pollution prevention awareness program, which include employee awareness, training, incentives, and awards.

\section{Waste Management}

Small quantities of low-level radioactive, mixed, and hazardous wastes were generated at the DOE-GJPO facility during 1992 in support of a variety of research and environmental restoration programs. These wastes were managed according to Colorado Hazardous Waste Regulations and DOE Orders 5400.3, Hazardous and Radioactive Waste Program, and 5820.2A, Radioactive Waste Management.

During 1992, hazardous wastes originated from a variety of on-site sources, including Information Services, Engineering, the Boiler Plant, and various maintenance and laboratory operations. Low-level and mixed wastes originated primarily from the Analytical Chemistry Laboratory as sample residue, sample extractant, and unused or 
unusable radiochemicals. Because of the DOE-GJPO dependence upon off-site treatment and disposal facilities, a key element of the waste management program was the implementation of an aggressive waste minimization program. DOE-GJPO's Waste Minimization and Pollution Prevention Awareness Plan (Chem-Nuclear Geotech, Inc. 1992e) was updated and reissued in March 1992.

As a result of the DOE-HQ waste shipment moratorium, The Application to Qualify Hazardous Wastes as Nonradioactive for Off-Site Shipment for Purposes of Regulatory Compliance and Safety and the Performance Objective for Certification of Nonradioactive Hazardous Waste were prepared and submitted to the DOE-HQ in October 1992 and January 1993, respectively. These documents discuss the procedures by which hazardous wastes shipped off site will be verified as nonradioactive.

The CESQG Management Plan (Chem-Nuclear Geotech, Inc. 1992a) was completed in November 1992. This plan establishes the process by which hazardous and mixed waste generated at the facility will be managed to maintain the GJPO's status as a CESQG. By maintaining status as a CESQG, the GJPO will be exempt from the land disposal restrictions and associated restricted-waste storage prohibitions under RCRA. CESQG status also will allow the GJPO to generate mixed wastes, even though treatment technology and capacity have not been identified.

\section{Summary of Facility Permits}

DOE-GJPO facility permits that were active during the 1992 calendar year include

- Forty-seven well permits (Permit Nos. 039687 to 039733) issued by the Colorado Division of Water Resources for GJPO monitoring wells in September 1991 and one permit issued in September of 1992 (No. 166057). Well permits regulate the installation and abandonment of monitoring wells. Water-level measurements and water quality analyses are submitted to the Division of Water Resources upon request.

- A gravel pit permit (Permit No. 037845-F) issued in 1990 by the Colorado Division of Water Resources. Required if excavation activities expose ground water, this permit is valid until remedial work at the DOE-GJPO facility is complete.

- A State of Colorado Section 401 Water Quality Certification (No. 2030) issued to the DOE-GJPO facility in 1988 by the CDH to control erosion and sedimentation of the Gunnison River resulting from excavation activities associated with radioactive tailings removal and transportation. This certification is valid until remedial work at the facility is complete.

- A Mesa County floodplain development permit (Permit No. F-1-90) reissued in 1990 by the Mesa County Engineering Department. This permit allows for reconstruction of the flood control dike along the Gunnison River and is valid through completion of remedial work. 
- An industrial pretreatment permit (No. 0023), issued by the city of Grand Junction for discharging sewer effluent to the city's wastewater treatment plant. The permit is valid through May 1996.

- A 404 permit obtained from the COE in 1989 for remedial excavation of the facility dike and adjacent areas along the Gunnison River. This permit is valid through November 1993.

- Six State of Colorado air emission permits for air emission sources on the facility and for GJPORAP activities. The permits are valid through 1993 and were issued as follows:

- Permit No. 90ME402-1: Issued for the Analytical Chemistry Laboratory; acid consumption is limited to 900 gallons per year (gal/yr), volatile organic compound consumption is limited to 2,000 gal/yr. All permit conditions were met in 1992.

- Permit No. 90ME402-2: Issued for the Sample Preparation Facility; processing of soil samples is limited to 66 tons per year (tons/yr). All permit conditions were met in 1992.

- Permit No. 90ME402-3: Issued for the facility heating boiler; consumption of natural gas is limited to $30 \times 10^{6}$ cubic feet per year; consumption of \#2 fuel oil is limited to $281 \times 10^{3} \mathrm{gal} / \mathrm{yr}$. All permit conditions were met in 1992.

- Permit No. 90ME402-4: Issued for the Petrology Laboratory, blueprint machine, degreasing unit in Building 28, and paint booth; consumption of solvent for degreaser is limited to $55 \mathrm{gal} / \mathrm{yr}$, aqueous ammonium hydroxide for the blueprint machine is limited to $12 \mathrm{gal} / \mathrm{yr}$, and paints and thinners are limited to $200 \mathrm{gal} / \mathrm{yr}$. All permit conditions were met in 1992.

- Permit No. 89ME080-1F: Issued for removal of GJPORAP material; removal of material is limited to 307,495 tons/yr. All permit conditions were met in 1992.

- Permit No. 89ME080-2F: Issued for placement of GJPORAP material at state-owned repository; placement of material is limited to 307,495 tons/yr. All permit conditions were met in 1992. 


\section{Environmental Program Information}

\section{Sources of Contamination}

A historical survey (McGinley 1987, 1988) and a radiological characterization (Henwood and Ridolfi 1986) were conducted to determine the nature and extent of contaminated materials at the GJPO facility. The historical survey indicated that the pilot-plant operations of the 1940s and 1950s were almost exclusively responsible for the contaminated materials at the facility. The radiological characterization summarized the findings of surface-soil surveys, soil borings, subsurface radiological logging, North and South Pond sediment sampling, and building surveys. From these studies and from information generated during initial phases of remedial action at the site, the total volume of uranium tailings and tailings-contaminated material was estimated at 191,000 cubic meters $(250,000$ cubic yards). The tailings and related materials occupied approximately 8 hectares ( 20 acres). Areas of contamination included the Tailings area, the North Pond area, the Leased Army Reserve area, the South Pond area, the dike area along the Gunnison River, and a number of smaller, scattered locations (see Figure 2). A critical pathway analysis, which identified sources of radiation and pathways of radiation exposure at the facility, was performed in 1987 and documented in the GJPO facility RI/FS-EA (UNC Geotech 1989).

\section{Environmental Monitoring Summary}

Air

\section{Atmospheric Radon}

An atmospheric radon monitoring program was established at the GJPO facility in 1984 and continues today. At the conclusion of the 1984 sampling period, the number of sampling locations was reduced from 25 to 8 but was increased to 13 in November 1990 in response to GJPORAP activities. Atmospheric radon concentration is measured with Landauer Radtrak ${ }^{\circledR}$ alpha-sensitive detectors. The detectors, placed in duplicate 1 meter above the ground surface (see Figure 3 for locations), are collected and analyzed on a quarterly (3-month exposure) basis.

Results of the 1992 radon monitoring program are summarized in Table 1 and listed by sampling period in Tables A-1 through A-4 in Appendix A. Table 1 also compares measured averages of 1992 data with the derived concentration guide (DCG) established for radon by DOE Order 5400.5, Radiation Protection of the Public and the Environment. Used as reference values for conducting radiological environmental protection programs, DCGs represent concentrations that would cause a member of the public, residing at the point of collection, to receive a dose of $100 \mathrm{mrem}$ in a year from inhalation of radon gas or a specific radionuclide. The radon DCG established for DOE facilities is $3.0 \times 10^{-9}$ microcuries per milliliter $(\mu \mathrm{Ci} / \mathrm{mL})$ above natural background; background levels at the GJPO are $0.84 \times 10^{-9} \mu \mathrm{Ci} / \mathrm{mL}$ (UNC Geotech 1989). As indicated in 


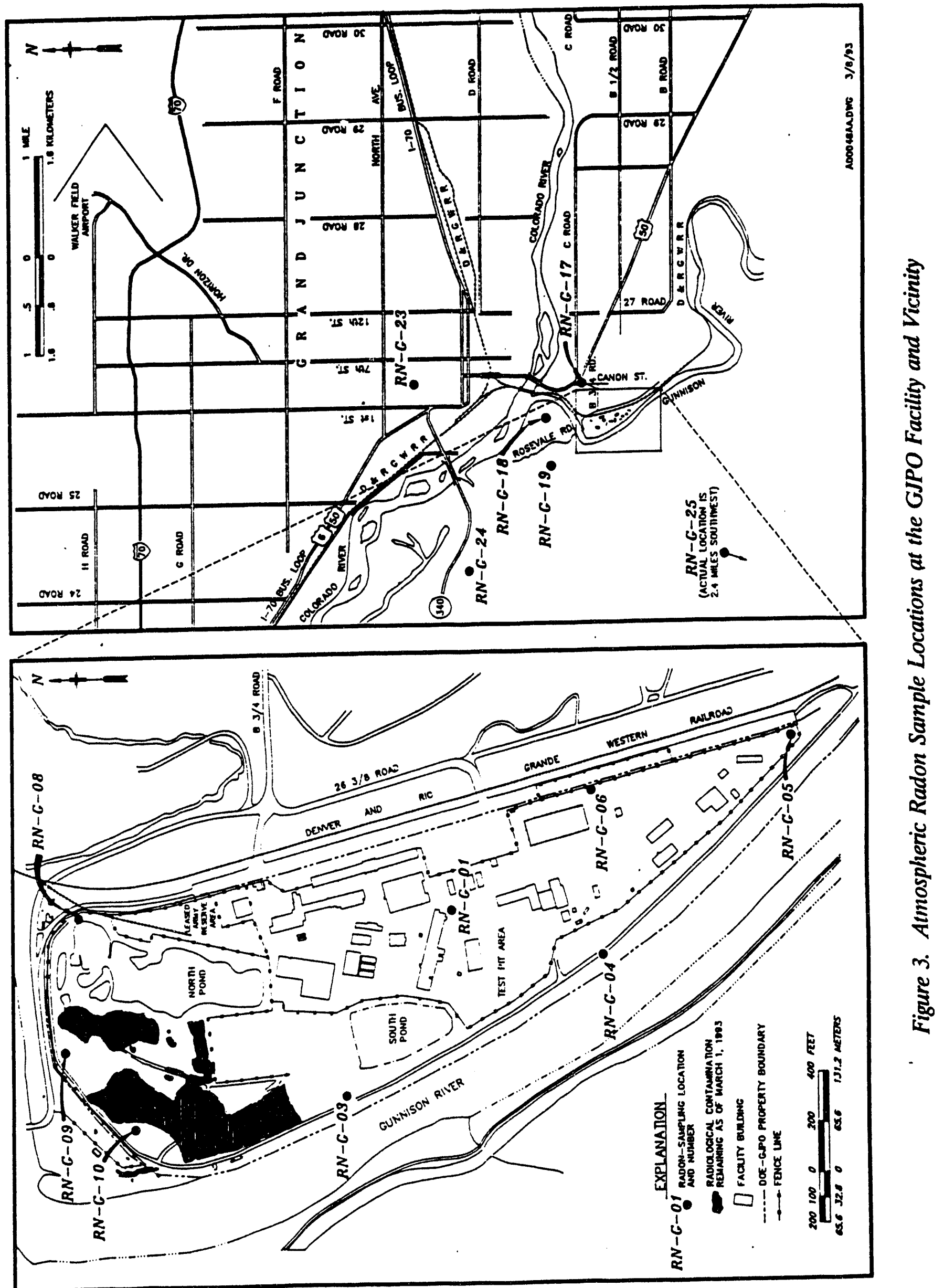


Table 1. Comparison of Average Annual Radon Concentrations At and Near the GJPO Facility with the DCG

\begin{tabular}{|c|c|c|}
\hline \multirow[b]{2}{*}{$\begin{array}{l}\text { Sampling } \\
\text { Location }\end{array}$} & \multicolumn{2}{|c|}{ Radon Concentration ${ }^{\mathrm{a}}$} \\
\hline & $\begin{array}{l}\text { Annual } \\
\text { Average } \\
(\mathrm{ci} / \mathrm{mL})^{b}\end{array}$ & $\begin{array}{c}\text { DCG } \\
\text { (Including background) } \\
(\mu \mathrm{Ci} / \mathrm{mL})\end{array}$ \\
\hline On-Site & . & \\
\hline $\begin{array}{l}R N-G-01 \\
R N-G-03 \\
R N-G-04 \\
R N-G-05 \\
R N-G-08 \\
R N-G-09 \\
R N-G-10\end{array}$ & $\begin{array}{l}6.50 \mathrm{E}-10 \\
6.38 \mathrm{E}-10 \\
5.75 \mathrm{E}-10 \\
5.13 \mathrm{E}-10 \\
4.83 \mathrm{E}-10 \\
9.13 \mathrm{E}-10 \\
4.00 \mathrm{E}-10\end{array}$ & $\begin{array}{l}3.84 E-09 \\
3.84 E-09 \\
3.84 E-09 \\
3.84 E-09 \\
3.84 E-09 \\
3.84 E-09 \\
3.84 E-09\end{array}$ \\
\hline \multicolumn{3}{|l|}{ Off-Site } \\
\hline $\begin{array}{l}R N-G-17 \\
R N-G-18 \\
R N-G-19 \\
R N-G-23 \\
R N-G-24 \\
R N-G-25\end{array}$ & $\begin{array}{l}5.13 \mathrm{E}-10 \\
6.63 \mathrm{E}-10 \\
5.13 \mathrm{E}-10 \\
4.25 \mathrm{E}-10 \\
6.38 \mathrm{E}-10 \\
5.38 \mathrm{E}-10\end{array}$ & $\begin{array}{l}3.84 E-09 \\
3.84 E-09 \\
3.84 E-09 \\
3.84 \bar{c}-09 \\
3.84 E-09 \\
3.84 E-09\end{array}$ \\
\hline
\end{tabular}

ascientific notation $E=" \times 10 "$.

$b_{1} \mu C \mathrm{i} / \mathrm{mL}=3.7 \times 10^{4}$ becquerel $\mathrm{s} / \mathrm{mL}$.

Table 1, average annual radon concentrations at all locations were below the DCG, which is consistent with previous years' results. On-site radon concentrations in 1992, however, generally were lower than those measured in 1991 . This overall decrease in concentration probably occurred as a result of GJPORAP activities, which included removal of on-site radon sources (mill tailings and tailings-contaminated soil).

\section{Air Particulates}

Air particulate monitoring is conducted to comply with all applicable local, state, and federal regulatory requirements. DOE Order 5400.1, General Environmental Protection Program, specifies that effluent monitoring will be conducted to provide representative measurements of the quantities and concentrations of pollutants in airborne discharges. Demonstrations of compliance with the public dose limits of DOE Order 5400.5 and 40 CFR 61, Subpart H, National Emission Standards for Emissions of Radionuclides Other Than Radon From Department of Energy Facilities, are based on calculations that use information obtained from environmental monitoring programs. In addition, DOE 
Order 5400.5 lists DCGs for air that provide reference values for conducting radiological environmental protection programs. The DOE guidance document, Radiological Effluent Monitoring and Environmental Surveillance (DOE 1991b), recommends identifying and monitoring diffuse sources such as tailings piles. National primary and secondary ambient air quality standards (40 CFR 50), which have been deemed appropriate and applicable for this facility, define maximum acceptable levels of particulate matter.

The GJPO ambient air particulate sampling program was initiated in December 1985 to monitor GJPORAP activities and to monitor the impact of radionuclide point source emissions on the facility's air quality. The initial air particulate sampling network consisted of three high-volume air. samplers that sampled ambient air at 40 standard cubic feet per minute $(\mathrm{scfm})$ for 24 hours every sixth day. Metal towers were erected on concrete pads at the sampling sites, and samplers were mounted with filters 3 meters (10 feet) above ground level. In 1987, 10-micrometer $(\mu \mathrm{m})$ size-selective inlets were installed in the intake of the sampler to separate particulate matter $10 \mu \mathrm{m}$ or smaller $\left(\mathrm{PM}_{10}\right)$ from larger particles. The $10-\mu \mathrm{m}$ or smaller particles are considered to be the biologically damaging component and are collected on the glass-fiber filter in the sampler. The heavier windblown particulates and fugitive dust are eliminated by the $10-\mu \mathrm{m}$ size-selective inlet.

The sampling sites (see Figure 4) were selected on the basis of prevailing wind directions at the GJPO facility. Two principal wind vectors occur: north-northwest and southsoutheast. The south station (AIR-G-1) is located in the south portion of the facility near Building 35; the west station (AIR-G-2) is located on the north edge of the Tailings Area; and the north station (AIR-G-3) is located in the north portion of the facility, northeast of the North Pond.

The 1992 air particulate sampling network consisted of three high-volume air particulate samplers. Radiological analytes, which included uranium (natural), radium-226, and thorium-230, were sampled continuously for a 5-day period each month. $\mathbf{P M}_{10}$, the only nonradiological constituent measured, was sampled for a 24-hour period every sixth day. A summary of 1992 results are in Table 2, and results of individual sample analyses are in Tables A-5 through A-10 in Appendix A.

Table 2 compares uranium, radium-226, and thorium-230 DCGs (inclusive of background levels) with maximum and average concentrations measured at the GJPO facility during 1992. All measured concentrations are well below the respective DCGs. In Appendix B, Figures B-1 through B-3 show concentrations of uranium, thorium-230, and radium-226 as a percentage of their respective DCGs at station AIR-G-2 during 1992. Graphs for monitoring stations AIR-G-1 and AIR-G-3, although not included in this report, exhibit trends similar to AIR-G-2 graphs.

Acceptable levels of $\mathrm{PM}_{10}$ are defined by the EPA under the National Ambient Air Quality Standards; these levels have been adopted by the state of Colorado. The $\mathbf{P M}_{10}$ standard specifies a maximum annual average concentration of 50 micrograms per cubic meter $\left(\mu \mathrm{g} / \mathrm{m}^{3}\right)$ and a maximum 24-hour concentration of $150 \mu \mathrm{g} / \mathrm{m}^{3}$. Maximum measured values for this constituent in 1992 were below compliance levels (Table 2). In Appendix B, Figure B-4 shows $\mathrm{PM}_{10}$ concentrations as a percentage of the EPA/state 


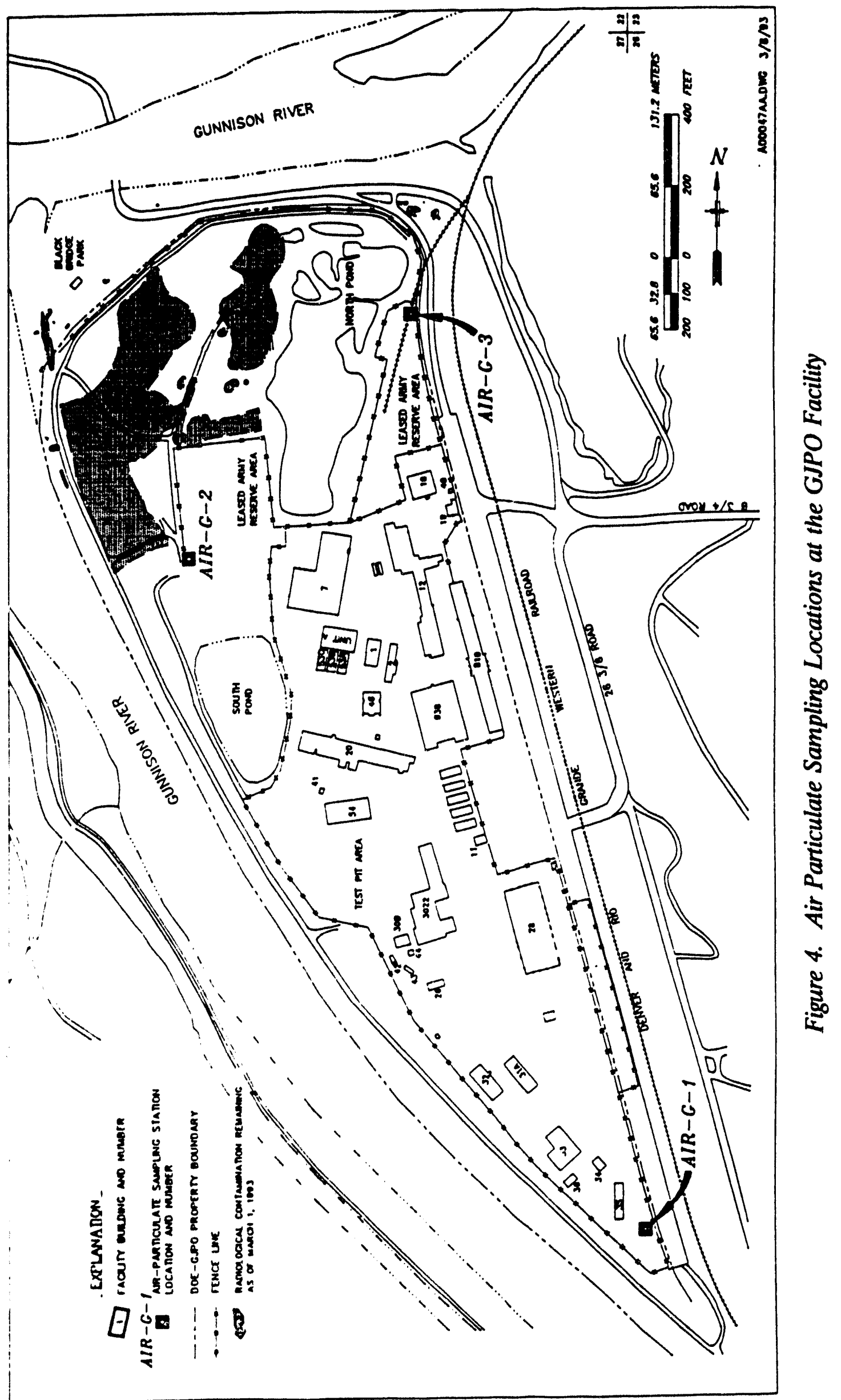


Table 2. Results of the GJPO Air Particulate Monitoring Conducted during $1992^{a, b}$

\begin{tabular}{|c|c|c|c|c|c|c|c|}
\hline & & \multicolumn{5}{|c|}{ Radiological Elements } & \multirow{2}{*}{$\begin{array}{c}\begin{array}{c}\text { Suspended } \\
\text { Particulates }\end{array} \\
\text { PN-10 } \\
\left(\mathrm{mg} / \mathrm{m}^{3}\right)\end{array}$} \\
\hline & & 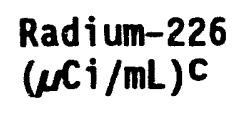 & 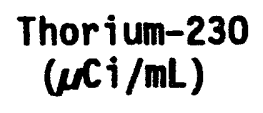 & $\begin{array}{l}\text { Thor ium-230 } \\
\text { (pg/mL) }\end{array}$ & $\begin{array}{l}\text { Uranium } \\
\text { (pg/mL) }\end{array}$ & 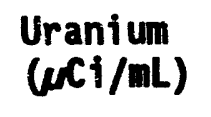 & \\
\hline \multicolumn{2}{|c|}{ DCG/Standard } & $1.0 \mathrm{E}-12$ & $4.0 E-14$ & No Standard & No Standard & $2.0 E-12$ & $\begin{array}{l}150 \text { Maximum } \\
50 \text { Annual Ave. }\end{array}$ \\
\hline $\begin{array}{l}\text { Station } \\
\text { AIR-G-1 }\end{array}$ & $\begin{array}{l}\text { Maximum } \\
\text { Average } \\
\text { Count }\end{array}$ & $\begin{array}{l}7.8 E-16 \\
2.9 E-16 \\
12(4)\end{array}$ & $\begin{array}{l}2.1 \mathrm{E}-16 \\
1.4 \mathrm{E}-16 \\
12(7)\end{array}$ & $\begin{array}{l}1.1 E-08 \\
7.2 E-09 \\
12(7)\end{array}$ & $\begin{array}{l}4.4 E-04 \\
2.4 E-04 \\
12(12)\end{array}$ & $\begin{array}{l}2.9 \mathrm{E}-16 \\
1.6 \mathrm{E}-16 \\
12(12)\end{array}$ & $\begin{array}{l}45.1 \\
18.0 \\
57(57)\end{array}$ \\
\hline AIR-G-2 & $\begin{array}{l}\text { Maximum } \\
\text { Average } \\
\text { Count }\end{array}$ & $\begin{array}{l}2.1 E-15 \\
7.7 E-16 \\
11(6)\end{array}$ & $\begin{array}{l}1.9 \mathrm{E}-15 \\
4.5 \mathrm{E}-16 \\
11 \text { (11) }\end{array}$ & $\begin{array}{l}9.8 \mathrm{E}-08 \\
2.3 \mathrm{E}-08 \\
11(11)\end{array}$ & $\begin{array}{l}1.2 \mathrm{E}-03 \\
4.6 \mathrm{E}-04 \\
11(11)\end{array}$ & $\begin{array}{l}8.0 \mathrm{E}-16 \\
3.1 \mathrm{E}-16 \\
11(11)\end{array}$ & $\begin{array}{l}48.8 \\
18.0 \\
47(47)\end{array}$ \\
\hline AIR-G-3 & $\begin{array}{l}\text { Maximum } \\
\text { Average } \\
\text { Count }\end{array}$ & $\begin{array}{l}6.4 E-16 \\
4.1 E-16 \\
12(3)\end{array}$ & $\begin{array}{l}4.4 E-16 \\
1.4 E-16 \\
12(10)\end{array}$ & $\begin{array}{l}2.3 E-08 \\
7.2 E-09 \\
12(10)\end{array}$ & $\begin{array}{l}3.9 \mathrm{E}-04 \\
2.6 \mathrm{E}-04 \\
12(12)\end{array}$ & $\begin{array}{l}2.6 \mathrm{E}-16 \\
1.7 \mathrm{E}-16 \\
12(12)\end{array}$ & $\begin{array}{l}52.8 \\
19.6 \\
51(51)\end{array}$ \\
\hline
\end{tabular}

aThe numbers given in this table are defined as follows:

Maximum - Maximum concentration.

Average - Average annual concentration. Only concentrations above the detection limit were used in this calculation.

Count - Number of samples collected (number of samples having concentrations above detection limits).

bScientific notation $E=" x 10 . "$

C1 $\mu \mathrm{Ci} / \mathrm{mL}=3.7 \times 10^{4}$ becquerels $/ \mathrm{mL}$. 
standard for station AIR-G-2 during 1992. Although not included, graphs for the other two monitoring stations exhibit trends similar to AIR-G-2.

\section{Radionuclide Point Source Emissions}

Three point sources of radionuclide emissions occur on the GJPO facility: the Analytical Chemistry Laboratory, the Oak Ridge National Laboratory (ORNL) Sample Preparation Trailer, and the Sample Preparation facility (Baghouse). Because of the low emission rates from these sources, the EPA, Region VIII, Office in 1991 waived the sampling requirements indefinitely for the Analytical Chemistry Laboratory and the ORNL Trailer and granted a 1-year waiver for the Baghouse. However, emissions from these sources must be estimated using the method contained in 40 CFR 61, Appendix D. Estimated emissions were calculated and entered into the dose model AIRDOSPC ${ }^{\mathrm{m}}$. Because of the extremely small quantities emitted from the Analytical Chemistry Laboratory and the ORNL Trailer, and because of the proximity of all three sources, the Analytical Chemistry Laboratory and ORNL Trailer source terms were combined with the Baghouse source term and treated as a single release point. Results of the modeling estimated an effective dose equivalent (EDE) to the maximally exposed individual (400 meters west-northwest of the facility) of $1.100 \times 10^{-3} \mathrm{mrem} / \mathrm{yr}$, well below the DOE and EPA limit of $10 \mathrm{mrem} / \mathrm{yr}$.

\section{Direct Gamma Radiation Monitoring}

A direct environmental radiation monitoring program was begun at the GJPO facility in April 1991 to assess the potential gamma radiation dose to persons on and near the facility, in accordance with DOE Order 5400.5 and the DOE Environmental Regulatory Guide for Radiological Effluent Monitoring and Environmental Surveillance (DOE 1991b). Gamma radiation measurements are included, along with radiation measurements associated with radon and air particulates, in the calculation of total off-site dose to the public to determine compliance with the DOE standard of $100 \mathrm{mrem} / \mathrm{yr}$ above background (see Environmental Radiological Program Information section).

During 1992, radiation measurements were made with $\mathrm{CaSO}_{4}: \mathrm{Dy}$ (calcium sulfate: dysprosium) thermoluminescent dosimeters (TLDs). Fifteen monitoring locations (Figure 5) on the GJPO facility and surrounding areas were monitored quarterly.

Results of the monitoring are presented in Tables A-11 through A-14 in Appendix A and are summarized in Table 3, which compares measured values with the DOE standard. The background level of gamma radiation, measured at TLD-G-15, was estimated at $91 \mathrm{mrem} / \mathrm{yr}$. All on-site and off-site locations yielded annual average measurements well below the DOE standard. 


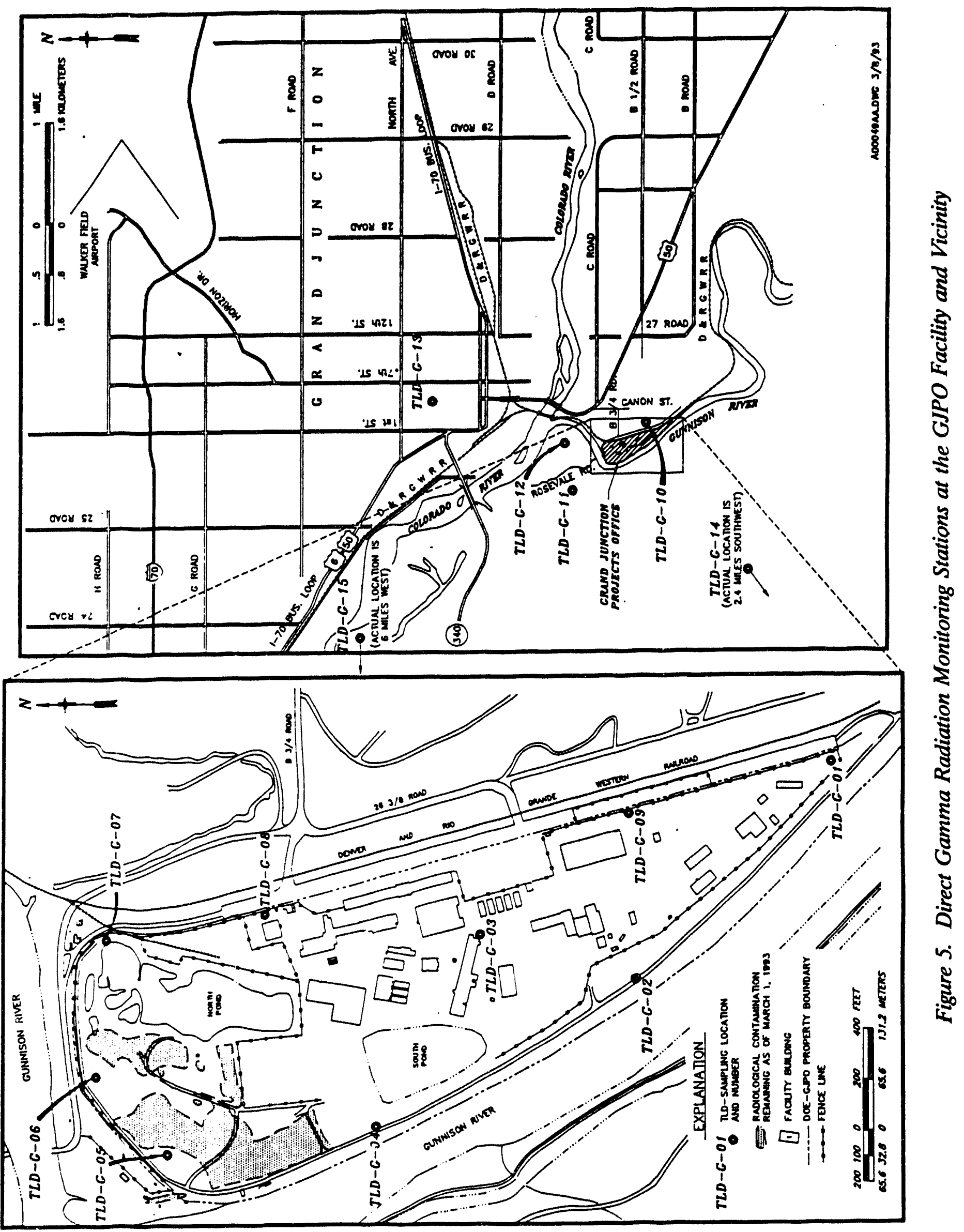


Table 3. Average Annual Gamma Exposure Rates At and Near the GJPO Facility during 1992

\begin{tabular}{lrc}
\hline & & Gamma Exposure \\
\cline { 2 - 3 } Sampling & $\begin{array}{c}\text { Annual Average } \\
\text { Location }\end{array}$ & $\begin{array}{c}\text { DoE Standard } \\
\text { (mrem/yr) }\end{array}$ \\
\hline On-Site & & \\
TLD-G-01 & & \\
TLD-G-02 & 94 & 191 \\
TLD-G-03 & 96 & 191 \\
TLD-G-04 & 112 & 191 \\
TLD-G-05 & 110 & 191 \\
TLD-G-06 & 98 & 191 \\
TLD-G-07 & 102 & 191 \\
TLD-G-08 & 97 & 191 \\
TLD-G-09 & 103 & 191 \\
Off-Site & 103 & 191 \\
TLD-G-10 & & \\
TLD-G-11 & & 191 \\
TLD-G-12 & 86 & 191 \\
TLD-G-13 & 89 & 191 \\
TLD-G-14 & 94 & 191 \\
TLD-G-15 & 89 & 191 \\
& 91 & 191 \\
\hline
\end{tabular}

al $\mathrm{mrem} / \mathrm{yr}=.01 \mathrm{millisieverts} / \mathrm{yr}$.

bstandard includes background of $91 \mathrm{mrem} / \mathrm{yr}$.

\section{Meteorology}

Meteorological monitoring was not conducted at the GJPO during 1992. Because of problems associated with installation of a new system, valid data were not collected and are therefore not included in this report. Meteorological data representative of the GJPO were obtained from the National Weather Service Office in Grand Junction, Colorado, and used in the dose modeling. A copy of this data is in Table A-15, Appendix A.

\section{Water}

\section{Sewer Effluent}

In March 1989, an industrial pretreatment permit (No. 0023) was issued to the GJPO by the city of Grand Junction and Mesa County. This permit was issued in accordance with 
provisions in Article 10 of Chapter 25, Code of Ordinance for the city of Grand Junction. Article 10 sets forth uniform requirements for users of city and county publicly owned wastewater treatment works and enables the city to comply with applicable state and federal laws. These laws include the Clean Water Act of 1977, the General Pretreatment Regulations (40 CFR 403), and the Colorado Water Quality Control Act, all as amended. In addition, Article 10 requires monitoring, enforcement activities, and user reporting.

Under provisions of the industrial pretreatment permit, the GJPO is required to sample its sewer effluent semiannually and report the results to the city by January 31 and July. 31 each year. Table 4 lists the constituents required to be sampled and their respective threshold limits, as established by the permit.

During 1992, sewer effluent was sampled monthly, with the exception of September, October, and November, for the required constituents at the location labeled as Manhole \#12 in Figure 6. Except for the December BOD and TSS concentrations, all constituent concentrations measured during the year were below or within their respective threshold limits. Table 4 summarizes the results of the sampling and provides a comparison of the results with threshold limits and with historical maximum concentrations. A complete list of sewer effluent sampling results is in Appendix A, Tables A-16 and A-17.

During the December 1992 sampling episode, the analytical results for BOD and TSS exceeded the permitted discharge limits. A resampling of the effluent was begun immediately. During resampling, it was discovered that the electrical cables that connected the flow sensor to the dedicated sampling line had become dislodged and had caused an accumulation of solid debris within the sewer line. The cables were moved, the sample site was flushed, and the cables were repositioned to avoid future accumulation of debris. Results obtained from the analysis of the sample collected after the sample site was cleaned were well below the permitted discharge limits for BOD and TSS.

In addition to the required constituents, sewer effluent was sampled monthly (with the exception of September, October, and November) for gross alpha, gross beta, total dissolved solids, chemical oxygen demand, total organic halides, and total organic carbon. The purposes of this sampling were (1) to establish baseline concentrations of these constituents within the effluent and (2) to demonstrate compliance with DOE Order 5400.5, which establishes limits on the discharge of radionuclides into the sewer system. Gross alpha and gross beta analytical results indicated that monthly radionuclide concentrations were well below established DCG values (listed in Chapter III of DOE Order 5400.5). Results of these analyses are in Appendix A, Table A-16.

On February 24, 1992, a comprehensive characterization of sewer effluent was conducted to provide information to the city of Grand Junction/Mesa County for an update of the industrial pretreatment permit. The characterization included an analysis of organic compounds, semivolatile organic compounds, herbicides, pesticides, and inorganic metals. Data from this sampling are in Appendix A, Tables A-16 and A-17. 
Table 4. Comparison of 1992 and Historical Sewer Effluent Maximum Concentrations with Permitted Threshold Limits ${ }^{a, b}$

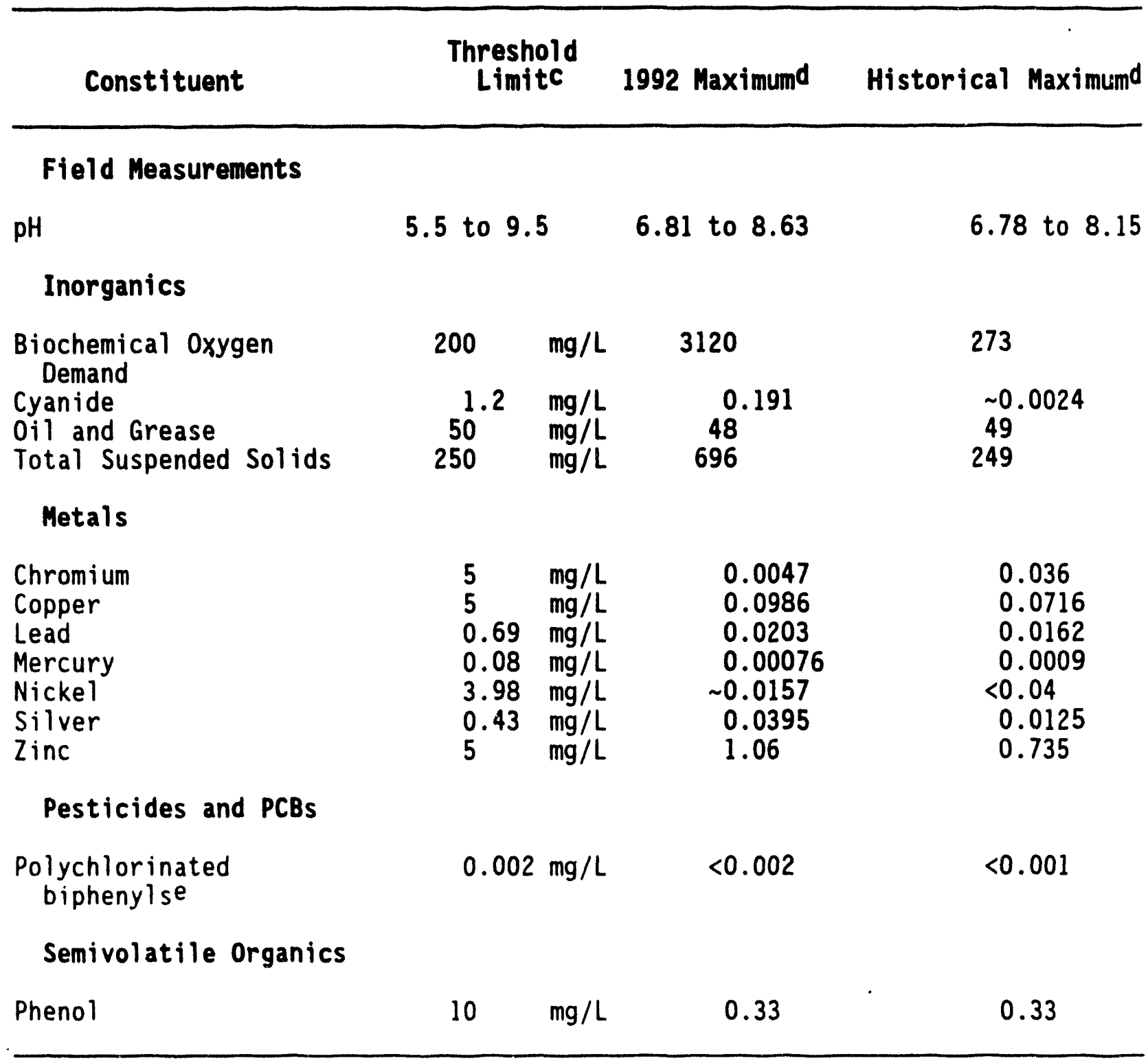

$a_{A}$ " $<"$ indicates that the maximum concentration was below detection limits (number shown is detection limit); a " $"$ indicates an approximate value (the value was outside the limits for which the instrument was calibrated). bl992 industrial pretreatment permit No. 0023 issued by the city of Grand Junction.

CMaximum allowable contaminant levels. column.

The listed values are in the units shown under the Threshold Limit epolychlorinated biphenyls include Aroclor 1016, 1221, 1232, 1242, 1248, 1254, and 1260 . 


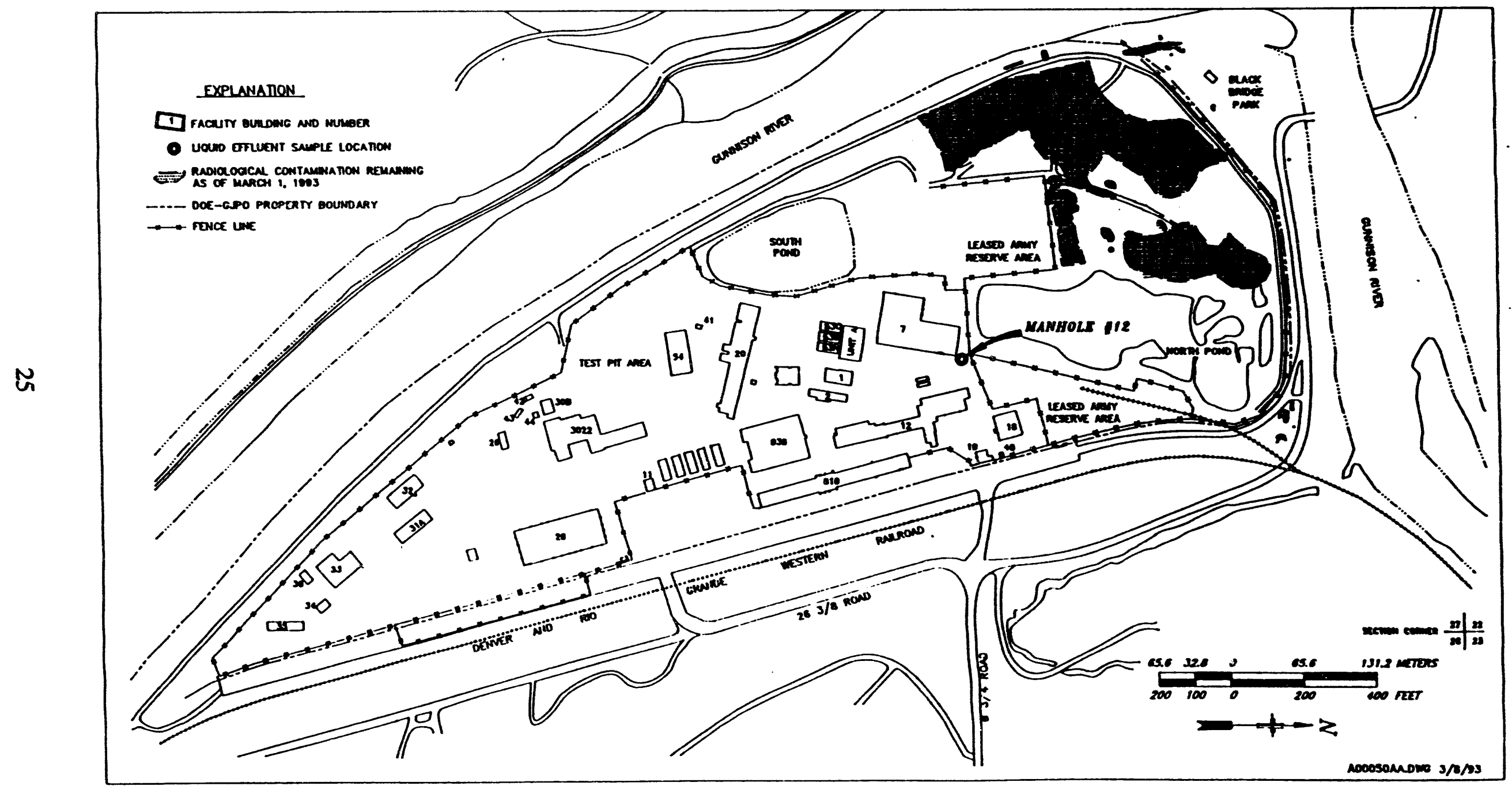

Figure 6. Sewer Effluent Sampling Location at the GJPO Facility 


\section{Surface Water}

Surface-water sources at or near the GJPO facility include the Gunnison River, North Pond, and South Pond. The Gunnison River is adjacent to the facility, flowing along its west boundary, and the North and South Ponds are located on the facility property (Figure 7). All of these sources contain water perennially.

In accordance with the Colorado Water Quality Control Act, four state use classifications have been applied to the segment of the Gunnison River adjacent to the GJPO facility: (1) Recreation Class I, (2) Cold Water Aquatic Life Class I, (3) Domestic Water Supply, and (4) Agriculture. Table 5 lists the most stringent numeric water quality standards associated with these classifications. In the vicinity of the facility, the river is used for irrigation and for limited seasonal recreational activities such as boating, fishing, and swimming.

In 1990, surface-water sampling frequency was increased from a semiannual to a quarterly basis when remedial activities commenced at the GJPO facility. Quarterly sampling continued throughout 1991 and 1992. Grab samples were taken from six locations at or near the facility: four from the Gunnison River and one each from the North and South Ponds. Gunnison River samples were taken upstream of, adjacent to (two samples), and downstream of the facility near the shore of the river; the North and South Ponds were sampled near their west shores.

Surface waters were analyzed for specific conductance, $\mathrm{pH}$, and alkalinity in the field and arsenic, barium, cadmium, calcium, chloride, chromium, iron, lead, magnesium, manganese, molybdenum, nitrate, potassium, selenium, sodium, sulfate, total organic carbon, vanadium, gross alpha, radium-226, radium-228, uranium-234, uranium-238, and thorium-230 in the laboratory. These analytes were chosen to characterize general water quality and to monitor the effects of contaminated alluvial ground water on surface-water quality. Maximum historical analyte concentrations and 1992 analyte concentrations within the Gunnison River are summarized and compared with state standards in Table 5. Several constituents listed in the table, such as copper, mercury, nickel, silver, zinc, nitrite, dissolved oxygen, and fecal coliform, were not analyzed for in 1992 because they were measured historically, and either no standards were exceeded or no relationship was found between alluvial ground-water contamination and Gunnison River concentrations for those analytes. A complete list of surface-water sampling results for 1992 is in Tables A-18 through A-21 in Appendix A.

Analyte concentrations observed in samples from the river, with the exception of sulfate and manganese, were below or within applicable state standards. Sulfate concentrations exceeded the standard at all sampling locations on the river in March, September, and December. Manganese concentrations exceeded state standards at upstream and downstream locations in March and at all locations in December. Maximum concentrations for manganese and sulfate in 1992 occurred at the on-site sampling locations. Currently, there is no evidence that discharges from the alluvial aquifer are contributing to these elevated concentrations in the Gunnison River. With the exception of uranium, no spatial or temporal patterns have been observed for any of the analyte concentrations. 


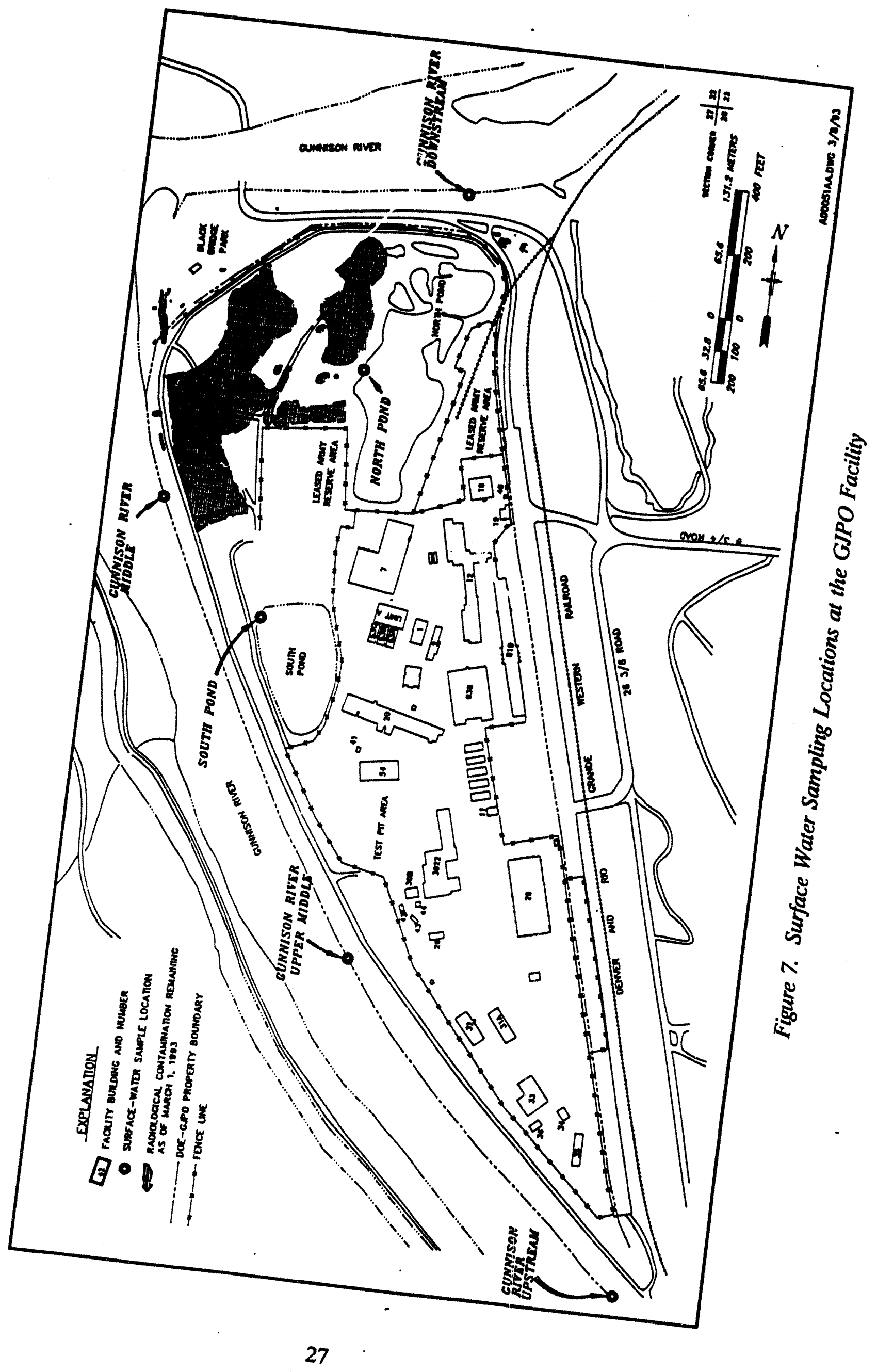



Table 5. Comparison of State of Colorado ${ }^{a}$ Surface Water Quality Standards with 1992 and Historical Maximum Concentrations in the Gunnison River

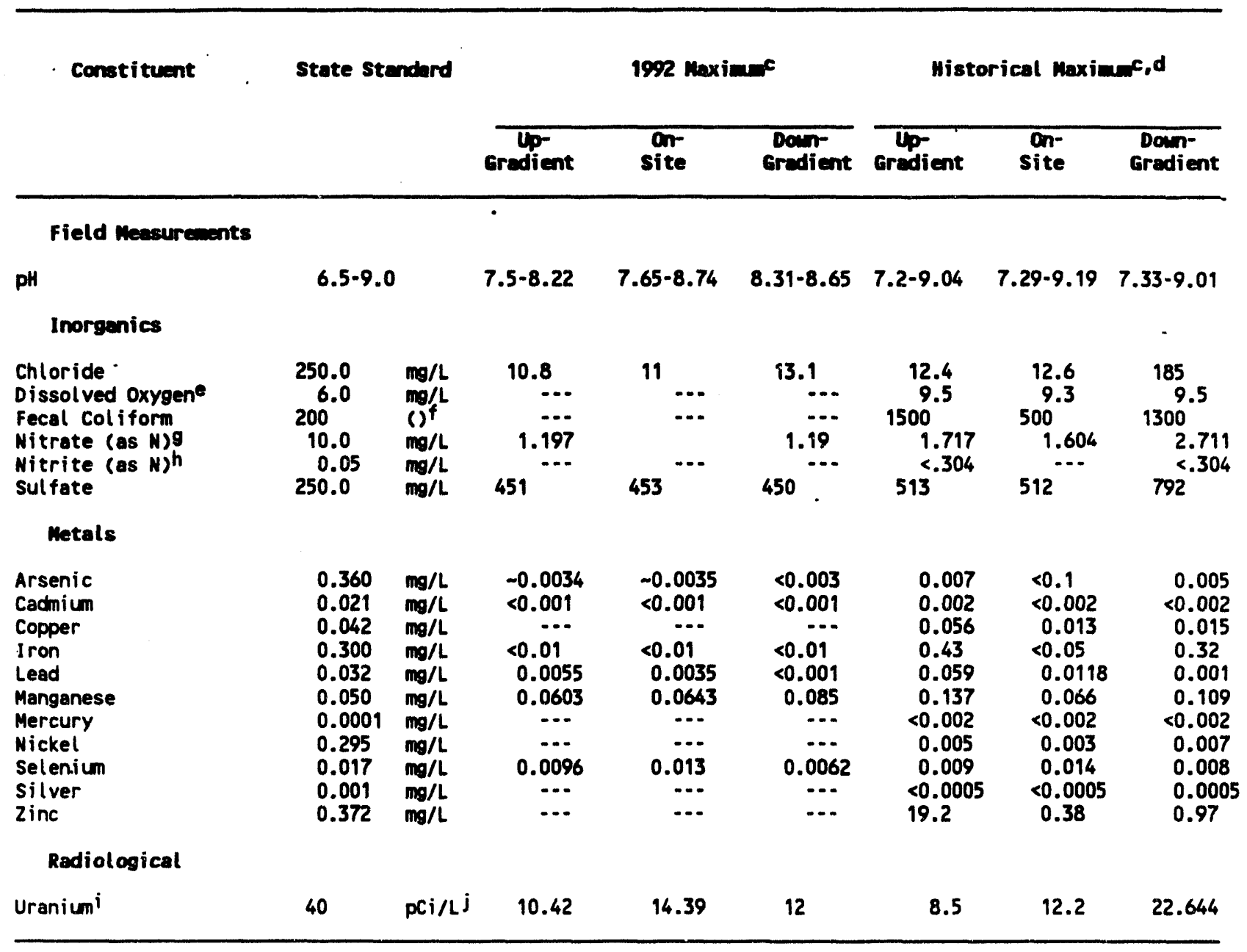

\footnotetext{
aColorado Department of Health Water Quality Control Division, Standards for the Gunnison River segment, revised January $30,1991$.

$b_{A}$ "...." indicates no data available; a "<" indicates that the maximum concentration was below detection limits (number shown is detection limit); a "u" indicates an approximate value (the value was outside the limits for which the instrument was calibrated).

cThe values are in units shown under the standards column.

dBased on maximum concentrations observed from 1980 through 1991.

eMeasured values represent the minimum measurement observed; compliance with the standard is indicated by a quant ity larger than the standard.

fColonies $/ 100 \mathrm{~mL}$

9Nitrate (as $N$ ) was derived for measured Nitrate using the conversion: Nitrate (as $N$ ) $=N_{3} \div 4.427$.

$h_{N i t r i t e}$ (as N) was derived for measured Nitrite using the conversion: Nitrite (as $N$ ) $=\mathrm{NO}_{2} \div 3.285$.

iUranium concentrations which were measured in $\mathrm{mg} / \mathrm{L}$ were converted to $\mathrm{PC} i / \mathrm{L}$ for comparison purposes. The conversion assumes equilibrium and an activity of $0.666 \mathrm{pCi} / \mathrm{L}$.

$\mathrm{j}_{1} \mathrm{pCi} / \mathrm{L}=3.7 \times 10^{-2}$ becquerels $/ \mathrm{L}$.
} 
Uranium concentrations within the Gunnison River may have been affected by alluvial ground-water discharges but not to the extent that state water quality standards were exceeded. Figures B-5 through B-7 (Appendix B) show uranium concentrations over time at the upstream, on-site, and downstream sampling locations on the Gunnison River. Generally, concentrations of uranium are higher at the downstream location than at either the upstream or on-site locations, and increases and decreases in uranium concentrations at the three sampling locations occur at the same time. These trends may indicate a discharge of uranium-contaminated ground water into the Gunnison River. Uranium concentrations will continue to $b$. monitored to detect further changes in surfacewater quality that may occur in response to on-site mill tailings remediation.

The North and South Ponds are recharged by the shallow alluvial aquifer underlying the facility and express some of the same characteristics as the ground water (see Ground-Water Protection Program section of this report): Like the ground water, these surface water sources are contaminated by the leached products of uranium mill tailings.

Although state surface water standards for the Gunnison River are not applicable to these water bodies, the standards provide a useful reference for contaminant evaluations.

Concentrations of chloride, manganese, uranium-234 and -238, and sulfate in the North Pond exceeded state standards for these constituents during 1992. The maximum chloride concentration was 414 milligrams per liter $(\mathrm{mg} / \mathrm{L})$, the maximum manganese concentration was $0.287 \mathrm{mg} / \mathrm{L}$, the maximum uranium-234 and -238 activity was 363.5 picocuries per liter (pCi/L), and the maximum sulfate concentration was $3,200 \mathrm{mg} / \mathrm{L}$ (see Tables A-18 through A-21, Appendix A). In the South Pond, concentrations of manganese, uranium-234 and -238 , and sulfate exceeded state standards. The maximum manganese concentration was $1.8 \mathrm{mg} / \mathrm{L}$, the maximum uranium-234 and -238 concentration was $474.94 \mathrm{pCi} / \mathrm{L}$, and the maximum sulfate concentration was $1,900 \mathrm{mg} / \mathrm{L}$ (see Tables A-18 through A-21).

Remedial activities at the GJPO facility include removal of the source of ground- and surface-water contamination. When these sources have been removed, water quality should improve over time in the Gunnison River and North and South Ponds.

\section{Environmental Permits and Document Preparation}

Permits obtained in 1992 for the GJPO facility and GJPORAP operations are listed in the Compliance Summary section of this report.

Environmental documents completed in calendar year 1992 included

- Monthly remediation progress reports, submitted to the EPA in compliance with an agreement made with that agency concerning NESHAP, Subpart Q, Radon Emission Requirements.

- Annual NESHAP, Subpart H, report submitted to the EPA.

- Grand Junction Projects Office Site Environmental Report for Calendar Year 1991 (ChemNuclear Geotech, Inc. 1992f). 
- Grand Junction Projects Office Facility, Grand Junction Projects Office Remedial Action Project, Monticello Mill Tailings Site Sampling and Analysis Plan for Environmental Monitoring (Chem-Nuclear Geotech, Inc. 1992g).

- 1991 Radioactive Effluent and On-Site Discharge report for the GJPO.

\section{Environmental Activities}

\section{Site Management Inspections}

Inspections of the GJPO facility were conducted on a monthly basis during 1992 . Site Management personnel were assisted by DOE and by Geotech representatives from Environmental Services, Quality Assurance, and Health, Safety, and Security. The inspections focused on waste management, pollution prevention, safety, and general housekeeping. The inspection team examined work areas, equipment storage areas, aboveground storage tanks, waste storage areas, and ongoing work. An important aspect of the inspections was the identification of potential environmental compliance issues related to the temporary storage of GJPO hazardous, radioactive, and mixed wastes.

\section{Self-Assessments}

The Self-Assessments Program was formally established in March 1991 at the GJPO facility to provide a comprehensive review process of activities associated with environmental protection, safety and health, management systems, and organizational structure. The objectives of the program are to achieve the highest level of safety for the public, environment, and employees at the facility and to provide feedback to management for the improvement of compliance and operations at the facility.

During 1992, 33 self-assessments were conducted for a variety of programs/procedures occurring on the GJPO facility. Topics of the self-assessments included management and organization. health and safety, and environmental concerns. To date, no conditions imminently hazardous to the environment or to health and safety have been found, although numerous corrective actions have been implemented, as a result of the self-assessments.

\section{Environmental Training}

A number of environmental training courses were conducted at the GJPO facility during 1992 in compliance with federal regulations and DOE orders. Following is a brief description of the courses:

- Environmental Awareness Training - developed by on-site personnel and offered quarterly to increase awareness of environmental regulations and requirements.

- Hazardous Waste Operations Refresher - provides an 8-hour SARA refresher course for all employees who may enter hazardous waste sites. 
- General Employee Radiation Training - completed by employees who desire unescorted access to controlled areas on the facility.

- Radiation Worker Training - completed by all employees who work in radiologically controlled areas.

- Respirator Wearer Training/Respirator Supervisor Training - completed by all employees and supervisors of employees who work in areas containing potential respiratory hazards.

- Orientation for Health, Safety, and Security - developed for new employees; identifies potential hazards on the facility, discusses requirements of 29 CFR 1910, and familiarizes employees with facility security procedures.

- Health and Safety Update - provides an annual refresher of the Orientation for Health, Safety, and Security course.

- Hazardous Materials Transportation Training - this 8-hour course familiarizes employees involved with the shipment of hazardous wastes with the requirements of the U.S. Department of Transportation regulations and DOE Order 5480.3.

- Shipment of Radioactive and Other Hazardous Materials Training - this 36-hour class provides in-depth training in U.S. Department of Transportation regulations covered in 49 CFR 171-177; it emphasizes radioactive material packaging and transportation requirements.

- Emergency Response Cadre Training - provides training for personnel assigned to be first responders to emergencies (e.g., spills) on the facility.

- Asbestos Abatement Worker/Supervisor/Management Planner Training - familiarizes employees with the proper procedures for the remediation of facilities containing asbestos.

\section{GJPORAP}

A total of 161,589 tons of contaminated material was excavated from the GJPO facility in 1992 and transported to the state-owned temporary repository in Grand Junction. Phases II, III, IC, ID, V, and IV of the remedial action were completed, and Phase IVA was begun (see CERCLA subsection of the Compliance Summary section for details).

\section{Commingled Waste Investigation Project}

The Commingled Waste Investigation : oject (CWIP) was developed to ensure that no radiologically contaminated materials commingled with hazardous wastes were transported to the state-owned temporary repository. Several commingled waste investigations were conducted in 1992 in conjunction with operational and remedial activities. In all cases, 
analytical results indicated that hazardous wastes were not present and, therefore, that the material in question was not a commingled waste. However, stored wastes from three sites excavated in 1989 and 1990 remain on site, awaiting proper disposal.

One of the sites contained waste that was excavated from a sump located on the west side of Building 31 during 1989 GJPORAP activities. Analyses of the waste showed it to be a mixed waste, and it was stored in the DOE-GJPO's hazardous and mixed waste storage unit (Building 42). Although treatment options for this waste are being pursued, none have yet to be developed and approved.

Another site, a trench located in the hallway of Building 20, was excavated in 1990. Seven 55-gallon drums of liquid and sludge were collected during cleanup of the trench. Five of the drums contained trash produced during related asbestos abatement activities in the building, whereas two of the drums contained commingled wastes: one containing mercury as a component and the other containing acetone and methylene chloride as components. Like the mixed waste excavated from the sump, these wastes are awaiting the development of treatment options before they can be disposed.

A third rommingled waste stored on the facility and awaiting disposal is the PCBcontaminated uranium mill tailings. This waste is discussed in the Compliance Summary section of this report. 


\section{Environmental Radiological Program Information}

\section{Radioactive Effluent Data}

Radioactive effluent is released from the GJPO facility in four forms: liquid sewage discharged to the city of Grand Junction publicly owned treatment works, air particulate emissions, direct gamma radiation, and atmospheric radon. Effluent type and emitting sources are

- Liquid sewage - Analytical Chemistry Laboratory

- Point sources of air particulate emissions - Baghouse; ORNL Sample Preparation Trailer; Analytical Chemistry Laboratory

- Fugitive air particulate emissions - GJPORAP activities

- Direct gamma radiation - tailings pile

- Atmospheric radon - tailings pile, test pits, and radon calibration chambers

Radioactive liquid effluent is discharged from the Analytical Chemistry Laboratory to the city sewer system. Estimated total gross alpha and gross beta discharged during 1992 was $2.008 \times 10^{-5}$ curies. Because of the numerous isotopes and elements discharged, and because of their small quantities, individual isotopes and elements were not measured in the effluent. Analysis for individual isotopes would have been conducted if the total gross alpha/gross beta concentration in any sample had been greater than five times the DCG reference value of the most stringent isotope released (plutonium-240; DCG reference value of $3 \times 10^{-8} \mu \mathrm{Ci} / \mathrm{mL}$ ). This DCG reference value was not exceeded in any sample collected during 1992.

Radionuclide emissions from the three point sources were estimated according to 40 CFR 61, Appendix D. The source terms were combined and input into the dose model AIRDOSPC $\mathrm{C}^{\mathrm{m}}$. The resulting dose estimate was $1.100 \times 10^{-3} \mathrm{mrem} / \mathrm{yr}$ EDE to the maximally exposed off-site individual (400 meters west-northwest of the GJPO facility).

Fugitive airborne emissions from the remedial action currently being performed at the GJPO also were estimated and modeled. Results of the modeling indicated an EDE of $5.600 \times 10^{-2} \mathrm{mrem} / \mathrm{yr}$, which, when combined with the dose resulting from point source emissions $\left(1.100 \times 10^{-3} \mathrm{mrem} / \mathrm{yr}\right)$, resulted in a total airborne radioparticulate dose of 5.710 $\times 10^{-2} \mathrm{mrem} / \mathrm{yr}$ (Table 6). Upon completion of the GJPO remediation, this air emission source will be eliminated. 
Table 6. Effective Dose Equivalents Caused by Radiological Emissions from the GJPO Facility

\begin{tabular}{|c|c|c|}
\hline & Standard & EDE \\
\hline $\begin{array}{l}\text { EDE from Airborne } \\
\text { Radioparticulates }\end{array}$ & $10 \mathrm{mrem} / \mathrm{yr}$ & $5.710 \times 10^{-2} \mathrm{mrem} / \mathrm{yr}^{\mathrm{b}}$ \\
\hline $\begin{array}{l}\text { Collective Effective Dose } \\
\text { (including Radon) }\end{array}$ & No Standard & $9.508 \times 10^{-3}$ person-rem $/ y^{c}$ \\
\hline Total EDE to the Publicd & $\begin{array}{l}00 \mathrm{mrem} / \mathrm{yr} \\
\text { above background }\end{array}$ & $9 \mathrm{mrem} / \mathrm{yr}$ \\
\hline
\end{tabular}

aEPA standard (40 CFR 61.92), airborne emissions only (excludes radon). o1 $\mathrm{mrem} / \mathrm{yr}=0.01 \mathrm{millisievert} / \mathrm{yr}$.

c1 person-rem/yr $=0.01$ person-sievert $/ y r$.

dSources of radiation included radon, air partjculates, and gamma.

EDOE standard from DOE Order 5400.5; background dose rate for the Grand Junction area is $117 \mathrm{mrem} / \mathrm{yr}$.

Gamma radiation was measured at 15 locations on and adjacent to the GJPO facility. All on-site and off-site locations yielded annual average measurements well below the DOE standard of $100 \mathrm{mrem} / \mathrm{yr}$ above background.

Concentrations of atmospheric radon were measured at 13 sampling locations on or near the GJPO facility during 1992. Annual average radon levels at all sampling locations were below the DCG established for DOE facilities. In addition, a radon source term derived from an earlier flux survey was input into the MICROAIRDOS ${ }^{\mathrm{rm}}$ model to determine the dose caused by radon emissions. The dose calculated by the model was $3.68 \times 10^{-2} \mathrm{mrem} / \mathrm{yr}$.

Total curies of each airborne radionuclide released during 1992 from the GJPO facility are listed in Table 7. As stated previously, total releases by radionuclide from the Analytical Chemistry Laboratory to the city sewer were not quantified. However, the estimated total release to the city sewer for all radionuclides was $2.008 \times 10^{-5}$ curies. Because sewer releases were not considered a dose pathway, they were not included in the calculation of total EDE to the public.

Sampling programs and monitoring results for these effluent sources are discussed further in the Environmental Program Information section of this report. 
Table 7. Airborne Source Terms Used in the MICROAIRDOS ${ }^{\mathrm{TH}}$ and AIRDOSPC ${ }^{\mathrm{TM}}$ Models for the GJPO

All Point Sources Combined

\begin{tabular}{|c|c|c|c|}
\hline & $\mathrm{Ci} / \mathrm{yr}^{\mathrm{a}}$ & $g / y r$ & Half Life (yr) \\
\hline $\begin{array}{l}\text { Americium-241 } \\
\text { Hydrogen-3 } \\
\text { Lead-210 } \\
\text { Plutonium-239 } \\
\text { Polonium-210 } \\
\text { Radium-226 } \\
\text { Stront ium-90 } \\
\text { Thorium-230 } \\
\text { Thorium-232 } \\
\text { Uranium-238 } \\
\text { Uranium-235 } \\
\text { Uranium-234 } \\
\text { Uranium-Total }\end{array}$ & $\begin{array}{l}1.20 \times 10^{-12} \\
2.00 \times 10^{-10} \\
3.00 \times 10^{-7} \\
1.40 \times 10^{-12} \\
3.00 \times 10^{-7} \\
4.10 \times 10^{-7} \\
3.60 \times 10^{-11} \\
4.00 \times 10^{-7} \\
4.90 \times 10^{-8} \\
7.00 \times 10^{-7} \\
4.80 \times 10^{-9} \\
3.80 \times 10^{-11}\end{array}$ & 1.98 & $\begin{array}{l}458 \\
12.5 \\
20 \\
2.4 \times 10^{4} \\
3.2 \times 10^{-1} \\
1602 \\
28 \\
7.80 \times 10^{4} \\
1.41 \times 10^{10} \\
4.51 \times 10^{9} \\
1.70 \times 10^{8} \\
2.47 \times 10^{5}\end{array}$ \\
\hline \multicolumn{4}{|c|}{ Releases from 1992 Remedial Actions } \\
\hline $\begin{array}{l}\text { Lead-210 } \\
\text { Radium-226 } \\
\text { Thorium-230 } \\
\text { Uranium-238 } \\
\text { Uranium-235 } \\
\text { Uranium-234 } \\
\text { Uranium-Total }\end{array}$ & $\begin{array}{l}4.40 \times 10^{-14} \\
1.70 \times 10^{-5} \\
1.70 \times 10^{-5} \\
2.60 \times 10^{-6} \\
1.80 \times 10^{-8} \\
2.50 \times 10^{-12}\end{array}$ & 7.92 & \\
\hline \multicolumn{4}{|c|}{ Population Dose Source Terms } \\
\hline $\begin{array}{l}\text { Americium-241 } \\
\text { Lead-210 } \\
\text { Plutonium-239 } \\
\text { Polonium-210 } \\
\text { Radium-226 } \\
\text { Radon-222 } \\
\text { Strontium-90 } \\
\text { Thorium-230 } \\
\text { Uranium-238 } \\
\text { Uranium-235 } \\
\text { Uranium-234 } \\
\text { Uranium-Total }\end{array}$ & $\begin{aligned} & 1.20 \times 10^{-12} \times 10^{-7} \\
& 3.00 \times 10^{-12} \\
& 1.40 \times 10^{-7} \\
& 3.00 \times 10^{-7} \\
& 1.74 \times 10^{-5} \\
& 19.43 \times \\
& 3.60 \times 10^{-11} \\
& 1.74 \times 10^{-5} \\
& 7.00 \times 10^{-7} \\
& 4.80 \times 10^{-9} \\
& 3.80 \times 10^{-11}\end{aligned}$ & 9.90 & $1.0 \times 10^{-2}$ \\
\hline
\end{tabular}

al $\mathrm{Ci} / \mathrm{yr}=3.7 \times 10^{10}$ becquere $\mathrm{s} / \mathrm{yr}$. 


\section{Environmental Sampling for Radioactivity}

Environmental sampling frequency, locations, and data tables for the GJPO radioactivity effluent sources are described fully in the Environmental Program Information section. Analytical methods and procedures are described in the Quality Assurance section.

\section{Off-Site Dose Modeling}

Off-site dose modeling was conducted at the GJPO during 1992 to determine compliance with NESHAP, Subpart H, and DOE Order 5400.5. Both DOE Order 5400.5 and NESHAP, Subpart $H$, limit airborne radioparticulate emissions (excluding radon) from DOE facilities so that no member of the public will receive an EDE of greater than $10 \mathrm{mrem} / \mathrm{yr}$. DOE Order 5400.5 requires the calculation of a collective population dose. Results of the off-site dose modeling (Table 6) indicated an EDE to the maximally exposed off-site individual of $5.710 \times 10^{-2} \mathrm{mrem} / \mathrm{yr}$, well below the standard of $10 \mathrm{mrem} / \mathrm{yr}$. The collective effective dose (population dose), including the rador source term, was $9.508 \times 10^{-3}$ person-rem/yr (no standard established for this dose). Listed in Table 7 are the source terms used for these dose calculations.

Total off-site dose to the public was calculated by summing individual doses caused by radon, air-particulate, and gamma emissions. The resulting total EDE to the public was 9 $\mathrm{mrem} / \mathrm{yr}$, exclusive of background, well below the DOE dose limit of $100 \mathrm{mrem} / \mathrm{yr}$ above background. Background dose rate for the Grand Junction area is $117 \mathrm{mrem} / \mathrm{yr}$. 


\section{Environmental Nonradiological Program Information}

\section{Nonradiological Effluent Data}

Nonradiological effluent sources at the GJPO facility include the sewer system, Analytical Chemistry Laboratory, Boiler Plant, Petrology Laboratory, and uranium mill tailings piles. During 1992, sewer effluent constituent concentrations were below the threshold limits established by the city of Grand Junction's industrial pretreatment permit, with the exception of BOD and TSS concentrations. These threshold limit violations occurred during the December sampling event and are discussed in the Sewer Effluent subsection of this report.

Air emission permits from the Air Pollution Control Division, $\mathrm{CDH}$, were obtained for the Analytical Chemistry Laboratory, Boiler Plant, and Petrology Laboratory. As a condition of the permits, emissions from these sources cannot exceed 20 percent opacity. During 1992, emissions from these sources met the opacity requirement.

In addition to the opacity requirement, the permit obtained for the Analytical Chemistry Laboratory established limits on the quantity of chemicals that could be used annually. The inventory of hazardous/radioactive chemicals maintained by the laboratory showed that no limits were exceeded in 1992.

The permit obtained for the Boiler Plant established limits on its annual gas consumption to ensure that individual pollutant emission rates would not exceed the limits established by Colorado Air Polkition Control Regulations. Gas consumption by the plant was within permitted limits in 1992.

Sampling during 1992 for $\mathrm{PM}_{10}$ from uranium mill tailings areas on the facility revealed that concentrations of this pollutant in the air were well below EPA-established limits. The Air Particulates subsection of this report contains a more detailed discussion of these sampling results.

\section{Environmental Sampling for Nonradiological Pollution}

In addition to effluent sampling, environmental sampling of surface water for nonradiological pollutants was conducted on and near the GJPO facility. The sampling program is described in the Environmental Program Information section of this document. Also contained in that section is a comparison of measured constituent levels with state surface water quality standards. During the 1992 sampling period, only the standards for manganese and sulfate were exceeded in the Gunnison River, and these excessive values were not a result of GJPO/GJPORAP activities. 
SARA, Title III, Reporting

No SARA, Title III, reporting or notification occurred during 1992. A self-assessment of the DOE-GJPO's management of substances regulated by this act is currently being conducted. 


\section{Ground-Water Protection Program}

\section{Hydrogeology}

Two hydrogeologic units are of importance at the GJPO facility: the unconsolidated alluvial aquifer along the Gunnison River and the underlying Morrison Formation aquitard. These two units and the Gunnison River are the controlling factors in ground-water flow and discharge into the river.

The alluvial aquifer underlying the GJPO facility occupies about 22.8 hectares (56.4 acres) of the Gunnison River floodplain; its thickness ranges from 6 to 21 meters ( 20 to 70 feet) but averages between 6 and 8 meters ( 20 and 25 feet). Bounded on the west and north by the river and on the east by the shales and sandstones of the Morrison Formation, the aquifer is open to the south where the alluvium continues along the east boundary of the river. Recharge is mainly from fluctuations in the river and, to a much lesser extent, precipitation. Ground water is discharged into the Gunnison River along the north and west boundaries of the facility. Aquifer pump tests show the hydraulic conductivity of the alluvium to be approximately 9 meters ( $30 \mathrm{feet}$ ) per day and the specific yield to be on the order of 0.05 . Currently, the alluvial ground water is not used for any purpose.

The alluvial aquifer consists of two facies: a poorly sorted, unconsolidated basal gravel unit with a silt and sand matrix and an overlying unit of silty sand (Figure 8). Drill-hole logs from 1984 well installations indicate that both units are laterally continuous throughout the GJPO site.

Field observations suggest that a simple depositional model is adequate to represent the alluvial unit. The basal unit was deposited as the river migrated from the east to its present position. During this migration, older alluvial sediments to the west were eroded, and a new layer of sediment was left behind. This resulted in a continuous layer of gravel, sand, and silt. Periodic flood events deposited sand and silt on top of the gravels to produce the alluvial stratigraphy shown in Figure 8. Such a depositional model is similar to the fluvialfloodplain facies model of Allen (1970), the primary difference between the two being that the alluvium at the GJPO facility was deposited in a laterally more restricted and much higher energy environment. The result is a thicker and more consistent basal gravel unit.

Generally, ground water enters the alluvial aquifer as recharge from the Gunnison River along the southern perimeter of the GJPO facility. The upgradient ground water tends to exhibit water quality characteristics similar to those of the river, although major ion concentrations increase slightly as the ground-water residence time increases. Before uranium mill tailings were removed from the facility, ground water flowing beneath the facility became contaminated with the leached products of uranium mill tailings uranium, arsenic, selenium, and molybdenum - and major ion concentrations increased significantly. Only uranium and molybdenum, however, were mobile enough to migrate to the northern discharge boundary of the aquifer. 


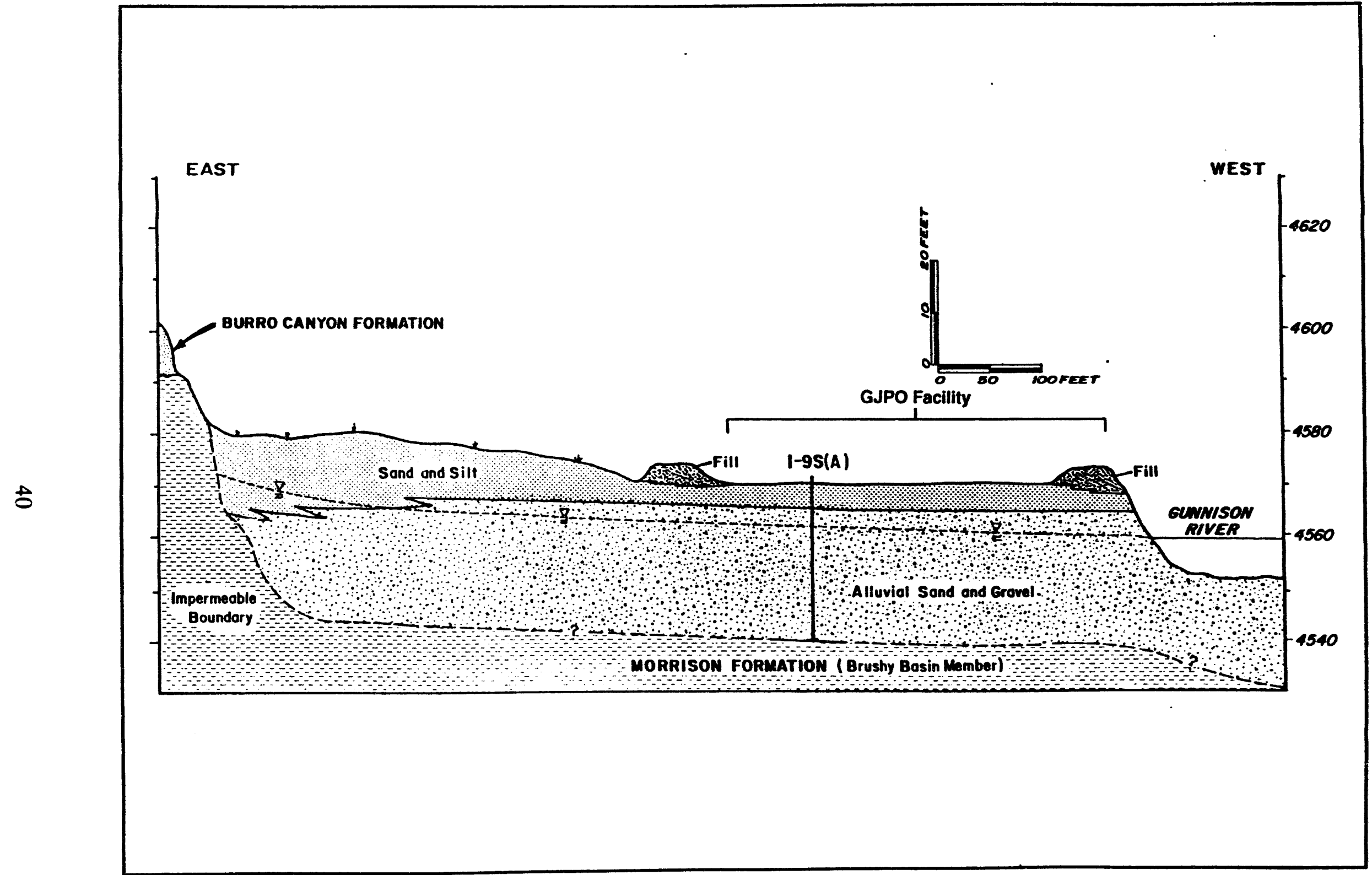

Figure 8. Geological Cross Section of the Alluvial Aquifer at the GJPO Facility 
Underlying the alluvial aquifer at the GJPO facility is the Morrison Formation, which, in the Grand Junction area, comprises the Brushy Basin and Salt Wash Members. The formation is composed primarily of red, green, and gray shale, although minor lenticular sandstones are present in the upper Brushy Basin, and increasing sandstone facies occur in the Salt Wash. The Morrison serves as an aquitard beneath the facility, as it inhibits downward ground-water flow and prevents communication between the overlying alluvial aquifer and the underlying Entrada Sandstone aquifer.

Regionally, the upper Brushy Basin Member is approximately 104 meters (340 feet) thick; however, about 12 meters ( 40 feet) of this unit has been removed from the GJPO facility site by the Gunnison River. Core samples from the facility show the Brushy Basin Member to contain mudstone ( 36 percent), siltstone ( 28 percent), shale ( 25 percent), and sandstone lenses (11 percent); a representative stratigraphic column is presented in Figure 9. Lohman (1965) reported that no known wells have been developed in the sandstones of the Brushy Basin, although some of the sandstone lenses bear small amounts of water.

At the base of the Brushy Basin is a conglomeratic sandstone which grades laterally into shale. The underlying Salt Wash Member is approximately 94 meters (310 feet) thick and contains lenticular sandstone units that produce minor amounts of water. Transmissivities measured in two producing wells in the Salt Wash ranged in value from 0.44 to 0.58 square meters (4.8 to 6.28 square feet) per day (Lohman 1965).

At the GJPO facility, the Gunnison River incises only the upper part of the Brushy Basin Member. Brushy Basin shales are exposed along the valley margins and underlie the alluvium. This framework results in free-flowing ground water in the alluvial aquifer because Brushy Basin shales act as a relatively impermeable boundary beneath the aquifer and along the valley margins.

\section{Ground Water Monitoring Program}

The objectives of the ground-water monitoring program at the GJPO are (1) to determine the baseline water quality and quantity conditions of the shallow alluvial aquifer underlying the site, (2) to characterize the type and extent of the contamination plume within the aquifer, (3) to verify compliance with federal and state ground water quality standards, and (4) to detect changes in water quality resulting from remedial action at the site. Although historical monitoring programs and characterization studies clearly defined baseline conditions with respect to inorganic constituents within the alluvial ground water, a characterization of organic constituents was not completed until 1992. Monitoring in 1992 focused on completing the organic characterization of the alluvial aquifer and pursuing the latter three monitoring objectives. Results of sample analyses were compared with federal standards promulgated by UMTRCA (40 CFR 192.12) and state standards promulgated by the Colorado Water Quality Control Act. The numeric standards applicable to the GJPO 


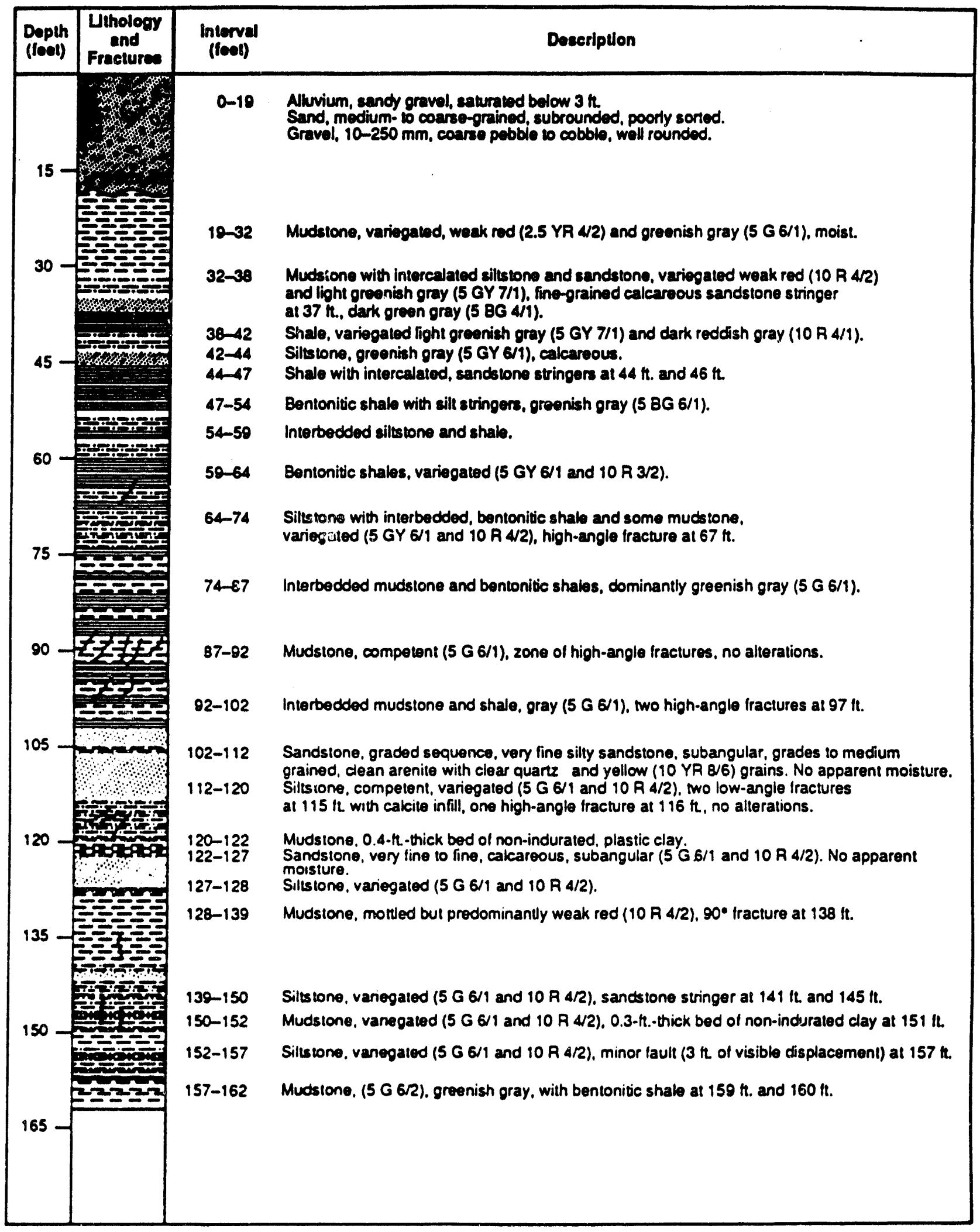

Figure 9. Representative Stratigraphic Column at the GJPO Facility (compiled from well log GJ87-19) 
site are listed in Table 8 (Table 8 combines federal and state standards into one list for comparison purposes; the more stringent standard was listed if a difference existed).

From January to May 1992, water levels in 18 wells completed in the alluvial aquifer (see Figure 10 for locations) were measured monthly, and water quality sumples were collected once in March. After this first sampling event, monitoring strategy and sampling methodology were revised. The revised strategy involved selecting a minimum number of wells located in strategic areas of the aquifer that would permit verification of ground-water restoration over time. Subsequently, the number of wells sampled during the June, September, and December sampling events was reduced from 18 to 13. The revision in sampling methodology involved the installation of dedicated bladder pumps, the use of which improved the sample quality and reduced the cost of the monitoring program. Well water levels continued to be measured monthly.

Two of the sampled wells, GJ84-9 and GJ84-10, are located upgradient from the mill tailings contamination plume and provide background water quality data. The remaining wells are located in or downgradient from contaminated/formerly contaminated areas of the facility and represent on-site and downgradient conditions.

Samples analyzed for radiological and inorganic constituents during the March sampling event were obtained with a peristaltic pump and filtered through a $0.45-\mu \mathrm{m}$ filter in line with the collection vessel; samples analyzed for organic constituents were obtained with a Teflon bailer. During the June, September, and December sampling events, all samples were collected using dedicated bladder pumps. Sampling procedures are outlined in the Environmental Procedures Catalog (Chem-Nuclear Geotech, Inc. 1992h), which incorporates the standard procedures published by EPA $(1985,1987)$ and the DOE (1987). Radiological analytes included gross alpha, radium-226, radium-228, uranium-234, uranium-238, thorium-230, and thorium-232. Inorganic analytes included arsenic, barium, calcium, cadmium, chloride, chromium, iron, potassium, magnesium, manganese, molybdenum, sodium, nitrate, lead, selenium, sulfate, vanadium, and total dissolved solids. Organic analytes included Target Compound List (TCL) volatiles, semivolatiles, pesticides/PCBs, and herbicides (see Table A-22, Appendix A, for TCL constituents). Total organic carbon was added to the analyte list in December after organic characterization was completed. Total alkalinity, temperature, $\mathrm{pH}$, and specific conductance were measured in the field to identify any change in general water quality. Analyses in 1992 did not include several constituents listed in Table 8, such as mercury and silver, because historically these constituents did not exceed standards.

Analytical results of samples collected from ground-water monitoring wells in 1992 are listed in Tables A-18 through A-21, A-23, and A-24 in Appendix A. Table 8 lists 1992 and historical maximum analyte concentrations and compares them with federal and state ground-water quality standards.

The highest uranium-234 and -238 activity recorded in $1992(1,131.51 \mathrm{pCi} / \mathrm{L})$ was measured in a sample from well 10-19N, located along the north boundary of the facility. Uranium activities above the UMTRCA standard of $30 \mathrm{pCi} / \mathrm{L}$ were recorded in samples from all the 


\section{Table 8. Comparison of Federal ${ }^{a}$ and State of Colorado ${ }^{b}$ Ground-Water Quality Standards with 1992 and Historical Maximum Concentrations in the Alluvial Aquifer ${ }^{\mathcal{c}}$}

\begin{tabular}{|c|c|c|c|c|c|c|c|c|}
\hline \multirow{2}{*}{ Constituent } & \multirow{2}{*}{\multicolumn{2}{|c|}{$\begin{array}{l}\text { Federal/State } \\
\text { Standard }\end{array}$}} & \multicolumn{3}{|c|}{1992 Maximad } & \multicolumn{3}{|c|}{ Historical Maximed,e } \\
\hline & & & Gradient & $\begin{array}{l}\text { On- } \\
\text { site }\end{array}$ & $\begin{array}{c}\text { Down- } \\
\text { Gradient }\end{array}$ & $\frac{\text { Up- }}{\text { Gredient }}$ & $\begin{array}{l}\text { On- } \\
\text { site }\end{array}$ & $\begin{array}{l}\text { Doin- } \\
\text { Gredient }\end{array}$ \\
\hline \multicolumn{9}{|l|}{ Inorganics } \\
\hline $\begin{array}{l}\text { Nitrate (as N)f } \\
\text { Total Dissolved } \\
\text { Sol ids } 9\end{array}$ & $\begin{array}{r}10 \\
2306\end{array}$ & $m g / L$ & $2180^{0.205}$ & $\begin{array}{l}35.916 \\
8840\end{array}$ & 6960 & $2040^{1.581}$ & $\begin{array}{l}69.573 \\
10200\end{array}$ & $6270^{2.711}$ \\
\hline \multicolumn{9}{|l|}{ Metals } \\
\hline $\begin{array}{l}\text { Arsenic } \\
\text { Barium } \\
\text { Cadmium } \\
\text { Chromium } \\
\text { Lead } \\
\text { Mercury } \\
\text { Molybdenum } \\
\text { Selenium } \\
\text { Silver }\end{array}$ & $\begin{array}{l}0.05 \\
1 \\
0.01 \\
0.05 \\
0.05 \\
0.002 \\
0.1 \\
0.01 \\
0.05\end{array}$ & $\begin{array}{l}\mathrm{mg} / \mathrm{L} \\
\mathrm{mg} / \mathrm{L} \\
\mathrm{mg} / \mathrm{L} \\
\mathrm{mg} / \mathrm{L} \\
\mathrm{mg} / \mathrm{L} \\
\mathrm{mg} / \mathrm{L} \\
\mathrm{mg} / \mathrm{L} \\
\mathrm{mg} / \mathrm{L} \\
\mathrm{mg} / \mathrm{L}\end{array}$ & $\begin{array}{l}<0.003 \\
-0.0127 \\
<0.001 \\
<0.006 \\
<0.001 \\
\cdots \\
\sim 0.0133 \\
-0.0025 \\
\cdots\end{array}$ & \begin{tabular}{l}
0.25 \\
-0.0627 \\
$<0.001$ \\
$<0.006$ \\
0.0571 \\
\hdashline. \\
0.434 \\
0.0917 \\
$\cdots$
\end{tabular} & $\begin{array}{l}0.0161 \\
-0.0264 \\
<0.001 \\
<0.006 \\
<0.001 \\
\cdots \\
0.304 \\
<0.02 \\
\cdots\end{array}$ & $\begin{array}{l}0.01 \\
-0.0098 \\
<0.002 \\
0.01 \\
<0.01 \\
<0.001 \\
0.023 \\
<0.01 \\
<0.01\end{array}$ & $\begin{array}{l}0.68 \\
0.4 \\
0.055 \\
0.112 \\
<0.01 \\
<0.001 \\
19 \\
0.685 \\
<0.01\end{array}$ & $\begin{array}{l}0.011 \\
-0.0277 \\
<0.002 \\
0.048 \\
<0.01 \\
<0.001 \\
0.413 \\
0.009 \\
<0.01\end{array}$ \\
\hline \multicolumn{9}{|l|}{ Radiological } \\
\hline $\begin{array}{l}\text { Gross Alpha (excluding } \\
\text { Radon and Uranium)h } \\
\text { Radium-226 and }-228 \\
\text { Thorium-230 and }-232 j \\
\text { Uranium-234 and }-238 \mathrm{k}\end{array}$ & $\begin{array}{r}15 \\
5 \\
60 \\
30\end{array}$ & $\begin{array}{l}p C i / L i \\
p C i / L \\
p C i / L \\
p C i / L\end{array}$ & $\begin{array}{c}<150 \\
0.1 \\
<1 \\
22.77\end{array}$ & $\begin{array}{c}1073.14 \\
\cdot 0.3 \\
18 \\
1131.51\end{array}$ & $\begin{array}{r}504.4 \\
0.1 \\
4.3 \\
995.6\end{array}$ & $\begin{array}{c}71.02 \\
1 \\
0.2 \\
199.8\end{array}$ & $\begin{array}{c}800.8 \\
36 \\
3.1 \\
5994\end{array}$ & $\begin{array}{r}234.2 \\
0.3 \\
1.7 \\
999\end{array}$ \\
\hline \multicolumn{9}{|l|}{ Merbicides } \\
\hline $\begin{array}{l}2,4,5-T P \text { (silvex) } \\
2,4-D\end{array}$ & $\begin{array}{r}10 \\
100\end{array}$ & $\begin{array}{l}\mu g / L \\
\mu g / L\end{array}$ & $\begin{array}{l}<0.2 \\
<0.25\end{array}$ & $\begin{array}{l}<0.2 \\
<0.25\end{array}$ & $\begin{array}{l}<0.2 \\
<0.25\end{array}$ & $\begin{array}{l}<0.17 \\
<1.2\end{array}$ & $\begin{array}{l}<0.17 \\
<1.2\end{array}$ & $\begin{array}{l}<0.17 \\
<1.2\end{array}$ \\
\hline \multicolumn{9}{|l|}{ Pesticides and PCBs } \\
\hline $\begin{array}{l}4,4^{\prime} \text {-DDT } \\
\text { Aldrin } \\
\text { Dieldrin } \\
\text { Endrin } \\
\text { Heptachlor } \\
\text { Heptachlor epoxide } \\
\text { Methoxychlor } \\
\text { Polychlorinated } \\
\text { biphenyls }\end{array}$ & $\begin{array}{c}0.1 \\
0.1 \\
0.1 \\
0.2 \\
0.1 \\
0.1 \\
100 \\
0.5\end{array}$ & $\begin{array}{l}\mu g / L \\
\mu g / L \\
\mu g / L \\
\mu g / L \\
\mu g / L \\
\mu g / L \\
\mu g / L \\
\mu g / L\end{array}$ & $\begin{array}{l}<0.1 \\
<0.05 \\
<0.1 \\
<0.1 \\
<0.05 \\
<0.05 \\
<0.5 \\
<2\end{array}$ & $\begin{array}{l}<0.1 \\
<0.052 \\
<0.1 \\
<0.1 \\
<0.052 \\
<0.052 \\
<0.52 \\
<2.1\end{array}$ & $\begin{array}{l}<0.1 \\
<0.05 \\
<0.1 \\
<0.1 \\
<0.05 \\
<0.05 \\
<0.5 \\
<2\end{array}$ & $\begin{array}{l}<0.1 \\
<0.05 \\
<0.1 \\
<0.1 \\
<0.05 \\
<0.05 \\
<0.5 \\
<1\end{array}$ & $\begin{array}{l}<0.1 \\
<0.05 \\
<0.1 \\
<0.1 \\
<0.05 \\
<0.05 \\
<0.5 \\
<1\end{array}$ & $\begin{array}{l}<0.1 \\
<0.05 \\
<0.1 \\
<0.1 \\
<0.05 \\
<0.05 \\
<0.5 \\
<1\end{array}$ \\
\hline $\begin{array}{l}\text { Toxaphene } \\
\text { gamma-BHC (Lindane) }\end{array}$ & $\begin{array}{l}5 \\
4\end{array}$ & $\begin{array}{l}\mu g / L \\
\mu g / L\end{array}$ & $\begin{array}{l}<5 \\
<0.05\end{array}$ & $\begin{array}{l}<5.2 \\
<0.052\end{array}$ & $\begin{array}{l}<5 \\
<0.05\end{array}$ & $\begin{array}{l}<1 \\
<0.05\end{array}$ & $\begin{array}{l}<1 \\
<0.05\end{array}$ & $\begin{array}{l}<1 \\
<0.05\end{array}$ \\
\hline
\end{tabular}

astandards from the Uranium Mill Tailings Radiation Control Act, revised in 1986.

bColorado Department of Health Water Quality Control Division, Basic Standards for Ground Water. "Potentially Usable Quality" classification, revised 10/17/91. Only the standards associated with constituents measured at the GJPO are listed in this table.

$c_{A} 11 . . .1$ indicates no data available; "<" indicates that the maximum concentration was below detection limits (number shown is detection (imit); " " indicates an approximate value (the value was outside the limits for which the instrument was calibrated).

dihe values are in units shown under the standards column.

eBased on maximun concentrations observed from 1984 through 1991.

$f_{N i t r a t e}\left(a s N\right.$ ) was derived for measured nitrate using the conversion: Nitrate (as $N$ ) $=\mathrm{NO}_{3}+4.427$.

gThis is a site-specific standard calculated as background $\times 1.25$. The background value is based on two sampling events in 1992.

hMeasured values represent total gross alpha minus uranium activity using assumptions in footnote $j$.

$i_{1} \mathrm{PCi} / \mathrm{L}=3.7 \times 10^{-2}$ becquerels $/ L$.

jHistorical measurements are for thorium-230 only.

kUranium concentrations measured in $\mathrm{mg} / \mathrm{L}$. were converted to $\mathrm{pCi} / \mathrm{L}$ for comparison purposes. The conversion assumes equilibrium and an activity of $0.666 \mathrm{pCi} / \mu \mathrm{g}$.

lpolychlorinated biphenyls include Aroclor 1016, 1221, 1232, 1242, 1248, 1254, and 1260. 


\section{Table 8 (continued). Comparison of Federal ${ }^{a}$ and State of Colorado ${ }^{b}$ Ground-Water Quality Standards with 1992 and Historical Maximum \\ Concentrations in the Alluvial Aquifer}

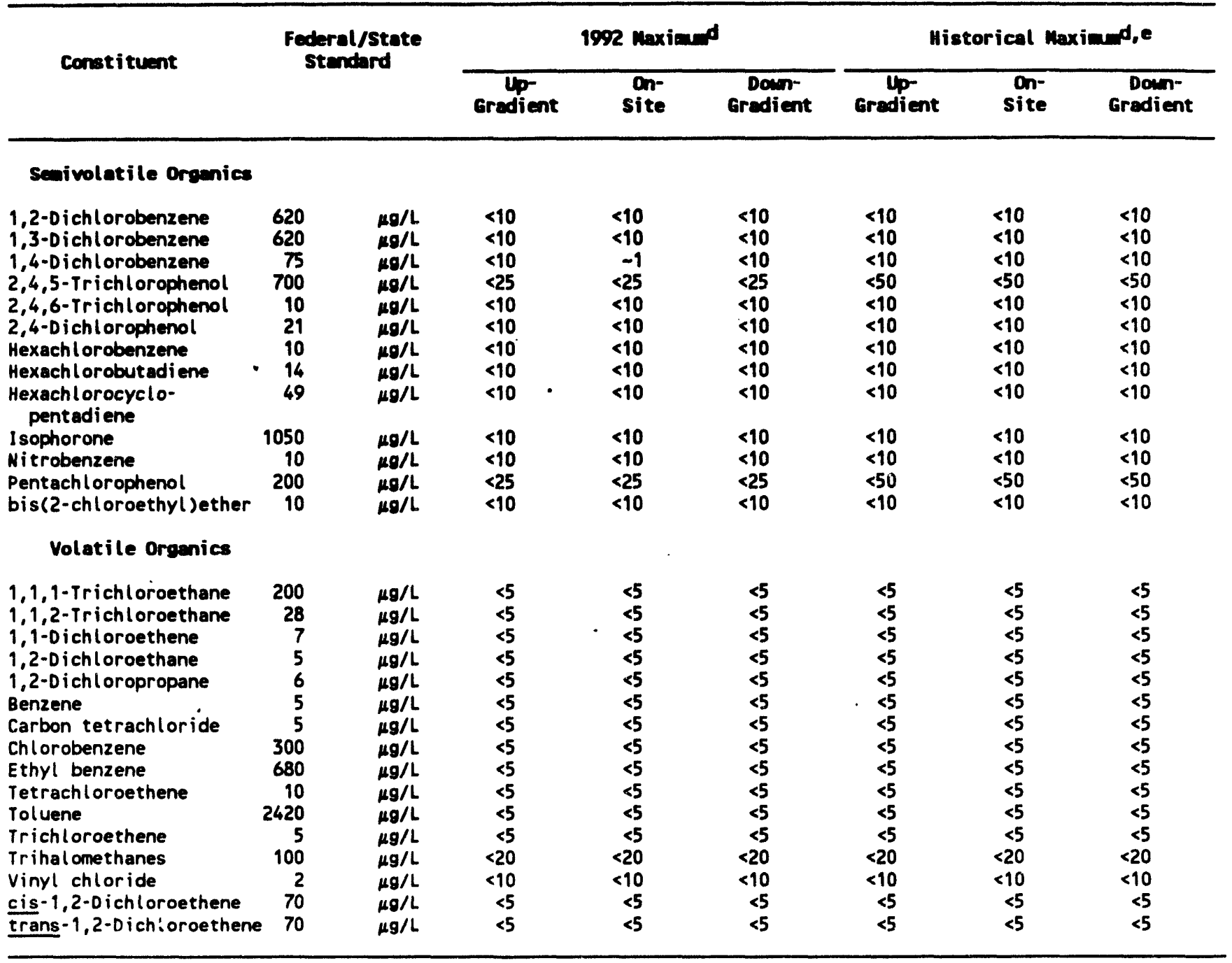

astandards from the Uranium Mill Tailings Radiation Control Act, revised in 1986.

bcolorado Department of Heal th Hater Quality Control Division, Basic Standards for.Ground Water. "Potentially Usable Quality" classification, revised 10/17/91. Only the standards associated with constituents measured at the GJPO are listed in this table.

$c_{A} 1$..." indicates no data available; a "<" indicates that the maximum concentration was below detection limits (number shown is detection limit); a " " indicates an approximate value (the value was outside the limits for which the instrument was calibrated).

dThe values are in units shown under the standards column.

eBased on maximum concentrations observed from 1984 through 1991. 


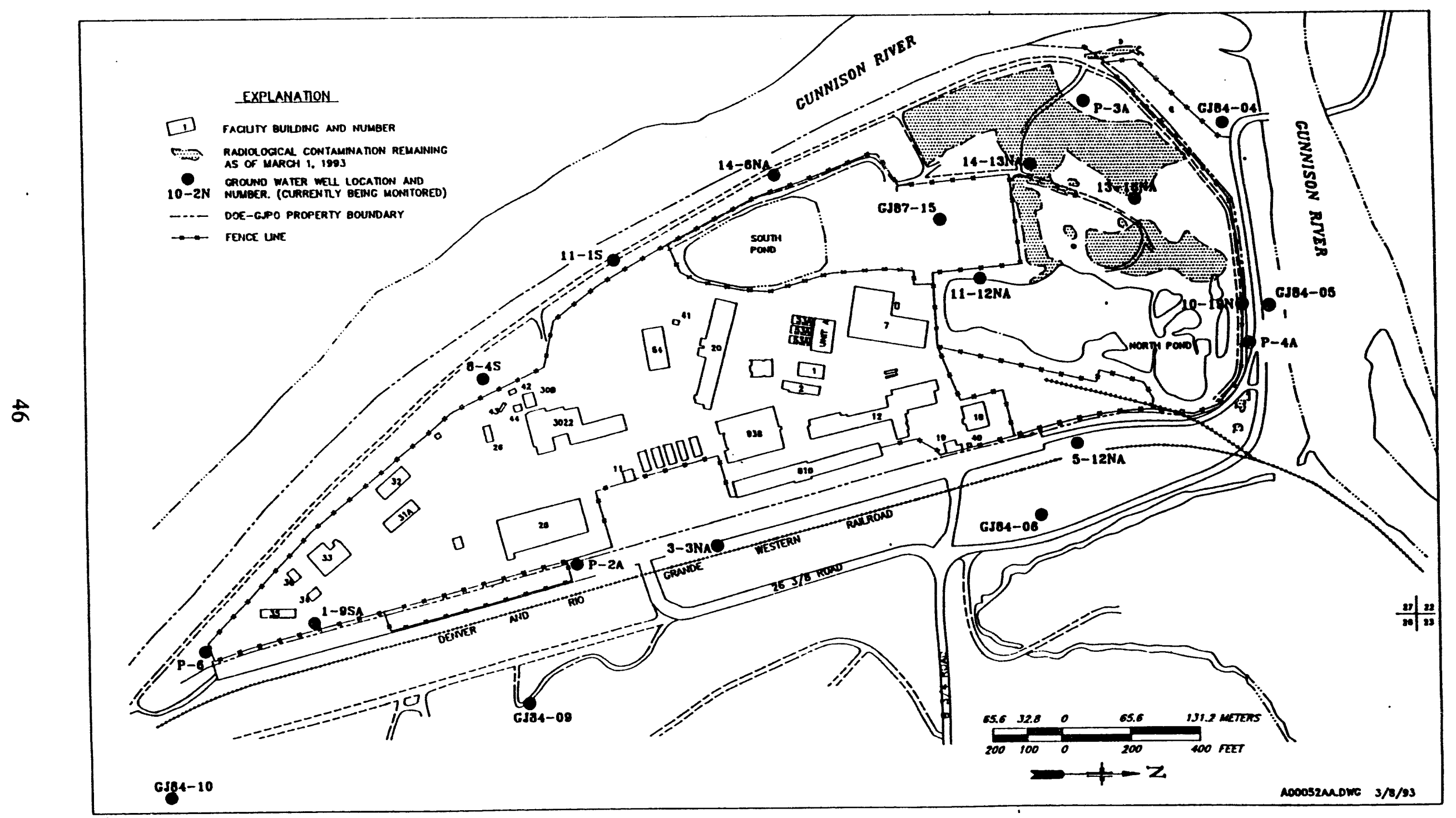

Figure 10. Ground-Water Sampling Locations at the GJPO Facility 
alluvial wells at some time during the year, except for the two background wells (GJ84-9, GJ84-10) and wells 1-9SA, P-2A, and P-6, which are located in the southeast (nearest-toupgradient) corner of the facility (Figure 11). A concentration contour map for uranium is shown in Figure 12 and illustrates the widespread uranium contamination.

Time-concentration graphs of uranium in samples collected from wells $10-19 \mathrm{~N}$ and 14-6NA from December 1986 to December 1992 are in Appendix B, Figures B-8 and B-9. Well 10-19N consistently yielded samples containing the highest concentrations of uranium, whereas well 14-6NA yielded samples containing typical concentrations of uranium. For comparison, background uranium concentrations in well GJ84-10 for the same time period are illustrated in Figure B-10.

Molybdenum contamination also was widespread with the highest concentration in 1992 $(0.434 \mathrm{mg} / \mathrm{L})$ occurring in well $11-1 \mathrm{~S}$. Samples from eight other wells yielded molybdenum concentrations in excess of the UMTRCA ground-water standard of $0.1 \mathrm{mg} / \mathrm{L}$ (Figure 11). Concentrations of molybdenum in samples collected from well 10-19N over the last 6 years are illustrated in Figure B-11. Figure B-12 shows concentrations of molybdenum, which generally are below the UMTRCA standard but above background, in samples collected from well 14-6NA. Background molybdenum concentrations are illustrated in Figure B-13.

Arsenic contamination was localized in the vicinity of buried tailings in 1992. A sample from well 14-6NA yielded the highest concentration of $0.250 \mathrm{mg} / \mathrm{L}$. The UMTRCA ground-water standard of $0.05 \mathrm{mg} / \mathrm{L}$ also was exceeded in samples from well GJ87-15 (Figure 11). As shown in Figure B-14, arsenic concentrations consistently exceed the UMTRCA standard over time in well 14-6NA. Background concentrations in well GJ84-10 are shown in Figure B-15 for comparison purposes.

Historically, radium-226 contamination appeared to be localized in the large buried tailings areas, which have now been remediated. In 1992, the state and UMTRCA radium-226 and -228 standard of $5 \mathrm{pCi} / \mathrm{L}$ was not exceeded in any well. Figure B-16 shows radium-226 concentrations over time in well 8-4S; background radium-226 concentrations are shown in Figure B-17.

Selenium contamination appeared in samples from wells P-2A, 13-16NA, 14-13NA, 8-4S, GJ87-15, 11-12NA, and 11-1S, which all yielded concentrations in excess of the UMTRCA ground-water standard of $0.01 \mathrm{mg} / \mathrm{L}$ (Figure 11). The highest selenium concentration, $0.0917 \mathrm{mg} / \mathrm{L}$, was recorded in a sample from well $8-4 \mathrm{~S}$. Samples from well 8-4S consistently have contained selenium concentrations exceeding the UMTRCA standard (Figure B-18). In contrast, samples from background well GJ84-10 typically contain concentrations beluw the standard (Figure B-19).

Nitrate also occurred in elevated concentrations on the facility. Samples containing concentrations in excess of the UMTRCA ground-water standard of $10.0 \mathrm{mg} / \mathrm{L}$ (nitrate as $\mathrm{N}$ ) were obtained from wells 11-1S and 8-4S (Figure 11). 


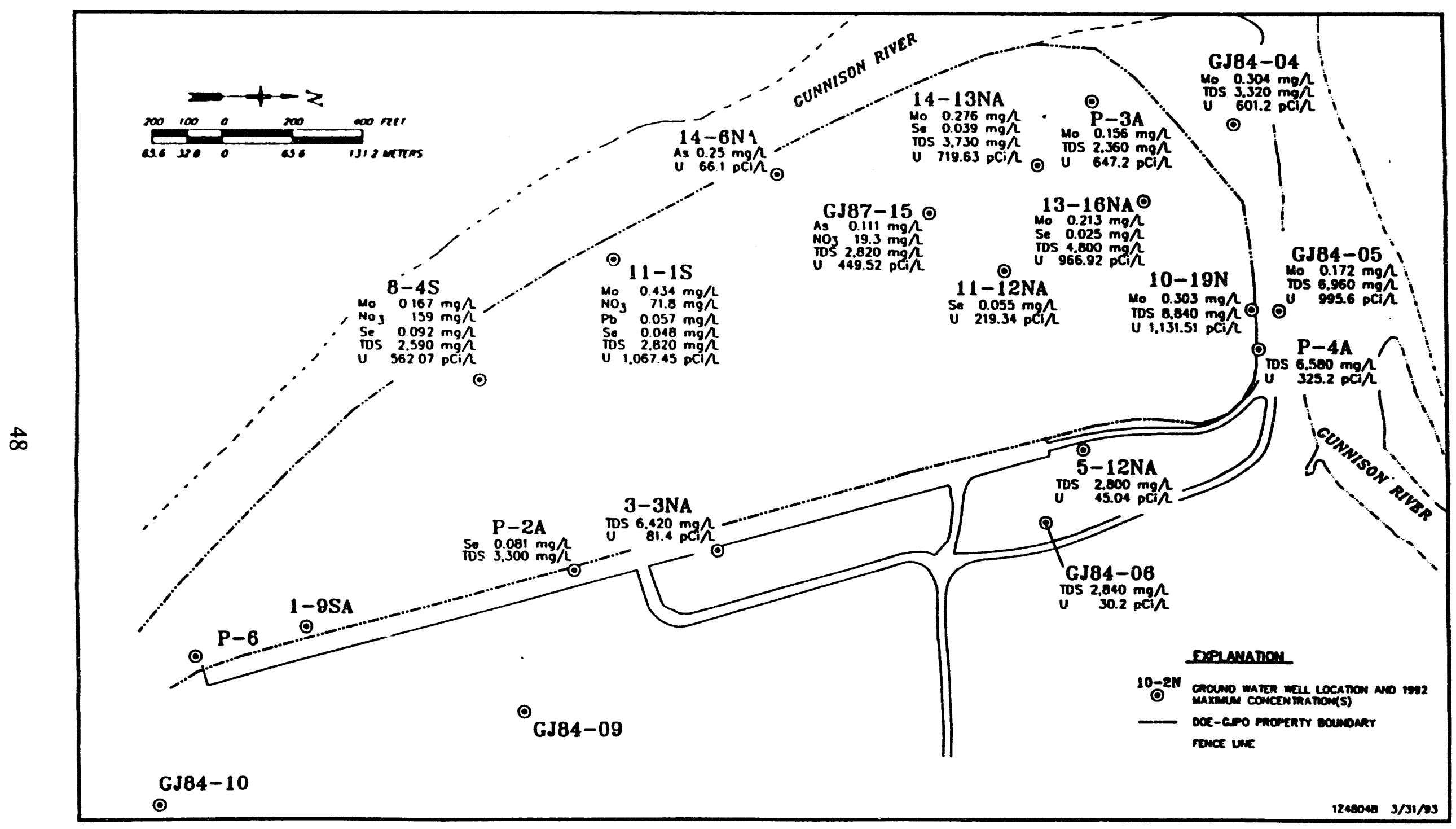

Figure 11. Concentrations of Ground-Water Analytes Exceeding Federal/State Standards in Alluvial Aquifer Well Samples at the GJPO 


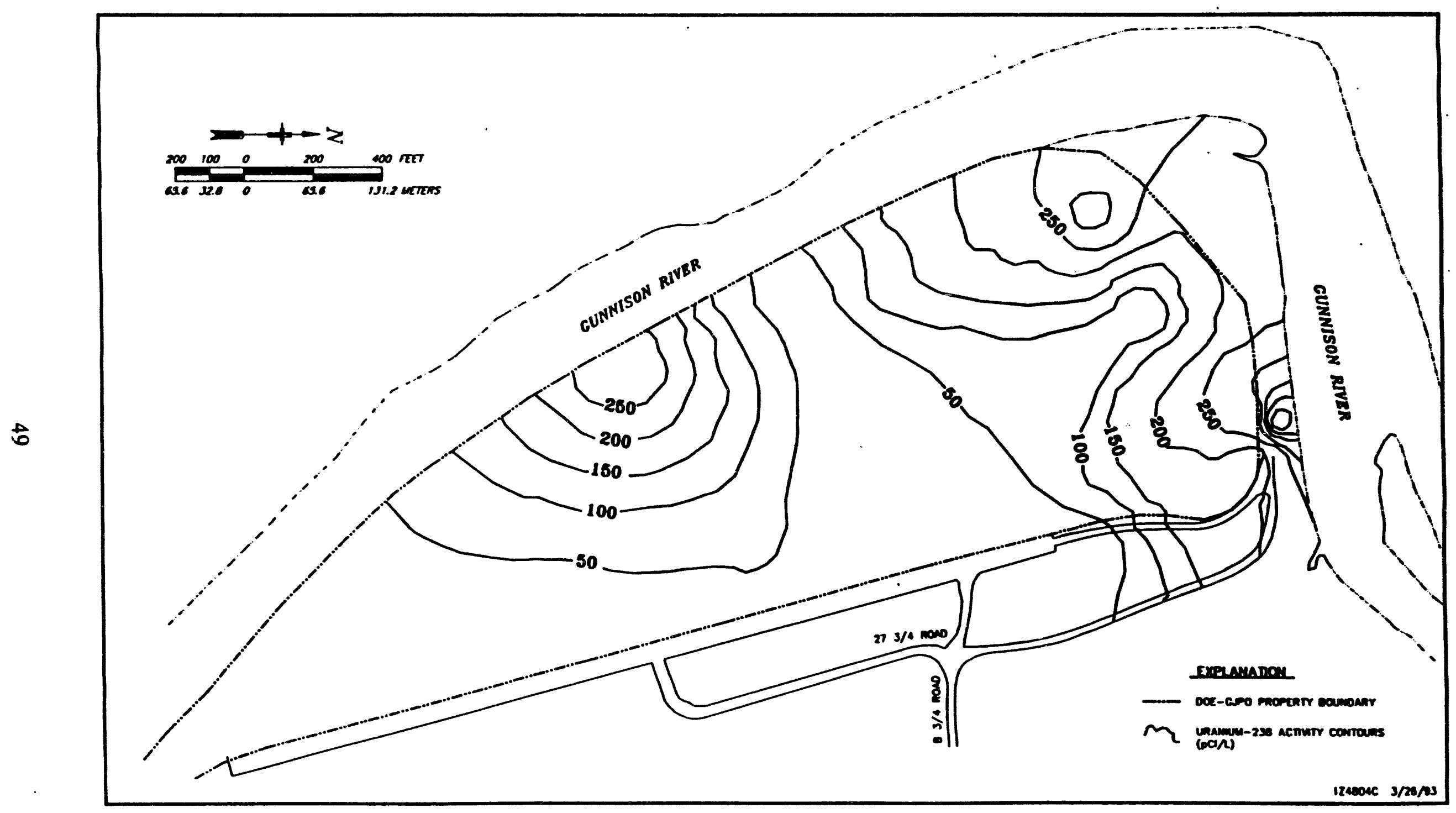

Figure 12. Uranium Activities in Ground Water at the GJPO in March 1992 
Lead contamination $(0.0571 \mathrm{mg} / \mathrm{L})$ in excess of the UMTRCA standard of $0.05 \mathrm{mg} / \mathrm{L}$ appeared in one sample from well 11-1S. Samples from all other wells contained concentrations below the standard.

Total dissolved solid (TDS) concentrations exceeded the aquifer-specific state standard of $2,306 \mathrm{mg} / \mathrm{L}$ (1.25 $\mathrm{x}$ background) in 15 wells (Figure 11). The highest TDS concentration in $1992,8,840 \mathrm{mg} / \mathrm{L}$, occurred in well $10-19 \mathrm{~N}$.

During 1992, concentrations of arsenic, lead, molybdenum, nitrate, selenium, TDS, uranium-234 and -238, and gross alpha in samples from the alluvial aquifer exceeded ground-water quality standards (Figure 11). Figures C-1 through C-4 in Appendix C identify which analytes exceeded their respective standards at each well during the 1992 quarterly sampling events. The objective of future monitoring is to verify improvement in ground-water quality when remedial action is completed. Ground-water modeling of the alluvial aquifer predicts that the ground water will be cleaned to below applicable standards within $\mathbf{5 0}$ to 80 years after the uranium mill tailings source is removed. Uranium mill tailings removal began on the facility in 1990 and will continue through 1994.

Sampling for TCL semivolatiles, volatiles, pesticides/PCBs, and herbicides in the alluvial aquifer was conducted in March, June, and September 1992. All measured concentrations were below reporting limits in all samples, with the exception of that for chloromethane, which was detected in a sample from well 11-1S in March (Table A-23). Because the low concentration of chloromethane $(10 \mu \mathrm{g} / \mathrm{L})$ from this sample was equal to the reporting limit, and chloromethane was detected in higher concentrations in the trip blanks $(61 \mu \mathrm{g} / \mathrm{L}$ and $30 \mu \mathrm{g} / \mathrm{L})$, it is likely the compound was introduced during the sampling and analysis process. Thus, it is not considered an actual ground-water contaminant.

Semivolatile compounds that were not TCL constituents, but were detected, were labeled as tentatively identified compounds and are listed in Tables A-23 and A-24 (note: no tentatively identified compounds were detected in the June sampling event). Tentatively identified compounds were labeled as such because the laboratory instrument was not calibrated for that specific compound, which resulted in an estimated concentration. Because the estimated concentrations were less than $48 \mu \mathrm{g} / \mathrm{L}$, these compounds are not considered potential contaminants in the ground water. 


\section{Quality Assurance}

DOE-GJPO has a Quality Assurance (QA) Program that is consistent with and responsive to DOE Order 5700.6C, Quality Assurance, and that addresses the requirements of the American Society of Mechanical Engineers NQA-1 (1989), Quality Assurance Program Requirements for Nuclear Facilities. This program provides a structured approach for the application of quality assurance (QA) principles for work performed by the DOE and is implemented through the Quality Assurance Manual (Chem-Nuclear Geotech, Inc. 1992i).

The Quality Assurance Program Plan (QAPP) was developed for specific environmental monitoring and surveillance needs at the GJPO and is appended to the Environmental Monitoring Plan (Chem-Nuclear Geotech, Inc. 1992j). The primary purposes of the QAPP are to ensure that all data and documentation are valid, traceable, and meet requirements and that all environmental monitoring results are valid. In addition, the QAPP addresses organizational responsibility, design, procedures, records, and audits. Field and laboratory quality control (QC), human factors, chain-of-custody, performance reporting, and independent data verification are addressed by the organizations responsible for the work.

\section{Sampling}

Sampling methodologies used for environmental monitoring at the GJPO are described in the Environmental Procedures Catalog (Chem-Nuclear Geotech, Inc. 1992h) and follow EPA guidance given in Test Methods for Evaluating Solid Waste (EPA 1986). QA and QC measures are integrated into all sampling activities and ensure sample representativeness, sample accuracy, sample precision, data comparability, and data completeness.

\section{Laboratory Analysis}

The Analytical Chemistry Laboratory performs analyses in support of the environmental monitoring programs and implements QA requirements through the Analytical Chemistry Laboratory Administrative Plan and Quality Control Procedures (Chem-Nuclear Geotech, lac. 1992k). The Analytical Chemistry Laboratory's objective is to provide high-quality analytical data that adequately meet the environmental monitoring program requirements. This objective is met by implementing laboratory protocol that ensures that a sample will retain its proper identity, that analytical results will be obtained and reported correctly, and that a well-documented sample history will be maintained. QA and QC measures addressed include organizational responsibility, training/qualification of personnel, laboratory records, records control, laboratory quality control, data acceptance, sample analysis, data recording and calculation, data deficiencies, chain-ofcustody, procurement of services, and quality assessment. Sampling and analytical 
methodologies are in the Analytical Chemistry Laboratory Handbook of Analytical and Sample-Preparation Procedures (Chem-Nuclear Geotech, Inc. 19921).

The Analytical Chemistry Laboratory maintains an internal QC organization to provide independent data review and evaluation of QA data. The QA section staff includes in its audit program the evaluation of the effectiveness of the Analytical Chemistry Laboratory QC program. Subcontracted analytical laboratories are under the supervision of the Analytical Chemistry Laboratory. It is the responsibility of the Analytical Chemistry Laboratory to monitor a subcontracted laboratory's methodologies and sample results and ensure that proper $\mathrm{QC}$ is practiced.

\section{Interlaboratory Quality Assurance Programs}

The Analytical Chemistry Laboratory participates in the DOE interlaboratory QA program coordinated by the DOE Environmental Measurements Laboratory (EML) for radioactive materials, as mandated by DOE Order 5400.1. This interlaboratory program is designed to test the quality of the environmental measurements being reported to the DOE by its contractors. Real or synthetic environmental samples that have been prepared and thoroughly analyzed at the program laboratory are distributed to the contractors for analysis, and the results are compiled for comparison. The Analytical Chemistry Laboratory also participates in two non-DOE interlaboratory QA programs: (1) EPA's Environmental Measurement Systems Laboratory (EMSL) for radioactive materials and (2) the National Institute for Occupational Safety and Health Proficiency Analytical Testing Program for airborne metal, silica, and asbestos. A summary of the 1992 Analytical Chemistry Laboratory's results for the EML and EMSL interlaboratory QA programs is in Table 9. The precision of the Laboratory's results can be determined by comparing the reported laboratory values with the reference values listed in Table 9 .

\section{Data Management}

Data management objectives for environmental monitoring activities are to maximize the usefulness and protection of important program information and to minimize the recordkeeping burden and cost. These objectives were achieved in 1992 through establishment and implementation of continuous, systematic, and effective controls for each phase of a record's life cycle. Records were stored and kept in an identifiable, legible, and retrievable state and were protected against deterioration, damage, and loss.

Data management activities included receipt of laboratory results via network transfer, data entry of information, and formatting of data for report preparation. All environmental monitoring data were stored in an ORACLE data base on a MicroVAX computer system that is maintained by Geotech.

Records generated in support of environmental monitoring activities were subject to the requirements for maximum-level records, as specified in the Environmental Monitoring Plan (Chem-Nuclear Geotech, Inc. 1992j) and in Section 13 of Geotech's Management Policies Manual (Chem-Nuclear Geotech, Inc. 1992m). 
Table 9. Summary of Analytical Results for the Interlaboratory Quality Assurance Programs

\begin{tabular}{|c|c|c|c|c|c|c|c|c|c|c|c|}
\hline $\begin{array}{l}\text { Anolysis } \\
\text { Date }\end{array}$ & $\begin{array}{l}\text { Matrix } \\
\text { Type }\end{array}$ & $\begin{array}{l}\text { Isotope } \\
\text { Anal yzed }\end{array}$ & $\begin{array}{l}\text { Reported } \\
\text { Laboratory } \\
\text { Value }\end{array}$ & $\begin{array}{l}\text { Reference } \\
\text { Value }\end{array}$ & $\begin{array}{l}\text { Ratio } \\
\text { Reported } \\
\text { Reference }\end{array}$ & $\begin{array}{c}\text { Anglysis } \\
\text { Date }\end{array}$ & $\begin{array}{l}\text { Detrix } \\
\text { Type }\end{array}$ & $\begin{array}{l}\text { Isotope } \\
\text { Amelyzed }\end{array}$ & $\begin{array}{l}\text { Reported } \\
\text { Lboratory } \\
\text { velue }\end{array}$ & $\begin{array}{l}\text { Reference } \\
\text { Value }\end{array}$ & $\begin{array}{l}\text { Datio } \\
\text { Reporteds } \\
\text { Referesce }\end{array}$ \\
\hline
\end{tabular}

DOE Environmental Measurements Laboratory



Envirormental Monitoring Systens Leboratory

all values are relative. Exponents are not included; therefore, values do not indicate actual concentrations. 


\section{References}

Allen, J. R. L., 1970. Physical Processes of Sedimentation, American Elsevier Publishing Company, New York, N.Y.

American Society of Mechanical Engineers NQA-1, 1989. Quality Assurance Program Requirements for Nuclear Facilities, The American Society of Mechanical Engineers, United Engineering Center, New York, NY.

Chem-Nuclear Geotech, Inc., 1992a. Conditionally Exempt Small Quantity Generator Management Plan, prepared for the U.S. Department of Energy, Grand Junction Projects Office, Grand Junction, CO.

, 1992b. Final Draft Environmental Assessment of Facility Operations at the Grand Junction Projects Office, prepared for the U.S. Department of Energy, Grand Junction Projects Office, Grand Junction, CO.

, 1992c. Environmental Protection Manual, prepared for the U.S. Department of Energy, Grand Junction Projects Office, Grand Junction, CO.

, 1992d. Grand Junction Projects Office U.S. Department of Energy Baseline Environmental Audit Action Plan, prepared for the U.S. Department of Energy, Grand Junction Projects Office, Grand Junction, CO.

, 1992e. Waste Minimization and Pollution Prevention Aw'areness Plan, prepared for the U.S. Department of Energy, Grand Junction Projects Office. Grand Junction, $\mathrm{CO}$.

Repon for Calendar Year 1991, prepared for the U.S. Department of Energy, Grand Junction Projects Office, Grand Junction, CO.

, 1992g. Grand Junction Projects Office Facility, Grand Junction Projects Office Remedial Action Project, Monticello Mill Tailings Site Sampling and Analysis Plan for Environmental Monitoring, prepared for the U.S. Department of Energy, Grand Junction Projects Office, Grand Junction, CO.

Catalog (Manual 116), Grand Junction, CO.

.1992h (continualiy updated). Environmental Procedures 1992i (continually updated). Quality Assurance Manual (Manual 1(1), Quality Assurance Section, Grand Junction, CO. 
Chem-Nuclear Geotech, Inc., 1992j. Grand Junction Projects Office, Grand Junction Projects Office Remedial Action Project, Monticello Mill Tailings Site Environmental Monitoring Plan, prepared for the U.S. Department of Energy, Grand Junction Projects Office, Grand Junction, CO.

, 1992k (continually updated). Analytical Chemistry Laboratory Administrative Plan and Quality Control Procedures, Grand Junction, CO.

19921 (continually updated). Analytical Chemistry Laboratory Handbook of Analytical Sample-Preparation Procedures, Volumes I and II, Grand Junction, CO. (Manual 100), Grand Junction, CO. ,1992m (continually updated). Management Policies Manual Henwood, P., and C. Ridolfi, 1986. Radiologic Characterization of the U.S. Department of Energy Grand Junction Projects Office Facility, GJ-41, Bendix Field Engineering Corporation, prepared for the U.S. Department of Energy, Grand Junction Operations, Grand Junction, CO.

Lohman, S. W., 1965. Geology and Artesian Water Supply, Grand Junction, Colorado, U.S. Geological Society, Geological Survey Professional Paper 451 (prepared in cooperation with the Colorado Water Conservation Board).

McGinley, F. E., 1987. Historical Survey of the Grand Junction Projects Office Facility Hazardous (Nonradioactive) Wastes, prepared for UNC Technical Services, Inc., Grand Junction Operations, Grand Junction, CO.

, 1988. Addendum to "Historical Survey of the Grand Junction Projects Office Facility - Hazardous (Nonradioactive) Wastes," prepared for UNC Geotech, Grand Junction Operations, Grand Junction, CO.

UNC Geotech, 1989. Final Remedial Investigation/Feasibility Study - Environmental Assessment for the U.S. Department of Energy Grand Junction (Colorado) Projects Office Facility, UNC/GJGJRAP-1, prepared for U.S. Department of Energy, Surplus Facilities Management Program, Richland, WA.

U.S. Department of Energy, 1987. The Environmental Survey Manual, Appendix E, Vol. 4, DOE/EH-0053.

, 1991a. Environmental Audit of the Grand Junction Projects Office, DOE/EH-0207P, U.S. Department of Energy, Office of Environmental Audit, Washington, DC.

, 1991b. Environmental Regulatory Guide for Radiological Effluent Monitoring and Environmental Sunveillance, U.S. Department of Energy, Assistant Secretary for Environment, Safety, and Health, Washington, DC.

U.S. Environmental Protection Agency, 1985. Practical Guide for Groundwater Sampling, EPA/600/2-85-104. 
U.S. Environmental Protection Agency, 1986. Test Methods for Evaluating Solid Waste, SW846, Third Edition, November.

$\overline{\text { EPA } / 625 / 6-87 / 016 .}$

1987. Handbook - Groundwater, 


\section{Distribution List}

\section{Federal Elected Officials}

\section{U.S. Senators}

The Honorable Hank Brown

SH 528 Hart Senate Office Bldg.

Washington, DC 20510-0602

(202) 2245941

The Honorable Ben Nighthorse Campbell

U.S. Senate

Washington, DC 20510-0603

(202) 244-5852

\section{U.S. Congressman}

The Honorable Scott McInnis

U.S. House of Representatives

Washington, DC 20515-0603

(202) 225-4761

State Elected Omcials

\section{Governor}

The Honorable Roy Romer

State Capitol Bldg.

Denver, CO 80230

(303) 866-2471

State Senator

The Honorable Tilman Bishop

State Capitol Building

Denver, CO 80203

(303) 866-3077

State Representatives

The Honorable Tim Foster

District 54 - Mesa/Delta

State Capitol Building

Denver, CO 80203

(303) $866-2348$ or Keota Burke

Office of Senator Hank Brown 215 Federal Bldg., 400 Rood Avenue Grand Junction, CO 81501

(303) 245-9553

or Dee Jacobson

Office of Senator Ben Nighthorse

Campbell

143 Grand Ave., Suite No. E

Grand Junction, CO 81501

(303) 241-6631

or Pat Teck

Office of Congressman Scott

McInnis

327 N. Seventh St.

Grand Junction, CO 81501

(303) 245-7107 or 2697 G Road

Grand Junction, CO 81506

(303) $242-1273$ or 593 Village Way

Grand Junction, CO 81501

(303) $245-8440$ 
The Honorable Dan Prinster

District 55 - Mesa County

State Capitol Building

Denver, CO 80203

(303) 866-2908

\section{Local Omcials}

City of Grand Junction

City Hall

250 North Fifth Street

Grand Junction, CO 81501

(303) 244-1503

City Manager: Mr. Mark Achen

\section{County Omials}

Mesa County Commissioners

Mesa County Court House

Grand Junction, CO 81501

\section{State and Local Agencies}

Mr. W. A. Franz

Colorado Department of Health

Department of Radiation Control

222 South Sixth Street

Grand Junction, CO 81501

(303) 248-7164

Mr. David C. Shelton

Colorado Department of Health

Hazardous Material and

Waste Management Division

4210 East Eleventh Avenue

Denver, CO 80220

(303) $320-8333$

Mesa County Planning Department

750 Main Street

Grand Junction, CO 81501

Federal Agencies

Ms. Patricia Hull

Air, Radiation, and Toxics

U.S. Environmental Protection

Agency, Region VIII

999 18th Street, Suite 500

Denver, CO 80202-2466 or 1203 Gunnison Avenue

Grand Junction, CO 81501

(303) 241-5015

Mayor:

The Honorable Reford Theobold

City Council:

Ms. Linda Afman

Mr. Bill Bessinger

Mr. Jim Boughman

Mr. Ron Maupin

Mr. R.T. Mantlo

Mr. Dan Rosenthal

Commissioners:

Ms. Doralyn Genova $\quad$ (303) 244-1606

Mr. John Crouch

(303) 244-1605

Mr. Jim Spehar

(303) 244-1604

Mr. Howard Roitman

Colorado Department of Health

Hazardous Materials and Waste

Management

4210 East Eleventh Avenue

Denver, CO 80220

(303) $320-8333$

Mesa County Health Department

Environmental Health

515 Patterson Road

Grand Junction, CO 81505

(303) 244-1750

Mr. Tom Burns, Section Chief

Bureau of Hazardous Waste Management

U.S. Environmental Protection

Agency, Region VIII

999 18th Street, Suite 500

Denver, CO 80202-2466 
Mr. Elmer Chenault, Manger

Federal Facilities Compliance Office

U.S. Environmental Protection

Agency, Region VIII

999 18th Street, Suite 500

Denver, CO 80202-2466

\section{Additional Contacts}

\section{Ms. Audrey Berry}

Public Affairs Specialist

U.S. Department of Energy

Grand Junction Projects Office

P. O. Box 2567

Grand Junction, CO 81502

(303) 248-7727

\section{Mr. Joseph Virgona}

Project Manager

U.S. Department of Energy

Grand Junction Projects Office

P.O. Box 2567

Grand Junction, CO 81503

(303) 248-6006

Dr. James J. Szenasi

Deputy Assistant Manager

U.S. Department of Energy

Office of Energy and Special Programs

Albuquerque Field Office

P.O. Box 5400

Albuquerque, NM 87115-5400

Ms. Constance Soden

Director

Environmental Protection Division

U.S. Department of Energy

Office of Environment, Safety,

and Health

P.O. Box 5400

Albuquerque, NM 87115

Mr. Dennis L. Krenz

Assistant Manager

U.S. Department of Energy

Office of Environmental, Safe:; and Health

P.O. Box 5400

Albuquerque, NM 87115
Ms. Karen Scotti

Public Relations Director

RUST Geotech Inc.

P.O. Box 14000

Grand Junction, CO 81502

(303) 248-6403

Mr. James E. Bickel

Assistant Manager

U.S. Department of Energy

Office of Energy and Special Programs

Albuquerque Field Office

P.O. Box 5400

Albuquerque, NM 87115-5400

(505) 845-4829

Mr. David Jackson

Public Affairs Officer

U.S. Department of Energy

Office of Intergovernmental and

External Affairs (OIEA)

Albuquerque Field Office

P.O. Box 5400

Albuquerque, NM 87115-5400

(505) 845-5699

Mr. William (Skip) Harrell

Environmental Compliance Program

Manager

U.S. Departement of Energy

Office of Environment, Safety,

and Health

P.O. Box 5400

Albuquerque, NM 87115

Jacob W. Gatrell

U.S. Department of Energy

Office of Environmental Restoration

(EM-451)

1000 Independence Avenue, SW

Washington, DC 20585 
Ralph Lightner

Branch Chief

U.S. Department of Energy

Office of Environmental

Restoration (EM-45)

Division of Southwestern Area Programs

Germantown, MD 20585

Administrative Record/Information Repository

Technical Resource Center

Building 810, Room 162

2597 B 3/4 Road

Grand Junction, CO 81503

Mesa County Public Library

530 Grand Avenue

Grand Junction, CO 81501

(303) 248-6015 
Appendix A

Monitoring Data 
Table A-1. Radon Data for Grand Junction, First Quarter 1992

(Date Installed: 12/27/1991; Date Removed: 04/03/1992)

\begin{tabular}{|c|c|c|c|c|}
\hline $\begin{array}{l}\text { Sample } \\
\text { Location }\end{array}$ & $\begin{array}{l}\text { Detector } \\
\text { Number }\end{array}$ & $\begin{array}{c}\text { Reported } \\
\text { Radona } \\
\text { Concentration } \\
\text { (pCi/L) }\end{array}$ & $\begin{array}{l}\text { Corrected } \\
\text { Radonb } \\
\text { Concentration } \\
(\mathrm{pCi} / L)\end{array}$ & $\begin{array}{c}\text { Radon } \\
\text { Concentration } \\
(\mu \mathrm{Ci} / \mathrm{mL})\end{array}$ \\
\hline $\begin{array}{l}\text { RN-G-01 } \\
\text { RN-G-01 }\end{array}$ & $\begin{array}{l}3176826 \\
3176841\end{array}$ & $\begin{array}{l}0.3 \\
0.3\end{array}$ & $\begin{array}{l}0.4 \\
0.4\end{array}$ & $\begin{array}{l}4.0 E-10 \\
4.0 E-10\end{array}$ \\
\hline $\begin{array}{l}R N-G-03 \\
R N-G-03\end{array}$ & $\begin{array}{l}3176823 \\
3176836\end{array}$ & $\begin{array}{l}0.8 \\
0.4\end{array}$ & $\begin{array}{l}1.0 \\
0.4\end{array}$ & $\begin{array}{l}1.0 E-09 \\
4.0 E-10\end{array}$ \\
\hline $\begin{array}{l}R N-G-04 \\
R N-G-04\end{array}$ & $\begin{array}{l}3176824 \\
3176829\end{array}$ & $\begin{array}{l}1.1 \\
0.4\end{array}$ & $\begin{array}{l}1.3 \\
0.4\end{array}$ & $\begin{array}{l}1.3 E-09 \\
4.0 E-10\end{array}$ \\
\hline $\begin{array}{l}R N-G-05 \\
R N-G-05\end{array}$ & $\begin{array}{l}3176832 \\
3176835\end{array}$ & $\begin{array}{l}0.3 \\
0.3\end{array}$ & $\begin{array}{l}0.3 \\
0.4\end{array}$ & $\begin{array}{l}3.0 E-10 \\
4.0 E-10\end{array}$ \\
\hline $\begin{array}{l}R N-G-08 \\
R N-G-08\end{array}$ & $\begin{array}{l}3176830 \\
3176834\end{array}$ & $\begin{array}{r}<0.1 \\
1.0\end{array}$ & $\begin{array}{r}<0.1 \\
1.2\end{array}$ & $\begin{array}{r}<1.0 \mathrm{E}-10 \\
1.2 \mathrm{E}-09\end{array}$ \\
\hline $\begin{array}{l}R N-G-09 \\
R N-G-09\end{array}$ & $\begin{array}{l}3176818 \\
3176838\end{array}$ & $\begin{array}{l}0.8 \\
0.6\end{array}$ & $\begin{array}{l}1.0 \\
0.7\end{array}$ & $\begin{array}{l}1.0 \mathrm{E}-09 \\
7.0 \mathrm{E}-10\end{array}$ \\
\hline $\begin{array}{l}R N-G-10 \\
R N \cdots G-10\end{array}$ & $\begin{array}{l}3176820 \\
3176831\end{array}$ & $\begin{array}{l}0.3 \\
0.5\end{array}$ & $\begin{array}{l}0.3 \\
0.6\end{array}$ & $\begin{array}{l}3.0 E-10 \\
6.0 E-10\end{array}$ \\
\hline $\begin{array}{l}\mathrm{RN}-\mathrm{G}-17 \\
\mathrm{RN}-\mathrm{G}-17\end{array}$ & $\begin{array}{l}3176851 \\
3176854\end{array}$ & $\begin{array}{l}0.4 \\
0.6\end{array}$ & $\begin{array}{l}0.5 \\
0.7\end{array}$ & $\begin{array}{l}5.0 E-10 \\
7.0 E-10\end{array}$ \\
\hline $\begin{array}{l}R N-G-18 \\
R N-G-18\end{array}$ & $\begin{array}{l}3176846 \\
3176863\end{array}$ & $\begin{array}{l}0.1 \\
0.5\end{array}$ & $\begin{array}{l}0.1 \\
0.6\end{array}$ & $\begin{array}{l}1.0 E-10 \\
6.0 E-10\end{array}$ \\
\hline $\begin{array}{l}R N-G-19 \\
R N-G-19\end{array}$ & $\begin{array}{l}3176843 \\
3176868\end{array}$ & $\begin{array}{l}0.4 \\
0.3\end{array}$ & $\begin{array}{l}0.5 \\
0.3\end{array}$ & $\begin{array}{l}5.0 E-10 \\
3.0 E-10\end{array}$ \\
\hline $\begin{array}{l}R N-G-23 \\
R N-G-23\end{array}$ & $\begin{array}{l}3176845 \\
3176856\end{array}$ & $\begin{array}{l}0.7 \\
0.2\end{array}$ & $\begin{array}{l}0.8 \\
0.2\end{array}$ & $\begin{array}{l}8.0 E-10 \\
2.0 E-10\end{array}$ \\
\hline $\begin{array}{l}R N-G-24 \\
R N-G-24\end{array}$ & $\begin{array}{l}3176848 \\
3176857\end{array}$ & $\begin{array}{l}0.5 \\
0.6\end{array}$ & $\begin{array}{l}0.6 \\
0.7\end{array}$ & $\begin{array}{l}6.0 E-10 \\
7.0 E-10\end{array}$ \\
\hline $\begin{array}{l}R N-G-25 \\
R N-G-25\end{array}$ & $\begin{array}{l}3176865 \\
3176866\end{array}$ & $\begin{array}{l}0.4 \\
0.2\end{array}$ & $\begin{array}{l}0.5 \\
0.3\end{array}$ & $\begin{array}{l}5.0 E-10 \\
3.0 E-10\end{array}$ \\
\hline
\end{tabular}

aThe reported radon concentration value is the result received from the subcontracted laboratory. A "<" indicates that the maximum concentration was below detection limits (number shown is detection limit).

bThe corrected radon concentration value is derived by applying a correction factor to the reported value. The correction factor is the ratio of a known exposure value to the value that is measured and reported. 
Table A-2. Radon Data for Grand Junction, Second Quarter 1992

(Date Installed: 04/03/1992; Date Removed: 06/29/1992)

\begin{tabular}{|c|c|c|c|c|}
\hline $\begin{array}{l}\text { Sample } \\
\text { Location }\end{array}$ & $\begin{array}{l}\text { Detector } \\
\text { Number }\end{array}$ & $\begin{array}{c}\text { Reported } \\
\text { Radona } \\
\text { Concentration } \\
\text { (pCi/L) }\end{array}$ & $\begin{array}{l}\text { Corrected } \\
\text { Radonb } \\
\text { Concentration } \\
\text { (pCi/L) }\end{array}$ & $\begin{array}{c}\text { Radon } \\
\text { Concentration } \\
(\mu \mathrm{Ci} / \mathrm{mL})\end{array}$ \\
\hline $\begin{array}{l}R N-G-01 \\
R N-G-01\end{array}$ & $\begin{array}{l}3176905 \\
3176916\end{array}$ & $\begin{array}{l}0.9 \\
1.4\end{array}$ & $\begin{array}{l}0.9 \\
1.4\end{array}$ & $\begin{array}{l}9.0 \mathrm{E}-10 \\
1.4 \mathrm{E}-09\end{array}$ \\
\hline $\begin{array}{l}R N-G-03 \\
R N-G-03\end{array}$ & $\begin{array}{r}3176910 \\
3176931\end{array}$ & $\begin{array}{l}0.6 \\
0.6\end{array}$ & $\begin{array}{l}0.6 \\
0.6\end{array}$ & $\begin{array}{l}6.0 \mathrm{E}-10 \\
6.0 \mathrm{E}-10\end{array}$ \\
\hline $\begin{array}{l}R N-G-04 \\
R N-G-04\end{array}$ & $\begin{array}{l}3176902 \\
3176913\end{array}$ & $\begin{array}{l}0.3 \\
0.9\end{array}$ & $\begin{array}{l}0.3 \\
0.9\end{array}$ & $\begin{array}{l}3.0 \mathrm{E}-10 \\
9.0 \mathrm{E}-10\end{array}$ \\
\hline $\begin{array}{l}R N-G-05 \\
R N-G-05\end{array}$ & $\begin{array}{l}3176896 \\
3176906\end{array}$ & $\begin{array}{l}1.0 \\
0.3\end{array}$ & $\begin{array}{l}1.0 \\
0.3\end{array}$ & $\begin{array}{l}1.0 \mathrm{E}-09 \\
3.0 \mathrm{E}-10\end{array}$ \\
\hline $\begin{array}{l}R N-G-08 \\
R N-G-08\end{array}$ & $\begin{array}{l}3176919 \\
3176922\end{array}$ & $\begin{array}{l}0.2 \\
0.8\end{array}$ & $\begin{array}{l}0.2 \\
0.8\end{array}$ & $\begin{array}{l}2.0 \mathrm{E}-10 \\
8.0 \mathrm{E}-10\end{array}$ \\
\hline $\begin{array}{l}R N-G-09 \\
R N-G-09\end{array}$ & $\begin{array}{l}3176927 \\
3176943\end{array}$ & $\begin{array}{l}1.3 \\
1.7\end{array}$ & $\begin{array}{l}1.3 \\
1.6\end{array}$ & $\begin{array}{l}1.3 \mathrm{E}-09 \\
1.6 \mathrm{E}-09\end{array}$ \\
\hline $\begin{array}{l}R N-G-10 \\
R N-G-10\end{array}$ & $\begin{array}{l}3176898 \\
3176917\end{array}$ & $\begin{array}{r}0.3 \\
<0.1\end{array}$ & $\begin{array}{r}0.3 \\
<0.1\end{array}$ & $\begin{array}{r}3.0 \mathrm{E}-10 \\
<1.0 \mathrm{E}-10\end{array}$ \\
\hline $\begin{array}{l}R N-G-17 \\
R N-G-17\end{array}$ & $\begin{array}{l}3176912 \\
3176925\end{array}$ & $\begin{array}{l}0.8 \\
0.5\end{array}$ & $\begin{array}{l}0.8 \\
0.5\end{array}$ & $\begin{array}{l}8.0 \mathrm{E}-10 \\
5.0 \mathrm{E}-10\end{array}$ \\
\hline $\begin{array}{l}R N-G-18 \\
R N-G-18\end{array}$ & $\begin{array}{l}3176932 \\
3176938\end{array}$ & $\begin{array}{l}0.3 \\
1.1\end{array}$ & $\begin{array}{l}0.3 \\
1.1\end{array}$ & $\begin{array}{l}\text { 3. } 0 \mathrm{E}-10 \\
1.1 \mathrm{E}-09\end{array}$ \\
\hline $\begin{array}{l}R N-G-19 \\
R N-G-19\end{array}$ & $\begin{array}{l}3176915 \\
3176933\end{array}$ & $\begin{array}{l}0.9 \\
0.6\end{array}$ & $\begin{array}{l}0.9 \\
0.6\end{array}$ & $\begin{array}{l}9.0 \mathrm{E}-10 \\
6.0 \mathrm{E}-10\end{array}$ \\
\hline $\begin{array}{l}R N-G-23 \\
R N-G-23\end{array}$ & $\begin{array}{l}3176907 \\
3176935\end{array}$ & $\begin{array}{l}0.3 \\
0.4\end{array}$ & $\begin{array}{l}0.3 \\
0.4\end{array}$ & $\begin{array}{l}3.0 \mathrm{E}-10 \\
4.0 \mathrm{E}-10\end{array}$ \\
\hline $\begin{array}{l}R N-G-24 \\
R N-G-24\end{array}$ & $\begin{array}{l}3176895 \\
3176911\end{array}$ & $\begin{array}{l}1.1 \\
0.4\end{array}$ & $\begin{array}{l}1.1 \\
0.4\end{array}$ & $\begin{array}{l}1.1 \mathrm{E}-09 \\
4.0 \mathrm{E}-10\end{array}$ \\
\hline $\begin{array}{l}R N-G-25 \\
R N-G-25\end{array}$ & $\begin{array}{l}3176918 \\
3176937\end{array}$ & $\begin{array}{l}0.4 \\
0.9\end{array}$ & $\begin{array}{l}0.4 \\
0.9\end{array}$ & $\begin{array}{l}4.0 \mathrm{E}-10 \\
9.0 \mathrm{E}-10\end{array}$ \\
\hline
\end{tabular}

aThe reported radon concentration value is the result received from the subcontracted laboratory. A " $<"$ indicates that the maximum concentration was below detection limits (number shown is detection limit).

bThe corrected radon concentration value is derived by applying a correction factor to the reported value. The correction factor is the ratio of a known exposure value to the value that is measured and reported. 
Table A-3. Radon Data for Grand Junction, Third Quarter 1992

(Date Installed: 06/29/1992; Date Removed: 09/28/1992)

\begin{tabular}{|c|c|c|c|c|}
\hline $\begin{array}{c}\text { Sample } \\
\text { Location }\end{array}$ & $\begin{array}{c}\text { Detector } \\
\text { Number }\end{array}$ & $\begin{array}{c}\text { Reported } \\
\text { Radona } \\
\text { Concentration } \\
\text { (pCi/L) }\end{array}$ & $\begin{array}{l}\text { Corrected } \\
\text { Radonb } \\
\text { Concentration } \\
\text { (pCi/L) }\end{array}$ & $\begin{array}{c}\text { Radon } \\
\text { Concentration } \\
(\mu \mathrm{Ci} / \mathrm{mL})\end{array}$ \\
\hline $\begin{array}{l}R N-G-01 \\
R N-G-01\end{array}$ & $\begin{array}{l}3557715 \\
3557731\end{array}$ & $\begin{array}{l}0.3 \\
0.5\end{array}$ & $\begin{array}{l}0.3 \\
0.5\end{array}$ & $\begin{array}{l}3.0 \mathrm{E}-10 \\
5.0 \mathrm{E}-10\end{array}$ \\
\hline $\begin{array}{l}R N-G-03 \\
R N-G-03\end{array}$ & $\begin{array}{l}3553210 \\
3557719\end{array}$ & $\begin{array}{l}0.8 \\
0.5\end{array}$ & $\begin{array}{l}0.9 \\
0.5\end{array}$ & $\begin{array}{l}9.0 \mathrm{E}-10 \\
5.0 \mathrm{E}-10\end{array}$ \\
\hline $\begin{array}{l}R N-G-04 \\
R N-G-04\end{array}$ & $\begin{array}{l}3553231 \\
3557722\end{array}$ & $\begin{array}{l}0.5 \\
0.4\end{array}$ & $\begin{array}{l}0.5 \\
0.4\end{array}$ & $\begin{array}{l}5.0 \mathrm{E}-10 \\
4.0 \mathrm{E}-10\end{array}$ \\
\hline $\begin{array}{l}R N-G-05 \\
R N-G-05\end{array}$ & $\begin{array}{l}3557718 \\
3557730\end{array}$ & $\begin{array}{l}0.7 \\
0.3\end{array}$ & $\begin{array}{l}0.8 \\
0.3\end{array}$ & $\begin{array}{l}\text { 8.0E-10 } \\
3.0 \mathrm{E}-10\end{array}$ \\
\hline $\begin{array}{l}R N-G-08 \\
R N-G-08\end{array}$ & $\begin{array}{l}3553215 \\
3553219\end{array}$ & $\begin{array}{l}0.3 \\
0.2\end{array}$ & $\begin{array}{l}0.4 \\
0.2\end{array}$ & $\begin{array}{l}4.0 E-10 \\
2.0 E-10\end{array}$ \\
\hline $\begin{array}{l}R N-G-09 \\
R N-G-09\end{array}$ & $\begin{array}{l}3553217 \\
3557714\end{array}$ & $\begin{array}{l}0.6 \\
0.6\end{array}$ & $\begin{array}{l}0.6 \\
0.6\end{array}$ & $\begin{array}{l}6.0 E-10 \\
6.0 E-10\end{array}$ \\
\hline $\begin{array}{l}R N-G-10 \\
R N-G-10\end{array}$ & $\begin{array}{l}3553227 \\
3557728\end{array}$ & $\begin{array}{l}0.6 \\
0.4\end{array}$ & $\begin{array}{l}0.6 \\
0.4\end{array}$ & $\begin{array}{l}6.0 E-10 \\
4.0 E-10\end{array}$ \\
\hline $\begin{array}{l}\mathrm{RN}-\mathrm{G}-17 \\
\mathrm{RN}-\mathrm{G}-17\end{array}$ & $\begin{array}{l}3553222 \\
3557725\end{array}$ & $\begin{array}{l}0.5 \\
0.4\end{array}$ & $\begin{array}{l}0.5 \\
0.4\end{array}$ & $\begin{array}{l}\text { 5. } 0 E-10 \\
4.0 E-10\end{array}$ \\
\hline $\begin{array}{l}R N-G-18 \\
R N-G-18\end{array}$ & $\begin{array}{l}3553206 \\
3557727\end{array}$ & $\begin{array}{l}0.7 \\
0.7\end{array}$ & $\begin{array}{l}0.8 \\
0.8\end{array}$ & $\begin{array}{l}8.0 E-10 \\
8.0 E-10\end{array}$ \\
\hline $\begin{array}{l}R N-G-19 \\
R N-G-19\end{array}$ & $\begin{array}{l}3553202 \\
3553211\end{array}$ & $\begin{array}{l}0.4 \\
0.4\end{array}$ & $\begin{array}{l}0.4 \\
0.4\end{array}$ & $\begin{array}{l}4.0 E-10 \\
4.0 E-10\end{array}$ \\
\hline $\begin{array}{l}R N-G-23 \\
R N-G-23\end{array}$ & $\begin{array}{l}3557716 \\
3557729\end{array}$ & $\begin{array}{l}0.3 \\
0.5\end{array}$ & $\begin{array}{l}0.4 \\
0.5\end{array}$ & $\begin{array}{l}4.0 E-10 \\
5.0 E-10\end{array}$ \\
\hline $\begin{array}{l}R N-G-24 \\
R N-G-24\end{array}$ & $\begin{array}{l}3553212 \\
3557732\end{array}$ & $\begin{array}{l}0.6 \\
0.8\end{array}$ & $\begin{array}{l}0.6 \\
0.9\end{array}$ & $\begin{array}{l}6.0 \mathrm{E}-10 \\
9.0 \mathrm{E}-10\end{array}$ \\
\hline $\begin{array}{l}R N-G-25 \\
R N-G-25\end{array}$ & $\begin{array}{l}3553204 \\
3553225\end{array}$ & $\begin{array}{l}0.8 \\
0.6\end{array}$ & $\begin{array}{l}0.9 \\
0.6\end{array}$ & $\begin{array}{l}9.0 E-10 \\
6.0 E-10\end{array}$ \\
\hline
\end{tabular}

aThe reported radon concentration value is the result received from the subcontracted laboratory.

bThe corrected radon concentration value is derived by applying a correction factor to the reported value. The correction factor is the ratio of a known exposure value to the value that is measured and reported. 
Table A-4. Radon Data for Grand Junction, Fourth Quarter 1992 (Date Installed: 09/28/1992; Date Removed: 12/28/1992)

\begin{tabular}{|c|c|c|c|c|}
\hline $\begin{array}{l}\text { Sample } \\
\text { Location }\end{array}$ & $\begin{array}{c}\text { Detector } \\
\text { Number }\end{array}$ & $\begin{array}{c}\text { Reported } \\
\text { Radona } \\
\text { Concentration } \\
(\mathrm{PC} i / L)\end{array}$ & $\begin{array}{l}\text { Corrected } \\
\text { Radonb } \\
\text { Concentration } \\
(\mathrm{PC} i / L)\end{array}$ & $\begin{array}{c}\text { Radon } \\
\text { Concentration } \\
(\mu \mathrm{Ci} / \mathrm{mL})\end{array}$ \\
\hline $\begin{array}{l}R N-G-03 \\
R N-G-03\end{array}$ & $\begin{array}{l}3557758 \\
3557773\end{array}$ & $\begin{array}{l}0.6 \\
0.5\end{array}$ & $\begin{array}{l}0.6 \\
0.5\end{array}$ & $\begin{array}{l}6.0 E-10 \\
5.0 E-10\end{array}$ \\
\hline $\begin{array}{l}R N-G-04 \\
R N-G-04\end{array}$ & $\begin{array}{l}3557759 \\
3557799\end{array}$ & $\begin{array}{l}0.4 \\
0.4\end{array}$ & $\begin{array}{l}0.4 \\
0.4\end{array}$ & $\begin{array}{l}4.0 \mathrm{E}-10 \\
4.0 \mathrm{E}-10\end{array}$ \\
\hline $\begin{array}{l}R N-G-05 \\
R N-G-05\end{array}$ & $\begin{array}{l}3557760 \\
3557766\end{array}$ & $\begin{array}{l}0.5 \\
0.5\end{array}$ & $\begin{array}{l}0.5 \\
0.5\end{array}$ & $\begin{array}{l}5.0 E-10 \\
5.0 E-10\end{array}$ \\
\hline $\begin{array}{l}R N-G-09 \\
R N-G-09\end{array}$ & $\begin{array}{l}3557764 \\
3557777\end{array}$ & $\begin{array}{l}0.7 \\
0.8\end{array}$ & $\begin{array}{l}0.7 \\
0.8\end{array}$ & $\begin{array}{l}\text { 7.0E-10 } \\
8.0 \mathrm{E}-10\end{array}$ \\
\hline $\begin{array}{l}R N-G-10 \\
R N-G-10\end{array}$ & $\begin{array}{l}3557761 \\
3557765\end{array}$ & $\begin{array}{r}1.0 \\
<0.1\end{array}$ & $\begin{array}{r}1.0 \\
<0.1\end{array}$ & $\begin{array}{r}1.0 \mathrm{E}-09 \\
<1.0 \mathrm{E}-10\end{array}$ \\
\hline $\begin{array}{l}\text { RN-G-17 } \\
\text { RN-G-17 }\end{array}$ & $\begin{array}{l}35 \$ 7779 \\
3557791\end{array}$ & $\begin{array}{l}0.2 \\
0.5\end{array}$ & $\begin{array}{l}0.2 \\
0.5\end{array}$ & $\begin{array}{l}2.0 \mathrm{E}-10 \\
5.0 \mathrm{E}-10\end{array}$ \\
\hline $\begin{array}{l}R N-G-18 \\
R N-G-18\end{array}$ & $\begin{array}{l}3557786 \\
3557796\end{array}$ & $\begin{array}{l}0.8 \\
0.8\end{array}$ & $\begin{array}{l}0.8 \\
0.8\end{array}$ & $\begin{array}{l}8.0 E-10 \\
8.0 E-10\end{array}$ \\
\hline $\begin{array}{l}R N-G-19 \\
R N-G-19\end{array}$ & $\begin{array}{l}3557793 \\
3557795\end{array}$ & $\begin{array}{l}0.6 \\
0.4\end{array}$ & $\begin{array}{l}0.6 \\
0.4\end{array}$ & $\begin{array}{l}6.0 \mathrm{E}-10 \\
4.0 \mathrm{E}-10\end{array}$ \\
\hline $\begin{array}{l}R N-G-23 \\
R N-G-23\end{array}$ & $\begin{array}{l}3557783 \\
3557787\end{array}$ & $\begin{array}{l}0.6 \\
0.2\end{array}$ & $\begin{array}{l}0.6 \\
0.2\end{array}$ & $\begin{array}{l}6.0 E-10 \\
2.0 E-10\end{array}$ \\
\hline $\begin{array}{l}R N-G-24 \\
R N-G-24\end{array}$ & $\begin{array}{l}3557778 \\
3557792\end{array}$ & $\begin{array}{l}0.3 \\
0.5\end{array}$ & $\begin{array}{l}0.3 \\
0.5\end{array}$ & $\begin{array}{l}3.0 \mathrm{E}-10 \\
5.0 \mathrm{E}-10\end{array}$ \\
\hline $\begin{array}{l}\mathrm{RN}-\mathrm{G}-25 \\
\mathrm{RN}-\mathrm{G}-25\end{array}$ & $\begin{array}{l}3557784 \\
3557798\end{array}$ & $\begin{array}{l}0.3 \\
0.4\end{array}$ & $\begin{array}{l}0.3 \\
0.4\end{array}$ & $\begin{array}{l}3.0 \mathrm{E}-10 \\
4.0 \mathrm{E}-10\end{array}$ \\
\hline
\end{tabular}

aThe reported radon concentration value is the result received from the subcontracted laboratory. A " $<$ " indicates that the maximum concentration was below detection limits (number shown is detection limit).

bThe corrected radon concentration value is derived by applying a correction factor to the reported value. The correction factor is the ratio of a known exposure value to the value that is measured and reported. 
Table A-5. Analytical Air Sample Results for Station AIR-G-1 during 1992a

\begin{tabular}{|c|c|c|c|c|c|c|c|c|c|c|c|c|c|}
\hline \multirow{2}{*}{$\begin{array}{l}\text { Sample } \\
\text { Location }\end{array}$} & \multirow{2}{*}{$\begin{array}{l}\text { Sample } \\
\text { Date }\end{array}$} & \multirow{2}{*}{$\begin{array}{l}\text { Ticket } \\
\text { Number }\end{array}$} & \multirow{2}{*}{$\begin{array}{l}\text { Filter } \\
\text { Number }\end{array}$} & \multirow{2}{*}{$\begin{array}{l}\text { Flow } \\
\text { Rate } \\
\text { (scfm) }\end{array}$} & \multirow{2}{*}{$\begin{array}{l}\text { Sample } \\
\text { Time } \\
\text { (hours) }\end{array}$} & \multicolumn{2}{|c|}{ Radium-226 } & \multicolumn{3}{|c|}{ Thorile-230 } & \multicolumn{3}{|c|}{ Uranien } \\
\hline & & & & & & $(\mathrm{pCi} / \mathrm{F})^{b}$ & $(\mu \mathrm{Ci} / \mathrm{ml})$ & $\overline{(p C i / F)}$ & $(\mu \mathrm{Ci} / \mathrm{L})$ & $\overline{(p g / \mu /)}$ & $(\mu g / F)^{c}$ & $\left(\mu g / m^{3}\right)$ & $(\mu \mathrm{ci} / \mathrm{Ll})$ \\
\hline $\begin{array}{l}\text { AIR-G-1 } \\
\text { AIR-G-1 } \\
\text { AIR-G-1 } \\
\text { AIR-G-1 } \\
\text { AIR-G-1 } \\
\text { AIR-G-1 } \\
\text { AIR-G-1 } \\
\text { AIR-G-1 } \\
\text { AIR-G-1 } \\
\text { AIR-G-1 } \\
\text { AIR-G-1 } \\
\text { AIR-G-1 }\end{array}$ & $\begin{array}{l}01 / 31 / 1992 \\
02 / 29 / 1992 \\
03 / 12 / 1992 \\
04 / 17 / 1992 \\
05 / 29 / 1992 \\
06 / 26 / 1992 \\
07 / 09 / 1992 \\
08 / 21 / 1992 \\
09 / 25 / 1992 \\
10 / 30 / 1992 \\
11 / 09 / 1992 \\
12 / 28 / 1992\end{array}$ & $\begin{array}{l}\text { MLY-673 } \\
\text { MLY-913 } \\
\text { MLY-922 } \\
\text { MLY-768 } \\
\text { MLY-867 } \\
M L Y-707 \\
M L Y-716 \\
M L Y-888 \\
09221992-01 \\
10261992-01 \\
11091992-01 \\
12281992-01\end{array}$ & $\begin{array}{r}5916046 \\
5916027 \\
5916018 \\
5918856 \\
5918832 \\
5918817 \\
5916387 \\
5916343 \\
5916299 \\
5916260 \\
5916251 \\
5916206\end{array}$ & $\begin{array}{l}37 \\
36.6 \\
36 \\
35 \\
34.5 \\
33.7 \\
33.6 \\
33.8 \\
34 \\
35 \\
36 \\
37\end{array}$ & $\begin{array}{r}96.67 \\
98.22 \\
99.92 \\
100.04 \\
78.21 \\
100.42 \\
100.11 \\
74.85 \\
77.30 \\
101.31 \\
177.37 \\
76.63\end{array}$ & $\begin{array}{r}<1.5 \\
1.1 \\
<2.2 \\
<2.9 \\
<2.4 \\
<2.2 \\
<1.8 \\
<2.9 \\
3.5 \\
<3.7 \\
0.7 \\
0.6\end{array}$ & $\begin{array}{r}<2.5 \mathrm{E}-16 \\
1.8 \mathrm{E}-16 \\
<3.6 \mathrm{E}-16 \\
<4.9 \mathrm{E}-16 \\
<5.2 \mathrm{E}-16 \\
<3.8 \mathrm{E}-16 \\
<3.1 \mathrm{E}-16 \\
<6.7 \mathrm{E}-16 \\
7.8 \mathrm{E}-16 \\
<6.1 \mathrm{E}-16 \\
6.5 \mathrm{E}-17 \\
1.2 \mathrm{E}-16\end{array}$ & $\begin{array}{r}0.6 \\
<0.6 \\
<0.6 \\
1.0 \\
<0.5 \\
1.2 \\
<0.5 \\
0.7 \\
0.7 \\
0.8 \\
0.5 \\
<0.3\end{array}$ & $\begin{array}{r}9.9 \mathrm{E}-17 \\
<9.8 \mathrm{E}-17 \\
<9.8 \mathrm{E}-17 \\
1.7 \mathrm{E}-16 \\
<1.1 \mathrm{E}-16 \\
2.1 \mathrm{E}-16 \\
<8.7 \mathrm{E}-17 \\
1.6 \mathrm{E}-16 \\
1.6 \mathrm{E}-16 \\
1.3 \mathrm{E}-16 \\
4.6 \mathrm{E}-17 \\
<6.2 \mathrm{E}-17\end{array}$ & $\begin{array}{r}5.1 E-09 \\
<5.1 \mathrm{E}-09 \\
<5.1 \mathrm{E}-09 \\
8.7 \mathrm{E}-09 \\
<5.6 \mathrm{E}-09 \\
1.1 \mathrm{E}-08 \\
<4.5 \mathrm{E}-09 \\
8.4 \mathrm{E}-09 \\
8.1 \mathrm{E}-09 \\
6.8 \mathrm{E}-09 \\
2.4 \mathrm{E}-09 \\
<3.2 \mathrm{E}-09\end{array}$ & $\begin{array}{l}2.7 \\
1.1 \\
1.0 \\
1.0 \\
1.2 \\
2.1 \\
1.1 \\
1.3 \\
1.4 \\
1.1 \\
1.2 \\
0.9\end{array}$ & $\begin{array}{l}4.4 E-04 \\
1.8 E-04 \\
1.6 E-04 \\
1.7 E-04 \\
2.6 E-04 \\
3.7 E-04 \\
1.9 E-04 \\
3.0 E-04 \\
3.1 E-04 \\
1.8 E-04 \\
1.1 E-04 \\
2.0 E-04\end{array}$ & $\begin{array}{l}3.0 E-16 \\
1.2 E-16 \\
1.1 E-16 \\
1.1 E-16 \\
1.7 E-16 \\
2.4 E-16 \\
1.3 E-16 \\
2.0 E-16 \\
2.1 E-16 \\
1.2 E-16 \\
7.4 E-17 \\
1.3 E-16\end{array}$ \\
\hline
\end{tabular}

$a_{A}$ "<" indicates that the maximum concentration was below detection limits (number shown is detection limit).

bpicocuries per filter.

cMicrograms per filter. 
Table A-6. Analytical Air Sample Results for Station AIR-G-2 during 1992a

\begin{tabular}{|c|c|c|c|c|c|c|c|c|c|c|c|c|c|}
\hline \multirow{2}{*}{$\begin{array}{l}\text { Sample } \\
\text { Location }\end{array}$} & \multirow{2}{*}{$\begin{array}{l}\text { Sample } \\
\text { Date }\end{array}$} & \multirow{2}{*}{$\begin{array}{l}\text { Ticket } \\
\text { Number }\end{array}$} & \multirow{2}{*}{$\begin{array}{l}\text { Filter } \\
\text { Number }\end{array}$} & \multirow{2}{*}{$\begin{array}{l}\text { Flow } \\
\text { Rate } \\
\text { (scfin) }\end{array}$} & \multirow{2}{*}{$\begin{array}{l}\text { Saiple } \\
\text { Time } \\
\text { (hours) }\end{array}$} & \multirow{2}{*}{\multicolumn{2}{|c|}{$\frac{\text { Radium-226 }}{(\mathrm{pCi} / \mathrm{F})^{\mathrm{b}}(\mu \mathrm{Ci} / \mathrm{m})}$}} & \multicolumn{3}{|c|}{ Thariin-230 } & \multicolumn{3}{|c|}{ Uranitu } \\
\hline & & & & & & & & $\overline{(p C i / f)}$ & $(\mu(i / \mu)$ & $\overline{(p g / m)}$ & $\overline{\varphi g / F}$ & $\left.g / m^{3}\right)$ & $(\mu \mathrm{Ci} / / L)$ \\
\hline $\begin{array}{l}\text { AIR-G-2 } \\
\text { AIR-G-2 } \\
\text { AIR-G-2 } \\
\text { AIR-G-2 } \\
\text { AIR-G-2 } \\
\text { AIR-G-2 } \\
\text { AIR-G-2 } \\
\text { AIR-G-2 } \\
\text { AIR-G-2 } \\
\text { AIR-G-2 } \\
\text { AIR-G-2 }\end{array}$ & $\begin{array}{l}01 / 31 / 1992 \\
02 / 29 / 1992 \\
03 / 12 / 1992 \\
05 / 29 / 1992 \\
06 / 26 / 1992 \\
07 / 10 / 1992 \\
08 / 21 / 1992 \\
09 / 25 / 1992 \\
10 / 30 / 1992 \\
11 / 09 / 1992 \\
12 / 28 / 1992\end{array}$ & $\begin{array}{c}M L Y-674 \\
M L Y-914 \\
M L Y-923 \\
M L Y-868 \\
M L Y-708 \\
M L Y-717 \\
M L Y-889 \\
09221992-02 \\
10261992-02 \\
11091992-02 \\
12281992-02\end{array}$ & $\begin{array}{l}5916045 \\
5916026 \\
5916017 \\
5918831 \\
5918816 \\
5916386 \\
5916342 \\
5916298 \\
5916259 \\
5916250 \\
5916205\end{array}$ & $\begin{array}{l}37 \\
36.6 \\
36 \\
34.5 \\
33.7 \\
33.6 \\
33.8 \\
34 \\
35 \\
36 \\
37\end{array}$ & $\begin{array}{r}95.37 \\
98.40 \\
99.23 \\
77.77 \\
100.43 \\
99.84 \\
74.80 \\
76.98 \\
100.56 \\
177.05 \\
76.10\end{array}$ & $\begin{array}{r}1.6 \\
12.9 \\
10.1 \\
<4.7 \\
2.0 \\
<2.9 \\
<2.7 \\
<1.9 \\
<2.1 \\
1.0 \\
0.7\end{array}$ & $\begin{array}{r}2.7 E-16 \\
2.1 E-15 \\
1.7 E-15 \\
<1.0 E-15 \\
3.5 E-16 \\
<5.1 E-16 \\
<6.3 E-16 \\
<4.3 E-16 \\
<3.5 E-16 \\
9.2 E-17 \\
1.5 E-16\end{array}$ & $\begin{array}{r}1.1 \\
11.6 \\
7.1 \\
1.2 \\
1.1 \\
1.8 \\
1.5 \\
1.2 \\
0.6 \\
1.0 \\
0.5\end{array}$ & $\begin{array}{l}1.8 E-16 \\
1.9 E-15 \\
1.2 E-15 \\
2.6 E-16 \\
1.9 E-16 \\
3.2 E-16 \\
3.5 E-16 \\
2.7 E-16 \\
1.0 E-16 \\
9.2 E-17 \\
1.0 E-16\end{array}$ & $\begin{array}{l}9.5 E-09 \\
9.8 E-08 \\
6.0 E-08 \\
1.4 E-08 \\
9.9 E-09 \\
1.6 E-08 \\
1.8 E-08 \\
1.4 E-08 \\
5.2 E-09 \\
4.8 E-09 \\
5.4 E-09\end{array}$ & $\begin{array}{l}1.2 \\
5.2 \\
7.4 \\
1.8 \\
2.3 \\
3.1 \\
1.8 \\
2.2 \\
1.1 \\
1.3 \\
0.9\end{array}$ & $\begin{array}{l}2.0 E-04 \\
8.5 E-04 \\
1.2 E-03 \\
3.9 E-04 \\
4.0 E-04 \\
5.4 E-04 \\
4.2 E-04 \\
4.9 E-04 \\
1.8 E-04 \\
1.2 E-04 \\
2.0 E-04\end{array}$ & $\begin{array}{l}1.3 E-16 \\
5.7 E-16 \\
8.1 E-16 \\
2.6 E-16 \\
2.7 E-16 \\
3.6 E-16 \\
2.8 E-16 \\
3.3 E-16 \\
1.2 E-16 \\
8.0 E-17 \\
1.3 E-16\end{array}$ \\
\hline
\end{tabular}

$a_{A}$ "<" indicates that the maximum concentration was below detection limits (number shown is detection limit).

bpicocuries per filter.

CMicrograms per filter. 
Table A-7. Analytical Air Sample Results for Station AIR-G-3 during 1992a

\begin{tabular}{|c|c|c|c|c|c|c|c|c|c|c|c|c|c|}
\hline \multirow{2}{*}{$\begin{array}{l}\text { Sample } \\
\text { Location }\end{array}$} & \multirow{2}{*}{$\begin{array}{l}\text { Sample } \\
\text { Date }\end{array}$} & \multirow{2}{*}{$\begin{array}{l}\text { Ticket } \\
\text { Number }\end{array}$} & \multirow{2}{*}{$\begin{array}{l}\text { Filter } \\
\text { Number }\end{array}$} & \multirow{2}{*}{$\begin{array}{l}\text { Flow } \\
\text { Rate } \\
\text { (scfin) }\end{array}$} & \multirow{2}{*}{$\begin{array}{l}\text { Sample } \\
\text { Time } \\
\text { (hours) }\end{array}$} & \multicolumn{2}{|c|}{ Radiun-226 } & \multicolumn{3}{|c|}{ Thorium-230 } & \multicolumn{3}{|c|}{ Uranim } \\
\hline & & & & & & $(p C i / f)^{b}$ & $b(\mu \mathrm{Ci} / \mathrm{al})$ & $\overline{(p C i / f)}$ & $(\mu \mathrm{Ci} / \omega)$ & $(\mathrm{pg} / \mathrm{m} / \mathrm{l})$ & $(\mu g / F)^{c}$ & $\left(\mu g / m^{3}\right)$ & $\left(\mu^{C i / L L}\right)$ \\
\hline $\begin{array}{l}\text { AIR-G-3 } \\
\text { AIR-G-3 } \\
\text { AIR-G-3 } \\
\text { AIR-G-3 } \\
\text { AIR-G-3 } \\
\text { AIR-G-3 } \\
\text { AIR-G-3 } \\
\text { AIR-G-3 } \\
\text { AIR-G-3 } \\
\text { AIR-G-3 } \\
\text { AIR-G-3 } \\
\text { AIR-G-3 }\end{array}$ & $\begin{array}{l}01 / 31 / 1992 \\
02 / 29 / 1992 \\
03 / 12 / 1992 \\
04 / 17 / 1992 \\
05 / 29 / 1992 \\
06 / 26 / 1992 \\
07 / 08 / 1992 \\
08 / 21 / 1992 \\
09 / 25 / 1992 \\
10 / 30 / 1992 \\
11 / 09 / 1992 \\
12 / 28 / 1992\end{array}$ & $\begin{array}{c}\text { MLY } Y-675 \\
\text { MLY-915 } \\
\text { MLY-924 } \\
\text { MLY-770 } \\
\text { MLY-869 } \\
\text { MLY-709 } \\
\text { MLY-718 } \\
\text { MLY-890 } \\
09221992-03 \\
10261992-03 \\
11091992-03 \\
12281992-03\end{array}$ & $\begin{array}{l}5916044 \\
5916025 \\
5916016 \\
5918854 \\
5918830 \\
5918815 \\
5916385 \\
5916341 \\
5916297 \\
5916258 \\
5916249 \\
5916204\end{array}$ & $\begin{array}{l}37 \\
36.6 \\
36 \\
35 \\
34.5 \\
33.7 \\
33.6 \\
33.8 \\
34 \\
35 \\
36 \\
37\end{array}$ & $\begin{array}{r}95.91 \\
99.00 \\
99.40 \\
56.28 \\
78.12 \\
101.14 \\
123.59 \\
74.80 \\
75.04 \\
100.71 \\
103.00 \\
77.00\end{array}$ & $\begin{array}{r}<1.2 \\
<1.2 \\
2.5 \\
<2.9 \\
<1.6 \\
3.7 \\
<2.5 \\
<2.0 \\
<1.3 \\
<2.5 \\
<0.6 \\
0.9\end{array}$ & $\begin{array}{r}<2.0 E-16 \\
<1.9 E-16 \\
4.1 E-16 \\
<8.7 E-16 \\
<3.5 E-16 \\
6.4 E-16 \\
<3.5 E-16 \\
<4.7 E-16 \\
<3.0 E-16 \\
<4.2 E-16 \\
<9.5 E-17 \\
1.9 E-16\end{array}$ & $\begin{array}{r}0.8 \\
<0.5 \\
0.5 \\
<0.5 \\
0.8 \\
0.8 \\
0.5 \\
0.7 \\
1.5 \\
0.5 \\
0.4 \\
0.3\end{array}$ & $\begin{array}{r}1.3 \mathrm{E}-16 \\
<8.1 \mathrm{E}-17 \\
8.2 \mathrm{E}-17 \\
<1.5 \mathrm{E}-16 \\
1.7 \mathrm{E}-16 \\
1.4 \mathrm{E}-16 \\
7.1 \mathrm{E}-17 \\
1.6 \mathrm{E}-16 \\
4.4 \mathrm{E}-16 \\
8.3 \mathrm{E}-17 \\
7.5 \mathrm{E}-17 \\
7.2 \mathrm{E}-17\end{array}$ & $\begin{array}{r}6.8 \mathrm{E}-09 \\
<4.2 \mathrm{E}-09 \\
4.2 \mathrm{E}-09 \\
<7.7 \mathrm{E}-09 \\
9.0 \mathrm{E}-09 \\
7.1 \mathrm{E}-09 \\
3.7 \mathrm{E}-09 \\
8.4 \mathrm{E}-09 \\
2.3 \mathrm{E}-08 \\
4.3 \mathrm{E}-09 \\
3.8 \mathrm{E}-09 \\
3.7 \mathrm{E}-09\end{array}$ & $\begin{array}{l}1.2 \\
1.2 \\
1.2 \\
1.2 \\
1.2 \\
1.8 \\
2.0 \\
1.3 \\
1.7 \\
1.2 \\
1.1 \\
0.9\end{array}$ & $\begin{array}{l}2.0 \mathrm{E}-04 \\
1.9 \mathrm{E}-04 \\
2.0 \mathrm{E}-04 \\
3.6 \mathrm{E}-04 \\
2.6 \mathrm{E}-04 \\
3.1 \mathrm{E}-04 \\
2.8 \mathrm{E}-04 \\
3.0 \mathrm{E}-04 \\
3.9 \mathrm{E}-04 \\
2.0 \mathrm{E}-04 \\
1.7 \mathrm{E}-04 \\
1.9 \mathrm{E}-04\end{array}$ & $\begin{array}{l}1.3 E-16 \\
1.3 E-16 \\
1.3 E-16 \\
2.4 E-16 \\
1.7 E-16 \\
2.1 E-16 \\
1.9 E-16 \\
2.0 E-16 \\
2.6 E-16 \\
1.3 E-16 \\
1.2 E-16 \\
1.2 E-16\end{array}$ \\
\hline
\end{tabular}

$a_{A}$ " $<$ " indicates that the maximum concentration was below detection limits (number shown is detection limit).

bpicocuries per filter.

CMicrograms per filter. 
Table A-8. Suspended Particulates (PM10) Data for Station AIR-G-1 during 1992

\begin{tabular}{|c|c|c|c|c|c|c|c|}
\hline $\begin{array}{l}\text { Sample } \\
\text { Location }\end{array}$ & $\begin{array}{c}\text { Sample } \\
\text { Date }\end{array}$ & $\begin{array}{l}\text { Ticket } \\
\text { Number }\end{array}$ & $\begin{array}{l}\text { Filter } \\
\text { Number }\end{array}$ & $\begin{array}{c}\text { Flow } \\
\text { Rate } \\
\text { (scfm) }\end{array}$ & $\begin{array}{l}\text { Sample } \\
\text { Time } \\
\text { (hours) }\end{array}$ & $\begin{array}{l}\text { Weight } \\
(g / F)^{a}\end{array}$ & $\begin{array}{l}\text { Conc. } \\
\left(\mu \mathrm{g} / \mathrm{m}^{3}\right)\end{array}$ \\
\hline
\end{tabular}

\begin{tabular}{|c|c|c|c|c|c|c|c|}
\hline $\begin{array}{l}\text { AIR-G-1 } \\
\text { AIR-G-1 } \\
\text { AIR-G-1 } \\
\text { AIR-G-1 } \\
\text { AIR-G-1 } \\
\text { AIR-G-1 } \\
\text { AIR-G-1 } \\
\text { AIR-G-1 } \\
\text { AIR-G-1 } \\
\text { AIR-G-1 } \\
\text { AIR-G-1 } \\
\text { AIR-G-1 } \\
\text { AIR-G-1 } \\
\text { AIR-G-1 } \\
\text { AIR-G-1 } \\
\text { AIR-G-1 } \\
\text { AIR-G-1 } \\
\text { AIR-G-1 } \\
\text { AIR-G-1 } \\
\text { AIR-G-1 } \\
\text { AIR-G-1 } \\
\text { AIR-G-1 } \\
\text { AIR-G-1 } \\
\text { AIR-G-1 } \\
\text { AIR-G-1 } \\
\text { AIR-G-1 } \\
\text { AIR-G-1 } \\
\text { AIR-G-1 } \\
\text { AIR-G-1 } \\
\text { AIR-G-1 } \\
\text { AIR-G-1 } \\
\text { AIR-G-1 } \\
\text { AIR-G-1 } \\
\text { AIR-G-1 } \\
\text { AIR-G-1 } \\
\text { AIR-G-1 } \\
\text { AIR-G-1 } \\
\text { AIR-G-1 } \\
\text { AIR-G-1 } \\
\text { AIR-G-1 } \\
\text { AIR-G-1 } \\
\text { AIR-G-1 } \\
\text { AIR-G-1 } \\
\text { AIR-G-1 } \\
\text { AIR-G-1 }\end{array}$ & $\begin{array}{l}01 / 03 / 1992 \\
01 / 09 / 1992 \\
01 / 15 / 1992 \\
01 / 21 / 1992 \\
01 / 26 / 1992 \\
02 / 01 / 1992 \\
02 / 06 / 1992 \\
02 / 12 / 1992 \\
02 / 18 / 1992 \\
02 / 24 / 1992 \\
03 / 03 / 1992 \\
03 / 07 / 1992 \\
03 / 13 / 1992 \\
03 / 19 / 1992 \\
03 / 25 / 1992 \\
03 / 31 / 1992 \\
04 / 06 / 1992 \\
04 / 12 / 1992 \\
04 / 18 / 1992 \\
04 / 24 / 1992 \\
04 / 30 / 1992 \\
05 / 06 / 1992 \\
05 / 12 / 1992 \\
05 / 18 / 1992 \\
05 / 24 / 1992 \\
05 / 30 / 1992 \\
06 / 05 / 1992 \\
06 / 11 / 1992 \\
06 / 17 / 1992 \\
06 / 29 / 1992 \\
07 / 05 / 1992 \\
07 / 11 / 1992 \\
07 / 17 / 1992 \\
07 / 23 / 1992 \\
07 / 29 / 1992 \\
08 / 04 / 1992 \\
08 / 10 / 1992 \\
08 / 16 / 1992 \\
08 / 22 / 1992 \\
08 / 28 / 1992 \\
09 / 03 / 1992 \\
09 / 09 / 1992 \\
09 / 15 / 1992 \\
09 / 21 / 1992 \\
09 / 27 / 1992\end{array}$ & $\begin{array}{l}\text { MLY-658 } \\
M L Y-661 \\
M L Y-664 \\
M L Y-667 \\
M L Y-670 \\
M L Y-620 \\
M L Y-901 \\
M L Y-904 \\
M L Y-907 \\
M L Y-910 \\
M L Y-916 \\
M L Y-919 \\
M L Y-925 \\
M L Y-753 \\
M L Y-756 \\
M L Y-759 \\
M L Y-762 \\
M L Y-765 \\
M L Y-771 \\
M L Y-774 \\
M I \\
Y \\
M . \\
M L Y-00 L \\
M L Y-864 \\
M L Y-870 \\
M L Y-873 \\
M L Y-701 \\
M L Y-704 \\
M L Y-710 \\
M L Y-713 \\
M L Y-719 \\
M L Y-721 \\
M L Y-723 \\
M L Y-725 \\
M L Y-878 \\
M L Y-881 \\
M L Y-884 \\
M L Y-891 \\
M L Y-894 \\
M L Y-897 \\
09091992-01 \\
09151992-01 \\
09211992-01 \\
09271992-01\end{array}$ & $\begin{array}{l}5916061 \\
5916059 \\
5916055 \\
5916052 \\
5916049 \\
5916042 \\
5916039 \\
5906036 \\
5916033 \\
5916030 \\
5916024 \\
5916021 \\
5916015 \\
5916012 \\
5916009 \\
5916006 \\
5916003 \\
5918859 \\
5918853 \\
5918850 \\
5918847 \\
5918844 \\
5918841 \\
5918838 \\
5918835 \\
5918829 \\
5918826 \\
5918823 \\
5918820 \\
5916393 \\
5916390 \\
5916384 \\
5916381 \\
5916379 \\
5916377 \\
5916353 \\
5916350 \\
5916347 \\
5916340 \\
5916337 \\
5916334 \\
5916307 \\
5916304 \\
5916301 \\
5916296\end{array}$ & $\begin{array}{l}37 \\
37 \\
37 \\
37 \\
37 \\
37 \\
36.6 \\
36.6 \\
36.6 \\
36.6 \\
36.6 \\
36 \\
36 \\
36 \\
36 \\
35 \\
35 \\
35 \\
35 \\
35 \\
35 \\
35 \\
35 \\
34.5 \\
34.5 \\
34.5 \\
33.7 \\
33.7 \\
33.7 \\
33.7 \\
33.6 \\
33.6 \\
33.6 \\
33.6 \\
33.6 \\
33.6 \\
33.8 \\
33.8 \\
33.8 \\
33.8 \\
34 \\
34 \\
34 \\
34 \\
34\end{array}$ & $\begin{array}{l}24.31 \\
24.30 \\
24.31 \\
24.32 \\
24.31 \\
24.01 \\
24.02 \\
23.96 \\
23.97 \\
23.88 \\
24.05 \\
24.06 \\
23.94 \\
23.94 \\
23.98 \\
23.96 \\
23.95 \\
23.96 \\
24.42 \\
24.43 \\
24.41 \\
24.44 \\
24.48 \\
24.44 \\
24.42 \\
24.28 \\
24.28 \\
24.32 \\
24.28 \\
23.74 \\
23.69 \\
23.98 \\
23.92 \\
23.93 \\
23.93 \\
23.94 \\
23.91 \\
23.91 \\
24.23 \\
24.24 \\
24.34 \\
24.25 \\
24.24 \\
24.25 \\
23.77\end{array}$ & $\begin{array}{l}0.0287 \\
0.0164 \\
0.0272 \\
0.0640 \\
0.0689 \\
0.0560 \\
0.0171 \\
0.0147 \\
0.0211 \\
0.0146 \\
0.0213 \\
0.0095 \\
0.0280 \\
0.0216 \\
0.0122 \\
0.0148 \\
0.0218 \\
0.0255 \\
0.0046 \\
0.0203 \\
0.0403 \\
0.0382 \\
0.0188 \\
0.0242 \\
0.0057 \\
0.0082 \\
0.0162 \\
0.0183 \\
0.0282 \\
0.0267 \\
0.0275 \\
0.0179 \\
0.0307 \\
0.0157 \\
0.0303 \\
0.0266 \\
0.0309 \\
0.0211 \\
0.0099 \\
0.0309 \\
0.0218 \\
0.0214 \\
0.0128 \\
0.0201 \\
0.0352\end{array}$ & $\begin{array}{r}19 \\
11 \\
18 \\
42 \\
45 \\
37 \\
11 \\
10 \\
14 \\
10 \\
14 \\
6 \\
19 \\
15 \\
8 \\
10 \\
15 \\
18 \\
3 \\
14 \\
28 \\
26 \\
13 \\
17 \\
4 \\
6 \\
12 \\
13 \\
20 \\
20 \\
20 \\
13 \\
22 \\
11 \\
22 \\
19 \\
23 \\
15 \\
7 \\
22 \\
16 \\
15 \\
9 \\
14 \\
26\end{array}$ \\
\hline
\end{tabular}

aGrams per filter. 
Table A-8 (continued). Suspended Particulates (PM10) Data for Station AIR-G-1 during 1992

\begin{tabular}{lccccccr}
\hline $\begin{array}{c}\text { Sample } \\
\text { Location }\end{array}$ & $\begin{array}{c}\text { Sample } \\
\text { Date }\end{array}$ & $\begin{array}{c}\text { Ticket } \\
\text { Number }\end{array}$ & $\begin{array}{c}\text { Filter } \\
\text { Number }\end{array}$ & $\begin{array}{c}\text { Flow } \\
\text { Rate } \\
\text { (scfm) }\end{array}$ & $\begin{array}{c}\text { Sample } \\
\text { Time } \\
\text { (hours) }\end{array}$ & $\begin{array}{c}\text { Weight } \\
(\mathbf{g} / \mathbf{F})^{\mathrm{a}}\end{array}$ & $\begin{array}{c}\text { Conc. } \\
\left(\boldsymbol{\mu g} / \mathbf{m}^{3}\right)\end{array}$ \\
\hline AIR-G-1 & $10 / 03 / 1992$ & $10031992-01$ & 5916293 & 35 & 23.82 & 0.0270 & 19 \\
AIR-G-1 & $10 / 09 / 1992$ & $10091992-01$ & 5916290 & 35 & 23.76 & 0.0569 & 40 \\
AIR-G-1 & $10 / 15 / 1992$ & $10151992-01$ & 5916287 & 35 & 23.77 & 0.0367 & 26 \\
AIR-G-1 & $10 / 21 / 1992$ & $10211992-01$ & 5916263 & 35 & 23.77 & 0.0347 & 25 \\
AIR-G-1 & $11 / 02 / 1992$ & $11021992-01$ & 5916257 & 35 & 24.13 & 0.0067 & 5 \\
AIR-G-1 & $11 / 08 / 1992$ & $11081992-01$ & 5916254 & 36 & 24.19 & 0.0192 & 13 \\
AIR-G-1 & $11 / 26 / 1992$ & $11261992-01$ & 5916245 & 36 & 24.28 & 0.0069 & 5 \\
AIR-G-1 & $12 / 02 / 1992$ & $12021992-01$ & 5916221 & 36 & 24.27 & 0.0463 & 31 \\
AIR-G-1 & $12 / 08 / 1992$ & $12081992-01$ & 5916218 & 37 & 24.32 & 0.0485 & 32 \\
AIR-G-1 & $12 / 15 / 1992$ & $12151992-01$ & 5916215 & 37 & 24.27 & 0.0256 & 17 \\
AIR-G-1 & $12 / 15 / 1992$ & $12151992-01$ & 5916215 & 37 & 24.27 & 0.0256 & 17 \\
AIR-G-1 & $12 / 26 / 1992$ & $12261992-01$ & 5916209 & 37 & 24.27 & 0.0643 & 42 \\
\hline
\end{tabular}

aGrams per filter. 
Table A-9. Suspended Particulates (PM10) Data for Station AIR-G-2 during 1992

\begin{tabular}{|c|c|c|c|c|c|c|c|}
\hline $\begin{array}{l}\text { Sample } \\
\text { Location }\end{array}$ & $\begin{array}{c}\text { Sample } \\
\text { Date }\end{array}$ & $\begin{array}{l}\text { Ticket } \\
\text { Number }\end{array}$ & $\begin{array}{l}\text { Filter } \\
\text { Number }\end{array}$ & $\begin{array}{c}\text { Flow } \\
\text { Rate } \\
\text { (scfm) }\end{array}$ & $\begin{array}{l}\text { Sample } \\
\text { Time } \\
\text { (hours) }\end{array}$ & $\begin{array}{l}\text { Weight } \\
(g / F)^{a}\end{array}$ & $\begin{array}{l}\text { Conc. } \\
\left(\mu g / m^{3}\right)\end{array}$ \\
\hline
\end{tabular}

\begin{tabular}{|c|c|c|c|c|c|c|c|}
\hline $\begin{array}{l}\text { AIR-G-2 } \\
\text { AIR-G-2 } \\
\text { AIR-G-2 } \\
\text { AIR-G-2 } \\
\text { AIR-G-2 } \\
\text { AIR-G-2 } \\
\text { AIR-G-2 } \\
\text { AIR-G-2 } \\
\text { AIR-G-2 } \\
\text { AIR-G-2 } \\
\text { AIR-G-2 } \\
\text { AIR-G-2 } \\
\text { AIR-G-2 } \\
\text { AIR-G-2 } \\
\text { AIR-G-2 } \\
\text { AIR-G-2 } \\
\text { AIR-G-2 } \\
\text { AIR-G-2 } \\
\text { AIR-G-2 } \\
\text { AIR-G-2 } \\
\text { AIR-G-2 } \\
\text { AIR-G-2 } \\
\text { AIR-G-2 } \\
\text { AIR-G-2 } \\
\text { AIR-G-2 } \\
\text { AIR-G-2 } \\
\text { AIR-G-2 } \\
\text { AIR-G-2 } \\
\text { AIR-G-2 } \\
\text { AIR-G-2 } \\
\text { AIR-G-2 } \\
\text { AIR-G-2 } \\
\text { AIR-G-2 } \\
\text { AIR-G-2 } \\
\text { AIR-G-2 } \\
\text { AIR-G-2 } \\
\text { AIR-G-2 } \\
\text { AIR-G-2 } \\
\text { AIR-G-2 } \\
\text { AIR-G-2 } \\
\text { AIR-G-2 } \\
\text { AIR-G-2 } \\
\text { AIR-G-2 } \\
\text { AIR-G-2 } \\
\text { AIR-G-2 } \\
\text { AIR-G-2 } \\
\text { AIR-G-2 } \\
\end{array}$ & $\begin{array}{l}01 / 03 / 1992 \\
01 / 09 / 1992 \\
01 / 15 / 1992 \\
01 / 21 / 1992 \\
01 / 26 / 1992 \\
02 / 01 / 1992 \\
02 / 06 / 1992 \\
02 / 12 / 1992 \\
02 / 18 / 1992 \\
02 / 24 / 1992 \\
03 / 03 / 1992 \\
03 / 07 / 1992 \\
03 / 13 / 1992 \\
03 / 19 / 1992 \\
03 / 25 / 1992 \\
03 / 31 / 1992 \\
04 / 06 / 1992 \\
04 / 12 / 1992 \\
04 / 24 / 1992 \\
04 / 30 / 1992 \\
05 / 06 / 1992 \\
05 / 30 / 1992 \\
06 / 05 / 1992 \\
06 / 11 / 1992 \\
06 / 17 / 1992 \\
06 / 29 / 1992 \\
07 / 05 / 1992 \\
07 / 29 / 1992 \\
08 / 16 / 1992 \\
08 / 22 / 1992 \\
08 / 28 / 1992 \\
09 / 03 / 1992 \\
09 / 09 / 1992 \\
09 / 15 / 1992 \\
09 / 21 / 1992 \\
09 / 27 / 1992 \\
10 / 03 / 1992 \\
10 / 09 / 1992 \\
10 / 15 / 1992 \\
10 / 21 / 1992 \\
11 / 02 / 1992 \\
11 / 08 / 1992 \\
11 / 20 / 1992 \\
11 / 26 / 1992 \\
12 / 02 / 1992 \\
12 / 15 / 1992 \\
12 / 26 / 1992 \\
5001+11+01\end{array}$ & 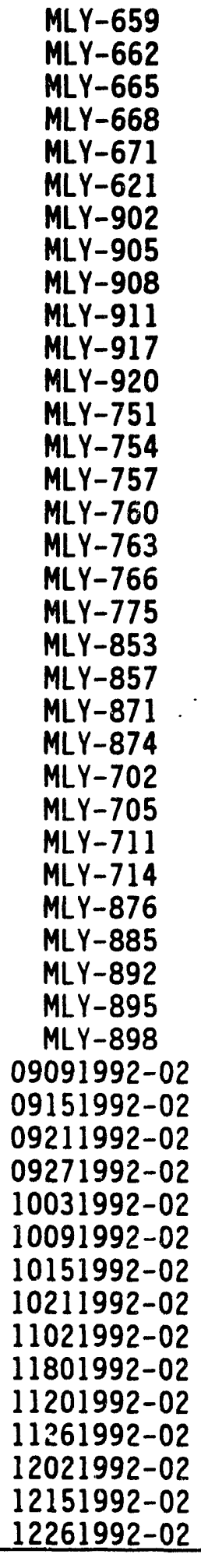 & $\begin{array}{l}5916060 \\
59160 \\
59160 \\
5916051 \\
5916048 \\
5916041 \\
5916038 \\
5916035 \\
5916032 \\
5916029 \\
5916023 \\
5916020 \\
5916014 \\
5916011 \\
5916008 \\
5916005 \\
5916002 \\
5918858 \\
5918849 \\
5918846 \\
5918843 \\
5918828 \\
5918825 \\
5918822 \\
5918819 \\
5916392 \\
5916389 \\
5916376 \\
5916346 \\
5916339 \\
5916336 \\
5916333 \\
5916306 \\
5916303 \\
5916300 \\
5916295 \\
5916292 \\
5916289 \\
5916286 \\
5916263 \\
5916256 \\
5916253 \\
5916246 \\
5916244 \\
5916220 \\
5916214 \\
5916208 \\
\end{array}$ & $\begin{array}{l}37 \\
37 \\
37 \\
37 \\
37 \\
37 \\
36.6 \\
36.6 \\
36.6 \\
36.6 \\
36.6 \\
36 \\
36 \\
36 \\
36 \\
35 \\
35 \\
35 \\
35 \\
35 \\
35 \\
34.5 \\
33.7 \\
33.7 \\
33.7 \\
33.7 \\
33.6 \\
33.6 \\
33.8 \\
33.8 \\
33.8 \\
34 \\
34 \\
34 \\
34 \\
34 \\
37 \\
35 \\
37 \\
35 \\
35 \\
35 \\
35 \\
35 \\
35 \\
36 \\
\\
36\end{array}$ & $\begin{array}{l}23.90 \\
23.88 \\
23.89 \\
23.90 \\
23.90 \\
23.71 \\
23.76 \\
23.66 \\
23.67 \\
23.66 \\
24.54 \\
23.79 \\
23.52 \\
23.52 \\
23.53 \\
23.55 \\
23.51 \\
23.50 \\
23.25 \\
23.15 \\
23.26 \\
23.93 \\
23.89 \\
23.89 \\
23.72 \\
23.56 \\
23.57 \\
24.12 \\
24.06 \\
23.43 \\
23.64 \\
23.61 \\
23.59 \\
23.58 \\
23.59 \\
23.36 \\
24.46 \\
23.43 \\
23.46 \\
23.45 \\
23.48 \\
23.54 \\
23.84 \\
23.87 \\
23.85 \\
23.87 \\
23.80 \\
\end{array}$ & $\begin{array}{l}0.0296 \\
0.0224 \\
0.0287 \\
0.0733 \\
0.0700 \\
0.0539 \\
0.0201 \\
0.0194 \\
0.0297 \\
0.0193 \\
0.0215 \\
0.0083 \\
0.0247 \\
0.0242 \\
0.0194 \\
0.0122 \\
0.0187 \\
0.0212 \\
0.0193 \\
0.0408 \\
0.0322 \\
0.0052 \\
0.0238 \\
0.0155 \\
0.0157 \\
0.0212 \\
0.0192 \\
0.0290 \\
0.0197 \\
0.0076 \\
0.0227 \\
0.0192 \\
0.0231 \\
0.0190 \\
0.0181 \\
0.0267 \\
0.0282 \\
0.0465 \\
0.0400 \\
0.0335 \\
0.0062 \\
0.0134 \\
0.0034 \\
0.0071 \\
0.0453 \\
0.0223 \\
0.0679\end{array}$ & $\begin{array}{r}20 \\
15 \\
19 \\
49 \\
47 \\
36 \\
14 \\
13 \\
20 \\
13 \\
14 \\
6 \\
17 \\
17 \\
13 \\
9 \\
13 \\
15 \\
14 \\
30 \\
23 \\
4 \\
17 \\
11 \\
12 \\
16 \\
14 \\
21 \\
14 \\
6 \\
17 \\
14 \\
17 \\
14 \\
13 \\
20 \\
19 \\
33 \\
29 \\
24 \\
4 \\
13 \\
2 \\
5 \\
31 \\
15 \\
45 \\
\end{array}$ \\
\hline
\end{tabular}


Table A-10. Suspended Particulates (PM10) Data for Station AIR-G-3 during 1992

\begin{tabular}{|c|c|c|c|c|c|c|c|}
\hline $\begin{array}{l}\text { Sample } \\
\text { Location }\end{array}$ & $\begin{array}{c}\text { Sample } \\
\text { Date }\end{array}$ & $\begin{array}{l}\text { Ticket } \\
\text { Number }\end{array}$ & $\begin{array}{l}\text { Filter } \\
\text { Number }\end{array}$ & $\begin{array}{l}\text { Flow } \\
\text { Rate } \\
\text { (scfm) }\end{array}$ & $\begin{array}{l}\text { Sample } \\
\text { Time } \\
\text { (hours) }\end{array}$ & $\begin{array}{l}\text { Weight } \\
(g / F)^{a}\end{array}$ & $\begin{array}{l}\text { Conc } \\
\left(\mu \mathrm{g} / \mathrm{m}^{3}\right)\end{array}$ \\
\hline
\end{tabular}

\begin{tabular}{|c|c|c|c|c|c|c|}
\hline $\begin{array}{l}\text { AIR-G-3 } \\
\text { AIR-G-3 } \\
\text { AIR-G-3 } \\
\text { AIR-G-3 } \\
\text { AIR-G-3 } \\
\text { AIR-G-3 } \\
\text { AIR-G-3 } \\
\text { AIR-G-3 } \\
\text { AIR-G-3 } \\
\text { AIR-G-3 } \\
\text { AIR-G-3 } \\
\text { AIR-G-3 } \\
\text { AIR-G-3 } \\
\text { AIR-G-3 } \\
\text { AIR-G-3 } \\
\text { AIR-G-3 } \\
\text { AIR-G-3 } \\
\text { AIR-G-3 } \\
\text { AIR-G-3 } \\
\text { AIR-G-3 } \\
\text { AIR-G-3 } \\
\text { AIR-G-3 } \\
\text { AIR-G-3 } \\
\text { AIR-G-3 } \\
\text { AIR-G-3 } \\
\text { AIR-G-3 } \\
\text { AIR-G-3 } \\
\text { AIR-G-3 } \\
\text { AIR-G-3 } \\
\text { AIR-G-3 } \\
\text { AIR-G-3 } \\
\text { AIR-G-3 } \\
\text { AIR-G-3 } \\
\text { AIR-G-3 } \\
\text { AIR-G-3 } \\
\text { AIR-G-3 } \\
\text { AIR-G-3 } \\
\text { AIR-G-3 } \\
\text { AIR-G-3 } \\
\text { AIR-G-3 } \\
\text { AIR-G-3 }\end{array}$ & $\begin{array}{l}01 / 03 / 1992 \\
01 / 09 / 1992 \\
01 / 15 / 1992 \\
01 / 21 / 1992 \\
02 / 01 / 1992 \\
02 / 06 / 1992 \\
02 / 12 / 1992 \\
02 / 18 / 1992 \\
02 / 24 / 1992 \\
03 / 03 / 1992 \\
03 / 07 / 1992 \\
03 / 13 / 1992 \\
03 / 19 / 1992 \\
03 / 25 / 1992 \\
03 / 31 / 1992 \\
04 / 06 / 1992 \\
04 / 12 / 1992 \\
04 / 18 / 1992 \\
04 / 24 / 1992 \\
04 / 30 / 1992 \\
05 / 06 / 1992 \\
05 / 12 / 1992 \\
05 / 18 / 1992 \\
05 / 24 / 1992 \\
05 / 30 / 1992 \\
06 / 05 / 1992 \\
06 / 11 / 1992 \\
06 / 17 / 1992 \\
06 / 29 / 1992 \\
07 / 05 / 1992 \\
07 / 17 / 1992 \\
07 / 23 / 1992 \\
07 / 29 / 1992 \\
08 / 04 / 1992 \\
08 / 10 / 1992 \\
08 / 16 / 1992 \\
08 / 22 / 1992 \\
08 / 28 / 1992 \\
09 / 03 / 1992 \\
09 / 21 / 1992 \\
09 / 27 / 1992\end{array}$ & $\begin{array}{l}M L Y-660 \\
M L Y-663 \\
M L Y-666 \\
M L Y-669 \\
M L Y-622 \\
M L Y-903 \\
M L Y-906 \\
M L Y-909 \\
M L Y-912 \\
M L Y-918 \\
M L Y-921 \\
M L Y-752 \\
M L Y-755 \\
M L Y-758 \\
M L Y-761 \\
M L Y-764 \\
M L Y-767 \\
M L Y-773 \\
M L Y-851 \\
M L Y-854 \\
M L Y-858 \\
M L Y-861 \\
M Y L-863 \\
M L Y-866 \\
M L Y-872 \\
M L Y-875 \\
M L Y-703 \\
M L Y-706 \\
M L Y-712 \\
M L Y-715 \\
M L Y-722 \\
M L Y-724 \\
M L Y-877 \\
M L Y-880 \\
M L Y-883 \\
M L Y-885 \\
M L Y-893 \\
M L Y-896 \\
M L Y-899 \\
09211992-03 \\
09271992-03\end{array}$ & $\begin{array}{l}5916059 \\
5916056 \\
5916053 \\
5916050 \\
5916040 \\
5916037 \\
5916034 \\
5916031 \\
5916028 \\
5916022 \\
5916019 \\
5916013 \\
5916010 \\
5916007 \\
5916004 \\
5916001 \\
5918857 \\
5918851 \\
591 \\
591 \\
5918 \\
591842 \\
5918839 \\
5918833 \\
5918827 \\
5918824 \\
5918821 \\
5918818 \\
5916391 \\
5916388 \\
5916382 \\
5916378 \\
5916375 \\
5916351 \\
5916348 \\
5916345 \\
5916338 \\
5916335 \\
5916332 \\
5916302 \\
5916294\end{array}$ & $\begin{array}{l}37 \\
37 \\
37 \\
37 \\
37 \\
36.6 \\
36.6 \\
36.6 \\
36.6 \\
36.6 \\
36 \\
36 \\
36 \\
36 \\
35 \\
35 \\
35 \\
35 \\
35 \\
35 \\
35 \\
35 \\
34.5 \\
34.5 \\
34.5 \\
33.7 \\
33.7 \\
33.7 \\
33.7 \\
33.6 \\
33.6 \\
33.6 \\
33.6 \\
33.6 \\
33.8 \\
33.8 \\
33.8 \\
33.8 \\
34 \\
34 \\
34\end{array}$ & $\begin{array}{l}24.15 \\
24.12 \\
24.11 \\
24.10 \\
24.33 \\
24.30 \\
24.27 \\
24.30 \\
24.25 \\
24.11 \\
24.38 \\
24.00 \\
23.98 \\
24.00 \\
23.99 \\
23.97 \\
23.95 \\
24.39 \\
24.39 \\
24.37 \\
24.37 \\
24.41 \\
24.38 \\
24.38 \\
24.40 \\
24.40 \\
24.42 \\
24.41 \\
23.97 \\
23.97 \\
23.66 \\
23.64 \\
23.66 \\
23.68 \\
23.62 \\
23.64 \\
23.84 \\
23.89 \\
23.94 \\
23.91 \\
23.92\end{array}$ & $\begin{array}{l}0.0305 \\
0.0274 \\
0.0321 \\
0.0800 \\
0.0623 \\
0.0284 \\
0.0172 \\
0.0337 \\
0.0177 \\
0.0199 \\
0.0112 \\
0.0303 \\
0.0261 \\
0.0167 \\
0.0144 \\
0.0249 \\
0.0269 \\
0.0028 \\
0.0257 \\
0.0426 \\
0.0483 \\
0.0185 \\
0.0287 \\
0.0064 \\
0.0075 \\
0.0165 \\
0.0164 \\
0.0262 \\
0.0274 \\
0.0240 \\
0.0232 \\
0.0187 \\
0.0294 \\
0.0289 \\
0.0259 \\
0.0306 \\
0.0090 \\
0.0262 \\
0.0281 \\
0.0244 \\
0.0336\end{array}$ \\
\hline
\end{tabular}

aGrams per filter. 
Table A-10 (continued). Suspended Particulates (PM10) Data for Station AIR-G-3 during 1992

\begin{tabular}{|c|c|c|c|c|c|c|c|}
\hline $\begin{array}{l}\text { Sample } \\
\text { Location }\end{array}$ & $\begin{array}{c}\text { Sample } \\
\text { Date }\end{array}$ & $\begin{array}{l}\text { Ticket } \\
\text { Number }\end{array}$ & $\begin{array}{l}\text { Filter } \\
\text { Number }\end{array}$ & $\begin{array}{l}\text { Flow } \\
\text { Rate } \\
\text { (scfm) }\end{array}$ & $\begin{array}{l}\text { Sample } \\
\text { Time } \\
\text { (hours) }\end{array}$ & $\begin{array}{l}\text { Weight } \\
(\mathrm{g} / \mathrm{f})^{\mathrm{a}}\end{array}$ & $\underset{\left(\mu \mathrm{g} / \mathrm{m}^{3}\right)}{\text { Conc })}$ \\
\hline
\end{tabular}

\begin{tabular}{lllllllr} 
AIR-G-3 & $10 / 03 / 1992$ & $10031992-03$ & 5916291 & 35 & 23.93 & 0.0368 & 26 \\
AIR-G-3 & $10 / 09 / 1992$ & $10091992-03$ & 5916288 & 35 & 23.89 & 0.0533 & 38 \\
AIR-G-3 & $10 / 15 / 1992$ & $10151992-03$ & 5916285 & 35 & 23.46 & 0.0484 & 35 \\
AIR-G-3 & $10 / 21 / 1992$ & $10211992-03$ & 5916261 & 35 & 23.92 & 0.0466 & 33 \\
AIR-G-3 & $11 / 02 / 1992$ & $11021992-03$ & 5916255 & 35 & 24.47 & 0.0064 & 4 \\
AIR-G-3 & $11 / 08 / 1992$ & $11081992-03$ & 5916252 & 36 & 24.53 & 0.0247 & 16 \\
AIR-G-3 & $11 / 26 / 1992$ & $11261992-03$ & 5916243 & 36 & 15.17 & 0.0120 & 13 \\
AIR-G-3 & $12 / 08 / 1992$ & $12081992-03$ & 5916216 & 37 & 24.00 & 0.0456 & 30 \\
AIR-G-3 & $12 / 15 / 1992$ & $12151992-03$ & 5916213 & 37 & 24.00 & 0.0247 & 16 \\
AIR-G-3 & $12 / 20 / 1992$ & $12201992-03$ & 5916210 & 37 & 24.00 & 0.0654 & 43 \\
\hline
\end{tabular}

aGrams per filter. 
Tabie A-11. Environmental Radiation Exposure Data for Grand Junction, First Quarter 1992

$\begin{array}{cccrc}\text { Report Number } & \text { Report Date } \\ 8052-4 & 05 / 13 / 1992 & \text { Date Installed } & \text { Date Removed } & \text { Days Exposed } \\ & 12 / 31 / 1991 & 03 / 31 / 1992 & 91\end{array}$

\begin{tabular}{|c|c|c|c|c|c|}
\hline $\begin{array}{c}\text { Report } \\
\text { ID }\end{array}$ & $\begin{array}{r}\text { TLD } \\
\text { ID }\end{array}$ & $\begin{array}{l}\text { Field } \\
\text { Location }\end{array}$ & $\begin{array}{l}\text { Reported Valuea } \\
\text { for Quarter } \\
\text { (mrem) }\end{array}$ & $\begin{array}{c}\text { Corrected Valueb } \\
\text { Daily Exposure } \\
\text { (mrem) }\end{array}$ & $\begin{array}{c}\text { Approximate } \\
\text { Annual Exposure } \\
\text { (mrem) }\end{array}$ \\
\hline $\begin{array}{l}1992-1 \\
1992-1 \\
1992-1 \\
1992-1 \\
1992-1 \\
1992-1 \\
1992-1 \\
1992-1 \\
1992-1 \\
1992-1 \\
1992-1 \\
1992-1 \\
1992-1 \\
1992-1 \\
1992-1 \\
1992-1\end{array}$ & $\begin{array}{l}G J-19 \\
G J-29 \\
G J-25 \\
G J-21 \\
G J-22 \\
G J-24 \\
G J-17 \\
G J-23 \\
G J-15 \\
G J-20 \\
G J-18 \\
G J-26 \\
G J-16 \\
G J-28 \\
G J-30 \\
G J-27\end{array}$ & $\begin{array}{l}\text { TLD-G-01 } \\
\text { TLD-G-02 } \\
\text { TLD-G-03 } \\
\text { TLD-G-04 } \\
\text { TLD-G-04-DC } \\
\text { TLD-G-05 } \\
\text { TLD-G-06 } \\
\text { TLD-G-07 } \\
\text { TLD-G-08 } \\
\text { TLD-G-09 } \\
\text { TLD-G-10 } \\
\text { TLD-G-11 } \\
\text { TLD-G-12 } \\
\text { TLD-G-13 } \\
\text { TLD-G-14 } \\
\text { TLD-G-15 }\end{array}$ & $\begin{array}{l}25.5 \\
23.5 \\
25.1 \\
28.3 \\
28.5 \\
22.8 \\
22.5 \\
23.1 \\
26.7 \\
27.2 \\
20.8 \\
21.7 \\
24.5 \\
21.7 \\
20.0 \\
20.5\end{array}$ & $\begin{array}{l}0.3 \\
0.3 \\
0.3 \\
0.3 \\
0.3 \\
0.3 \\
0.2 \\
0.3 \\
0.3 \\
0.3 \\
0.2 \\
0.2 \\
0.3 \\
0.2 \\
0.2 \\
0.2\end{array}$ & $\begin{array}{r}102.3 \\
94.3 \\
100.7 \\
113.5 \\
114.3 \\
91.5 \\
90.2 \\
92.7 \\
107.1 \\
109.1 \\
83.4 \\
87.0 \\
98.3 \\
87.0 \\
80.2 \\
82.2\end{array}$ \\
\hline
\end{tabular}

aThe reported values are the results received from the subcontracted laboratory.

bThe corrected values are derived by subtracting the exposure received by the TLDs while in transit from the reported values.

cDuplicate sample 
Table A-12. Environmental Radiation Exposure Data for Grand Junction, Second Quarter 1992

\begin{tabular}{|c|c|c|c|c|c|}
\hline \multicolumn{2}{|c|}{$\begin{array}{l}\text { Report Number } \\
8052-5\end{array}$} & \multirow{2}{*}{$\begin{array}{c}\begin{array}{c}\text { Report Date } \\
08 / 04 / 1992\end{array} \\
\begin{array}{c}\text { Field } \\
\text { Location }\end{array}\end{array}$} & \multirow{2}{*}{$\begin{array}{c}\begin{array}{c}\text { Date Installed } \\
03 / 31 / 1992\end{array} \\
\begin{array}{c}\text { Reported Valuea } \\
\text { for Quarter } \\
\text { (mrem) }\end{array}\end{array}$} & \multirow{2}{*}{$\begin{array}{c}\begin{array}{c}\text { Date Removed } \\
06 / 30 / 1992\end{array} \\
\begin{array}{c}\text { Corrected Valueb } \\
\text { Daily Exposure } \\
\text { (mrem) }\end{array}\end{array}$} & \multirow{2}{*}{$\begin{array}{c}\text { Days Exposed } \\
91\end{array}$} \\
\hline $\begin{array}{c}\text { Report } \\
\text { ID }\end{array}$ & TLD & & & & \\
\hline $\begin{array}{l}1992-2 \\
1992-2 \\
1992-2 \\
1992-2 \\
1992-2 \\
1992-2 \\
1992-2 \\
1992-2 \\
1992-2 \\
1992-2 \\
1992-2 \\
1992-2 \\
1992-2 \\
1992-2 \\
1992-2 \\
1992-2\end{array}$ & $\begin{array}{l}G J-1 \\
G J-2 . \\
G J-3 \\
G J-4 \\
G J-15 \\
G J-5 \\
G J-6 \\
G J-7 \\
G J-8 \\
G J-9 \\
G J-10 \\
G J-11 \\
G J-12 \\
G J-13 \\
G J-14 \\
G J-16\end{array}$ & $\begin{array}{l}\text { TLD-G-01 } \\
\text { TLD-G-02 } \\
\text { TLD-G-03 } \\
\text { TLD-G-04 } \\
\text { TLD-G-04-DC } \\
\text { TLD-G-05 } \\
\text { TLD-G-06 } \\
\text { TLD-G-07 } \\
\text { TLD-G-08 } \\
\text { TLD-G-09 } \\
\text { TLD-G-10 } \\
\text { TLD-G-11 } \\
\text { TLD-G-12 } \\
\text { TLD-G-13 } \\
\text { TLD-G-14 } \\
\text { TLD-G-15 }\end{array}$ & $\begin{array}{l}14.7 \\
23.9 \\
26.9 \\
22.5 \\
23.7 \\
25.3 \\
26.3 \\
23.8 \\
26.1 \\
25.1 \\
21.5 \\
21.7 \\
23.7 \\
22.8 \\
23.1 \\
22.8\end{array}$ & $\begin{array}{l}0.2 \\
0.3 \\
0.3 \\
0.2 \\
0.3 \\
0.3 \\
0.3 \\
0.3 \\
0.3 \\
0.3 \\
0.2 \\
0.2 \\
0.3 \\
0.3 \\
0.3 \\
0.3\end{array}$ & $\begin{array}{r}59.0 \\
95.9 \\
107.9 \\
90.2 \\
95.1 \\
101.5 \\
105.5 \\
95.5 \\
104.7 \\
100.7 \\
86.2 \\
87.0 \\
95.1 \\
91.5 \\
92.7 \\
91.5\end{array}$ \\
\hline
\end{tabular}

aThe reported values are the results received from the subcontracted laboratory.

bThe corrected values are derived by subtracting the exposure received by the TLDs while in transit from the reported values.

cDuplicate sample. 
Table A-13. Environmental Radiation Exposure Data for Grand Junction, Third Quarter 1992

\begin{tabular}{|c|c|c|c|c|c|}
\hline \multicolumn{2}{|c|}{$\begin{array}{l}\text { Report Number } \\
8052-6\end{array}$} & \multirow{2}{*}{$\begin{array}{c}\begin{array}{c}\text { Report Date } \\
10 / 10 / 1992\end{array} \\
\begin{array}{c}\text { Field } \\
\text { Location }\end{array}\end{array}$} & \multirow{2}{*}{$\begin{array}{c}\text { Date Installed } \\
06 / 30 / 1992 \\
\begin{array}{c}\text { Reported Valuea } \\
\text { for Quarter } \\
\text { (mrem) }\end{array}\end{array}$} & \multirow{2}{*}{$\begin{array}{c}\begin{array}{c}\text { Date Removed } \\
10 / 01 / 1992\end{array} \\
\begin{array}{c}\text { Corrected Valueb } \\
\text { Daily Exposure } \\
\text { (mrem) }\end{array}\end{array}$} & \multirow{2}{*}{$\begin{array}{c}\text { Days Exposed } \\
92\end{array}$} \\
\hline $\begin{array}{l}\text { Report } \\
\text { ID }\end{array}$ & $\begin{array}{r}\text { TLD } \\
\text { ID }\end{array}$ & & & & \\
\hline $\begin{array}{l}1992-3 \\
1992-3 \\
1992-3 \\
1992-3 \\
1992-3 \\
1992-3 \\
1992-3 \\
1992-3 \\
1992-3 \\
1992-3 \\
1992-3 \\
1992-3 \\
1992-3 \\
1992-3 \\
1992-3 \\
1992-3\end{array}$ & $\begin{array}{l}G J-16 \\
G J-12 \\
G J-7 \\
G J-1 \\
G J-2 \\
G J-15 \\
G J-5 \\
G J-10 \\
G J-11 \\
G J-4 \\
G J-14 \\
G J-13 \\
G J-9 \\
G J-3 \\
G J-8 \\
G J-6\end{array}$ & $\begin{array}{l}\text { TLD-G-01 } \\
\text { TLD-G-02 } \\
\text { TLD-G-03 } \\
\text { TLD-G-04 } \\
\text { TLD-G-04-DC } \\
\text { TLD-G-05 } \\
\text { TLD-G-06 } \\
\text { TLD-G-07 } \\
\text { TLD-G-08 } \\
\text { TLD-G-09 } \\
\text { TLD-G-10 } \\
\text { TLD-G-11 } \\
\text { TLD-G-12 } \\
\text { TLD-G-13 } \\
\text { TLD-G-14 } \\
\text { TLD-G-15 }\end{array}$ & $\begin{array}{l}26.3 \\
21.7 \\
28.6 \\
34.1 \\
36.0 \\
24.0 \\
26.8 \\
22.1 \\
23.0 \\
24.5 \\
20.3 \\
22.0 \\
24.0 \\
22.3 \\
22.0 \\
22.1\end{array}$ & $\begin{array}{l}0.3 \\
0.2 \\
0.3 \\
0.4 \\
0.4 \\
0.3 \\
0.3 \\
0.2 \\
0.3 \\
0.3 \\
0.2 \\
0.2 \\
0.3 \\
0.2 \\
0.2 \\
0.2\end{array}$ & $\begin{array}{r}104.3 \\
86.1 \\
113.5 \\
135.3 \\
142.8 \\
95.2 \\
106.3 \\
87.7 \\
91.3 \\
97.2 \\
80.5 \\
87.3 \\
95.2 \\
88.5 \\
87.3 \\
87.7\end{array}$ \\
\hline
\end{tabular}

aThe reported values are the results received from the subcontracted laboratory.

bThe corrected values are derived by subtracting the exposure received by the TLDs while in transit from the reported values.

cDuplicate sample 
Table A-14. Environmental Radiation Exposure Data for Grand Junction, Fourth Quarter 1992

\begin{tabular}{|c|c|c|c|c|c|}
\hline \multicolumn{2}{|c|}{$\begin{array}{l}\text { Report Number } \\
8052-7\end{array}$} & \multirow{2}{*}{$\begin{array}{c}\begin{array}{r}\text { Report Date } \\
01 / 20 / 1993\end{array} \\
\begin{array}{c}\text { Field } \\
\text { Location }\end{array}\end{array}$} & \multirow{2}{*}{$\begin{array}{c}\begin{array}{c}\text { Date Installed } \\
10 / 01 / 1992\end{array} \\
\begin{array}{c}\text { Reported Valuea } \\
\text { for Quarter } \\
\text { (mrem) }\end{array}\end{array}$} & \multirow{2}{*}{$\begin{array}{c}\begin{array}{c}\text { Date Removed } \\
12 / 30 / 1992\end{array} \\
\begin{array}{c}\text { Corrected Valueb } \\
\text { Daily Exposure } \\
\text { (mrem) }\end{array}\end{array}$} & \multirow{2}{*}{$\begin{array}{c}\text { Days Exposed } \\
90\end{array}$} \\
\hline $\begin{array}{l}\text { Report } \\
\text { ID }\end{array}$ & TLD & & & & \\
\hline $\begin{array}{l}1992-4 \\
1992-4 \\
1992-4 \\
1992-4 \\
1992-4 \\
1992-4 \\
1992-4 \\
1992-4 \\
1992-4 \\
1992-4 \\
1992-4 \\
1992-4 \\
1992-4 \\
1992-4 \\
1992-4 \\
1992-4\end{array}$ & $\begin{array}{l}G J-20 \\
G J-32 \\
G J-27 \\
G J-15 \\
G J-30 \\
G J-22 \\
G J-29 \\
G J-28 \\
G J-31 \\
G J-17 \\
G J-23 \\
G J-24 \\
G J-18 \\
G J-21 \\
G J-26 \\
G J-34\end{array}$ & $\begin{array}{l}\text { TLD-G-01 } \\
\text { TLD-G-02 } \\
\text { TLD-G-03 } \\
\text { TLD-G-04 } \\
\text { TLD-G-04-DC } \\
\text { TLD-G-05 } \\
\text { TLD-G-06 } \\
\text { TLD-G-07 } \\
\text { TLD-G-08 } \\
\text { TLD-G-09 } \\
\text { TLD-G-10 } \\
\text { TLD-G-11 } \\
\text { TLD-G-12 } \\
\text { TLD-G-13 } \\
\text { TLD-G-14 } \\
\text { TLD-G-15 }\end{array}$ & $\begin{array}{l}27.3 \\
26.4 \\
31 . .2 \\
22.9 \\
24.6 \\
25.3 \\
26.1 \\
27.8 \\
27.0 \\
26.0 \\
22.7 \\
23.3 \\
27.7 \\
26.5 \\
23.3 \\
25.0\end{array}$ & $\begin{array}{l}0.3 \\
0.3 \\
0.3 \\
0.3 \\
0.3 \\
0.3 \\
0.3 \\
0.3 \\
0.3 \\
0.3 \\
0.3 \\
0.3 \\
0.3 \\
0.3 \\
0.3 \\
0.3\end{array}$ & $\begin{array}{r}110.7 \\
107.1 \\
126.5 \\
92.9 \\
99.8 \\
102.6 \\
105.9 \\
112.7 \\
109.5 \\
105.4 \\
92.1 \\
94.5 \\
112.3 \\
107.5 \\
94.5 \\
101.4\end{array}$ \\
\hline
\end{tabular}

aThe reported values are the results received from the subcontracted 1 aboratory.

bThe corrected values are derived by subtracting the exposure received by the TLDs while in transit from the reported values.

cDuplicate sample. 
Table A-15. Meteorological Data for Grand Junction

Frequency of Vind Directionsa

\begin{tabular}{lc}
\hline Uind Toward & Frequency \\
\hline N & 0.052 \\
NNW & 0.073 \\
NW & 0.140 \\
WNW & 0.199 \\
WSW & 0.054 \\
SW & 0.051 \\
SSW & 0.031 \\
S & 0.023 \\
SSE & 0.040 \\
SE & 0.045 \\
ESE & 0.075 \\
E & 0.098 \\
ENE & 0.042 \\
NE & 0.025 \\
NNE & 0.027 \\
\end{tabular}

Frequency of Each Stability Class for Each Direction

\begin{tabular}{|c|c|c|c|c|c|c|}
\hline \multirow[t]{2}{*}{ Wind Toward } & \multicolumn{6}{|c|}{ Fraction of Time in Each Stability Classb } \\
\hline & A & B & $c$ & D & $E$ & $\mathrm{~F}$ \\
\hline N & 0.0418 & 0.2162 & 0.2074 & 0.3218 & 0.0615 & 0.1513 \\
\hline NNW & 0.0282 & 0.1580 & 0.2393 & 0.3084 & 0.0923 & 0.1738 \\
\hline NW & 0.0087 & 0.0685 & 0.1520 & 0.3159 & 0.1921 & 0.2628 \\
\hline WNW & 0.0045 & 0.0333 & 0.0608 & 0.3729 & 0.2641 & 0.2644 \\
\hline W & 0.0085 & 0.0452 & 0.0459 & 0.1993 & 0.1790 & 0.5220 \\
\hline WSW & 0.0103 & 0.0348 & 0.0363 & 0.1736 & 0.1623 & 0.5827 \\
\hline SW & 0.0205 & 0.0668 & 0.0587 & 0.2515 & 0.1838 & 0.4187 \\
\hline SSW & 0.0141 & 0.0872 & 0.0872 & 0.2945 & 0.1805 & 0.3364 \\
\hline S & 0.0181 & 0.0915 & 0.0912 & 0.3417 & 0.1800 & 0.2774 \\
\hline SSE & 0.0128 & 0.1119 & 0.1468 & 0.4019 & 0.1477 & 0.1790 \\
\hline SE & 0.0202 & 0.1270 & 0.1914 & 0.4042 & 0.1128 & 0.1444 \\
\hline ESE & 0.0314 & 0.1662 & 0.2315 & 0.3691 & 0.0719 & 0.1298 \\
\hline$E$ & 0.0449 & 0.2164 & 0.2214 & 0.3198 & 0.0582 & 0.1392 \\
\hline ENE & 0.0852 & 0.2738 & 0.1688 & 0.2631 & 0.0654 & 0.1438 \\
\hline NE & 0.0697 & 0.2387 & 0.1531 & 0.3384 & 0.0550 & 0.1450 \\
\hline NNE & 0.0675 & 0.2300 & 0.1764 & 0.3329 & 0.0494 & 0.1439 \\
\hline
\end{tabular}

a Average atmospheric lid for the area is 538 meters.

bstability classes $A, B$, and $C$ refer to daytime, unstable conditions, with class $A$ having the most unstable conditions. Class $D$ refers to overcast or neutral conditions at night or during the day. Classes $E$ and $F$ refer to nightime, stable conditions and are based on the amount of cloud cover, with $F$ having greater or thicker cloud cover. 
Table A-15 (continued). Meteorological Data for Grand Junction

Reciprocal-Averaged Uind Speeds

Mind Toward

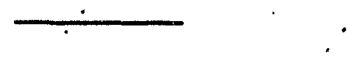

$N$
$N$ iWW
$N W$
$W N W$
$W$
$W S W$
SW
SSW
S
SSE
SE
ESE
E
ENE
NE
NNE
Wind Speed (maters/second) in Each Stability Class

\begin{tabular}{llllll}
\hline$A$ & $B$ & $C$ & $D$ & $E$ & $F$ \\
\cline { 2 - 4 } 1.03 & 1.27 & 2.19 & 3.32 & 3.11 & 0.97 \\
1.12 & 1.36 & 2.55 & 3.51 & 3.30 & 1.37 \\
1.02 & 1.40 & 2.60 & 3.94 & 3.71 & 1.29 \\
0.96 & 1.20 & 2.28 & 4.33 & 3.72 & 1.28 \\
0.93 & 1.01 & 1.28 & 2.33 & 3.12 & 1.07 \\
0.98 & 0.94 & 1.29 & 2.43 & 2.93 & 1.13 \\
0.91 & 1.00 & 1.49 & 2.62 & 3.13 & 1.03 \\
1.10 & 0.96 & 1.50 & 2.91 & 3.21 & 1.06 \\
0.99 & 1.06 & 1.65 & 3.12 & 3.27 & 1.11 \\
1.04 & 1.16 & 2.10 & 3.27 & 3.28 & 1.17 \\
1.06 & 1.31 & 2.38 & 3.34 & 3.26 & 1.12 \\
1.08 & 1.37 & 2.43 & 3.20 & 3.08 & 1.02 \\
1.11 & 1.36 & 2.29 & 2.82 & 2.96 & 0.97 \\
1.06 & 1.23 & 2.10 & 2.67 & 2.85 & 0.91 \\
1.10 & 1.17 & 2.18 & 3.24 & 2.95 & 0.94 \\
1.11 & 1.14 & 2.34 & 3.36 & 2.98 & 0.92
\end{tabular}

Average Wind Speeds

Wind Toward

N
NNW
NW
$W N W$
$W$
$W S W$
SW
SSW
S
SSE
SE
ESE
E
ENE
NE
NNE

Vind Speed (meters/second) in Each Stablity Class

\begin{tabular}{|c|c|c|c|c|c|}
\hline $\bar{A}$ & $B$ & $C$ & $D$ & $E$ & $F$ \\
\hline 1.41 & 1.99 & 3.41 & 5.52 & 3.11 & 1.29 \\
\hline 1.57 & 2.16 & 3.50 & 5.20 & 3.53 & 1.60 \\
\hline 1.41 & 2.21 & 3.59 & 5.30 & 3.92 & 1.81 \\
\hline 1.28 & 1.91 & 3.32 & 5.65 & 3.92 & 1.79 \\
\hline 1.20 & 1.44 & 2.19 & 4.12 & 3.34 & 1.49 \\
\hline 1.32 & 1.32 & 2.38 & 4.2 & 3.11 & 1.52 \\
\hline 1.17 & 1.46 & 2.59 & 4.8 & 3.55 & 1.41 \\
\hline 1.54 & 1.39 & 2.57 & 4.80 & 3.45 & 1.47 \\
\hline 1.34 & 1.58 & 2.77 & 4.68 & 3.51 & 1.56 \\
\hline 1.43 & 1.82 & 3.32 & 4.97 & 3.51 & 1.65 \\
\hline 1.47 & 2.15 & 3.60 & 5.07 & 3.50 & 1.57 \\
\hline 1.51 & 2.29 & 3.67 & 5.02 & 3.30 & 1.41 \\
\hline 1.55 & 2.26 & 3.53 & 5.15 & 3.14 & 1.31 \\
\hline 1.48 & 1.99 & 3.30 & 5.09 & 3.00 & 1.16 \\
\hline 1.53 & 1.88 & 4.04 & 5.91 & 3.13 & 1.23 \\
\hline 1.55 & 1.79 & 4.12 & 6.05 & 3.17 & 1.19 \\
\hline
\end{tabular}


Table A-16. Sewer Effluent Chemistry Data for Grand Junction during 1992a,b

\begin{tabular}{|c|c|c|c|c|c|c|c|c|c|c|c|c|}
\hline $\begin{array}{l}\text { Ticket } \\
\text { Number }\end{array}$ & $\begin{array}{l}\text { Sample } \\
\text { Date }\end{array}$ & $\underset{(\mu g / L)}{A g}$ & $\begin{array}{c}\text { Alpha } \\
(p C i / L)^{c}\end{array}$ & $\underset{(\mu \mathrm{m} / \mathrm{L})}{\text { As }}$ & $\begin{array}{c}\mathrm{Be} \\
(\mu \mathrm{g} / \mathrm{L})\end{array}$ & $\begin{array}{c}\text { Beta } \\
(\mathrm{pCi} / L)^{b}\end{array}$ & $\begin{array}{l}\text { BOD } \\
(m g / L)\end{array}$ & $\underset{(\mu g / L)}{C d}$ & $\underset{(\mu g / L)}{C N}$ & $\begin{array}{l}\operatorname{cond} \\
(\mathrm{mg} / \mathrm{L})\end{array}$ & $\underset{(\mu g / L)}{C r}$ & $\underset{(\mu / L)}{C u}$ \\
\hline 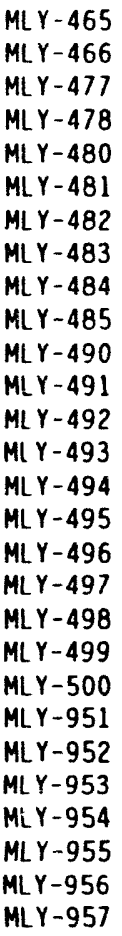 & $\begin{array}{l}01 / 09 / 1992 \\
01 / 09 / 1992 \\
02 / 13 / 1992 \\
02 / 13 / 1992 \\
02 / 24 / 1992 \\
03 / 11 / 1992 \\
03 / 11 / 1992 \\
04 / 08 / 1992 \\
04 / 08 / 1992 \\
04 / 08 / 1992 \\
05 / 07 / 1992 \\
05 / 07 / 1992 \\
05 / 07 / 1992 \\
05 / 07 / 1992 \\
05 / 14 / 1992 \\
06 / 04 / 1992 \\
06 / 04 / 1992 \\
06 / 04 / 1992 \\
06 / 04 / 1992 \\
07 / 07 / 1992 \\
07 / 07 / 1992 \\
08 / 06 / 1992 \\
08 / 06 / 1992 \\
10 / 19 / 1992 d \\
12 / 17 / 1992 \\
12 / 17 / 1992 \\
12 / 17 / 1992 \\
12 / 17 / 1992\end{array}$ & $\begin{array}{l}<5.0 \\
\text { No Data } \\
<5.0 \\
\text { No Data } \\
\text { No Data } \\
5.9 \\
\text { No Data } \\
<3.5 \\
\text { No Data } \\
\text { No Data } \\
<3.5 \\
\text { No Data } \\
\text { No Data } \\
\text { No Data } \\
<3.5 \\
<5.7 \\
<5.7 \\
\text { No Data } \\
\text { No Data } \\
\text {-9.1 } \\
\text { No Data } \\
<5.7 \\
\text { No Data } \\
<6.0 \\
38.9 \\
\text { No Data } \\
39.5 \\
\text { No Data }\end{array}$ & $\begin{array}{l}<8.8 \\
<9.3 \\
<9.1 \\
<9.3 \\
\text { No Data } \\
<11 \\
<17 \\
<5.3 \\
<5.4 \\
<7.0 \\
<4.7 \\
<4.8 \\
<9.9 \\
36.4 \\
\text { No Data } \\
<4.8 \\
<4.8 \\
39.7 \\
<4.8 \\
<12 \\
<14 \\
<7 \\
<7 \\
<30 \\
<20 \\
40 \\
<20 \\
<30\end{array}$ & $\begin{array}{l}\text { No Data } \\
\text { No Data } \\
\text { No Data } \\
\text { No Data } \\
3.5 \\
\text { No Data } \\
\text { No Data } \\
\text { No Data } \\
\text { No Data } \\
\text { No Data } \\
\text { No Data } \\
\text { No Data } \\
\text { No Data } \\
\text { No Data } \\
\text { No Data } \\
\text { No Data } \\
\text { No Data } \\
\text { No Data } \\
\text { No Data } \\
\text { No Data } \\
\text { No Data } \\
\text { No Data } \\
\text { No Data } \\
\text { No Data } \\
\text { No Data } \\
\text { No Data } \\
\text { No Data } \\
\text { No Data }\end{array}$ & $\begin{array}{l}\text { No Data } \\
\text { No Data } \\
\text { No Data } \\
\text { No Data } \\
\text { <1.0 } \\
\text { No Data } \\
\text { No Data } \\
\text { No Data } \\
\text { No Data } \\
\text { No Data } \\
\text { No Data } \\
\text { No Data } \\
\text { No Data } \\
\text { No Data } \\
\text { No Data } \\
\text { No Data } \\
\text { No Data } \\
\text { No Data } \\
\text { No Data } \\
\text { No Data } \\
\text { No Data } \\
\text { No Data } \\
\text { No Data } \\
\text { No Data } \\
\text { No Data } \\
\text { No Data } \\
\text { No Data } \\
\text { No Data }\end{array}$ & $\begin{array}{l}<10.7 \\
<13.2 \\
<9.0 \\
<9.0 \\
\text { No Data } \\
<11 \\
<22 \\
27.0 \\
26.2 \\
10.8 \\
<6.9 \\
<6.9 \\
16.1 \\
40.6 \\
\text { No Data } \\
<7.2 \\
<7.2 \\
41.6 \\
<7.2 \\
<10 \\
14 \\
<11 \\
<11 \\
<50 \\
40 \\
<40 \\
34 \\
<40\end{array}$ & $\begin{array}{l}130 \\
\text { No Data } \\
90 \\
\text { No Data } \\
\text { No Data } \\
125 \\
\text { No Data } \\
190 \\
\text { No Data } \\
\text { No Data } \\
\text { No Data } \\
\text { No Data } \\
\text { No Data } \\
\text { No Data } \\
133 \\
\text { No Data } \\
80.0 \\
\text { iro Data } \\
\text { No Data } \\
270 \\
\text { No Data } \\
35 \\
\text { No Data } \\
84 \\
3120 \\
\text { No Data } \\
\text { No Data } \\
\text { No Data }\end{array}$ & $\begin{array}{l}\text { No Data } \\
\text { No Data } \\
\text { No Data } \\
\text { No Data } \\
<4.0 \\
\text { No Data } \\
\text { No Data } \\
\text { No Data } \\
\text { No Data } \\
\text { No Data } \\
\text { No Data } \\
\text { No Data } \\
\text { No Data } \\
\text { No Data } \\
\text { No Data } \\
\text { No Data } \\
\text { No Data } \\
\text { No Data } \\
\text { No Data } \\
\text { No Data } \\
\text { No Data } \\
\text { No Data } \\
\text { No Data } \\
\text { No Data } \\
\text { No Data } \\
\text { No Data } \\
\text { No Data } \\
\text { No Data }\end{array}$ & $\begin{array}{l}<10.0 \\
\text { No Data } \\
<10.0 \\
\text { No Data } \\
\text { No Data } \\
<10.0 \\
\text { No Data } \\
<10.0 \\
\text { No Data } \\
\text { No Data } \\
<10.0 \\
\text { No Data } \\
\text { No Data } \\
\text { No Data } \\
16.5 \\
<10.0 \\
<10.0 \\
\text { No Data } \\
\text { No Data } \\
191 \\
\text { No Data } \\
<10.0 \\
\text { No Data } \\
<10.0 \\
<10.0 \\
\text { No Data } \\
<10.0 \\
\text { No Data }\end{array}$ & $\begin{array}{l}227 \\
\text { No Data } \\
112 \\
\text { No Data } \\
\text { No Data } \\
208 \\
\text { No Data } \\
327 \\
\text { No Data } \\
\text { No Data } \\
\text { No Data } \\
\text { No Data } \\
\text { No Data } \\
\text { No Data } \\
184 \\
\text { No Data } \\
125 \\
\text { No Data } \\
\text { No Data } \\
\text { 316 } \\
\text { No Data } \\
73.6 \\
\text { No Data } \\
\text { No Data } \\
\text { 3320 } \\
\text { No Data } \\
\text { No Data } \\
\text { No Data }\end{array}$ & $\begin{array}{l}<6.0 \\
\text { Ho Data } \\
<6.0 \\
\text { No Data } \\
\text { No Data } \\
4.7 \\
\text { No Data } \\
<4.0 \\
\text { No Data } \\
\text { No Data } \\
<4.0 \\
\text { No Data } \\
\text { No Data } \\
\text { No Data } \\
<4.0 \\
<3.9 \\
<3.9 \\
\text { No Data } \\
\text { No Data } \\
<3.9 \\
\text { No Data } \\
<3.9 \\
\text { No Data } \\
<6.0 \\
\text { \%9.4 } \\
\text { No Data } \\
\text { N 8.4 } \\
\text { No Data }\end{array}$ & $\begin{array}{l}30.9 \\
\text { No Data } \\
35.8 \\
\text { Mo Data } \\
\text { No Data } \\
62.7 \\
\text { No Data } \\
54.7 \\
\text { No Data } \\
\text { No Data } \\
31.6 \\
\text { No Data } \\
\text { No Data } \\
\text { No Data } \\
29.5 \\
32.4 \\
37.7 \\
\text { No Data } \\
\text { No Data } \\
98.6 \\
\text { No Data } \\
\text {-10.1 } \\
\text { No Data } \\
60.0 \\
94.7 \\
\text { No Data } \\
96.5 \\
\text { No Data }\end{array}$ \\
\hline
\end{tabular}

$a_{A}$ "<" symbol indicates that the maximum concentration was below detection limits (number shown is detection 1 imit). A " " indicates an approximate value (the value was outside the limits for which the instrument was calibrated)

bAll sewer effluent samples were collected from manhole \#12 by Geotech, with the exception of sample MLY-953, which was collected at the North Lift Station by the city of Grand Junction.

cThe values listed multiplied by $10^{-9}$ will result in $\mu \mathrm{Ci} / \mathrm{mL}$.

dChemical oxygen demand. 
Iatile A la (rontinued) Sewer iffluent Chemistry Data for Grand Junction during 1992a,b

\begin{tabular}{|c|c|c|c|c|c|c|c|c|c|c|c|}
\hline $\begin{array}{l}\text { licket } \\
\text { Number }\end{array}$ & $\begin{array}{c}\text { Sample } \\
\text { Date }\end{array}$ & $\begin{array}{c}\text { Herbicide } \\
(\mu / 1)\end{array}$ & $\begin{array}{c}\mathrm{Hg} \\
(\mu \mathrm{g} / \mathrm{I})\end{array}$ & $\begin{array}{c}N i \\
(\mu g / l)\end{array}$ & $\begin{array}{l}0 i 1 \\
(m / L)\end{array}$ & $\begin{array}{c}\mathrm{Pb} \\
(\mu g / L)\end{array}$ & $\begin{array}{c}\text { Pesticide } \\
(\mu g / L)\end{array}$ & pH & $\begin{array}{l}\text { Phenol } \\
\text { (pg/L) }\end{array}$ & $\underset{(\mu g / L)}{S b}$ & $\begin{array}{c}\text { Se } \\
(\mu g / L)\end{array}$ \\
\hline 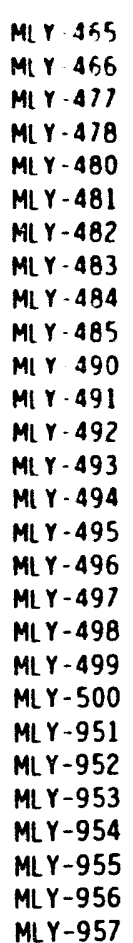 & $\begin{array}{l}01 / 09 / 1992 \\
01 / 09 / 1992 \\
02 / 13 / 1992 \\
02 / 13 / 1992 \\
02 / 24 / 1992 \\
03 / 11 / 1992 \\
03 / 11 / 1992 \\
04 / 08 / 1992 \\
04 / 08 / 1992 \\
04 / 08 / 1992 \\
05 / 07 / 1992 \\
05 / 07 / 1992 \\
05 / 07 / 1992 \\
05 / 07 / 1992 \\
05 / 14 / 1992 \\
06 / 04 / 1992 \\
06 / 04 / 1992 \\
06 / 04 / 1992 \\
06 / 04 / 1992 \\
07 / 07 / 1992 \\
07 / 07 / 1992 \\
08 / 06 / 1992 \\
08 / 06 / 1992 \\
10 / 19 / 1992 \\
12 / 17 / 1992 \\
12 / 17 / 1992 \\
12 / 17 / 1992 \\
12 / 17 / 1992\end{array}$ & $\begin{array}{l}\text { No Oata } \\
\text { No Data } \\
\text { No Data } \\
\text { No Data } \\
\text { No Detect } \\
\text { No Data } \\
\text { No Data } \\
\text { No Data } \\
\text { No Data } \\
\text { No Data } \\
\text { No Data } \\
\text { No Data } \\
\text { No Data } \\
\text { No Data } \\
\text { No Data } \\
\text { No Data } \\
\text { No Data } \\
\text { No Data } \\
\text { No Data } \\
\text { No Data } \\
\text { No Data } \\
\text { No Data } \\
\text { No Data } \\
\text { No Data } \\
\text { No Data } \\
\text { No Data } \\
\text { No Data } \\
\text { No Data }\end{array}$ & $\begin{array}{c}\text { C } 20 \\
\text { No Data } \\
\text { C. } 20 \\
\text { No Data } \\
\text { No Data } \\
<0.20 \\
\text { No Data } \\
0.13 \\
\text { No Data } \\
\text { No Data } \\
0.06 \\
\text { No Data } \\
\text { No Data } \\
\text { No Data } \\
0.05 \\
0.09 \\
0.39 \\
\text { No Data } \\
\text { No Data } \\
0.37 \\
\text { No Data } \\
\text { NO.12 } \\
\text { No Data } \\
<0.10 \\
0.63 \\
\text { No Data } \\
0.76 \\
\text { No Data }\end{array}$ & $\begin{array}{l}\text { C12.0 } \\
\text { No Data } \\
\text { <12 0 } \\
\text { No Data } \\
\text { No Data } \\
\text { <16.0 } \\
\text { No Data } \\
\text { <15.6 } \\
\text { No Data } \\
\text { No Data } \\
\text { <15.6 } \\
\text { No Data } \\
\text { No Data } \\
\text { No Data } \\
\text { <15.6 } \\
\text { <13.0 } \\
\text { <13.0 } \\
\text { No Data } \\
\text { No Data } \\
\text { <13.0 } \\
\text { No Data } \\
\text { <13.0 } \\
\text { No Data } \\
\text {-13.6 } \\
\text { 14.7 } \\
\text { No Data } \\
\text { \%15.7 } \\
\text { No Data }\end{array}$ & $\begin{array}{l}40 \\
\text { No Data } \\
2 c \\
\text { No Data } \\
\text { No: Data } \\
36 \\
\text { No Data } \\
26 \\
\text { No Data } \\
\text { No Data } \\
26 \\
\text { No Data } \\
\text { No Data } \\
\text { No Data } \\
14 \\
48 \\
46 \\
\text { No Data } \\
\text { No Data } \\
14 \\
\text { No Data } \\
29 \\
\text { No Data } \\
12 \\
32 \\
\text { No Data } \\
35 \\
\text { No Data }\end{array}$ & $\begin{array}{c}1.9 \\
\text { No Data } \\
8.1 \\
\text { No Data } \\
\text { No Data } \\
10.8 \\
\text { No Data } \\
14.3 \\
\text { No Data } \\
\text { No Data } \\
14.3 \\
\text { No Data } \\
\text { No Data } \\
\text { No bata } \\
8.7 \\
3.7 \\
6.1 \\
\text { No Data } \\
\text { No Data } \\
20.3 \\
\text { No Data } \\
\text { 22.9 } \\
\text { No Data } \\
14.0 \\
8.1 \\
\text { No Data } \\
8.9 \\
\text { No Data }\end{array}$ & $\begin{array}{l}\text { No Detect } \\
\text { No Data } \\
\text { No Detect } \\
\text { No Data } \\
\text { No Detect } \\
\text { No Detect } \\
\text { No Data } \\
\text { No Detect } \\
\text { No Data } \\
\text { No Data } \\
\text { No Detect } \\
\text { No Data } \\
\text { No Data } \\
\text { No Data } \\
\text { No Detect } \\
\text { No Detect } \\
\text { No Detect } \\
\text { No Data } \\
\text { No Data } \\
\text { No Detect } \\
\text { No Data } \\
\text { No Detect } \\
\text { No Data } \\
\text { No Data } \\
\text { No Detect } \\
\text { No Data } \\
\text { No Data } \\
\text { No Data }\end{array}$ & $\begin{array}{c}8.63 \\
\text { No Data } \\
7.24 \\
\text { No Data } \\
\text { No Data } \\
7.96 \\
7.96 \\
7.38 \\
\text { No Data } \\
\text { No Data } \\
8.39 \\
\text { No Data } \\
\text { No Data } \\
\text { No Data } \\
6.58 \\
7.26 \\
\text { No Data } \\
\text { No Data } \\
\text { No Data } \\
6.81 \\
\text { No Data } \\
7.77 \\
\text { No Data } \\
\text { No Data } \\
8.0 \\
\text { No Data } \\
\text { No Data } \\
\text { No Data }\end{array}$ & $\begin{array}{l}330 \\
\text { No Data } \\
95 \\
\text { No Data } \\
<100 \\
97 \\
\text { No Data } \\
80 \\
\text { No Data } \\
\text { No Data } \\
83 \\
\text { No Data } \\
\text { No Data } \\
\text { No Data } \\
125 \\
125 \\
125 \\
\text { No Data } \\
\text { No Data } \\
54 \\
\text { No Data } \\
97 \\
\text { No Data } \\
97 \\
54 \\
\text { No Data } \\
108 \\
\text { No Data }\end{array}$ & $\begin{array}{l}\text { No Data } \\
\text { No Data } \\
\text { No Data } \\
\text { No Data } \\
\text { <40.0 } \\
\text { Mo Data } \\
\text { No Data } \\
\text { No Data } \\
\text { No Data } \\
\text { No Data } \\
\text { No Data } \\
\text { No Data } \\
\text { No Data } \\
\text { No Data } \\
\text { No Data } \\
\text { No Data } \\
\text { No Data } \\
\text { No Data } \\
\text { No Data } \\
\text { No Data } \\
\text { No Data } \\
\text { No Data } \\
\text { No Data } \\
\text { No Data } \\
\text { No Data } \\
\text { No Data } \\
\text { No Data } \\
\text { No Data }\end{array}$ & $\begin{array}{l}\text { No Data } \\
\text { No Data } \\
\text { No Data } \\
\text { No Data } \\
\text { <2.0 } \\
\text { Mo Data } \\
\text { Mo Data } \\
\text { No Data } \\
\text { No Data } \\
\text { No Data } \\
\text { No Data } \\
\text { No Data } \\
\text { No Data } \\
\text { No Data } \\
\text { No Data } \\
\text { Mo Data } \\
\text { No Data } \\
\text { No Data } \\
\text { No Data } \\
\text { No Data } \\
\text { No Data } \\
\text { No Data } \\
\text { No Data } \\
\text { No Data } \\
\text { No Data } \\
\text { No Data } \\
\text { No Data } \\
\text { No Data }\end{array}$ \\
\hline
\end{tabular}

$a_{A}$ "<" symbol indicates that the maximum concentration was below detection limits (number shown is detection limit). A " $"$ indicates an approximate value (the value was outside the limits for which the instrument was calibrated)

bAll sewer effluent samples were collected from manhole \#12 by Geotech, with the exception of sample MLY-953, which was collected at the North Lift S:aiion by the city of Grand Junction. 
Table A-16 (continued). Sewer Effluent Chemistry Data for Grand Junction during 1992a,t

\begin{tabular}{|c|c|c|c|c|c|c|c|c|c|c|}
\hline $\begin{array}{l}\text { Ticket } \\
\text { Number }\end{array}$ & $\begin{array}{c}\text { Sample } s \\
\text { Date }\end{array}$ & $\begin{array}{l}\text { Semivolatile } \\
(\mu \mathrm{g} / \mathrm{L})\end{array}$ & $\underset{(\mathrm{mg} / \mathrm{L})}{\operatorname{IDS}}$ & $\begin{array}{c}\text { Temp } \\
(\operatorname{Deg} C)\end{array}$ & $\prod_{(\mu g / L)}^{I 1}$ & $\begin{array}{c}\text { TOCC } \\
(\mathrm{mg} / \mathrm{L})\end{array}$ & $\begin{array}{c}\operatorname{TOX} \\
(\mathrm{mg} / \mathrm{L})\end{array}$ & $\begin{array}{c}\text { TSS } \\
(\mathrm{mg} / \mathrm{L})\end{array}$ & $\begin{array}{l}\text { Volatile } \\
(\mu g / L)\end{array}$ & $\underset{(\mu g / L)}{Z n}$ \\
\hline $\begin{array}{l}M L Y-465 \\
M L Y-466 \\
M L Y-477 \\
M L Y-478 \\
M L Y-480 \\
M L Y-481 \\
M L Y-482 \\
M L Y-483 \\
M L Y-484 \\
\text { MLY } Y-485 \\
M L Y-490 \\
M L Y-491 \\
M L Y-492 \\
M L Y-493 \\
M L Y-494 \\
M L Y-495 \\
M L Y-496 \\
M L Y-497 \\
M L Y-498 \\
M L Y-499 \\
M L Y-500 \\
M L Y-951 \\
M L Y-952 \\
M L Y-953 \\
M L Y-954 \\
\text { MLY } \\
\text { MLY } Y-955 \\
M L Y-957\end{array}$ & $\begin{array}{l}01 / 09 / 1992 \\
01 / 09 / 1992 \\
02 / 13 / 1992 \\
02 / 13 / 1992 \\
02 / 24 / 1992 \\
03 / 11 / 1992 \\
03 / 11 / 1992 \\
04 / 08 / 1992 \\
04 / 08 / 1992 \\
04 / 08 / 1992 \\
05 / 07 / 1: 92 \\
05 / 07 / 1952 \\
05 / 07 / 1992 \\
05 / 07 / 1992 \\
05 / 14 / 1992 \\
06 / 04 / 1992 \\
06 / 04 / 1992 \\
06 / 04 / 1992 \\
06 / 04 / 1992 \\
07 / 07 / 1992 \\
07 / 07 / 1992 \\
08 / 06 / 1992 \\
08 / 06 / 1992 \\
10 / 19 / 1992 \\
12 / 17 / 1992 \\
12 / 17 / 1992 \\
12 / 17 / 1992 \\
12 / 17 / 1992\end{array}$ & $\begin{array}{l}\text { No Data } \\
\text { No Data } \\
\text { No Data } \\
\text { No Data } \\
\text { See Table } \\
\text { No Data } \\
\text { No Data } \\
\text { No Data } \\
\text { No Data } \\
\text { No Data } \\
\text { No Data } \\
\text { No Data } \\
\text { No Data } \\
\text { No Data } \\
\text { No Data } \\
\text { No Data } \\
\text { No Data } \\
\text { No Data } \\
\text { No Data } \\
\text { No Data } \\
\text { No Data } \\
\text { No Data } \\
\text { No Data } \\
\text { No Data } \\
\text { No Data } \\
\text { No Data } \\
\text { No Data } \\
\text { No Data }\end{array}$ & $\begin{array}{l}390 \\
\text { No Data } \\
280 \\
\text { No Data } \\
\text { No Data } \\
460 \\
\text { No Data } \\
490 \\
\text { No Data } \\
\text { No Data } \\
310 \\
\text { No Data } \\
\text { No Data } \\
\text { No Data } \\
\text { No Data } \\
280 \\
280 \\
\text { No Data } \\
\text { No Data } \\
290 \\
\text { No Data } \\
236 \\
\text { No Data } \\
380 \\
1080 \\
\text { No Data } \\
1080 \\
\text { No Data }\end{array}$ & $\begin{array}{l}12.2 \\
\text { No Data } \\
12.2 \\
\text { Nc Data } \\
\text { No Data } \\
13.0 \\
13.0 \\
15.9 \\
\text { No Data } \\
\text { No Data } \\
18.8 \\
\text { No Data } \\
\text { No Data } \\
\text { No Data } \\
21.7 \\
20.5 \\
\text { No Data } \\
\text { No Data } \\
\text { No Data } \\
23.0 \\
\text { No Data } \\
23.7 \\
\text { No Data } \\
\text { No Data } \\
21.5 \\
\text { No Data } \\
\text { No Data } \\
\text { No Data }\end{array}$ & $\begin{array}{l}\text { No Dat: } \\
\text { No Data } \\
\text { No Data } \\
\text { No Data } \\
\text { <4.0 } \\
\text { No Data } \\
\text { No Data } \\
\text { No Data } \\
\text { No Data } \\
\text { No Data } \\
\text { No Data } \\
\text { No Data } \\
\text { No Data } \\
\text { No Data } \\
\text { No Data } \\
\text { No Data } \\
\text { No Data } \\
\text { No Data } \\
\text { No Data } \\
\text { No Data } \\
\text { No Data } \\
\text { No Data } \\
\text { No Data } \\
\text { No Data } \\
\text { No Data } \\
\text { No Data } \\
\text { No Data } \\
\text { No Data }\end{array}$ & $\begin{array}{l}75.7 \\
\text { No Data } \\
42.5 \\
\text { No Data } \\
\text { No Data } \\
74.4 \\
\text { No Data } \\
109 \\
\text { No Data } \\
\text { No Data } \\
56.7 \\
\text { No Data } \\
\text { No Data } \\
\text { No Data } \\
\text { No Data } \\
52.5 \\
51.2 \\
\text { No Data } \\
\text { No Data } \\
98.7 \\
\text { No Data } \\
24.4 \\
\text { No Data } \\
\text { No Data } \\
677 \\
\text { No Data } \\
704 \\
\text { No Data }\end{array}$ & $\begin{array}{c}0.14 \\
\text { No Data } \\
0.05 \\
\text { No Data } \\
\text { No Data } \\
0.10 \\
\text { No Data } \\
0.06 \\
\text { No Data } \\
\text { No Data } \\
\text { No Data } \\
\text { No Data } \\
\text { No Data } \\
\text { No Data } \\
\text { No Data } \\
\text { No Data } \\
\text { O.13 } \\
\text { No Data } \\
\text { No Data } \\
\text { O.20 } \\
\text { No Data } \\
0.02 \\
\text { No Data } \\
\text { No Data } \\
\text { O.04 } \\
\text { No Data } \\
\text { No Data } \\
\text { No Data }\end{array}$ & $\begin{array}{l}58 \\
\text { No Data } \\
14 \\
\text { No Data } \\
\text { No Data } \\
38 \\
\text { No Data } \\
83 \\
\text { No Data } \\
\text { No Data } \\
53 \\
\text { No Data } \\
\text { No Data } \\
\text { No Data } \\
64 \\
50 \\
50 \\
\text { No Data } \\
\text { No Data } \\
250 \\
\text { No Data } \\
20 \\
\text { No Data } \\
167 \\
696 \\
\text { No Data } \\
674 \\
\text { No Data }\end{array}$ & $\begin{array}{l}\text { No Data } \\
\text { No Data } \\
\text { No Data } \\
\text { No Data } \\
\text { See Table } \\
\text { No Data } \\
\text { No Data } \\
\text { No Data } \\
\text { No Data } \\
\text { No Data } \\
\text { No Data } \\
\text { No Data } \\
\text { No Data } \\
\text { No Data } \\
\text { No Data } \\
\text { No Data } \\
\text { No Data } \\
\text { No Data } \\
\text { No Data } \\
\text { No Data } \\
\text { No Data } \\
\text { No Data } \\
\text { No Data } \\
\text { No Data } \\
\text { No Data } \\
\text { No Data } \\
\text { No Data } \\
\text { No Data }\end{array}$ & $\begin{array}{l}457 \\
\text { Ho Data } \\
413 \\
\text { No Data } \\
540 \\
422 \\
\text { No Data } \\
572 \\
\text { No Data } \\
\text { No Data } \\
\text {-462 } \\
\text { No Data } \\
\text { No Data } \\
\text { No Data } \\
522 \\
606 \\
653 \\
\text { No Data } \\
\text { No Data } \\
1060 \\
\text { No Data } \\
302 \\
\text { No Data } \\
639 \\
842 \\
\text { No Data } \\
919 \\
\text { No Data }\end{array}$ \\
\hline
\end{tabular}

$a_{A} "<"$ symbol indicates that the maximum concentration was below detection limits (number shown is detection limit). A " " indicates an approximate value (the value was outside the limits for which the instrument was calibrated).

ball sewer effluent samples were collected from manhole $\$ 12$ by Geotech, with the exception of sample MLY-953, which was collected at the North Lift Station by the city of Grand Junction.

cTotal organic carbon. 
Table A-17. Sewer Effluent Chemistry Data for Grand Junction during 1992, Organicsa

\begin{tabular}{|c|c|c|c|c|c|c|c|c|c|c|}
\hline $\begin{array}{l}\text { Ticket } \\
\text { Number }\end{array}$ & $\begin{array}{l}\text { Sample } \\
\text { Date }\end{array}$ & $\begin{array}{c}103-82-2 \\
(\mu g / L)\end{array}$ & $\begin{array}{c}106-44-5 \\
(\mu \mathrm{g} / \mathrm{L})\end{array}$ & $\begin{array}{c}117-81-7 \\
(\mu g / L)\end{array}$ & $\begin{array}{c}143-07-7 \\
(\mu \mathrm{g} / \mathrm{L})\end{array}$ & $\begin{array}{c}26265-99-6 \\
(\mu g / L)\end{array}$ & $\begin{array}{c}544-63-8 \\
(\mu g / L)\end{array}$ & $\begin{array}{r}57-10-3 \\
(\mu g / L)\end{array}$ & $\begin{array}{r}57-11-4 \\
(\mu g / L)\end{array}$ & $\begin{array}{r}57-88-5 \\
(\mathrm{pg} / \mathrm{L})\end{array}$ \\
\hline 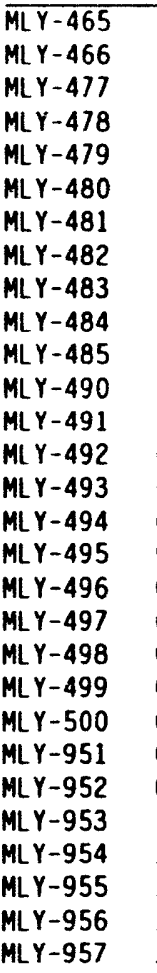 & $\begin{array}{l}01 / 09 / 1992 \\
01 / 09 / 1992 \\
02 / 13 / 1992 \\
02 / 13 / 1992 \\
02 / 13 / 1992 \\
02 / 24 / 1992 \\
03 / 11 / 1992 \\
03 / 11 / 1992 \\
04 / 08 / 1992 \\
04 / 08 / 1992 \\
04 / 08 / 1992 \\
05 / 07 / 1992 \\
05 / 07 / 1992 \\
05 / 07 / 1992 \\
05 / 07 / 1992 \\
05 / 14 / 1992 \\
06 / 04 / 1992 \\
06 / 04 / 1992 \\
06 / 04 / 1992 \\
06 / 04 / 1992 \\
07 / 07 / 1992 \\
07 / 07 / 1992 \\
08 / 06 / 1992 \\
08 / 06 / 1992 \\
10 / 19 / 1992 \\
12 / 17 / 1992 \\
12 / 17 / 1992 \\
12 / 17 / 1992 \\
12 / 17 / 1992\end{array}$ & $\begin{array}{l}\text { No Data } \\
\text { No Data } \\
\text { No Data } \\
\text { No Data } \\
\text { No Data } \\
22 \\
\text { No Data } \\
\text { No Data } \\
\text { No Oata } \\
\text { No Data } \\
\text { No Data } \\
\text { No Data } \\
\text { No Data } \\
\text { No Data } \\
\text { No Data } \\
\text { No Data } \\
\text { No Data } \\
\text { No Data } \\
\text { No Data } \\
\text { No Data } \\
\text { No Data } \\
\text { No Data } \\
\text { No Data } \\
\text { No Data } \\
\text { No Data } \\
\text { No Data } \\
\text { No Data } \\
\text { No Data } \\
\text { No Data }\end{array}$ & $\begin{array}{l}\text { No Data } \\
\text { No Data } \\
\text { No Data } \\
\text { No Data } \\
\text { No Data } \\
29 \\
\text { No Data } \\
\text { No Data } \\
\text { No Data } \\
\text { No Data } \\
\text { No Data } \\
\text { No Data } \\
\text { No Data } \\
\text { No Data } \\
\text { No Data } \\
\text { No Data } \\
\text { No Data } \\
\text { No Data } \\
\text { No Data } \\
\text { No Data } \\
\text { No Data } \\
\text { No Data } \\
\text { No Data } \\
\text { No Data } \\
\text { No Data } \\
\text { No Data } \\
\text { No Data } \\
\text { No Data } \\
\text { No Data }\end{array}$ & $\begin{array}{l}\text { No Data } \\
\text { No Data } \\
\text { No Data } \\
\text { No Data } \\
\text { No Data } \\
86 \\
\text { No Data } \\
\text { No Data } \\
\text { No Data } \\
\text { No Data } \\
\text { No Data } \\
\text { No Data } \\
\text { No Data } \\
\text { No Data } \\
\text { No Data } \\
\text { No Data } \\
\text { No Data } \\
\text { No Data } \\
\text { No Data } \\
\text { No Data } \\
\text { No Data } \\
\text { Ho Data } \\
\text { No Data } \\
\text { No Data } \\
\text { No Data } \\
\text { No Data } \\
\text { No Data } \\
\text { No Data } \\
\text { No Data }\end{array}$ & $\begin{array}{l}\text { No Data } \\
\text { No Data } \\
\text { No Data } \\
\text { No Data } \\
\text { No Data } \\
34 \\
\text { No Data } \\
\text { No Data } \\
\text { No Data } \\
\text { No Data } \\
\text { No Data } \\
\text { No Data } \\
\text { No Data } \\
\text { No Data } \\
\text { No Data } \\
\text { No Data } \\
\text { No Data } \\
\text { No Data } \\
\text { No Data } \\
\text { No Data } \\
\text { No Data } \\
\text { No Data } \\
\text { No Data } \\
\text { No Data } \\
\text { No Data } \\
\text { No Data } \\
\text { No Data } \\
\text { No Data } \\
\text { No Data }\end{array}$ & $\begin{array}{l}\text { No Data } \\
\text { No Data } \\
\text { No Data } \\
\text { No Data } \\
\text { No Data } \\
22 \\
\text { No Data } \\
\text { No Data } \\
\text { No Data } \\
\text { No Data } \\
\text { No Data } \\
\text { No Data } \\
\text { No Data } \\
\text { No Data } \\
\text { No Data } \\
\text { No Data } \\
\text { No Jata } \\
\text { No Data } \\
\text { No Data } \\
\text { No Data } \\
\text { No Data } \\
\text { No Data } \\
\text { No Data } \\
\text { No Data } \\
\text { No Data } \\
\text { No Data } \\
\text { No Data } \\
\text { No Data } \\
\text { No Data }\end{array}$ & $\begin{array}{l}\text { No Data } \\
\text { No Data } \\
\text { No Data } \\
\text { No Data } \\
\text { No Data } \\
50 \\
\text { No Data } \\
\text { No Data } \\
\text { No Data } \\
\text { No Data } \\
\text { No Data } \\
\text { No Data } \\
\text { No Data } \\
\text { No Data } \\
\text { No Data } \\
\text { No Data } \\
\text { No Data } \\
\text { No Data } \\
\text { No Data } \\
\text { No Data } \\
\text { No Data } \\
\text { No Data } \\
\text { No Data } \\
\text { No Data } \\
\text { No Data } \\
\text { No Data } \\
\text { No Data } \\
\text { No Data } \\
\text { No Data }\end{array}$ & $\begin{array}{l}\text { No Data } \\
\text { No Data } \\
\text { No Data } \\
\text { No Data } \\
\text { No Data } \\
900 \\
\text { No Data } \\
\text { No Data } \\
\text { No Data } \\
\text { No Data } \\
\text { No Data } \\
\text { No Data } \\
\text { No Data } \\
\text { No Data } \\
\text { No Data } \\
\text { No Data } \\
\text { No Data } \\
\text { No Data } \\
\text { No Data } \\
\text { No Data } \\
\text { No Data } \\
\text { No Data } \\
\text { No Data } \\
\text { No Data } \\
\text { No Data } \\
\text { No Data } \\
\text { No Data } \\
\text { No Data } \\
\text { No Data }\end{array}$ & $\begin{array}{l}\text { No Data } \\
\text { No Data } \\
\text { No Data } \\
\text { No Data } \\
\text { No Data } \\
1600 \\
\text { No Data } \\
\text { No Data } \\
\text { No Data } \\
\text { No Data } \\
\text { No Data } \\
\text { No Data } \\
\text { No Data } \\
\text { No Data } \\
\text { No Data } \\
\text { No Data } \\
\text { No Data } \\
\text { No Data } \\
\text { No Data } \\
\text { No Data } \\
\text { No Data } \\
\text { No Data } \\
\text { No Data } \\
\text { No Data } \\
\text { No Data } \\
\text { No Data } \\
\text { No Data } \\
\text { No Data } \\
\text { No Data }\end{array}$ & $\begin{array}{l}\text { No Data } \\
\text { No Data } \\
\text { No Data } \\
\text { No Data } \\
\text { No Data } \\
40 \\
\text { No Data } \\
\text { No Data } \\
\text { No Data } \\
\text { No Data } \\
\text { No Data } \\
\text { No Data } \\
\text { No Data } \\
\text { No Data } \\
\text { No Data } \\
\text { No Data } \\
\text { No Data } \\
\text { No Data } \\
\text { No Data } \\
\text { No Data } \\
\text { No Data } \\
\text { No Data } \\
\text { No Data } \\
\text { No Data } \\
\text { No Data } \\
\text { No Data } \\
\text { No Data } \\
\text { No Data } \\
\text { No Data }\end{array}$ \\
\hline
\end{tabular}

aCAS Number 103-82-2 Benzeneacetic acid

CAS Number 106-44-5 4-Methylphenol

CAS Number 117-81-7 Bis(2-ethylhexyl)phthalate

CAS Number 143-07-7 Dodecanoic acid

CAS Number 26265-99-6 Heptadecenoic acid

CAS Number 544-63-8 Tetradecanoic acid

CAS Number 57-10-3 Hexadecanoic acid

CAS Number 57-11-4 Octadecanoic acid

CAS Number 57-88-5 Cholesterol 
Table A-17 (continued). Sewer Effluent Chemistry Data for Grand Junction during 1992, Organicsa

\begin{tabular}{|c|c|c|c|c|c|c|c|c|c|c|}
\hline $\begin{array}{l}\text { Ticket } \\
\text { Number }\end{array}$ & $\begin{array}{c}\text { Sample } \\
\text { Date }\end{array}$ & $\begin{array}{r}58-08-2 \\
(\mu g / L)\end{array}$ & $\begin{array}{r}59-02-9 \\
(\mu \mathrm{g} / \mathrm{L})\end{array}$ & $\begin{array}{r}65-85-0 \\
(\mu \mathrm{g} / \mathrm{L})\end{array}$ & $\begin{array}{r}67-64-1 \\
(\mu \mathrm{g} / \mathrm{L})\end{array}$ & $\begin{array}{r}75-09-2 \\
(\mu \mathrm{g} / \mathrm{L})\end{array}$ & $\begin{array}{c}\text { UNK-17.02 } \\
(\mu \mathrm{g} / \mathrm{L})\end{array}$ & $\begin{array}{c}\text { UNK- } 20.77 \\
(\mu \mathrm{g} / \mathrm{L})\end{array}$ & $\begin{array}{l}\text { UNK-22.59 } \\
(\mu \mathrm{g} / \mathrm{L})\end{array}$ & $\begin{array}{c}\text { UNK-26.19 } \\
(\mu g / L)\end{array}$ \\
\hline $\begin{array}{l}\text { MLY } Y-465 \\
M L Y-466 \\
M L Y-477 \\
M L Y-478 \\
M L Y-479 \\
M L Y-490 \\
M L Y-481 \\
M L Y-482 \\
M L Y-483 \\
\text { MLY } Y-484 \\
M L Y-485 \\
M L Y-490 \\
M L Y-491 \\
M L Y-492 \\
M L Y-493 \\
M L Y-494 \\
M L Y-495 \\
M L Y-496 \\
M L Y-497 \\
M L Y-498 \\
M L Y-499 \\
M L Y-500 \\
M L Y-951 \\
M L Y-952 \\
M L Y-953 \\
M L Y-954 \\
M L Y-955 \\
M L Y-956 \\
M L Y-957\end{array}$ & $\begin{array}{l}01 / 09 / 1992 \\
01 / 09 / 1992 \\
02 / 13 / 1992 \\
02 / 13 / 1992 \\
02 / 13 / 1992 \\
02 / 24 / 1992 \\
03 / 11 / 1992 \\
03 / 11 / 1992 \\
04 / 08 / 1992 \\
04 / 08 / 1992 \\
04 / 08 / 1992 \\
05 / 07 / 1992 \\
05 / 07 / 1992 \\
05 / 07 / 1992 \\
05 / 07 / 1992 \\
05 / 14 / 1992 \\
06 / 04 / 1992 \\
06 / 04 / 1992 \\
06 / 04 / 1992 \\
06 / 04 / 1992 \\
07 / 07 / 1992 \\
07 / 07 / 1992 \\
08 / 06 / 1992 \\
08 / 06 / 1992 \\
10 / 19 / 1992 \\
12 / 17 / 1992 \\
12 / 17 / 1992 \\
12 / 17 / 1992 \\
12 / 17 / 1992\end{array}$ & $\begin{array}{l}\text { No Data } \\
\text { No Data } \\
\text { No Data } \\
\text { No Data } \\
\text { No Data } \\
74 \\
\text { No Data } \\
\text { No Data } \\
\text { No Data } \\
\text { No Data } \\
\text { No Data } \\
\text { No Data } \\
\text { No Data } \\
\text { No Data } \\
\text { No Data } \\
\text { No Data } \\
\text { No Data } \\
\text { No Data } \\
\text { No Data } \\
\text { No Data } \\
\text { No Data } \\
\text { No Data } \\
\text { No Data } \\
\text { No Data } \\
\text { No Data } \\
\text { No Data } \\
\text { No Data } \\
\text { No Data } \\
\text { No Data }\end{array}$ & $\begin{array}{l}\text { No Data } \\
\text { No Data } \\
\text { No Data } \\
\text { No Data } \\
\text { No Data } \\
\text { 10 } \\
\text { No Data } \\
\text { No Data } \\
\text { No Data } \\
\text { No Data } \\
\text { No Data } \\
\text { No Data } \\
\text { No Data } \\
\text { No Data } \\
\text { No Data } \\
\text { No Data } \\
\text { No Data } \\
\text { No Data } \\
\text { No Data } \\
\text { No Data } \\
\text { No Data } \\
\text { No Data } \\
\text { No Data } \\
\text { No Data } \\
\text { No Data } \\
\text { No Data } \\
\text { No Data } \\
\text { No Data } \\
\text { No Data }\end{array}$ & $\begin{array}{l}\text { No Data } \\
\text { No Data } \\
\text { No Data } \\
\text { No Data } \\
\text { No Data } \\
76 \\
\text { No Data } \\
\text { No Data } \\
\text { No Data } \\
\text { No Data } \\
\text { No Data } \\
\text { No Data } \\
\text { No Data } \\
\text { No Data } \\
\text { No Data } \\
\text { No Data } \\
\text { No Data } \\
\text { No Data } \\
\text { No Data } \\
\text { No Data } \\
\text { No Data } \\
\text { No Data } \\
\text { No Data } \\
\text { No Data } \\
\text { No Data } \\
\text { No Data } \\
\text { No Data } \\
\text { No Data } \\
\text { No Data }\end{array}$ & $\begin{array}{l}\text { No Data } \\
\text { No Data } \\
\text { No Data } \\
\text { No Data } \\
\text { No Data } \\
69 \\
\text { No Data } \\
\text { No Data } \\
\text { No Data } \\
\text { No Data } \\
\text { No Data } \\
\text { No Data } \\
\text { No Data } \\
\text { No Data } \\
\text { No Data } \\
\text { No Data } \\
\text { No Data } \\
\text { No Data } \\
\text { No Data } \\
\text { No Data } \\
\text { No Data } \\
\text { No Data } \\
\text { No Data } \\
\text { No Data } \\
\text { No Data } \\
\text { No Data } \\
\text { No Data } \\
\text { No Data } \\
\text { No Data }\end{array}$ & $\begin{array}{l}\text { No Data } \\
\text { No Data } \\
\text { No Data } \\
\text { No Data } \\
\text { No Data } \\
8700 \\
\text { No Data } \\
\text { No Data } \\
\text { No Data } \\
\text { No Data } \\
\text { No Data } \\
\text { No Data } \\
\text { No Data } \\
\text { No Data } \\
\text { No Data } \\
\text { No Data } \\
\text { No Data } \\
\text { No Data } \\
\text { No Data } \\
\text { No Data } \\
\text { No Data } \\
\text { No Data } \\
\text { No Data } \\
\text { No Data } \\
\text { No Data } \\
\text { No Data } \\
\text { No Data } \\
\text { No Data } \\
\text { No Data }\end{array}$ & $\begin{array}{l}\text { No Data } \\
\text { No Data } \\
\text { No Data } \\
\text { No Data } \\
\text { No Data } \\
10 \\
\text { No Data } \\
\text { No Data } \\
\text { No Data } \\
\text { No Data } \\
\text { No Data } \\
\text { No Data } \\
\text { No Data } \\
\text { No Data } \\
\text { No Data } \\
\text { No Data. } \\
\text { No Data } \\
\text { No Data } \\
\text { No Data } \\
\text { No Data } \\
\text { No Data } \\
\text { No Data } \\
\text { No Data } \\
\text { No Data } \\
\text { No Data } \\
\text { No Data } \\
\text { No Data } \\
\text { No Data } \\
\text { No Data }\end{array}$ & $\begin{array}{l}\text { No Data } \\
\text { No Data } \\
\text { No Data } \\
\text { No Data } \\
\text { No Data } \\
13 \\
\text { No Data } \\
\text { No Data } \\
\text { No Data } \\
\text { No Data } \\
\text { No Data } \\
\text { Mo Data } \\
\text { No Data } \\
\text { Mo Data } \\
\text { No Data } \\
\text { No Data } \\
\text { No Data } \\
\text { No Data } \\
\text { No Data } \\
\text { Mo Data } \\
\text { No Data } \\
\text { No Data } \\
\text { No Data } \\
\text { No Data } \\
\text { No Data } \\
\text { No Data } \\
\text { No Data } \\
\text { No Data } \\
\text { No Data }\end{array}$ & $\begin{array}{l}\text { No Data } \\
\text { No Data } \\
\text { No Data } \\
\text { No Data } \\
\text { No Data } \\
40 \\
\text { No Data } \\
\text { No Data } \\
\text { No Data } \\
\text { No Data } \\
\text { No Data } \\
\text { No Data } \\
\text { No Data } \\
\text { No Data } \\
\text { No Data } \\
\text { No Data } \\
\text { No Data } \\
\text { No Data } \\
\text { No Data } \\
\text { No Data } \\
\text { No Data } \\
\text { No Data } \\
\text { No Data } \\
\text { No Data } \\
\text { No Data } \\
\text { No Data } \\
\text { No Data } \\
\text { No Data } \\
\text { No Data }\end{array}$ & $\begin{array}{l}\text { No Data } \\
\text { No Data } \\
\text { No Data } \\
\text { No Data } \\
\text { No Data } \\
1100 \\
\text { No Data } \\
\text { No Data } \\
\text { No Data } \\
\text { No Data } \\
\text { No Data } \\
\text { No Data } \\
\text { No Data } \\
\text { No Data } \\
\text { No Data } \\
\text { No Data } \\
\text { No Data } \\
\text { No Data } \\
\text { No Data } \\
\text { No Data } \\
\text { No Data } \\
\text { No Data } \\
\text { No Data } \\
\text { No Data } \\
\text { No Data } \\
\text { No Data } \\
\text { No Data } \\
\text { No Data } \\
\text { No Data }\end{array}$ \\
\hline
\end{tabular}

$\begin{array}{lll}\text { aCAS Number } & 58-08-2 & \text { Caffeine } \\ & \text { CAS Number } 59-02-9 & \text { Vitamin }\end{array}$

CAS Number 65-85-0 Benzoic acid

CAS Number 67-64-1 Acetone

CAS Number $75-09-2$ Methylene chloride

CAS Number UNK-17.02 Unknown organic acid

CAS Number UNK-20.77 Unknown

CAS Number UNK-22.59 Unknown

CAS Number UNK-26.19 Unknown organic acid 
Table A-17 (continued). Sewer Effluent Chemistry Data for Grand Junction during 1992, Organics

\begin{tabular}{lll}
\hline $\begin{array}{c}\text { Ticket } \\
\text { Number }\end{array}$ & $\begin{array}{c}\text { Sample } \\
\text { Date }\end{array}$ & $\begin{array}{c}\text { UNK-30.19 } \\
\text { (pog/L) }\end{array}$ \\
MLY-465 & $01 / 09 / 1992$ & No Data \\
MLY-466 & $01 / 109 / 1992$ & No Data \\
MLY-477 & $02 / 13 / 1992$ & No Data \\
MLY-478 & $02 / 13 / 1992$ & No Data \\
MLY-479 & $02 / 13 / 1992$ & No Data \\
MLY-480 & $02 / 24 / 1992$ & 17 \\
MLY-481 & $03 / 11 / 1992$ & No Data \\
MLY-482 & $03 / 11 / 1992$ & No Data \\
MLY-483 & $04 / 08 / 1992$ & No Data \\
MLY-484 & $04 / 08 / 1992$ & No Data \\
MLY-485 & $04 / 08 / 1992$ & No Data \\
MLY-490 & $05 / 07 / 1992$ & No Data \\
MLY-491 & $05 / 07 / 1992$ & No Data \\
MLY-492 & $05 / 07 / 1992$ & No Data \\
MLY-493 & $05 / 07 / 1992$ & No Data \\
MLY-494 & $05 / 14 / 1992$ & No Data \\
MLY-495 & $06 / 04 / 1992$ & No Data \\
MLY-496 & $06 / 04 / 1992$ & No Data \\
MLY-497 & $06 / 04 / 1992$ & No Data \\
MLY-498 & $06 / 04 / 1992$ & No Data \\
MLY-499 & $07 / 07 / 1992$ & No Data \\
MLY-500 & $07 / 07 / 1992$ & No Data \\
MLY-951 & $08 / 06 / 1992$ & No Data \\
MLY-952 & $08 / 06 / 1992$ & No Data \\
MLY-953 & $10 / 19 / 1992$ & No Data \\
MLY-954 & $12 / 17 / 1992$ & No Data \\
MLY-955 & $12 / 17 / 1992$ & No Data \\
MLY-956 & $12 / 17 / 1992$ & No Data \\
YLY-957 & $12 / 17 / 1992$ & No Data \\
& & \\
\hline
\end{tabular}

aCAS Number UNK-30.19 Unknown 
Table A-18. Water Chemistry Data for Grand Junction, March 16 through March 18, 1992a

\begin{tabular}{|c|c|c|c|c|c|c|c|c|c|c|c|}
\hline $\begin{array}{l}\text { Sample } \\
\text { Location }\end{array}$ & $\begin{array}{l}\text { Ticket } \\
\text { Number }\end{array}$ & $\begin{array}{l}\text { Sample } \\
\text { Date }\end{array}$ & $\begin{array}{c}\text { Alkyb } \\
(\mathrm{ppm}) \\
(\mathrm{as} \mathrm{CaCO})\end{array}$ & $\begin{array}{c}\text { Alpha } \\
(\mathrm{pCi} / \mathrm{L})^{\mathrm{C}}\end{array}$ & $\begin{array}{c}\text { As } \\
(\mu g / L)\end{array}$ & $\underset{(\mu \mathrm{Ba} / \mathrm{L})}{\mathrm{Ba}}$ & $\underset{(\mu g / L)}{C a}$ & $\underset{(\mu g / L)}{C d}$ & $\begin{array}{c}\text { cotd } \\
\left(\mu_{\text {minos } / \mathrm{cm}}\right)^{\mathrm{e}}\end{array}$ & $\underset{(\mu g / L)}{c 1}$ & $\underset{(\mu g / L)}{C r}$ \\
\hline \multicolumn{12}{|l|}{ Ground Water } \\
\hline $\begin{array}{l}1-9 S A \\
10-19 N \\
11-1 S \\
13-16 N A \\
13-16 N A \quad \text { (Dup) } \\
14-13 N A \\
14-6 N A \\
3-3 N A \\
5-12 N A \\
\text { GJ84-04 } \\
\text { GJ84-05 } \\
\text { GJ84-06 } \\
\text { GJ84-09 } \\
\text { GJ84-10 } \\
P-2 A \\
P-3 A \\
P-4 A \\
P-6\end{array}$ & 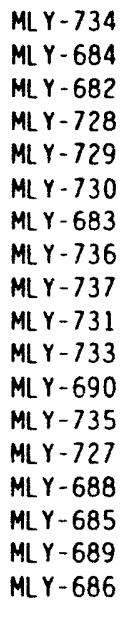 & $\begin{array}{l}03 / 18 / 1992 \\
03 / 17 / 1992 \\
03 / 17 / 1992 \\
03 / 17 / 1992 \\
03 / 17 / 1992 \\
03 / 17 / 1992 \\
03 / 17 / 1992 \\
03 / 18 / 1992 \\
03 / 18 / 1992 \\
03 / 17 / 1992 \\
03 / 17 / 1992 \\
03 / 18 / 1992 \\
03 / 18 / 1992 \\
03 / 16 / 1992 \\
03 / 18 / 1992 \\
03 / 17 / 1992 \\
03 / 18 / 1992 \\
03 / 18 / 1992\end{array}$ & $\begin{array}{l}257 \\
405 \\
312 \\
501 \\
\text { No Data } \\
\text { No Data } \\
257 \\
336 \\
319 \\
388 \\
452 \\
278 \\
260 \\
146 \\
226 \\
318 \\
352 \\
246\end{array}$ & $\begin{array}{r}<140 \\
800 \\
600 \\
470 \\
440 \\
510 \\
220 \\
<200 \\
<150 \\
<160 \\
1500 \\
<150 \\
<150 \\
<150 \\
<160 \\
570 \\
500 \\
<140\end{array}$ & $\begin{array}{l}<2.0 \\
<20.0 \\
<2.0 \\
<2.9 \\
<2.0 \\
11.3 \\
250 \\
<2.0 \\
<2.0 \\
12.3 \\
<2.0 \\
<2.0 \\
<2.0 \\
<2.0 \\
<2.0 \\
<2.0 \\
<2.0 \\
<2.0\end{array}$ & $\begin{array}{r}-17.1 \\
-12.2 \\
-31.3 \\
-13.8 \\
-14.3 \\
-12.8 \\
-62.7 \\
-15.6 \\
-15.2 \\
-23.1 \\
-26.4 \\
-24.6 \\
-12.1 \\
-5.4 \\
-17.9 \\
-35.5 \\
-14.8 \\
-17.0\end{array}$ & $\begin{array}{r}107000 \\
464000 \\
228000 \\
354000 \\
357000 \\
262000 \\
130000 \\
795000 \\
298000 \\
223000 \\
546000 \\
369000 \\
126000 \\
128000 \\
294000 \\
287000 \\
395000 \\
79700\end{array}$ & $\begin{array}{l}<1.0 \\
<1.0 \\
<1.0 \\
<1.0 \\
<1.0 \\
<1.0 \\
<1.0 \\
<1.0 \\
<1.0 \\
<1.0 \\
<1.0 \\
<1.0 \\
<1.0 \\
<1.0 \\
<1.0 \\
<1.0 \\
<1.0 \\
<1.0\end{array}$ & $\begin{array}{l}1980 \\
8000 \\
3140 \\
4350 \\
\text { No Data } \\
2951 \\
1311 \\
7320 \\
3220 \\
3987 \\
7680 \\
2780 \\
2380 \\
2660 \\
3480 \\
2450 \\
6170 \\
1767\end{array}$ & $\begin{array}{r}19500 \\
608000 \\
114000 \\
191000 \\
190000 \\
139000 \\
19600 \\
1050000 \\
160000 \\
141000 \\
487000 \\
188000 \\
49100 \\
105000 \\
230000 \\
65300 \\
454000 \\
20400\end{array}$ & $\begin{array}{l}<4.0 \\
<4.0 \\
<4.0 \\
<4.0 \\
<4.0 \\
<4.0 \\
<4.0 \\
<4.0 \\
<4.0 \\
<4.0 \\
<4.0 \\
<4.0 \\
<4.0 \\
<4.0 \\
<4.0 \\
<4.0 \\
<4.0 \\
<4.0\end{array}$ \\
\hline \multicolumn{12}{|l|}{ Surface Mater } \\
\hline $\begin{array}{l}\text { Lower Gunnison } \\
\text { Middle Gunnison } \\
\text { North Pond } \\
\text { South Pond } \\
\text { Upper Gunnison } \\
\text { Upper Mid Gunnison }\end{array}$ & $\begin{array}{l}M L Y-726 \\
M L Y-677 \\
M L Y-679 \\
M L Y-680 \\
M L Y-678 \\
M L Y-681\end{array}$ & $\begin{array}{l}03 / 16 / 1992 \\
03 / 16 / 1992 \\
03 / 16 / 1992 \\
03 / 16 / 1992 \\
03 / 16 / 1992 \\
03 / 16 / 1992\end{array}$ & $\begin{array}{l}136 \\
136 \\
273 \\
154 \\
162 \\
143\end{array}$ & $\begin{array}{r}<50 \\
<50 \\
440 \\
210 \\
70 \\
<50\end{array}$ & $\begin{array}{l}<2.0 \\
-2.9 \\
\sim 2.7 \\
14.7 \\
-2.1 \\
<2.0\end{array}$ & $\begin{array}{l}\sim 41.3 \\
-41.4 \\
-13.7 \\
-13.8 \\
-40.0 \\
-45.2\end{array}$ & $\begin{array}{r}91500 \\
87700 \\
282000 \\
316000 \\
88000 \\
89200\end{array}$ & $\begin{array}{l}<1.0 \\
<1.0 \\
<1.0 \\
<1.0 \\
<1.0 \\
<1.0\end{array}$ & $\begin{array}{r}1008 \\
888 \\
3670 \\
3050 \\
887 \\
864\end{array}$ & $\begin{array}{r}13100 \\
8700 \\
275000 \\
177000 \\
8590 \\
9100\end{array}$ & $\begin{array}{l}<4.0 \\
<4.0 \\
<4.0 \\
<4.0 \\
<4.0 \\
<4.0\end{array}$ \\
\hline \multicolumn{12}{|l|}{ QA/QC } \\
\hline $\begin{array}{l}\text { Equipment Blank } \\
\text { Trip Blank } \\
\text { Trip } 81 \text { lank }\end{array}$ & $\begin{array}{l}\text { MLY Y } 732 \\
\text { MLY }-676 \\
\text { MLY }-687\end{array}$ & $\begin{array}{l}03 / 17 / 1992 \\
03 / 16 / 1992 \\
03 / 18 / 1992\end{array}$ & $\begin{array}{l}\text { No Data } \\
\text { No Data } \\
\text { No Data }\end{array}$ & $\begin{array}{l}<30 \\
\text { No Data } \\
\text { No Data }\end{array}$ & $\begin{array}{l}<2.0 \\
\text { No Data } \\
\text { No Data }\end{array}$ & $\begin{array}{l}<5.0 \\
\text { No Data } \\
\text { No Data }\end{array}$ & $\begin{array}{l}<14.0 \\
\text { No Data } \\
\text { No Data }\end{array}$ & $\begin{array}{l}<1.0 \\
\text { No Data } \\
\text { No Data }\end{array}$ & $\begin{array}{l}\text { Mo Data } \\
\text { No Data } \\
\text { No Data }\end{array}$ & $\begin{array}{l}-59.5 \\
\text { No Data } \\
\text { No Data }\end{array}$ & $\begin{array}{l}<4.0 \\
\text { No Data } \\
\text { No Data }\end{array}$ \\
\hline
\end{tabular}

aA "<" indicates that the maximum concentration was below detection limits (number shown is,detection limit). A " $"$ indicates an approximate value (the value was outside the limits for which the instrument was calibrated)

balkalinity

CThe values listed multiplied by $10^{-9}$ will result in $\mu \mathrm{Ci} / \mathrm{mL}$

dConductivity

eMicromhos per cent imeter 
Iable A 19 (econtinued) Water (hemistry Data for Grand Junction, March 16 through March 18, 1992a

\begin{tabular}{|c|c|c|c|c|c|c|c|c|c|c|c|}
\hline $\begin{array}{l}\text { Sapple } \\
\text { location }\end{array}$ & $\begin{array}{l}\text { Itcket } \\
\text { mudier }\end{array}$ & $\begin{array}{l}\text { Simple } \\
\text { Date }\end{array}$ & $\begin{array}{c}\text { fe } \\
(\mu g / l)\end{array}$ & $\begin{array}{l}\mathrm{H}_{2} \mathrm{O} \text { Depth } \\
\text { (f eet) }\end{array}$ & $\begin{array}{l}\text { Herbicide } \\
\text { ( } \mu \mathrm{g} / \mathrm{L})\end{array}$ & $\underset{(\mu g / L)}{K}$ & $\underset{(\mu g / L)}{M g}$ & $\operatorname{mn}_{(\mu g / L)}$ & $\underset{(\mu \mathrm{g} / \mathrm{L})}{\boldsymbol{M}_{0}}$ & $\underset{(\mu g / L)}{\mathrm{Ma}}$ & $\underset{(\mu g / L)}{\mathrm{NO}_{3}}$ \\
\hline \multicolumn{12}{|l|}{ Ground Water } \\
\hline $\begin{array}{l}1.9 S A \\
10-19 N \\
11-15 \\
13-16 N A \\
13-16 N A \text { (Dup) } \\
14-13 N A \\
14-6 N A \\
3-3 N A \\
5-12 N A \\
\text { GJ84 04 } \\
\text { GJ84 05 } \\
\text { GJ84-06 } \\
\text { GJ84-09 } \\
\text { GJ84-10 } \\
\text { P-2A } \\
\text { P-3A } \\
\text { P-4A } \\
\text { P-6 }\end{array}$ & 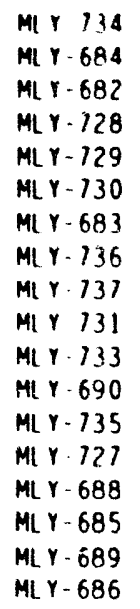 & $\begin{array}{l}03 / 18 / 1992 \\
03 / 17 / 1992 \\
03 / 17 / 1992 \\
03 / 17 / 1992 \\
03 / 17 / 1992 \\
03 / 17 / 1992 \\
03 / 17 / 1992 \\
03 / 18 / 1992 \\
03 / 18 / 1992 \\
03 / 17 / 1992 \\
03 / 17 / 1992 \\
03 / 18 / 1992 \\
03 / 18 / 1992 \\
03 / 16 / 1992 \\
03 / 18 / 1992 \\
03 / 17 / 1992 \\
03 / 18 / 1992 \\
03 / 18 / 1992\end{array}$ & $\begin{array}{l}-24.8 \\
427 \\
<10.0 \\
<10.0 \\
<10.0 \\
<10.0 \\
1930 \\
632 \\
<10.0 \\
-11.2 \\
-40.9 \\
<10.0 \\
-28.3 \\
<10.0 \\
<10.0 \\
<10.0 \\
246 \\
<10.0\end{array}$ & $\begin{array}{r}13.45 \\
12.91 \\
16.22 \\
4.48 \\
\text { No Data } \\
6.25 \\
17.47 \\
12.31 \\
9.88 \\
9.08 \\
11.31 \\
13.89 \\
20.90 \\
32.03 \\
15.71 \\
4.21 \\
9.77 \\
12.10\end{array}$ & $\begin{array}{l}\text { No Detect } \\
\text { No Detect } \\
\text { No Detect } \\
\text { No Detect } \\
\text { No Detect } \\
\text { No Detect } \\
\text { No Detect } \\
\text { No Detect } \\
\text { No Detect } \\
\text { No Detect } \\
\text { No Detect } \\
\text { No Detect } \\
\text { No Detect } \\
\text { No Detect } \\
\text { No Detect } \\
\text { No Detect } \\
\text { No Detect } \\
\text { No Detect }\end{array}$ & $\begin{array}{r}6010 \\
20900 \\
9860 \\
16100 \\
15100 \\
14800 \\
18900 \\
17400 \\
5670 \\
11900 \\
17800 \\
5110 \\
7710 \\
5530 \\
11700 \\
10100 \\
23900 \\
6040\end{array}$ & $\begin{array}{r}17400 \\
301000 \\
95700 \\
94800 \\
93100 \\
58800 \\
28500 \\
142000 \\
114000 \\
61100 \\
192000 \\
122000 \\
20600 \\
31100 \\
88300 \\
60900 \\
276000 \\
16300\end{array}$ & $\begin{array}{c}652 \\
4880 \\
92.7 \\
6660 \\
6620 \\
3000 \\
4630 \\
4710 \\
482 \\
2800 \\
4570 \\
77.5 \\
178 \\
542 \\
2550 \\
5540 \\
3170 \\
575\end{array}$ & $\begin{array}{l}<21.0 \\
206 \\
270 \\
155 \\
149 \\
155 \\
<21.0 \\
<21.0 \\
<21.0 \\
304 \\
172 \\
<21.0 \\
<21.0 \\
<21.0 \\
<21.0 \\
156 \\
89.9 \\
<21.0\end{array}$ & $\begin{array}{r}323000 \\
1720000 \\
655000 \\
611000 \\
616000 \\
377000 \\
135000 \\
974000 \\
327000 \\
730000 \\
1430000 \\
232000 \\
370000 \\
507000 \\
555000 \\
335000 \\
1160000 \\
339000\end{array}$ & $\begin{array}{c}-90.6 \\
-60.4 \\
71800 \\
1600 \\
1600 \\
5850 \\
204 \\
-169 \\
1280 \\
-140 \\
\sim 99.1 \\
1510 \\
907 \\
-128 \\
23600 \\
\sim 62.6 \\
543 \\
2610\end{array}$ \\
\hline \multicolumn{12}{|l|}{ Surface Water } \\
\hline $\begin{array}{l}\text { Lower Gunnison } \\
\text { Middle Gunnison } \\
\text { North Pond } \\
\text { South Pond } \\
\text { Upper Gunnison } \\
\text { Upper Mid Gunnison }\end{array}$ & $\begin{array}{l}M L Y-726 \\
M L Y-677 \\
M L Y-679 \\
M L Y-680 \\
M L Y-678 \\
M L Y-681\end{array}$ & $\begin{array}{l}03 / 16 / 1992 \\
03 / 16 / 1992 \\
03 / 16 / 1992 \\
03 / 16 / 1932 \\
03 / 16 / 1992 \\
03 / 16 / 1992\end{array}$ & $\begin{array}{l}<10.0 \\
<10.0 \\
<10.0 \\
<10.0 \\
<10.0 \\
<10.0\end{array}$ & $\begin{array}{l}\text { No Data } \\
\text { No Data } \\
\text { No Data } \\
\text { No Data } \\
\text { No Data } \\
\text { No Data }\end{array}$ & $\begin{array}{l}\text { No Data } \\
\text { No Data } \\
\text { No Data } \\
\text { No Data } \\
\text { No Data } \\
\text { No Data }\end{array}$ & $\begin{array}{l}-2320 \\
-2570 \\
16600 \\
16700 \\
-2250 \\
-2430\end{array}$ & $\begin{array}{r}37800 \\
35500 \\
142000 \\
78400 \\
35600 \\
36500\end{array}$ & $\begin{array}{c}85.0 \\
49.4 \\
287 \\
500 \\
60.3 \\
46.7\end{array}$ & $\begin{array}{l}<21.0 \\
<21.0 \\
\sim 39.9 \\
207 \\
<21.0 \\
<21.0\end{array}$ & $\begin{array}{r}71300 \\
59900 \\
674000 \\
371000 \\
59800 \\
60100\end{array}$ & $\begin{array}{r}2510 \\
2500 \\
\sim 246 \\
10800 \\
2640 \\
2410\end{array}$ \\
\hline \multicolumn{12}{|l|}{$Q A / Q C$} \\
\hline $\begin{array}{l}\text { Equipment Blank } \\
\text { Trip Blank } \\
\text { Trip Blank }\end{array}$ & $\begin{array}{l}\text { MLY Y } 732 \\
\text { MLY }-676 \\
\text { MLY }-687\end{array}$ & $\begin{array}{l}03 / 17 / 1992 \\
03 / 16 / 1992 \\
03 / 18 / 1992\end{array}$ & $\begin{array}{l}<10.0 \\
\text { No Data } \\
\text { No Data }\end{array}$ & $\begin{array}{l}\text { No Data } \\
\text { No Data } \\
\text { No Data }\end{array}$ & $\begin{array}{l}\text { No Detect } \\
\text { No Data } \\
\text { No Data }\end{array}$ & $\begin{array}{l}<1300 \\
\text { No Data } \\
\text { No Data }\end{array}$ & $\begin{array}{l}<86.0 \\
\text { No Data } \\
\text { No Data }\end{array}$ & $\begin{array}{l}<1.0 \\
\text { No Data } \\
\text { No Data }\end{array}$ & $\begin{array}{l}<21.0 \\
\text { No Data } \\
\text { No Data }\end{array}$ & $\begin{array}{l}-115 \\
\text { No Data } \\
\text { No Data }\end{array}$ & $\begin{array}{l}-23.9 \\
\text { No Data } \\
\text { No Data }\end{array}$ \\
\hline
\end{tabular}

$a_{A}$ "<" indicates that the maximum concentration was below detection limits (number shown is detection 1 imit). A " " indicates an approximate value (the value was outside the 1 imits for which the instrument was calibrated). "No Detect" indicates that the maximum concentration was below detection limits (detection limits are listed in Table A-21). 
Table A-18 (continued). Water Chemistry Data for Grand Junction, March 16 through March 18, 1992a

\begin{tabular}{|c|c|c|c|c|c|c|c|c|c|c|c|}
\hline $\begin{array}{l}\text { Sample } \\
\text { Location }\end{array}$ & $\begin{array}{l}\text { Ticket } \\
\text { Number }\end{array}$ & $\begin{array}{l}\text { Sample } \\
\text { Date }\end{array}$ & $\underset{(\mu g / L)}{P b}$ & $\begin{array}{l}\text { Pesticide } \\
\text { ( } \mu \mathrm{g} / \mathrm{L})\end{array}$ & pH & $\begin{array}{c}R a-226 \\
(p C i / L)^{b}\end{array}$ & $\begin{array}{c}\mathrm{Ra}-228 \\
(\mathrm{pCi} / \mathrm{L})^{\mathrm{b}}\end{array}$ & $\begin{array}{c}S e \\
(\mu / L)\end{array}$ & $\begin{array}{c}\text { Semivolatile } \\
(\mu g / L)\end{array}$ & e $\underset{(\mu g / L)}{\mathrm{SO}_{4}}$ & $\begin{array}{l}\text { TDS } \\
(\operatorname{mg} / \mathrm{L})\end{array}$ \\
\hline \multicolumn{12}{|l|}{ Ground Mater } \\
\hline $\begin{array}{l}1-9 S A \\
10-19 N \\
11-1 S \\
13-16 N A \\
13-16 N A \text { (Dup) } \\
14-13 N A \\
14-6 N A \\
3-3 N A \\
5-12 N A \\
\text { GJ84-04 } \\
\text { GJ84-05 } \\
\text { GJ84-06 } \\
\text { GJ84-09 } \\
\text { GJ84-10 } \\
\text { P-2A } \\
P-3 A \\
P-4 A \\
P-6\end{array}$ &  & $\begin{array}{l}03 / 18 / 1992 \\
03 / 17 / 1992 \\
03 / 17 / 1992 \\
03 / 17 / 1092 \\
03 / 17 / 1992 \\
03 / 17 / 1992 \\
03 / 17 / 1992 \\
03 / 18 / 1992 \\
03 / 18 / 1992 \\
03 / 17 / 1992 \\
03 / 17 / 1992 \\
03 / 18 / 1992 \\
03 / 18 / 1992 \\
03 / 16 / 1992 \\
03 / 18 / 1992 \\
03 / 17 / 1992 \\
03 / 18 / 1992 \\
03 / 18 / 1992\end{array}$ & $\begin{array}{l}<1.0 \\
<1.0 \\
<1.0 \\
<1.0 \\
<1.0 \\
<1.0 \\
<1.0 \\
<1.0 \\
<1.0 \\
<1.0 \\
<1.0 \\
<1.5 \\
<1.0 \\
<1.0 \\
<1.0 \\
<1.0 \\
<1.0 \\
<1.0\end{array}$ & $\begin{array}{l}\text { No Detect } \\
\text { No Detect } \\
\text { No Detect } \\
\text { No Detect } \\
\text { No Detect } \\
\text { No Detect } \\
\text { No Detect } \\
\text { No Detect } \\
\text { No Detect } \\
\text { No Detect } \\
\text { No Detect } \\
\text { No Detect } \\
\text { No Detect } \\
\text { No Detect } \\
\text { No Detect } \\
\text { No Detect } \\
\text { No Detect } \\
\text { No Detect }\end{array}$ & $\begin{array}{r}7.91 \\
7.18 \\
7.10 \\
6.87 \\
\text { No Data } \\
7.23 \\
7.20 \\
7.47 \\
7.36 \\
7.41 \\
7.25 \\
7.10 \\
7.50 \\
7.45 \\
7.19 \\
6.75 \\
6.96 \\
7.29\end{array}$ & $\begin{array}{l}<0.4 \\
<0.4 \\
<0.4 \\
<0.4 \\
<0.4 \\
<0.4 \\
<0.4 \\
<0.4 \\
<0.4 \\
<0.4 \\
<0.4 \\
<0.4 \\
<0.4 \\
<0.4 \\
<0.4 \\
<0.4 \\
<0.4 \\
<0.4\end{array}$ & $\begin{array}{l}<1 \\
<1 \\
<1 \\
<1 \\
<1 \\
<1 \\
<1 \\
<1 \\
<1 \\
<1 \\
<1 \\
<1 \\
<1 \\
<1 \\
<1 \\
<1 \\
<1 \\
<1\end{array}$ & $\begin{array}{r}<2.0 \\
<20.0 \\
48.5 \\
25.4 \\
14.8 \\
38.9 \\
<2.0 \\
<20.0 \\
<20.0 \\
<2.0 \\
<20.0 \\
\sim 2.4 \\
<2.0 \\
<2.0 \\
80.5 \\
<20.0 \\
<20.0 \\
\sim 4.0\end{array}$ & $\begin{array}{l}\text { See Table } \\
\text { See Table } 4 \\
\text { See Table } 1 \\
\text { No Detect } 1 \\
\text { See Table } 1 \\
\text { See Table } 1 \\
\text { See Table } \\
\text { See Table } 2 \\
\text { See Table } 1 \\
\text { No Detect } 1 \\
\text { No Detect } 3 \\
\text { No Detect } 1 \\
\text { No Detect } \\
\text { See Table } 1 \\
\text { No Detect } 1 \\
\text { No Detect } 1 \\
\text { See Table } 3 \\
\text { No Detect }\end{array}$ & $\begin{array}{r}733000 \\
4510000 \\
1420000 \\
1750000 \\
1750000 \\
1140000 \\
468000 \\
2790000 \\
1360000 \\
1760000 \\
3750000 \\
1430000 \\
541000 \\
1150000 \\
1690000 \\
1210000 \\
3520000 \\
671000\end{array}$ & $\begin{array}{l}1440 \\
8380 \\
2820 \\
3540 \\
3540 \\
2380 \\
1040 \\
6420 \\
2800 \\
3320 \\
6960 \\
2840 \\
1840 \\
2180 \\
3300 \\
2360 \\
6580 \\
1380\end{array}$ \\
\hline \multicolumn{12}{|l|}{ Surface Water } \\
\hline $\begin{array}{l}\text { Lower Gunnison } \\
\text { Middle Gunnison } \\
\text { North Pond } \\
\text { South Pnnd } \\
\text { Upper Gunnison } \\
\text { Upper Mid Gunnison }\end{array}$ & $\begin{array}{l}\text { MLY } Y-726 \\
\text { MLY }-677 \\
\text { MLY-679 } \\
\text { MLY }-680 \\
\text { MLY }-678 \\
\text { MLY }-681\end{array}$ & $\begin{array}{l}03 / 16 / 1992 \\
03 / 16 / 1992 \\
03 / 16 / 1992 \\
03 / 16 / 1992 \\
03 / 16 / 1992 \\
03 / 16 / 1992\end{array}$ & $\begin{array}{l}<1.0 \\
<1.0 \\
<1.0 \\
<1.0 \\
<1.0 \\
<1.0\end{array}$ & $\begin{array}{l}\text { No Data } \\
\text { No Data } \\
\text { No Data } \\
\text { No Data } \\
\text { No Data } \\
\text { No Data }\end{array}$ & $\begin{array}{l}8.31 \\
8.34 \\
8.11 \\
8.87 \\
8.22 \\
8.55\end{array}$ & $\begin{array}{l}<0.4 \\
<0.4 \\
<0.4 \\
<0.4 \\
<0.4 \\
<0.4\end{array}$ & $\begin{array}{l}<1 \\
<1 \\
<1 \\
<1 \\
<1 \\
<1\end{array}$ & $\begin{array}{r}-3.8 \\
7.0 \\
<2.0 \\
16.4 \\
-2.5 \\
-3.8\end{array}$ & $\begin{array}{l}\text { No Data } \\
\text { No Data } \\
\text { No Data } 19 \\
\text { No Data } 14 \\
\text { No Data } \\
\text { No Data }\end{array}$ & $\begin{array}{r}343000 \\
311000 \\
1980000 \\
1410000 \\
310000 \\
314000\end{array}$ & $\begin{array}{r}760 \\
700 \\
3940 \\
2520 \\
700 \\
640\end{array}$ \\
\hline \multicolumn{12}{|l|}{$Q A / Q C$} \\
\hline $\begin{array}{l}\text { Equipment Blank } \\
\text { Trip Blank } \\
\text { Trip Blank }\end{array}$ & $\begin{array}{l}\text { MLY Y-732 } \\
\text { MLY }-676 \\
\text { MLY-687 }\end{array}$ & $\begin{array}{l}03 / 17 / 1992 \\
03 / 16 / 1992 \\
03 / 18 / 1992\end{array}$ & $\begin{array}{l}\text { <1.0 } \\
\text { No Data } \\
\text { No Data }\end{array}$ & $\begin{array}{l}\text { No Detect } \\
\text { No Data } \\
\text { No Data }\end{array}$ & $\begin{array}{l}\text { No Data } \\
\text { No Data } \\
\text { No Data }\end{array}$ & $\begin{array}{l}\quad<0.4 \\
\text { No Data } \\
\text { No Data }\end{array}$ & $\begin{array}{l}<1 \\
\text { No Data } \\
\text { No Data }\end{array}$ & $\begin{array}{l}\quad<2.0 \\
\text { No Data } \\
\text { No Data }\end{array}$ & $\begin{array}{l}\text { See Table } \\
\text { No Data } \\
\text { No Data }\end{array}$ & $\begin{array}{l}-95.4 \\
\text { No Data } \\
\text { No Data }\end{array}$ & $\begin{array}{l}<20 \\
\text { No Data } \\
\text { Mo Data }\end{array}$ \\
\hline
\end{tabular}

a "<" indicates that the maximum concentration was below detection limits (number shown is detection 1 imit). A " $\sim$ indicates an approximate value (the value was outside the limits for which the instrument was calibrated). "Ko Detect" indicates that the maximum concentration was below detection limits (detection 1 imits are listed in Table A-21); "See Table" indicates that the reader should refer to Table A-23 in this report for a list of detected constituents.

bThe values $l i$ isted multiplied by $10^{-9}$ will result in $\mu \mathrm{C} i / \mathrm{mL}$. 
Table A-18 (continued). Water Chemistry Data for Grand Junction, March 16 through March 18, $1992^{a}$

\begin{tabular}{|c|c|c|c|c|c|c|c|c|c|}
\hline $\begin{array}{c}\text { Sample } \\
\text { Location }\end{array}$ & $\begin{array}{l}\text { Ticket } \\
\text { Number }\end{array}$ & $\begin{array}{l}\text { Sample } \\
\text { Date }\end{array}$ & $\begin{array}{c}\text { Temp } \\
(\operatorname{Deg} C)\end{array}$ & $\begin{array}{c}\text { Th-230 } \\
(\mathrm{pCi} / \mathrm{L})^{\mathrm{b}}\end{array}$ & $\begin{array}{c}\text { TOC } \\
(m g / L)\end{array}$ & $\underset{(\mathrm{pCi} / L)^{\mathrm{b}}}{\mathrm{U}-234}$ & $\begin{array}{c}U-238 \\
(\mathrm{pCi} / L)^{b}\end{array}$ & $\underset{(\mu g / L)}{V}$ & $\begin{array}{l}\text { Volatile } \\
(\mu g / L)\end{array}$ \\
\hline \multicolumn{10}{|l|}{ Ground Water } \\
\hline $\begin{array}{l}1-9 S A \\
10-19 N \\
11-1 S \\
13-16 N A \\
13-16 N A \text { (Dup) } \\
14-13 N A \\
14-6 N A \\
3-3 N A \\
5-12 N A \\
\text { GJ84-04 } \\
\text { GJ84-05 } \\
\text { GJ84-06 } \\
\text { GJ84-09 } \\
\text { GJ84-10 } \\
\text { P-2A } \\
\text { P-3A } \\
\text { P-4A } \\
\text { P-6 }\end{array}$ & 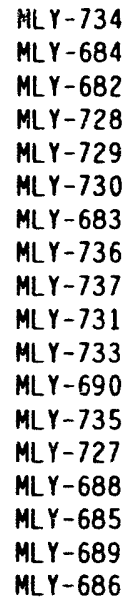 & $\begin{array}{l}03 / 18 / 1992 \\
03 / 17 / 1992 \\
03 / 17 / 1992 \\
03 / 17 / 1992 \\
03 / 17 / 1992 \\
03 / 17 / 1992 \\
03 / 17 / 1992 \\
03 / 18 / 1992 \\
03 / 18 / 1992 \\
03 / 17 / 1992 \\
03 / 17 / 1992 \\
03 / 18 / 1992 \\
03 / 18 / 1992 \\
03 / 16 / 1992 \\
03 / 18 / 1992 \\
03 / 17 / 1992 \\
03 / 18 / 1992 \\
03 / 18 / 1992\end{array}$ & $\begin{array}{c}14.3 \\
9.7 \\
13.4 \\
11.2 \\
\text { No Data } \\
12.2 \\
12.3 \\
15.7 \\
13.5 \\
12.3 \\
11.2 \\
14.8 \\
14.9 \\
16.3 \\
15.9 \\
11.3 \\
12.7 \\
12.9\end{array}$ & $\begin{array}{l}<0.3 \\
<0.3 \\
<0.3 \\
<0.3 \\
<0.3 \\
<0.3 \\
<0.3 \\
<0.3 \\
<0.3 \\
<0.3 \\
<0.3 \\
<0.3 \\
<0.3 \\
<0.3 \\
<0.3 \\
<0.3 \\
<0.3 \\
<0.3\end{array}$ & $\begin{array}{r}3.7 \\
19.3 \\
7.3 \\
11.1 \\
12.1 \\
5.5 \\
6.2 \\
3.1 \\
5.0 \\
7.0 \\
13.9 \\
6.3 \\
2.0 \\
3.9 \\
8.3 \\
8.6 \\
31.9 \\
5.1\end{array}$ & $\begin{array}{r}11.2 \\
243.8 \\
288.4 \\
46.0 \\
89.4 \\
207.7 \\
32.6 \\
51.0 \\
25.5 \\
178.0 \\
498.8 \\
18.5 \\
8.1 \\
8.8 \\
16.3 \\
329.4 \\
168.9 \\
14.5\end{array}$ & $\begin{array}{r}7.2 \\
246.0 \\
285.7 \\
58.1 \\
109.4 \\
197.7 \\
33.5 \\
30.4 \\
16.3 \\
205.8 \\
496.8 \\
11.7 \\
4.7 \\
5.7 \\
12.7 \\
317.8 \\
156.3 \\
10.1\end{array}$ & $\begin{array}{r}<7.0 \\
<7.0 \\
<7.0 \\
\sim 17.1 \\
<19.4 \\
\sim 18.7 \\
<7.0 \\
<7.0 \\
<7.0 \\
\sim 29.6 \\
<7.0 \\
<7.0 \\
<7.0 \\
<7.0 \\
<7.0 \\
<7.0 \\
<7.0 \\
<7.0\end{array}$ & $\begin{array}{l}\text { No Detect } \\
\text { See Table } \\
\text { See Table } \\
\text { No Detect } \\
\text { See Table } \\
\text { See Table } \\
\text { See Table } \\
\text { No Detect } \\
\text { See Table } \\
\text { No Detect } \\
\text { See Table } \\
\text { See Table } \\
\text { No Detect } \\
\text { No Detect } \\
\text { See Table } \\
\text { See Table } \\
\text { See Table } \\
\text { No Detect }\end{array}$ \\
\hline \multicolumn{10}{|l|}{ Surface Uater } \\
\hline $\begin{array}{l}\text { Lower Gunnison } \\
\text { Middle Gunnison } \\
\text { North Pond } \\
\text { South Pond } \\
\text { Upper Gunnison } \\
\text { Upper Mid Gunnison }\end{array}$ & $\begin{array}{l}\text { MLY Y }-726 \\
\text { MLY }-677 \\
\text { MLY }-679 \\
\text { MLY }-680 \\
\text { MLY }-678 \\
\text { MLY }-681\end{array}$ & $\begin{array}{l}03 / 16 / 1992 \\
03 / 16 / 1992 \\
03 / 16 / 1992 \\
03 / 16 / 1992 \\
03 / 16 / 1992 \\
03 / 16 / 1992\end{array}$ & $\begin{array}{r}10.2 \\
9.7 \\
16.3 \\
16.1 \\
11.1 \\
13.7\end{array}$ & $\begin{array}{l}<0.3 \\
<0.3 \\
<0.3 \\
<0.3 \\
<0.3 \\
<0.3\end{array}$ & $\begin{array}{r}6.2 \\
4.9 \\
18.3 \\
77.2 \\
6.8 \\
11.8\end{array}$ & $\begin{array}{r}6.8 \\
4.4 \\
194.0 \\
210.1 \\
4.7 \\
4.1\end{array}$ & $\begin{array}{r}5.2 \\
2.6 \\
169.5 \\
208.3 \\
2.6 \\
2.9\end{array}$ & $\begin{array}{r}<7.0 \\
<7.0 \\
<7.0 \\
-40.6 \\
<7.0 \\
<7.0\end{array}$ & $\begin{array}{l}\text { No Data } \\
\text { No Data } \\
\text { No Data } \\
\text { No Data } \\
\text { No Data } \\
\text { No Data }\end{array}$ \\
\hline \multicolumn{10}{|l|}{ QA/QC } \\
\hline $\begin{array}{l}\text { Equipment Blank } \\
\text { Trip Blank } \\
\text { Trip Blank }\end{array}$ & $\begin{array}{l}\text { MLY Y }-732 \\
\text { MLY }-676 \\
\text { MLY }-687\end{array}$ & $\begin{array}{l}03 / 17 / 1992 \\
03 / 16 / 1992 \\
03 / 18 / 1992\end{array}$ & $\begin{array}{l}\text { No Data } \\
\text { No Data } \\
\text { No Data }\end{array}$ & $\begin{array}{c}<0.3 \\
\text { No Data } \\
\text { No Data }\end{array}$ & $\begin{array}{c}0.7 \\
\text { No Data } \\
\text { No Data }\end{array}$ & 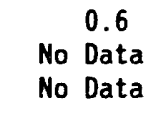 & $\begin{array}{l}0.6 \\
\text { No Data } \\
\text { No Data }\end{array}$ & $\begin{array}{l}<7.0 \\
\text { No Data } \\
\text { No Data }\end{array}$ & $\begin{array}{l}\text { No Detect } \\
\text { See Table } \\
\text { See Table }\end{array}$ \\
\hline
\end{tabular}

$a_{A} "<"$ indicates that the maximum concentration was below detection limits (number shown is $\therefore$ ection 1 imit) A " " indicates an approximate value (the value was outside the limits for which the instrument vas calibrated);

"See Table" indicates that the reader should refer to Table A-23 in this report for a 1 ist of detected constituents.

bThe values listed multiplied by $10^{-9}$ will result in $\mu \mathrm{Ci} / \mathrm{mL}$. 
Table A-19. Water Chemistry Data for Grand Junction, June 15 through June 19, 1992a

\begin{tabular}{|c|c|c|c|c|c|c|c|c|c|c|c|}
\hline $\begin{array}{l}\text { Sample } \\
\text { Location }\end{array}$ & $\begin{array}{l}\text { Ticket } \\
\text { Number }\end{array}$ & $\begin{array}{l}\text { Sample } \\
\text { Date }\end{array}$ & $\begin{array}{c}\text { Alky } \\
(\mathrm{ppm}) \\
\left(\mathrm{as} \mathrm{CaCO}_{3}\right)\end{array}$ & $\begin{array}{l}\text { Alpha } \\
(\mathrm{pCi} / \mathrm{L})^{\mathrm{b}}\end{array}$ & $\begin{array}{l}\text { As } \\
(\mu g / L)\end{array}$ & $\underset{(\mu \mathrm{g} / \mathrm{L})}{\mathrm{Ba}}$ & $\underset{(\mu \mathrm{ga} / \mathrm{L})}{\mathrm{Ca}}$ & $\underset{(\mu g / L)}{C d}$ & $\underset{(p \operatorname{hos} / \mathrm{cm})}{\text { CDT }}$ & $\stackrel{C 1}{(\mu g / L)}$ & $\underset{(\mu g / L)}{C r}$ \\
\hline \multicolumn{12}{|l|}{ Ground Vater } \\
\hline $\begin{array}{l}1-9 S A \\
10-19 N \\
11-12 N A \\
13-16 N A \\
14-13 N A \\
14-6 N A \\
5-12 N A \\
\text { GJ84-04 } \\
\text { GJ84-09 } \\
\text { GJ84-10 } \\
\text { GJ87-15 } \\
\text { GJ87-15 (Dup) }\end{array}$ & $\begin{array}{l}\text { MLY Y-846 } \\
\text { MLY-844 } \\
\text { MLY-843 } \\
\text { MLY-840 } \\
\text { MLY-841 } \\
\text { MLY-845 } \\
\text { MLY Y-837 } \\
\text { MLY-842 } \\
\text { MLY-836 } \\
\text { MLY-834 } \\
\text { MLY-838 } \\
\text { MLY-839 }\end{array}$ & $\begin{array}{l}06 / 19 / 1992 \\
06 / 18 / 1992 \\
06 / 18 / 1992 \\
06 / 18 / 1992 \\
06 / 18 / 1992 \\
06 / 19 / 1992 \\
06 / 17 / 1992 \\
06 / 18 / 1992 \\
06 / 17 / 1992 \\
06 / 16 / 1992 \\
06 / 17 / 1992 \\
06 / 17 / 1992\end{array}$ & $\begin{array}{l}232 \\
702 \\
370 \\
480 \\
306 \\
199 \\
329 \\
287 \\
247 \\
248 \\
326 \\
\text { No Data }\end{array}$ & $\begin{array}{r}<60 \\
1200 \\
290 \\
1300 \\
720 \\
60 \\
100 \\
570 \\
<70 \\
<75 \\
440 \\
400\end{array}$ & $\begin{array}{l}<3.0 \\
<3.0 \\
36.0 \\
\sim 3.3 \\
\sim 8.1 \\
203 \\
<3.0 \\
16.1 \\
\sim 3.0 \\
<3.0 \\
109 \\
111\end{array}$ & $\begin{array}{r}\sim 9.6 \\
\sim 10.6 \\
\sim 15.0 \\
-16.7 \\
-14.0 \\
\sim 38.5 \\
\sim 10.1 \\
\sim 12.7 \\
-10.1 \\
\sim 7.0 \\
-17.3 \\
-15.3\end{array}$ & $\begin{array}{r}99100 \\
465000 \\
285000 \\
477000 \\
290000 \\
92900 \\
290000 \\
149000 \\
124000 \\
133000 \\
248000 \\
249000\end{array}$ & $\begin{array}{l}<1.0 \\
<1.0 \\
<1.0 \\
<1.0 \\
<1.0 \\
<1.0 \\
<1.0 \\
<1.0 \\
<1.0 \\
<1.0 \\
<1.0 \\
<1.0\end{array}$ & $\begin{array}{l}1950 \\
8130 \\
3350 \\
5460 \\
3450 \\
1070 \\
3140 \\
3580 \\
2390 \\
2690 \\
2900 \\
\text { No Data }\end{array}$ & $\begin{array}{r}10700 \\
521000 \\
160000 \\
300000 \\
150000 \\
20200 \\
152000 \\
102000 \\
45100 \\
97500 \\
139000 \\
140000\end{array}$ & $\begin{array}{l}<4.0 \\
<4.0 \\
<4.0 \\
<4.0 \\
<4.0 \\
<4.0 \\
<4.0 \\
<4.0 \\
<4.0 \\
<4.0 \\
<4.0 \\
<4.0\end{array}$ \\
\hline \multicolumn{12}{|l|}{ Surface Vater } \\
\hline $\begin{array}{l}\text { Lower Gunnison } \\
\text { Middle Gunnison } \\
\text { North Pond } \\
\text { South Pond } \\
\text { Upper Gunnison } \\
\text { Upper Mid Gunnison }\end{array}$ & $\begin{array}{l}M L Y-829 \\
M L Y-828 \\
M L Y-831 \\
M L Y-833 \\
M L Y-826 \\
M L Y-827\end{array}$ & $\begin{array}{l}06 / 15 / 1992 \\
06 / 15 / 1992 \\
06 / 16 / 1992 \\
06 / 16 / 1992 \\
06 / 15 / 1992 \\
06 / 15 / 1992\end{array}$ & $\begin{array}{r}99 \\
103 \\
130 \\
80 \\
102 \\
94\end{array}$ & $\begin{array}{l}<20 \\
<20 \\
399 \\
324 \\
<30 \\
<30\end{array}$ & $\begin{array}{l}<3.0 \\
-3.5 \\
-5.1 \\
22.1 \\
\sim 3.4 \\
<3.0\end{array}$ & $\begin{array}{l}\sim 32.0 \\
-33.9 \\
-17.6 \\
\sim 25.9 \\
\sim 34.4 \\
\sim 36.5\end{array}$ & $\begin{array}{r}79000 \\
81100 \\
283000 \\
321000 \\
83000 \\
80900\end{array}$ & $\begin{array}{l}<1.0 \\
<1.0 \\
<1.0 \\
<1.0 \\
<1.0 \\
<1.0\end{array}$ & $\begin{array}{r}699 \\
699 \\
4630 \\
3290 \\
730 \\
711\end{array}$ & $\begin{array}{r}5000 \\
5110 \\
303000 \\
168000 \\
5370 \\
5320\end{array}$ & $\begin{array}{l}<4.0 \\
<4.0 \\
<4.0 \\
<4.0 \\
<4.0 \\
<4.0\end{array}$ \\
\hline \multicolumn{12}{|l|}{$Q A / Q C$} \\
\hline $\begin{array}{l}\text { Equipment Blank } \\
\text { Trip Blank } \\
\text { Trip Blank }\end{array}$ & $\begin{array}{l}\text { MLY } Y-832 \\
\text { MLY } 830 \\
\text { MLY }-835\end{array}$ & $\begin{array}{l}06 / 16 / 1992 \\
06 / 16 / 1992 \\
06 / 17 / 1992\end{array}$ & $\begin{array}{l}\text { No Data } \\
\text { No Data } \\
\text { No Data }\end{array}$ & $\begin{array}{l}<7 \\
\text { No Data } \\
\text { No Data }\end{array}$ & $\begin{array}{l}\quad 3.0 \\
\text { No Data } \\
\text { No Data }\end{array}$ & $\begin{array}{l}<4.0 \\
\text { No Data } \\
\text { No Data }\end{array}$ & $\begin{array}{l}319000 \\
\text { No Data } \\
\text { No Data }\end{array}$ & $\begin{array}{l}<1.0 \\
\text { No Data } \\
\text { No Data }\end{array}$ & $\begin{array}{l}\text { No Data } \\
\text { No Data } \\
\text { No Data }\end{array}$ & $\begin{array}{l}\sim 114 \\
\text { No Data } \\
\text { No Data }\end{array}$ & $\begin{array}{l}<4.0 \\
\text { Mo Data } \\
\text { No Data }\end{array}$ \\
\hline
\end{tabular}

$a_{A} "<"$ indicates that the maximum concentration was below detection limits (number shown is detection 1 imit). A " $"$ indicates an approximate value (the value was outside the limits for which the instrument was calibrated).

bThe values 1 isted multiplied by $10^{-9}$ will result in $\mu \mathrm{Ci} / \mathrm{mL}$. 
Table A-19 (continued). Water Chemistry Data for Grand Junction, June 15 through June 19, 1992a

\begin{tabular}{|c|c|c|c|c|c|c|c|c|c|c|c|}
\hline $\begin{array}{l}\text { Sample } \\
\text { Location }\end{array}$ & $\begin{array}{l}\text { Ticket } \\
\text { Number }\end{array}$ & $\begin{array}{l}\text { Sample } \\
\text { Date }\end{array}$ & $\underset{(\mu \mathrm{ge} / \mathrm{L})}{\mathrm{Fe}}$ & $\begin{array}{l}\mathrm{H}_{2} \mathrm{O} \text { Depth } \\
\text { (f eet) }\end{array}$ & $\begin{array}{r}\text { Herb } \\
(\mu g / L)\end{array}$ & $\underset{(\mu g / L)}{K}$ & $\underset{(\mu g / L)}{\mathrm{Mg}}$ & $\operatorname{mn}_{(\mu g / L)}$ & $\begin{array}{c}M o \\
(\mu g / L)\end{array}$ & $\underset{(\mu g / L)}{\mathrm{Na}}$ & $\underset{(\mu g / L)}{N_{3}}$ \\
\hline \multicolumn{12}{|l|}{ Ground Water } \\
\hline $\begin{array}{l}1-9 S A \\
10-19 N \\
11-12 N A \\
13-16 N A \\
14-13 N A \\
14-6 N A \\
5-12 N A \\
\text { GJ84-04 } \\
\text { GJ84-09 } \\
\text { GJ84-10 } \\
\text { GJ87-15 } \\
\text { GJ87-15 (Dup) }\end{array}$ & $\begin{array}{l}\text { MLY } Y-846 \\
M L Y-844 \\
M L Y-843 \\
M L Y-840 \\
M L Y-841 \\
\text { MLY-845 } \\
\text { MLY-837 } \\
\text { MLY-842 } \\
\text { MLY-836 } \\
\text { MLY-834 } \\
\text { MLY-838 } \\
\text { MLY-839 }\end{array}$ & $\begin{array}{l}06 / 19 / 1992 \\
06 / 18 / 1992 \\
06 / 18 / 1992 \\
06 / 18 / 1992 \\
06 / 18 / 1992 \\
06 / 19 / 1992 \\
06 / 17 / 1992 \\
06 / 18 / 1992 \\
06 / 17 / 1992 \\
06 / 16 / 1992 \\
06 / 17 / 1992 \\
06 / 17 / 1992\end{array}$ & $\begin{array}{c}<9.0 \\
216 \\
<9.0 \\
249 \\
<9.0 \\
1030 \\
<9.0 \\
<9.0 \\
121 \\
<9.0 \\
<9.0 \\
<9.0\end{array}$ & $\begin{array}{r}11.18 \\
11.70 \\
4.78 \\
3.37 \\
4.70 \\
16.70 \\
8.77 \\
7.90 \\
16.33 \\
32.56 \\
7.06 \\
\text { No Data }\end{array}$ & $\begin{array}{l}\text { No Detect } \\
\text { No Detect } \\
\text { No Detect } \\
\text { No Detect } \\
\text { No Detect } \\
\text { No Detect } \\
\text { No Detect } \\
\text { No Detect } \\
\text { No Detect } \\
\text { No Detect } \\
\text { No Detect } \\
\text { No Detect }\end{array}$ & $\begin{array}{r}5770 \\
18800 \\
8730 \\
18300 \\
15800 \\
13600 \\
5720 \\
10200 \\
6970 \\
5280 \\
13200 \\
12700\end{array}$ & $\begin{array}{r}17400 \\
265000 \\
92800 \\
133000 \\
66600 \\
23200 \\
113000 \\
41900 \\
19800 \\
31900 \\
60800 \\
60600\end{array}$ & $\begin{array}{r}736 \\
5010 \\
998 \\
9270 \\
3690 \\
2720 \\
645 \\
1900 \\
239 \\
421 \\
2760 \\
2760\end{array}$ & $\begin{array}{l}<22.0 \\
182 \\
<22.0 \\
148 \\
248 \\
<22.0 \\
<22.0 \\
265 \\
<22.0 \\
<22.0 \\
95.4 \\
94.6\end{array}$ & $\begin{array}{r}324000 \\
1430000 \\
394000 \\
708000 \\
448000 \\
88600 \\
316000 \\
637000 \\
410000 \\
454000 \\
353000 \\
354000\end{array}$ & $\begin{array}{c}\sim 189 \\
-415 \\
14200 \\
1110 \\
1770 \\
-36.0 \\
1170 \\
\sim 184 \\
\sim 22.8 \\
-326 \\
10800 \\
10900\end{array}$ \\
\hline \multicolumn{12}{|l|}{ Surface Hater } \\
\hline $\begin{array}{l}\text { Lower Gunnison } \\
\text { Middle Gunnison } \\
\text { North Pond } \\
\text { South Pond } \\
\text { Upper Gunnison } \\
\text { Upper Mid Gunnison }\end{array}$ & $\begin{array}{l}\text { MLY }-829 \\
\text { MLY }-828 \\
\text { MLY-831 } \\
\text { MLY }-833 \\
\text { MLY }-826 \\
\text { MLY-827 }\end{array}$ & $\begin{array}{l}06 / 15 / 1992 \\
06 / 15 / 1992 \\
06 / 16 / 1992 \\
06 / 16 / 1992 \\
06 / 15 / 1992 \\
06 / 15 / 1992\end{array}$ & $\begin{array}{l}<9.0 \\
<9.0 \\
<9.0 \\
<9.0 \\
<9.0 \\
<9.0\end{array}$ & $\begin{array}{l}\text { No Data } \\
\text { No Data } \\
\text { No Data } \\
\text { No Data } \\
\text { No Data } \\
\text { No Data }\end{array}$ & $\begin{array}{l}\text { No Data } \\
\text { No Data } \\
\text { No Data } \\
\text { No Data } \\
\text { No Data } \\
\text { No Data }\end{array}$ & $\begin{array}{l}\sim 1680 \\
\sim 1320 \\
19700 \\
20500 \\
\sim 1700 \\
\sim 1500\end{array}$ & $\begin{array}{r}24800 \\
25200 \\
154000 \\
76800 \\
25600 \\
25200\end{array}$ & $\begin{array}{l}\sim 6.0 \\
-10.5 \\
121 \\
1820 \\
\sim 6.3 \\
\sim 8.7\end{array}$ & $\begin{array}{r}<22.0 \\
<22.0 \\
50.9 \\
106 \\
<22.0 \\
<22.0\end{array}$ & $\begin{array}{r}37000 \\
37900 \\
709000 \\
390000 \\
38700 \\
38000\end{array}$ & $\begin{array}{l}2730 \\
2780 \\
-116 \\
6110 \\
4370 \\
2720\end{array}$ \\
\hline \multicolumn{12}{|l|}{$Q A / Q C$} \\
\hline $\begin{array}{l}\text { Equipment Blank } \\
\text { Trip Blank } \\
\text { Trip Blank }\end{array}$ & $\begin{array}{l}\text { MLY Y } 832 \\
\text { MLY }-830 \\
\text { MLY-835 }\end{array}$ & $\begin{array}{l}06 / 16 / 1992 \\
06 / 16 / 1992 \\
06 / 17 / 1992\end{array}$ & $\begin{array}{l}<9.0 \\
\text { No Data } \\
\text { No Data }\end{array}$ & $\begin{array}{l}\text { No Data } \\
\text { No Data } \\
\text { No Data }\end{array}$ & $\begin{array}{l}\text { No Data } \\
\text { No Data } \\
\text { No Data }\end{array}$ & $\begin{array}{l}<1100 \\
\text { No Data } \\
\text { No Data }\end{array}$ & $\begin{array}{l}<53.0 \\
\text { No Data } \\
\text { No Data }\end{array}$ & $\begin{array}{l}<1.0 \\
\text { No Data } \\
\text { No Data }\end{array}$ & $\begin{array}{l}<22.0 \\
\text { No Data } \\
\text { No Data }\end{array}$ & $\begin{array}{l}\sim 97.4 \\
\text { No Data } \\
\text { No Data }\end{array}$ & $\begin{array}{l}-54.0 \\
\text { No Data } \\
\text { No Data }\end{array}$ \\
\hline
\end{tabular}

$a_{A} "<"$ indicates that the maximum concentration was below detection 1 imits (number shown is detection 1 imit). A " $"$ indicates an approximate value (the value was outside the limits for which the instrument was calibrated). 
Table A-19 (continued). Water Chemistry Data for Grand Junction, June 15 through June 19, 1992a

\begin{tabular}{|c|c|c|c|c|c|c|c|c|c|c|c|}
\hline $\begin{array}{l}\text { Sample } \\
\text { Location }\end{array}$ & $\begin{array}{l}\text { Ticket } \\
\text { Number }\end{array}$ & $\begin{array}{l}\text { Sample } \\
\text { Date }\end{array}$ & $\begin{array}{c}\mathrm{Pb} \\
(\mu \mathrm{g} / \mathrm{L})\end{array}$ & $\begin{array}{l}\text { Pesticide } \\
\text { ( } \mu g / L)\end{array}$ & pH & $\begin{array}{l}\mathrm{Ra}-226 \\
(\mathrm{pCi} / \mathrm{L})^{\mathrm{b}}\end{array}$ & $\begin{array}{l}\mathrm{Ra}-228 \\
(\mathrm{pCi} / \mathrm{L})^{\mathrm{b}}\end{array}$ & $\underset{(\mu g / L)}{S e}$ & $\begin{array}{c}\text { Seanivolatile } \\
(\mu, g / L)\end{array}$ & $\underset{(\mu g / L)}{\mathrm{SO}_{4}}$ & $\underset{(\mathrm{mg} / \mathrm{L})}{\mathrm{TDS}}$ \\
\hline Ground Mater & & & & & $\cdot$ & & & & & & \\
\hline $\begin{array}{l}1-9 S A \\
10-19 N \\
11-12 N A \\
13-16 N A \\
14-13 N A \\
14-6 N A \\
5-12 N A \\
\text { GJ84-04 } \\
\text { GJ84-09 } \\
\text { GJ84-10 } \\
\text { GJ87-15 } \\
\text { GJ87-15 (Dup) }\end{array}$ & 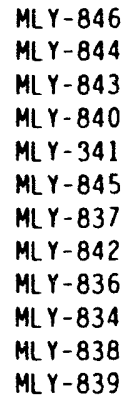 & $\begin{array}{l}06 / 19 / 1992 \\
06 / 18 / 1992 \\
0 c, 9 / 1992 \\
06 / 18 / 1992 \\
06 / 18 / 1992 \\
06 / 19 / 1992 \\
06 / 17 / 1992 \\
06 / 18 / 1992 \\
06 / 17 / 1992 \\
06 / 16 / 1992 \\
06 / 17 / 1992 \\
06 / 17 / 1992\end{array}$ & $\begin{array}{l}<1.0 \\
<1.0 \\
<1.0 \\
<1.0 \\
<1.0 \\
<1.0 \\
<1.0 \\
<1.0 \\
<1.0 \\
<1.0 \\
<1.0 \\
<1.0\end{array}$ & $\begin{array}{l}\text { No Detect } \\
\text { No Detect } \\
\text { No Detect } \\
\text { No Detect } \\
\text { No Detect } \\
\text { No Detect } \\
\text { No Detect } \\
\text { No Detect } \\
\text { No Detect } \\
\text { No Detect } \\
\text { No Detect } \\
\text { No Detect }\end{array}$ & $\begin{array}{r}7.97 \\
7.38 \\
7.30 \\
6.98 \\
7.13 \\
7.41 \\
7.29 \\
7.39 \\
7.48 \\
7.57 \\
7.28 \\
\text { No Data }\end{array}$ & $\begin{array}{l}<0.1 \\
0.1 \\
0.1 \\
0.1 \\
0.1 \\
0.1 \\
0.2 \\
0.1 \\
0.1 \\
0.1 \\
0.1 \\
0.1\end{array}$ & $\begin{array}{l}<1 \\
<1 \\
<1 \\
<1 \\
<1 \\
<1 \\
<1 \\
<1 \\
<1 \\
<1 \\
<1 \\
<1\end{array}$ & $\begin{array}{r}<2.0 \\
-2.5 \\
29.4 \\
-31.0 \\
16.7 \\
<2.0 \\
11.1 \\
<2.0 \\
<2.0 \\
\sim 2.5 . \\
57.7 \\
41.8\end{array}$ & $\begin{array}{l}\text { No Detect } \\
\text { No Detect } \\
\text { No Detect } \\
\text { No Detect } \\
\text { No Detect } \\
\text { No Detect } \\
\text { No Detect } \\
\text { No Detect } \\
\text { No Detect } \\
\text { No Detect } \\
\text { No Detect } \\
\text { No Detect }\end{array}$ & $\begin{array}{r}327000 \\
3980000 \\
1400000 \\
2350000 \\
1470000 \\
737000 \\
1290000 \\
1460000 \\
929000 \\
1100000 \\
<210 \\
<210\end{array}$ & $\begin{array}{r}1400 \\
7500 \\
2780 \\
4800 \\
2900 \\
780 \\
2720 \\
2780 \\
1800 \\
2080 \\
2360 \\
2320\end{array}$ \\
\hline \multicolumn{12}{|l|}{ Surface Water } \\
\hline $\begin{array}{l}\text { Lower Gunnison } \\
\text { Middle Gunnison } \\
\text { North Pond } \\
\text { South Pond } \\
\text { Upper Gunnison } \\
\text { Upper Mid Gunnison }\end{array}$ & $\begin{array}{l}\text { MLY Y } 829 \\
\text { MLY } Y-828 \\
\text { MLY }-831 \\
\text { MLY } Y-833 \\
\text { MLY-826 } \\
\text { MLY-827 }\end{array}$ & $\begin{array}{l}06 / 15 / 1992 \\
06 / 15 / 1992 \\
06 / 16 / 1992 \\
06 / 16 / 1992 \\
06 / 15 / 1992 \\
06 / 15 / 1992\end{array}$ & $\begin{array}{l}<1.0 \\
<1.0 \\
<1.0 \\
<1.0 \\
<1.0 \\
<1.0\end{array}$ & $\begin{array}{l}\text { No Data } \\
\text { No Data } \\
\text { No Data. } \\
\text { No Data } \\
\text { No Data } \\
\text { No Data }\end{array}$ & $\begin{array}{l}8.49 \\
8.08 \\
8.50 \\
7.03 \\
7.50 \\
8.18\end{array}$ & $\begin{array}{l}0.1 \\
0.1 \\
0.2 \\
0.4 \\
0.1 \\
0.1\end{array}$ & $\begin{array}{l}<1 \\
<1 \\
<1 \\
<1 \\
<1 \\
<1\end{array}$ & $\begin{array}{r}5.5 \\
7.2 \\
6.5 \\
-5.2 \\
-4.8 \\
-4.5\end{array}$ & $\begin{array}{l}\text { No Data } \\
\text { No Data } \\
\text { No Data } \\
\text { No Data } \\
\text { No Data } \\
\text { No Data }\end{array}$ & $\begin{array}{r}228000 \\
236000 \\
2290000 \\
1540000 \\
244000 \\
220000\end{array}$ & $\begin{array}{r}560 \\
580 \\
4140 \\
2940 \\
560 \\
560\end{array}$ \\
\hline \multicolumn{12}{|l|}{$Q A / Q C$} \\
\hline $\begin{array}{l}\text { Equipment Blank } \\
\text { Trip Blank } \\
\text { Trip Blank }\end{array}$ & $\begin{array}{l}\text { MLY Y-832 } \\
\text { MLY Y } 830 \\
\text { MLY-835 }\end{array}$ & $\begin{array}{l}06 / 16 / 1992 \\
06 / 16 / 1992 \\
06 / 17 / 1992\end{array}$ & $\begin{array}{l}<1.0 \\
\text { No Data } \\
\text { No Data }\end{array}$ & $\begin{array}{l}\text { No Data } \\
\text { No Data } \\
\text { No Data }\end{array}$ & $\begin{array}{l}\text { No Data } \\
\text { No Data } \\
\text { No Data }\end{array}$ & $\begin{array}{l}\quad<0.1 \\
\text { No Data } \\
\text { No Data }\end{array}$ & $\begin{array}{l}\text { <1 } \\
\text { No Data } \\
\text { No Data }\end{array}$ & $\begin{array}{l}<2.0 \\
\text { No Data } \\
\text { No Data }\end{array}$ & $\begin{array}{l}\text { No Data } \\
\text { No Data } \\
\text { No Data }\end{array}$ & $\begin{array}{l}209 \\
\text { No Data } \\
\text { No Data }\end{array}$ & $\begin{array}{l}220 \\
\text { No Data } \\
\text { No Data }\end{array}$ \\
\hline
\end{tabular}

a " $<$ " indicates that the maximum concentration was below detection limits (number shown is detection limit). A " $"$ indicates an approximate value (the value was outside the limits for which the instrument was calibrated).

bThe values 1 isted multiplied by $10^{-9}$ will result in $\mu \mathrm{Ci} / \mathrm{mL}$. 
Iatile A 19 (continued) Water Chemistry Data for Grand Junction, June 15 through June 19, 1992a

\begin{tabular}{|c|c|c|c|c|c|c|c|c|c|}
\hline $\begin{array}{l}\text { Sample } \\
\text { location }\end{array}$ & $\begin{array}{l}\text { Nicket } \\
\text { Number }\end{array}$ & $\begin{array}{c}\text { Sample } \\
\text { Date }\end{array}$ & $\begin{array}{l}\text { lemperature } \\
\text { (degrees C) }\end{array}$ & $\begin{array}{l}1 \mathrm{lh}-230 \\
(\mathrm{pCi} / \mathrm{L})^{b}\end{array}$ & $\begin{array}{l}10 C \\
(m g / L)\end{array}$ & $\begin{array}{c}U-234 \\
(\mathrm{pCi} / L)^{b}\end{array}$ & $\begin{array}{l}U-238 \\
(\mathrm{pCi} / L)^{b}\end{array}$ & $\begin{array}{l}v \\
(\mu g / L)\end{array}$ & $\begin{array}{r}\text { Volatile } \\
(\mu g / L)\end{array}$ \\
\hline \multicolumn{10}{|l|}{ Ground Vater } \\
\hline $\begin{array}{l}1.95 A \\
10-19 N \\
11.12 N A \\
13-16 N A \\
14-13 N A \\
14-5 N A \\
5-12 N A \\
\text { GJ84 04 } \\
\text { GJ84.09 } \\
\text { GJ84 10 } \\
\text { GJ87-15 } \\
\text { GJ87-15 (DUD) }\end{array}$ & $\begin{array}{l}M ! Y \quad 845 \\
M L Y \quad 844 \\
M L Y \cdot 843 \\
M L Y-840 \\
M L Y-841 \\
M L Y-845 \\
M L Y-837 \\
M L Y-842 \\
M L Y \cdot 836 \\
M L Y-834 \\
M L Y \cdot 838 \\
M L Y-839\end{array}$ & $\begin{array}{l}06 / 19 / 1992 \\
06 / 18 / 1992 \\
06 / 18 / 1992 \\
06 / 18 / 1992 \\
06 / 18 / 1992 \\
06 / 19 / 1992 \\
06 / 17 / 1992 \\
06 / 18 / 1992 \\
06 / 17 / 1992 \\
06 / 16 / 1992 \\
06 / 17 / 1992 \\
06 / 17 / 1992\end{array}$ & $\begin{array}{l}14.8 \\
11.0 \\
13.3 \\
13.1 \\
14.1 \\
11.8 \\
14.1 \\
13.2 \\
14.4 \\
15.3 \\
15.6 \\
\text { No Data }\end{array}$ & $\begin{array}{l}<0.3 \\
<0.5 \\
<0.3 \\
<0.3 \\
<0.5 \\
<0.3 \\
<0.3 \\
<0.5 \\
<0.3 \\
<0.3 \\
<0.3 \\
<0.3\end{array}$ & $\begin{array}{r}1.1 \\
13.8 \\
4.1 \\
15.7 \\
5.3 \\
1.2 \\
3.7 \\
5.5 \\
0.6 \\
1.0 \\
4.4 \\
4.5\end{array}$ & $\begin{array}{r}10.99 \\
289.74 \\
108.91 \\
112.04 \\
289.96 \\
24.19 \\
21.48 \\
223.09 \\
6.84 \\
13.42 \\
157.79 \\
149.35\end{array}$ & $\begin{array}{r}8.02 \\
295.69 \\
93.39 \\
114.82 \\
282.41 \\
24.49 \\
15.14 \\
198.97 \\
4.17 \\
9.35 \\
136.10 \\
141.42\end{array}$ & $\begin{array}{l}<7.0 \\
<7.0 \\
138 \\
\sim 19.5 \\
\sim 17.4 \\
\sim 12.2 \\
<7.0 \\
\sim 14.5 \\
<7.0 \\
<7.0 \\
223 \\
219\end{array}$ & $\begin{array}{l}\text { No Detect } \\
\text { No Detect } \\
\text { No Detect } \\
\text { No Detect } \\
\text { No Detect } \\
\text { No Detect } \\
\text { No Detect } \\
\text { No Detect } \\
\text { No Detect } \\
\text { No Detect } \\
\text { No Detect } \\
\text { No Detect }\end{array}$ \\
\hline \multicolumn{10}{|l|}{ Surface Hater } \\
\hline $\begin{array}{l}\text { Lower Gunnison } \\
\text { Middle Gunnison } \\
\text { North Pond } \\
\text { South Pond } \\
\text { Upper Gunnison } \\
\text { Upper Mid Gunnison }\end{array}$ & $\begin{array}{l}M L Y-829 \\
M L Y-828 \\
M L Y-831 \\
M L Y-833 \\
M L Y-826 \\
M L Y-827\end{array}$ & $\begin{array}{l}06 / 15 / 1992 \\
06 / 15 / 1992 \\
06 / 16 / 1992 \\
06 / 16 / 19 ? 2 \\
06 / 15 / 1992 \\
06 / 15 / 1992\end{array}$ & $\begin{array}{l}18.5 \\
18.3 \\
21.2 \\
19.8 \\
15.8 \\
16.5\end{array}$ & $\begin{array}{l}<0.3 \\
<0.3 \\
<0.6 \\
<0.6 \\
<0.3 \\
<0.3\end{array}$ & $\begin{array}{r}5.0 \\
3.8 \\
25.9 \\
25.2 \\
5.3 \\
5.6\end{array}$ & $\begin{array}{r}4.22 \\
3.14 \\
151.56 \\
148.27 \\
2.27 \\
2.78\end{array}$ & $\begin{array}{r}3.10 \\
2.60 \\
143.01 \\
150.19 \\
2.08 \\
2.05\end{array}$ & $\begin{array}{r}<7.0 \\
<7.0 \\
<7.0 \\
\sim 33.1 \\
<7.0 \\
<7.0\end{array}$ & $\begin{array}{l}\text { No Data } \\
\text { No Data } \\
\text { No Data } \\
\text { No Data } \\
\text { No Data } \\
\text { No Data }\end{array}$ \\
\hline \multicolumn{10}{|l|}{ QA/OC } \\
\hline $\begin{array}{l}\text { Equipment Blank } \\
\text { Trip Blank } \\
\text { Trip Blank }\end{array}$ & $\begin{array}{l}\text { MLY } Y-832 \\
\text { MLY }-830 \\
\text { MLY }-835\end{array}$ & $\begin{array}{l}06 / 16 / 1992 \\
06 / 16 / 1992 \\
06 / 17 / 1992\end{array}$ & $\begin{array}{l}\text { No Data } \\
\text { No Data } \\
\text { No Data }\end{array}$ & $\begin{array}{l}<0.3 \\
\text { No Data } \\
\text { No Data }\end{array}$ & $\begin{array}{ll} & 0.6 \\
\text { No Data } & \\
\text { No Data }\end{array}$ & $\begin{array}{l}0.48 \\
\text { No Data } \\
\text { No Data }\end{array}$ & $\begin{array}{ll} & 0.62 \\
\text { No Data } \\
\text { No Data }\end{array}$ & $\begin{array}{l}<7.0 \\
\text { No Data } \\
\text { No Data }\end{array}$ & $\begin{array}{l}\text { No Data } \\
\text { No Detect } \\
\text { No Detect }\end{array}$ \\
\hline
\end{tabular}

$a_{A} "<"$ indicates that the maximum concentration was below detection limits (number shown is detection

limit). A " " indicates an approximate value (the value was outside the limits for which the instrument was calibrated).

bihe values listed multiplied by $10^{-9}$ will result in $\mu \mathrm{Ci} / \mathrm{mL}$. 
Table A-20. Water Chemistry Data for Grand Junction, September 8 through September 14, 1992a

\begin{tabular}{|c|c|c|c|c|c|c|c|c|c|c|c|}
\hline $\begin{array}{l}\text { Sample } \\
\text { Location }\end{array}$ & $\begin{array}{l}\text { Ticket } \\
\text { Number }\end{array}$ & $\begin{array}{l}\text { Sample } \\
\text { Date }\end{array}$ & $\begin{array}{c}\text { Alky } \\
\text { (ppm) } \\
\text { (CaCO3) }\end{array}$ & $\begin{array}{c}\text { Alpha } \\
(\mathrm{pC} i / L)^{b}\end{array}$ & $\underset{(\mu g / L)}{\text { As }}$ & $\begin{array}{c}8 \mathrm{a} \\
(\mu \mathrm{g} / \mathrm{L})\end{array}$ & $\underset{(\mu g / L)}{C a}$ & $\underset{(p g / L)}{C d}$ & $\begin{array}{c}\text { CDT } \\
\text { (pmos/cm) }\end{array}$ & $\underset{(\mu g / L)}{C 1}$ & $\underset{(\mu g / L)}{C r}$ \\
\hline \multicolumn{12}{|l|}{ Ground Vater } \\
\hline $\begin{array}{l}1-9 S A \\
10-19 N \\
11-12 N A \\
11-15 \\
13-16 N A \\
14-13 N A \\
14-6 N A \\
5-12 N A \\
\text { GJ84-04 } \\
\text { GJ84-04 (Dup) } \\
\text { GJ84-09 } \\
\text { GJ84-10 } \\
\text { GJ87-15 }\end{array}$ & $\begin{array}{l}\text { MLY Y-749 } \\
\text { NAW-293 } \\
\text { NAW-292 } \\
\text { MLY-900 } \\
\text { NAW-294 } \\
\text { NAW-295 } \\
\text { NAW-290 } \\
\text { MLY-750 } \\
\text { MLY-747 } \\
\text { MLY-748 } \\
\text { NAW-289 } \\
\text { MLY-746 } \\
\text { NAW-291 }\end{array}$ & $\begin{array}{l}09 / 09 / 1992 \\
09 / 10 / 1992 \\
09 / 10 / 1992 \\
09 / 09 / 1992 \\
09 / 11 / 1992 \\
09 / 11 / 1992 \\
09 / 10 / 1992 \\
09 / 09 / 1992 \\
09 / 08 / 1992 \\
09 / 08 / 1992 \\
09 / 09 / 1992 \\
09 / 08 / 1992 \\
09 / 10 / 1992\end{array}$ & $\begin{array}{l}236 \\
594 \\
331 \\
281 \\
530 \\
391 \\
161 \\
403 \\
324 \\
324 \\
273 \\
164 \\
294\end{array}$ & $\begin{array}{r}<40 \\
1200 \\
220 \\
1100 \\
1000 \\
900 \\
<30 \\
<80 \\
510 \\
480 \\
<50 \\
<60 \\
240\end{array}$ & $\begin{array}{c}<3.0 \\
<30.0 \\
33.6 \\
<3.0 \\
<30.0 \\
14.7 \\
225 \\
<3.0 \\
-3.6 \\
<3.0 \\
<30.0 \\
<30.0 \\
87.8\end{array}$ & $\begin{array}{r}\sim 14.3 \\
\sim 15.9 \\
\sim 24.6 \\
\sim 12.3 \\
\sim 19.2 \\
\sim 18.0 \\
\sim 43.9 \\
\sim 20.2 \\
\sim 16.5 \\
\sim 19.4 \\
\sim 12.7 \\
<7.0 \\
\sim 23.6\end{array}$ & $\begin{array}{l}106000 \\
562000 \\
329000 \\
158000 \\
482000 \\
136000 \\
102000 \\
338000 \\
170000 \\
172000 \\
119000 \\
140000 \\
286000\end{array}$ & $\begin{array}{l}<1.0 \\
<1.0 \\
<1.0 \\
<1.0 \\
<1.0 \\
<1.0 \\
<1.0 \\
<1.0 \\
<1.0 \\
<1.0 \\
<1.0 \\
<1.0 \\
<1.0\end{array}$ & $\begin{array}{l}1894 \\
9100 \\
3560 \\
2586 \\
5370 \\
3720 \\
1128 \\
3300 \\
. \quad 3630 \\
3630 \\
2330 \\
2620 \\
3110\end{array}$ & $\begin{array}{r}19100 \\
713000 \\
187000 \\
71300 \\
287000 \\
158000 \\
15400 \\
166000 \\
51000 \\
54200 \\
45000 \\
94500 \\
164000\end{array}$ & $\begin{array}{l}<6.0 \\
<6.0 \\
<6.0 \\
<6.0 \\
<6.0 \\
<6.0 \\
<6.0 \\
<6.0 \\
<6.0 \\
<6.0 \\
<6.0 \\
<6.0 \\
<6.0\end{array}$ \\
\hline \multicolumn{12}{|l|}{ Surf ace Mater } \\
\hline $\begin{array}{l}\text { Lower Gunnison } \\
\text { Middle Gunnison } \\
\text { North Pond } \\
\text { South Pond } \\
\text { Upper Gunnison } \\
\text { Upper Mid Gunnison }\end{array}$ & $\begin{array}{l}\text { NAW-299 } \\
\text { NAW-298 } \\
\text { NAW-300 } \\
\text { NAW-302 } \\
\text { NAW-296 } \\
\text { NAW-297 }\end{array}$ & $\begin{array}{l}09 / 14 / 1992 \\
09 / 14 / 1992 \\
09 / 14 / 1992 \\
09 / 14 / 1992 \\
09 / 14 / 1992 \\
09 / 14 / 1992\end{array}$ & $\begin{array}{r}133 \\
148 \\
52 \\
152 \\
131 \\
151\end{array}$ & $\begin{array}{r}<30 \\
30 \\
420 \\
490 \\
<30 \\
<20\end{array}$ & $\begin{array}{r}<3.0 \\
<3.0 \\
<30.0 \\
15.3 \\
<3.0 \\
<3.0\end{array}$ & $\begin{array}{l}\sim 36.5 \\
-37.1 \\
-17.3 \\
\sim 26.5 \\
\sim 35.5 \\
-37.7\end{array}$ & $\begin{array}{l}121000 \\
127000 \\
352000 \\
408000 \\
128000 \\
134000\end{array}$ & $\begin{array}{l}<1.0 \\
<1.0 \\
<1.0 \\
<1.0 \\
<1.0 \\
<1.0\end{array}$ & $\begin{array}{l}1184 \\
1085 \\
4850 \\
3890 \\
1125 \\
1163\end{array}$ & $\begin{array}{r}9810 \\
9510 \\
414000 \\
204000 \\
9580 \\
9680\end{array}$ & $\begin{array}{l}<6.0 \\
<6.0 \\
<6.0 \\
<6.0 \\
<6.0 \\
<6.0\end{array}$ \\
\hline \multicolumn{12}{|l|}{ QA/QC } \\
\hline $\begin{array}{l}\text { Equipment Blank } \\
\text { Trip 8lank }\end{array}$ & $\begin{array}{l}\text { NAW-301 } \\
\text { MLY-525 }\end{array}$ & $\begin{array}{l}09 / 14 / 1992 \\
09 / 11 / 1992\end{array}$ & $\begin{array}{l}\text { No Data } \\
\text { No Data }\end{array}$ & $\begin{array}{l}<5 \\
\text { No Data }\end{array}$ & $\begin{array}{c}<3.0 \\
\text { No Data }\end{array}$ & $\begin{array}{c}<7.0 \\
\text { No Data }\end{array}$ & $\begin{array}{l}<24.0 \\
\text { No Data }\end{array}$ & $\begin{array}{c}<1.0 \\
\text { No Data }\end{array}$ & $\begin{array}{l}\text { No Data } \\
\text { No Data }\end{array}$ & $\begin{array}{c}-62.7 \\
\text { No Data }\end{array}$ & $\begin{array}{c}<6.0 \\
\text { No Data }\end{array}$ \\
\hline
\end{tabular}

$a_{A} "<"$ indicates that the maximum concentration was below detection limits (number shown is detection limit). A " $"$ indicates an approximate value (the value was outside the limits for which the instrument was calibrated).

bThe values listed multiplied by $10^{-9}$ will result in $\mu \mathrm{Ci} / \mathrm{mL}$. 
Table A-20 (continued). Water Chemistry Data for Grand Junciion, September 8 through September 14, 1992

\begin{tabular}{|c|c|c|c|c|c|c|c|c|c|c|c|}
\hline $\begin{array}{l}\text { Sample } \\
\text { Location }\end{array}$ & $\begin{array}{l}\text { Ticket } \\
\text { Number }\end{array}$ & $\begin{array}{l}\text { Sample } \\
\text { Date }\end{array}$ & $\begin{array}{c}F e \\
(\mu \cdot g / L)\end{array}$ & $\begin{array}{l}\mathrm{H}_{2} \mathrm{O} \text { Depth } \\
\text { (Feet) }\end{array}$ & $\begin{array}{l}\text { Herbicide } \\
\qquad(\mu \mathrm{g} / \mathrm{L})\end{array}$ & $\underset{(\mu g / L)}{K}$ & $\underset{(\mu g / L)}{\operatorname{mg}}$ & $\operatorname{lm}_{(\mu g / L)}$ & $\underset{(\mu g / L)}{10}$ & $\underset{(\mu g / L)}{\mathrm{Ma}}$ & $\underset{(\mu g / L)}{m 0_{3}}$ \\
\hline \multicolumn{12}{|l|}{ Ground Vater } \\
\hline $\begin{array}{l}1-9 S A \\
10-19 N \\
11-12 N A \\
11-1 S \\
13-16 N A \\
14-13 N A \\
14-6 N A \\
5-12 N A \\
\text { GJ84-04 } \\
\text { GJ84-04 (Dup) } \\
\text { GJ84-09 } \\
\text { GJ84-10 } \\
\text { GJ87-15 }\end{array}$ & $\begin{array}{l}\text { MLY } Y-749 \\
\text { NAW-293 } \\
\text { NAW-292 } \\
\text { MLY-900 } \\
\text { NAW-294 } \\
\text { NAW-295 } \\
\text { NAW-290 } \\
\text { MLY-750 } \\
\text { MLY-747 } \\
\text { MLY-748 } \\
\text { NAW-289 } \\
\text { MLY-746 } \\
\text { NAW-291 }\end{array}$ & $\begin{array}{l}09 / 09 / 1992 \\
09 / 10 / 1992 \\
09 / 10 / 1992 \\
09 / 09 / 1992 \\
09 / 11 / 1992 \\
09 / 11 / 1992 \\
09 / 10 / 1992 \\
09 / 09 / 1992 \\
09 / 08 / 1992 \\
09 / 08 / 1992 \\
09 / 09 / 1992 \\
09 / 08 / 1992 \\
09 / 10 / 1992\end{array}$ & $\begin{array}{l}<10.0 \\
493 \\
<10.0 \\
<10.0 \\
506 \\
<10.0 \\
1350 \\
<10.0 \\
\sim 19.0 \\
-15.2 \\
\sim 69.0 \\
<10.0 \\
<10.0\end{array}$ & $\begin{array}{r}12.74 \\
12.56 \\
5.77 \\
16.65 \\
4.31 \\
5.53 \\
20.14 \\
7.65 \\
8.61 \\
8.61 \\
20.57 \\
33.7 \\
8.24\end{array}$ & $\begin{array}{l}\text { No Detect } \\
\text { No Detect } \\
\text { No Detect } \\
\text { No Detect } \\
\text { No Detect } \\
\text { No Detect } \\
\text { No Detect } \\
\text { No Detect } \\
\text { No Detect } \\
\text { No Detect } \\
\text { No Detect } \\
\text { No Detect } \\
\text { No Detect }\end{array}$ & $\begin{array}{r}5700 \\
25800 \\
10300 \\
7040 \\
21000 \\
19600 \\
14900 \\
5940 \\
10500 \\
11200 \\
7600 \\
\sim 4600 \\
15600\end{array}$ & $\begin{array}{r}16500 \\
340000 \\
97200 \\
58300 \\
123000 \\
74800 \\
21500 \\
122000 \\
42200 \\
42300 \\
19400 \\
32500 \\
66200\end{array}$ & $\begin{array}{r}822 \\
5630 \\
1140 \\
149 \\
8800 \\
4570 \\
3230 \\
699 \\
2140 \\
2160 \\
160 \\
493 \\
3280\end{array}$ & $\begin{array}{l}-12.1 \\
303 \\
\sim 28.9 \\
434 \\
213 \\
276 \\
\sim 13.8 \\
\sim 16.1 \\
290 \\
288 \\
\sim 8.4 \\
\sim 13.3 \\
97.3\end{array}$ & $\begin{array}{r}327000 \\
1910000 \\
432000 \\
382000 \\
761000 \\
71600 \\
96500 \\
335000 \\
683000 \\
674000 \\
396000 \\
447000 \\
375000\end{array}$ & $\begin{array}{c}-74.6 \\
-61.5 \\
15900 \\
1700 \\
-110 \\
-665 \\
-23.2 \\
744 \\
\sim 106 \\
-103 \\
\sim 45.9 \\
-260 \\
19300\end{array}$ \\
\hline \multicolumn{12}{|l|}{ Surface Mater } \\
\hline $\begin{array}{l}\text { Lower Gunni son } \\
\text { Middle Gunnison } \\
\text { North Pond } \\
\text { South Pond } \\
\text { Upper Gunnison } \\
\text { Upper Mid Gunnison }\end{array}$ & $\begin{array}{l}\text { NAW-299 } \\
\text { NAW-298 } \\
\text { NAW-300 } \\
\text { NAW-302 } \\
\text { NAW-296 } \\
\text { NAW-297 }\end{array}$ & $\begin{array}{l}09 / 14 / 1992 \\
09 / 14 / 1992 \\
09 / 14 / 1992 \\
09 / 14 / 1992 \\
09 / 14 / 1992 \\
09 / 14 / 1992\end{array}$ & $\begin{array}{l}<10.0 \\
<10.0 \\
<10.0 \\
<10.0 \\
<10.0 \\
<10.0\end{array}$ & $\begin{array}{l}\text { No Data } \\
\text { No Data } \\
\text { No Data } \\
\text { No Data } \\
\text { No Data } \\
\text { No Data }\end{array}$ & $\begin{array}{l}\text { No Data } \\
\text { No Data } \\
\text { No Data } \\
\text { No Data } \\
\text { No Data } \\
\text { No Data }\end{array}$ & $\begin{array}{l}\sim 3340 \\
\sim 3360 \\
26800 \\
25800 \\
\sim 3080 \\
\sim 3490\end{array}$ & $\begin{array}{r}41600 \\
43700 \\
230000 \\
87400 \\
43700 \\
45700\end{array}$ & $\begin{array}{c}16.2 \\
19.0 \\
26.7 \\
412 \\
21.2 \\
26.7\end{array}$ & $\begin{array}{c}\sim 4.7 \\
-4.5 \\
50.6 \\
148 \\
\sim 4.9 \\
\sim 4.6\end{array}$ & $\begin{array}{r}67100 \\
70800 \\
1030000 \\
461000 \\
70800 \\
74100\end{array}$ & $\begin{array}{l}5270 \\
5200 \\
\sim 99.4 \\
6600 \\
5250 \\
5400\end{array}$ \\
\hline \multicolumn{12}{|l|}{$Q A / Q C$} \\
\hline $\begin{array}{l}\text { Equipment Blank } \\
\text { Trip Blank }\end{array}$ & $\begin{array}{l}\text { NAW-301 } \\
\text { MLY-525 }\end{array}$ & $\begin{array}{l}09 / 14 / 1992 \\
09 / 11 / 1992\end{array}$ & $\begin{array}{l}<10.0 \\
\text { No Data }\end{array}$ & $\begin{array}{l}\text { No Data } \\
\text { No Data }\end{array}$ & $\begin{array}{l}\text { No Data } \\
\text { No Data }\end{array}$ & $\begin{array}{l}<1700 \\
\text { No Data }\end{array}$ & $\begin{array}{l}<95.0 \\
\text { No Data }\end{array}$ & $\begin{array}{c}<1.0 \\
\text { No Data }\end{array}$ & $\begin{array}{l}<1.0 \\
\text { No Data }\end{array}$ & $\begin{array}{l}-167 \\
\text { No Data }\end{array}$ & $\begin{array}{l}-44.4 \\
\text { No Data }\end{array}$ \\
\hline
\end{tabular}

$a_{A} "<"$ indicates that the maximum concentration was below detection limits (number shown is detection 1 imit). A " $"$ indicates an approximate value (the value was outside the limits for which the instrument was calibrated). 
Table A-20 (continued). Water Chemistry Data for Grand Juncticn, September 8 through September 14, 1992a

\begin{tabular}{|c|c|c|c|c|c|c|c|c|c|c|c|}
\hline $\begin{array}{l}\text { Sample } \\
\text { Location }\end{array}$ & $\begin{array}{l}\text { Ticket } \\
\text { Number }\end{array}$ & $\begin{array}{l}\text { Sample } \\
\text { Date }\end{array}$ & $\begin{array}{c}\mathrm{Pb} \\
(\mu \mathrm{g} / \mathrm{L})\end{array}$ & $\begin{array}{c}\text { Pesticide } \\
(\mu g / L)\end{array}$ & pH & $\begin{array}{r}R \bar{\alpha}-226 \\
(\mathrm{pCi} / \mathrm{L})^{b}\end{array}$ & $\begin{array}{r}R a-228 \\
(p C i / L)^{b}\end{array}$ & $\underset{(\mu / L)}{S e}$ & $\begin{array}{c}\text { Semivolatile } \\
(\mu g / L)\end{array}$ & $\mathrm{SO}_{4}$ & $\begin{array}{l}\text { TOS } \\
(m / L)\end{array}$ \\
\hline \multicolumn{12}{|l|}{ Ground Water } \\
\hline $\begin{array}{l}1-9 S A \\
10-19 N \\
11-12 N A \\
11-1 S \\
13-16 N A \\
14-13 N A \\
14-6 N A \\
5-12 N A \\
\text { GJ84-04 } \\
\text { GJ84-04 (Dup) } \\
\text { GJ84-09 } \\
\text { GJ84-10 } \\
\text { GJ87-15 }\end{array}$ & $\begin{array}{l}\text { MLY } Y-749 \\
\text { NAW-293 } \\
\text { NAW-292 } \\
\text { MLY-900 } \\
\text { NAW-294 } \\
\text { NAW-295 } \\
\text { NAW-290 } \\
\text { MLY-750 } \\
\text { MLY-747 } \\
\text { MLY-748 } \\
\text { NAW-289 } \\
\text { MLY-746 } \\
\text { NAW-291 }\end{array}$ & $\begin{array}{l}09 / 09 / 1992 \\
09 / 10 / 1992 \\
09 / 10 / 1992 \\
09 / 09 / 1992 \\
09 / 11 / 1992 \\
09 / 11 / 1992 \\
09 / 10 / 1992 \\
09 / 09 / 1992 \\
09 / 08 / 1992 \\
09 / 08 / 1992 \\
09 / 09 / 1992 \\
09 / 08 / 1992 \\
09 / 10 / 1992\end{array}$ & $\begin{array}{l}<1.0 \\
<1.0 \\
<1.0 \\
<1.0 \\
<1.0 \\
<1.0 \\
<1.0 \\
<1.0 \\
<1.0 \\
<1.0 \\
<1.0 \\
<1.0 \\
<1.0\end{array}$ & $\begin{array}{l}\text { No Detect } \\
\text { No Detect } \\
\text { No Detect } \\
\text { No Detect } \\
\text { No Detect } \\
\text { No Detect } \\
\text { No Detect } \\
\text { No Detect } \\
\text { No Detect } \\
\text { No Detect } \\
\text { No Detect } \\
\text { No Detect } \\
\text { No Detect }\end{array}$ & $\begin{array}{l}7.82 \\
6.97 \\
6.95 \\
7.30 \\
6.77 \\
6.82 \\
7.05 \\
7.12 \\
7.23 \\
7.23 \\
7.30 \\
7.52 \\
6.79\end{array}$ & $\begin{array}{r}<0.1 \\
0.2 \\
0.1 \\
<0.1 \\
0.1 \\
0.1 \\
<0.1 \\
0.0 \\
0.1 \\
<0.1 \\
<0.1 \\
0.1 \\
0.1\end{array}$ & $\begin{array}{l}<2 \\
<2 \\
<3 \\
<1 \\
<2 \\
<2 \\
<4 \\
<2 \\
<2 \\
<2 \\
<2 \\
<2 \\
<2\end{array}$ & $\begin{array}{r}<3.0 \\
<30.0 \\
46.8 \\
<3.0 \\
5.7 \\
11.5 \\
<3.0 \\
9.8 \\
<3.0 \\
<3.0 \\
<3.0 \\
<3.3 \\
36.3\end{array}$ & $\begin{array}{l}\text { See Table } \\
\text { See Table } \\
\text { See Table } \\
\text { See Table } \\
\text { See Table } \\
\text { See Table } \\
\text { See Table } \\
\text { See Table } \\
\text { See Table } \\
\text { See Table } \\
\text { See Table } \\
\text { See Table } \\
\text { See Table }\end{array}$ & $\begin{array}{r}707000 \\
4980000 \\
1480000 \\
1030000 \\
2330000 \\
1590000 \\
387000 \\
1440000 \\
706000 \\
750000 \\
909000 \\
1060000 \\
1210000\end{array}$ & $\begin{array}{r}1360 \\
8840 \\
2740 \\
1880 \\
4300 \\
3000 \\
740 \\
2680 \\
2680 \\
2700 \\
1440 \\
1720 \\
2360\end{array}$ \\
\hline \multicolumn{12}{|l|}{ Surface Uater } \\
\hline $\begin{array}{l}\text { Lower Gunnison } \\
\text { Middle Gunnison } \\
\text { North Pond } \\
\text { South Pond } \\
\text { Upper Gunnison } \\
\text { Upper Mid Gunnison }\end{array}$ & $\begin{array}{l}\text { NAW-299 } \\
\text { NAW-298 } \\
\text { NAW-300 } \\
\text { NAW-302 } \\
\text { NAW-296 } \\
\text { NAW-297 }\end{array}$ & $\begin{array}{l}09 / 14 / 1992 \\
09 / 14 / 1992 \\
09 / 14 / 1992 \\
09 / 14 / 1992 \\
09 / 14 / 1992 \\
09 / 14 / 1992\end{array}$ & $\begin{array}{r}<1.0 \\
3.5 \\
<1.0 \\
<1.0 \\
<1.0 \\
<1.0\end{array}$ & $\begin{array}{l}\text { No Data } \\
\text { No Data } \\
\text { No Data } \\
\text { No Data } \\
\text { No Data } \\
\text { No Data }\end{array}$ & $\begin{array}{l}8.52 \\
7.84 \\
9.97 \\
7.50 \\
7.59 \\
8.20\end{array}$ & $\begin{array}{r}<0.1 \\
0.1 \\
<0.2 \\
0.1 \\
0.2 \\
0.1\end{array}$ & $\begin{array}{l}<3 \\
<2 \\
<2 \\
<2 \\
<2 \\
<2\end{array}$ & $\begin{array}{r}6.2 \\
13.0 \\
<3.0 \\
<3.0 \\
7.4 \\
8.3\end{array}$ & $\begin{array}{l}\text { No Data } \\
\text { No Data } \\
\text { No Data } 3 \\
\text { No Data } 1 \\
\text { Mo Data } \\
\text { No Data }\end{array}$ & $\begin{array}{r}450000 \\
449000 \\
3200000 \\
1900000 \\
451000 \\
453000\end{array}$ & $\begin{array}{r}820 \\
820 \\
5300 \\
2900 \\
800 \\
600\end{array}$ \\
\hline \multicolumn{12}{|l|}{ QA/QC } \\
\hline $\begin{array}{l}\text { Equipment Blank } \\
\text { Trip Blank }\end{array}$ & $\begin{array}{l}\text { NAW-301 } \\
\text { MLY-525 }\end{array}$ & $\begin{array}{l}09 / 14 / 1992 \\
09 / 11 / 1992\end{array}$ & $\begin{array}{c}<1.0 \\
\text { No Data }\end{array}$ & $\begin{array}{l}\text { No Data } \\
\text { No Data }\end{array}$ & $\begin{array}{l}\text { No. Data } \\
\text { No Data }\end{array}$ & $\begin{array}{c}0.1 \\
\text { No Data }\end{array}$ & $\begin{array}{l}<2 \\
\text { No Data }\end{array}$ & $\begin{array}{c}<3.0 \\
\text { No Data }\end{array}$ & $\begin{array}{l}\text { No Data } \\
\text { No Data }\end{array}$ & $\begin{array}{l}\sim 57.0 \\
\text { No Data }\end{array}$ & $\begin{array}{l}400 \\
\text { No Data }\end{array}$ \\
\hline
\end{tabular}

$a_{A} "<"$ indicates that the maximum concentration was below detection limits (number shown is detection limit). A " $"$ indicates an approximate value (the value was outside the limits for which the instrument was calibrated); "See Table" indicates that the reader should refer to Table A-23 in this report for a list of detected constituents.

bThe values listed multiplied by $10^{-9}$ will result in $\mu \mathrm{Ci} / \mathrm{mL}$. 
Table A-20 (continued). Water Chemistry Data for Grand Junction, September 8 through September 14, 1992a

\begin{tabular}{|c|c|c|c|c|c|c|c|c|c|c|}
\hline $\begin{array}{l}\text { Sample } \\
\text { Location }\end{array}$ & $\begin{array}{l}\text { Ticket } \\
\text { Number }\end{array}$ & $\begin{array}{c}\text { Sample } \\
\text { Date }\end{array}$ & $\begin{array}{l}\text { Temperature } \\
\text { (degrees C) }\end{array}$ & $\begin{array}{l}\text { Th-230 } \\
(\mathrm{pCi} / L)^{\mathrm{b}}\end{array}$ & $\underset{(\mathrm{pCi} / \mathrm{L})^{\mathrm{b}}}{\mathrm{Th}-232}$ & $\underset{(\mathrm{mg} / \mathrm{L})}{\operatorname{TOC}}$ & $\underset{(\mathrm{pCi} / L)^{b}}{\mathrm{U}-234}$ & $\underset{(p C i / L)^{b}}{U-238}$ & $\underset{(\mu / L)}{v}$ & $\begin{array}{c}\text { Volatile } \\
(\mu g / L)\end{array}$ \\
\hline \multicolumn{11}{|l|}{ Ground Water } \\
\hline $\begin{array}{l}1-9 S A \\
10-19 N \\
11-12 N A \\
11-1 S \\
13-16 N A \\
14-13 N A \\
14-6 N A \\
5-12 N A \\
\text { GJ84-04 } \\
\text { GJ84-04 (Dup) } \\
\text { GJ84-09 } \\
\text { GJ84-10 } \\
\text { GJ87-15 }\end{array}$ & $\begin{array}{l}\text { MLY }-749 \\
\text { NAW-293 } \\
\text { NAW-292 } \\
\text { MLY-900 } \\
\text { NAW-294 } \\
\text { NAW-295 } \\
\text { NAW-290 } \\
\text { MLY-750 } \\
\text { MLY-747 } \\
\text { MLY-748 } \\
\text { NAW-289 } \\
\text { MLY }-746 \\
\text { NAW-291 }\end{array}$ & $\begin{array}{l}09 / 09 / 1992 \\
09 / 10 / 1992 \\
09 / 10 / 1992 \\
09 / 09 / 1992 \\
09 / 11 / 1992 \\
09 / 11 / 1992 \\
09 / 10 / 1992 \\
09 / 09 / 1992 \\
09 / 08 / 1992 \\
09 / 08 / 1992 \\
09 / 09 / 1992 \\
09 / 08 / 1992 \\
09 / 10 / 1992\end{array}$ & $\begin{array}{l}15.5 \\
13.9 \\
15.8 \\
14.9 \\
16.3 \\
17.4 \\
13.9 \\
14.9 \\
15.0 \\
15.0 \\
14.9 \\
15.4 \\
19.7\end{array}$ & $\begin{array}{l}<1.0 \\
<3 \\
<1.0 \\
<1.0 \\
<3 \\
9 \\
<1.0 \\
<1.0 \\
<4 \\
<4 \\
<1.0 \\
<1.0 \\
<1.0\end{array}$ & $\begin{array}{l}<1.0 \\
<1.7 \\
<1.0 \\
<1.0 \\
<1.9 \\
9 \\
<1.0 \\
<1.0 \\
<2 \\
<2 \\
<1.0 \\
<1.0 \\
<1.0\end{array}$ & $\begin{array}{r}0.9 \\
18.7 \\
3.2 \\
3.5 \\
14.6 \\
6.9 \\
3.6 \\
4.2 \\
5.2 \\
5.2 \\
0.6 \\
2.8 \\
4.1\end{array}$ & $\begin{array}{r}12.07 \\
575.13 \\
106.62 \\
532.46 \\
504.25 \\
352.31 \\
10.55 \\
27.63 \\
240.27 \\
259.37 \\
7.27 \\
8.20 \\
171.61\end{array}$ & $\begin{array}{r}7.90 \\
556.38 \\
99.68 \\
534.99 \\
462.67 \\
367.32 \\
9.56 \\
17.41 \\
241.81 \\
245.89 \\
4.04 \\
3.49 \\
161.05\end{array}$ & $\begin{array}{c}<7.0 \\
<7.0 \\
153 \\
<7.0 \\
-20.6 \\
\sim 21.3 \\
<7.0 \\
<7.0 \\
-16.0 \\
-16.3 \\
<7.0 \\
<7.0 \\
245\end{array}$ & $\begin{array}{l}\text { No Detect } \\
\text { No Detect } \\
\text { No Detect } \\
\text { No Detect } \\
\text { No Detect } \\
\text { No Detect } \\
\text { No Detect } \\
\text { No Detect } \\
\text { No Detect } \\
\text { No Detect } \\
\text { Ho Detect } \\
\text { No Detect } \\
\text { No Detect }\end{array}$ \\
\hline \multicolumn{11}{|l|}{ Surface Vater } \\
\hline $\begin{array}{l}\text { Lower Gunnison } \\
\text { Middle Gunnison } \\
\text { North Pond } \\
\text { South Pond } \\
\text { Upper Gunnison } \\
\text { Upper Mid Gunnison }\end{array}$ & $\begin{array}{l}\text { NAW-299 } \\
\text { NAW-298 } \\
\text { NAW-300 } \\
\text { NAW-302 } \\
\text { NAW-296 } \\
\text { NAW-297 }\end{array}$ & $\begin{array}{l}09 / 14 / 1992 \\
09 / 14 / 1992 \\
09 / 14 / 1992 \\
09 / 14 / 1992 \\
09 / 14 / 1992 \\
09 / 14 / 1992\end{array}$ & $\begin{array}{l}18.5 \\
17.9 \\
29.9 \\
22.1 \\
17.4 \\
17.4\end{array}$ & $\begin{array}{l}<1.0 \\
<1.0 \\
<7 \\
<4 \\
<1.0 \\
<1.0\end{array}$ & $\begin{array}{l}<1.0 \\
<1.0 \\
<7 \\
<4 \\
<1.0 \\
<1.0\end{array}$ & $\begin{array}{r}4.8 \\
5.3 \\
43.7 \\
15.2 \\
5.8 \\
4.8\end{array}$ & $\begin{array}{r}5.38 \\
5.61 \\
149.76 \\
227.85 \\
5.50 \\
5.48\end{array}$ & $\begin{array}{r}3.20 \\
3.17 \\
136.87 \\
246.97 \\
3.26 \\
3.14\end{array}$ & $\begin{aligned}<7.0 \\
<7.0 \\
\sim 15.0 \\
-7.7 \\
<7.0 \\
<7.0\end{aligned}$ & $\begin{array}{l}\text { No Data } \\
\text { No Data } \\
\text { No Data } \\
\text { No Data } \\
\text { No Data } \\
\text { No Data }\end{array}$ \\
\hline$Q A / Q C$ & & & & & & & & & & \\
\hline $\begin{array}{l}\text { Equipment Blank } \\
\text { Trip Blank }\end{array}$ & $\begin{array}{l}\text { NAW-301 } \\
\text { MLY }-525\end{array}$ & $\begin{array}{l}09 / 14 / 1992 \\
09 / 11 / 1992\end{array}$ & $\begin{array}{l}\text { No Data } \\
\text { No Data }\end{array}$ & $\begin{array}{c}<1.0 \\
\text { No Data }\end{array}$ & $\begin{array}{c}<1.0 \\
\text { No Data }\end{array}$ & $\begin{array}{l}\text { No Data } \\
\text { No Data }\end{array}$ & $\begin{array}{r}0.03 \\
\text { No Data }\end{array}$ & $\begin{array}{r}<0.15 \\
\text { No Data }\end{array}$ & $\begin{array}{l}<7.0 \\
\text { No Data }\end{array}$ & $\begin{array}{l}\text { No Data } \\
\text { No Detect }\end{array}$ \\
\hline
\end{tabular}

$a_{A}$ "<" indicates that the maximum concentration was below detection limits (number shown is detection 1 imit). A " " indicates an approximate value (the value was outside the limits for which the instrument was calibrated).

bThe values listed multiplied by $10^{-9}$ will result in $\mu \mathrm{Ci} / \mathrm{mL}$.
Thex 
Table A-21. Water Chemistry Data for Grand Junction, December 14 through December 18, 1992a

\begin{tabular}{|c|c|c|c|c|c|c|c|c|c|c|c|}
\hline $\begin{array}{l}\text { Sample } \\
\text { Location }\end{array}$ & $\begin{array}{l}\text { Ticket } \\
\text { Number }\end{array}$ & $\begin{array}{l}\text { Sample } \\
\text { Date }\end{array}$ & $\begin{array}{l}\text { Alky } \\
\text { (ppm) }\end{array}$ & $\begin{array}{c}\text { Alpha } \\
(\mathrm{pCi} / \mathrm{L})^{\mathrm{b}}\end{array}$ & $\underset{(\mu g / L)}{\text { As }}$ & $\underset{(\mu \mathrm{Ba} / \mathrm{L})}{\mathrm{Ba}}$ & $\underset{(\text { pCi } \mathbf{B} / \mathbf{L})^{\mathbf{b}}}{\text { Beta }}$ & $\underset{(\mu g / L)}{\mathrm{Ca}}$ & $\underset{(\mu g / L)}{C d}$ & $\underset{\text { (pDhos/cm) }}{\text { CDT }}$ & $\underset{(\mu g / L)}{C 1}$ \\
\hline Ground Vater & & & & & • & & & & & & \\
\hline $\begin{array}{l}1-9 S A \\
10-19 N \\
11-12 N A \\
11-1 S \\
13-16 N A \\
14-13 N A \\
5-12 N A \\
8-4 S \\
\text { GJ84-04 } \\
\text { GJ84-09 } \\
\text { GJ84-09 (Dup) } \\
\text { GJ84-10 } \\
\text { GJ87-15 }\end{array}$ & $\begin{array}{l}\text { NBA-379 } \\
\text { NBA-394 } \\
\text { NBA-385 } \\
\text { NBA-382 } \\
\text { NBA-395 } \\
\text { NBA-393 } \\
\text { NBA-378 } \\
\text { NBA }-381 \\
\text { NBA-390 } \\
\text { NBA-376 } \\
\text { NBA-377 } \\
\text { NBA-451 } \\
\text { NBA }-380\end{array}$ & $\begin{array}{l}12 / 15 / 1992 \\
12 / 18 / 1992 \\
12 / 16 / 1992 \\
12 / 15 / 1992 \\
12 / 18 / 1992 \\
12 / 18 / 1992 \\
12 / 15 / 1992 \\
12 / 15 / 1992 \\
12 / 17 / 1992 \\
12 / 14 / 1992 \\
12 / 14 / 1992 \\
12 / 14 / 1992 \\
12 / 15 / 1992\end{array}$ & $\begin{array}{l}249 \\
493 \\
343 \\
248 \\
575 \\
435 \\
327 \\
279 \\
315 \\
247 \\
247 \\
170 \\
374\end{array}$ & $\begin{array}{r}<40 \\
900 \\
240 \\
480 \\
600 \\
1000 \\
<70 \\
780 \\
630 \\
<50 \\
<50 \\
<60 \\
560\end{array}$ & $\begin{array}{r}<2.0 \\
<20.0 \\
43.5 \\
<2.0 \\
-3.4 \\
11.7 \\
<2.0 \\
<2.0 \\
<20.0 \\
<2.0 \\
<2.0 \\
<2.0 \\
81.3\end{array}$ & $\begin{array}{l}\sim 13.0 \\
\sim 12.6 \\
\sim-21.0 \\
\sim 12.7 \\
-16.2 \\
-16.3 \\
\sim 13.3 \\
\sim 19.0 \\
\sim 18.0 \\
\sim 12.2 \\
\sim 12.0 \\
\sim 6.7 \\
\sim 21.9\end{array}$ & $\begin{array}{r}90 \\
400 \\
80 \\
240 \\
320 \\
480 \\
<70 \\
320 \\
220 \\
<50 \\
<50 \\
<50 \\
180\end{array}$ & $\begin{array}{r}104000 \\
523000 \\
339000 \\
68500 \\
415000 \\
443000 \\
292000 \\
330000 \\
187000 \\
128000 \\
126000 \\
140000 \\
339000\end{array}$ & $\begin{array}{l}<1.0 \\
<1.0 \\
<1.0 \\
<1.0 \\
<1.0 \\
<1.0 \\
<1.0 \\
<1.0 \\
<1.0 \\
<1.0 \\
<1.0 \\
<1.0 \\
<1.0\end{array}$ & $\begin{array}{l}1915 \\
5170 \\
3741 \\
1628 \\
9200 \\
4440 \\
3100 \\
3240 \\
3880 \\
2390 \\
2390 \\
2600 \\
3390\end{array}$ & $\begin{array}{r}18700 \\
613000 \\
198000 \\
23700 \\
218000 \\
178000 \\
172000 \\
126000 \\
105000 \\
46200 \\
46700 \\
96100 \\
156000\end{array}$ \\
\hline \multicolumn{12}{|l|}{ Surface Water } \\
\hline $\begin{array}{l}\text { Lower Gunnison } \\
\text { Middle Gunnison } \\
\text { North Pond } \\
\text { South Pond } \\
\text { South Pond (Dup) } \\
\text { Upper Gunni son } \\
\text { Upper Mid Gunnison }\end{array}$ & $\begin{array}{l}\text { NBA-392 } \\
\text { NBA-391 } \\
\text { NBA-386 } \\
\text { NEA }-387 \\
\text { NBA-388 } \\
\text { NBA-383 } \\
\text { NBA-384 }\end{array}$ & $\begin{array}{l}12 / 17 / 1992 \\
12 / 17 / 1992 \\
12 / 16 / 1992 \\
12 / 17 / 1992 \\
12 / 17 / 1992 \\
12 / 16 / 1992 \\
12 / 16 / 1992\end{array}$ & $\begin{array}{r}175 \\
166 \\
240 \\
95 \\
95 \\
150 \\
161\end{array}$ & $\begin{array}{r}<30 \\
<20 \\
250 \\
420 \\
490 \\
<20 \\
20\end{array}$ & $\begin{array}{l}<2.0 \\
<2.0 \\
<2.0 \\
13.8 \\
11.6 \\
<2.0 \\
<2.0\end{array}$ & $\begin{array}{l}-36.8 \\
-36.7 \\
-10.6 \\
-13.8 \\
-14.4 \\
-38.5 \\
-38.1\end{array}$ & $\begin{array}{r}<20 \\
<20 \\
<110 \\
140 \\
160 \\
<20 \\
<20\end{array}$ & $\begin{array}{l}121000 \\
117000 \\
347000 \\
337000 \\
355000 \\
123000 \\
123000\end{array}$ & $\begin{array}{l}<1.0 \\
<1.0 \\
<1.0 \\
<1.0 \\
<1.0 \\
<1.0 \\
<1.0\end{array}$ & $\begin{array}{r}1358 \\
948 \\
5250 \\
3410 \\
3410 \\
1281 \\
1278\end{array}$ & $\begin{array}{r}10600 \\
10600 \\
371000 \\
167000 \\
167000 \\
10800 \\
11000\end{array}$ \\
\hline \multicolumn{12}{|l|}{$Q A / Q C$} \\
\hline Equipment Blank & NBA-389 & $12 / 17 / 1992$ & No Data & $<6$ & $<2.0$ & $<5.0$ & $<10$ & $\sim 297$ & $<1.0$ & No Data & $\sim 21.7$ \\
\hline
\end{tabular}

aA "<" indicates that the maximum concentration was below detection limits (number shown is detection limit). A " $"$ indicates an approximate value (the value was outside the limits for which the instrument was calibrated).

bThe values listed multiplied by $10^{-9}$ will result in $\mu \mathrm{Ci} / \mathrm{mL}$. 
Table A 21 (contimued) Water (hemistry Data for Grand Junction, December 14 through December 18, $1992^{a}$

\begin{tabular}{|c|c|c|c|c|c|c|c|c|c|c|c|}
\hline $\begin{array}{l}\text { Sample } \\
\text { Iocation }\end{array}$ & $\begin{array}{l}\text { licket } \\
\text { Muntser }\end{array}$ & $\begin{array}{l}\text { Sample } \\
\text { Date }\end{array}$ & $\underset{(\mu / /)}{C r}$ & $\begin{array}{c}\text { Fe } \\
(\mu \mathrm{g} / L)\end{array}$ & $\begin{array}{c}\mathrm{H}_{2} \mathrm{O} \text { Depth } \\
\text { (f eet) }\end{array}$ & $\underset{(\mu \rho g / L)}{K}$ & $\underset{(\mu \mathrm{g} / \mathrm{L})}{\mathbf{M g}}$ & $\underset{(\mu \mathrm{g} / \mathrm{L})}{\operatorname{mn}}$ & $\underset{(\mu g / L)}{M o}$ & $\underset{(\mu a / L)}{M a}$ & $\underset{(\mu g / L)}{M_{3}}$ \\
\hline \multicolumn{12}{|l|}{ Ground Vater } \\
\hline $\begin{array}{l}1-95 A \\
10-19 \mathrm{~N} \\
11-12 N A \\
11-15 \\
13-16 N A \\
14-13 N A \\
5-12 N A \\
8-45 \\
\text { GJ84-04 } \\
\text { G.J84-09 } \\
\text { GJ84-09 (Dup) } \\
\text { GJ84-10 } \\
\text { G.J87-15 }\end{array}$ & $\begin{array}{l}\text { NBA } 379 \\
\text { NBA- } 394 \\
\text { NBA } 385 \\
\text { NBA- } 382 \\
\text { NBA- } 395 \\
\text { NBA- } 393 \\
\text { NBA- } 378 \\
\text { NBA } 381 \\
\text { NBA }-390 \\
\text { NBA } 376 \\
\text { NBA- } 377 \\
\text { NBA- } 451 \\
\text { NBA- } 380\end{array}$ & $\begin{array}{l}12 / 15 / 1992 \\
12 / 18 / 1992 \\
12 / 16 / 1992 \\
12 / 15 / 1992 \\
12 / 18 / 1992 \\
12 / 18 / 1992 \\
12 / 15 / 1992 \\
12 / 15 / 1992 \\
12 / 17 / 1992 \\
12 / 14 / 1992 \\
12 / 14 / 1992 \\
12 / 14 / 1992 \\
12 / 15 / 1992\end{array}$ & $\begin{array}{l}<40 \\
<4.0 \\
<4.0 \\
<4.0 \\
<4.0 \\
<4.0 \\
<4.0 \\
<4.0 \\
<4.0 \\
<4.0 \\
<4.0 \\
<4.0 \\
<4.0\end{array}$ & $\begin{array}{c}-13.1 \\
387 \\
<5.0 \\
<5.0 \\
1620 \\
<5.0 \\
<5.0 \\
-6.2 \\
-18.3 \\
128 \\
120 \\
<5.0 \\
<5.0\end{array}$ & $\begin{array}{r}13.31 \\
4.67 \\
5.69 \\
17.04 \\
13.22 \\
6.06 \\
10.00 \\
9.12 \\
9.34 \\
20.95 \\
20.95 \\
33.46 \\
7.98\end{array}$ & $\begin{array}{r}6040 \\
23100 \\
11600 \\
6350 \\
20000 \\
22100 \\
6210 \\
10300 \\
13300 \\
7970 \\
8040 \\
5280 \\
16800\end{array}$ & $\begin{array}{r}16600 \\
310000 \\
101000 \\
27400 \\
112000 \\
88500 \\
112000 \\
102000 \\
52400 \\
20300 \\
19900 \\
32400 \\
78100\end{array}$ & $\begin{array}{c}971 \\
5370 \\
1160 \\
36.9 \\
7140 \\
5630 \\
577 \\
1290 \\
2460 \\
223 \\
209 \\
465 \\
3940\end{array}$ & $\begin{array}{l}<27.0 \\
194 \\
<27.0 \\
210 \\
204 \\
250 \\
<27.0 \\
167 \\
270 \\
<27.0 \\
<27.0 \\
<27.0 \\
127\end{array}$ & $\begin{array}{r}318000 \\
1580000 \\
449000 \\
247000 \\
743000 \\
561000 \\
315000 \\
301000 \\
665000 \\
408000 \\
406000 \\
442000 \\
405000\end{array}$ & $\begin{array}{c}\sim 62.1 \\
-288 \\
14700 \\
-205 \\
-303 \\
-499 \\
-298 \\
159000 \\
\sim 155 \\
-124 \\
\sim 83.1 \\
\sim 247 \\
1410\end{array}$ \\
\hline \multicolumn{12}{|l|}{ Surface Vater } \\
\hline $\begin{array}{l}\text { Lower Gunnison } \\
\text { Middle Gunnison } \\
\text { North Pond } \\
\text { South Pond } \\
\text { South Pond (Dup) } \\
\text { Upper Gunnison } \\
\text { Upper Mid Gunn ison }\end{array}$ & $\begin{array}{l}\text { NBA }-392 \\
\text { NBA-391 } \\
\text { NBA-385 } \\
\text { NBA-387 } \\
\text { NBA-388 } \\
\text { NBA-383 } \\
\text { NBA }-384\end{array}$ & $\begin{array}{l}12 / 17 / 1992 \\
12 / 17 / 1992 \\
12 / 16 / 1992 \\
12 / 17 / 1992 \\
12 / 17 / 1992 \\
12 / 16 / 1992 \\
12 / 16 / 1992\end{array}$ & $\begin{array}{l}<4.0 \\
<4.0 \\
<4.0 \\
<4.0 \\
<4.0 \\
<4.0 \\
<4.0\end{array}$ & $\begin{array}{l}<5.0 \\
<5.0 \\
-8.6 \\
<5.0 \\
<5.0 \\
<5.0 \\
<5.0\end{array}$ & $\begin{array}{l}\text { No Data } \\
\text { No Data } \\
\text { No Data } \\
\text { No Data } \\
\text { No Data } \\
\text { No Data } \\
\text { No Data }\end{array}$ & $\begin{array}{l}\sim 3010 \\
\sim 3420 \\
23100 \\
\text { No Data } \\
16000 \\
\sim 3330 \\
\sim 3250\end{array}$ & $\begin{array}{r}48500 \\
47200 \\
212000 \\
73300 \\
74000 \\
47900 \\
47300\end{array}$ & $\begin{array}{c}53.9 \\
54.2 \\
45.1 \\
165 \\
166 \\
56.7 \\
64.3\end{array}$ & $\begin{array}{l}<27.0 \\
<27.0 \\
-32.2 \\
108 \\
122 \\
<27.0 \\
<27.0\end{array}$ & $\begin{array}{r}78500 \\
77900 \\
927000 \\
382000 \\
394000 \\
78100 \\
79800\end{array}$ & $\begin{array}{r}5120 \\
5180 \\
1140 \\
17200 \\
17100 \\
5300 \\
5340\end{array}$ \\
\hline \multicolumn{12}{|l|}{ QA/OC } \\
\hline Equipment Blank & NBA-389 & $12 / 17 / 1992$ & $<4.0$ & $<5.0$ & No Data & $<1490$ & -39.4 & $\sim 1.1$ & $<27.0$ & $<52.0$ & -26.7 \\
\hline
\end{tabular}

$a_{A}$ "<" indicates that the maximum concentration was below detection limits (number shown is detection 1 imit). A " $"$ indicates an approximate value (the value was outsido the limits for which the instrument was calibrated). 
Table A-21 (continued). Water Chemistry Data for Grand Junction, December 14 through December 18, 1992a

\begin{tabular}{|c|c|c|c|c|c|c|c|c|c|c|c|}
\hline $\begin{array}{l}\text { Sample } \\
\text { Location }\end{array}$ & $\begin{array}{l}\text { Ticket } \\
\text { Number }\end{array}$ & $\begin{array}{c}\text { Sample } \\
\text { Date }\end{array}$ & $\underset{(\mu \mathrm{gb} / \mathrm{L})}{\mathrm{Pb}}$ & $\mathbf{p H}$ & $\begin{array}{l}R a-226 \\
(\mathrm{pCi} / \mathrm{L})^{b}\end{array}$ & $\begin{array}{c}\mathrm{Ra}-228 \\
(\mathrm{pCi} / \mathrm{L})^{\mathrm{b}}\end{array}$ & $\begin{array}{c}\text { Se } \\
(\mu \mathrm{g} / \mathrm{L})\end{array}$ & $\begin{array}{l}\mathrm{SO}_{4} \\
(\mu \mathrm{g} / \mathrm{L})\end{array}$ & $\begin{array}{l}\text { TOS } \\
(\mathrm{mg} / \mathrm{L})\end{array}$ & $\begin{array}{c}\text { Temp } \\
(\operatorname{Deg} C)\end{array}$ & $\begin{array}{c}\text { Th-230 } \\
(\mathrm{pCi} / \mathrm{L})^{b}\end{array}$ \\
\hline Ground Water & & . & & & & & & & & & \\
\hline $\begin{array}{l}1-9 S A \\
10-9 N \\
11-\not N A \\
11-1 S \\
13-16 N A \\
14-13 N A \\
5-12 N A \\
8-4 S \\
\text { GJ84-04 } \\
\text { GJ84-09 } \\
\text { GJ84-09 (Dup) } \\
\text { GJ84-10 } \\
\text { GJ87-15 }\end{array}$ & $\begin{array}{l}\text { NBA-379 } \\
\text { NBA-394 } \\
\text { NBA-385 } \\
\text { NBA-382 } \\
\text { NBA-395 } \\
\text { NBA-393 } \\
\text { NBA-378 } \\
\text { NBA-381 } \\
\text { NBA-390 } \\
\text { NBA-376 } \\
\text { NBA-377 } \\
\text { NBA-451 } \\
\text { NBA-380 }\end{array}$ & $\begin{array}{l}12 / 15 / 1992 \\
12 / 18 / 1992 \\
12 / 16 / 1992 \\
12 / 15 / 1992 \\
12 / 18 / 1992 \\
12 / 18 / 1992 \\
12 / 15 / 1992 \\
12 / 15 / 1992 \\
12 / 17 / 1992 \\
12 / 14 / 1992 \\
12 / 14 / 1992 \\
12 / 14 / 1992 \\
12 / 15 / 1992\end{array}$ & $\begin{array}{l}<1.0 \\
<1.0 \\
<1.0 \\
57.1 \\
<1.0 \\
<1.0 \\
<1.0 \\
<1.0 \\
<1.0 \\
<1.0 \\
<1.0 \\
<1.0 \\
<1.0\end{array}$ & $\begin{array}{l}7.62 \\
6.87 \\
7.08 \\
7.36 \\
7.12 \\
6.85 \\
6.87 \\
7.15 \\
6.89 \\
7.17 \\
7.17 \\
7.39 \\
6.79\end{array}$ & $\begin{array}{r}<0.1 \\
0.1 \\
<0.3 \\
<0.1 \\
<0.1 \\
0.1 \\
<0.1 \\
0.3 \\
<0.1 \\
<0.1 \\
<0.1 \\
<0.1 \\
<0.1\end{array}$ & $\begin{array}{l}<2 \\
<2 \\
<2 \\
<2 \\
<2 \\
<2 \\
<1 \\
<3 \\
<2 \\
<2 \\
<2 \\
<3 \\
<2\end{array}$ & $\begin{array}{r}<2.0 \\
<20.0 \\
54.5 \\
<2.0 \\
\sim 2.1 \\
\sim 2.8 \\
\sim 3.0 \\
91.7 \\
<2.0 \\
<2.0 \\
<2.0 \\
\sim 2.2 \\
10.1\end{array}$ & $\begin{array}{r}711000 \\
4300000 \\
1520000 \\
507000 \\
2220000 \\
1910000 \\
1290000 \\
1220000 \\
1550000 \\
908000 \\
917000 \\
1050000 \\
1420000\end{array}$ & $\begin{array}{l}1410 \\
8100 \\
2770 \\
1010 \\
4300 \\
3730 \\
2590 \\
2590 \\
2920 \\
1750 \\
1730 \\
1950 \\
2820\end{array}$ & $\begin{array}{l}16.3 \\
15.5 \\
15.7 \\
15.5 \\
13.5 \\
15.5 \\
14.9 \\
14.7 \\
14.9 \\
14.9 \\
14.9 \\
14.7 \\
16.3\end{array}$ & $\begin{array}{r}<0.3 \\
1.1 \\
<0.3 \\
<0.4 \\
<0.3 \\
<0.8 \\
<0.3 \\
<0.3 \\
3.2 \\
<0.3 \\
<0.3 \\
<0.3 \\
<0.3\end{array}$ \\
\hline \multicolumn{12}{|l|}{ Surface Mater } \\
\hline $\begin{array}{l}\text { Lower Gunnison } \\
\text { Middle Gunnison } \\
\text { North Pond } \\
\text { South Pond } \\
\text { South Pond (Dup) } \\
\text { Upper Gunnison } \\
\text { Upper Mid Gunnison }\end{array}$ & $\begin{array}{l}\text { NBA-392 } \\
\text { NBA-391 } \\
\text { NBA-386 } \\
\text { NBA-387 } \\
\text { NBA-388 } \\
\text { NBA-383 } \\
\text { NBA-384 }\end{array}$ & $\begin{array}{l}12 / 17 / 1992 \\
12 / 17 / 1992 \\
12 / 16 / 1992 \\
12 / 17 / 1992 \\
12 / 17 / 1992 \\
12 / 16 / 1992 \\
12 / 16 / 1992\end{array}$ & $\begin{aligned}<1.0 \\
<1.0 \\
<1.0 \\
<1.0 \\
<1.0 \\
5.5 \\
<1.0\end{aligned}$ & $\begin{array}{l}8.65 \\
8.74 \\
6.86 \\
7.69 \\
7.69 \\
8.22 \\
7.65\end{array}$ & $\begin{array}{r}0.1 \\
<0.1 \\
12.3 \\
<0.1 \\
<0.1 \\
<0.2 \\
0.1\end{array}$ & $\begin{array}{l}<2 \\
<2 \\
<4 \\
<2 \\
<3 \\
<4 \\
<2\end{array}$ & $\begin{array}{r}6.0 \\
5.7 \\
-3.8 \\
-3.7 \\
-3.5 \\
9.6 \\
7.8\end{array}$ & $\begin{array}{r}435000 \\
434000 \\
2790000 \\
1560000 \\
1560000 \\
444000 \\
447000\end{array}$ & $\begin{array}{r}919 \\
892 \\
5120 \\
2870 \\
2860 \\
902 \\
914\end{array}$ & $\begin{array}{l}0.2 \\
0.4 \\
3.4 \\
2.0 \\
2.0 \\
1.0 \\
2.0\end{array}$ & $\begin{array}{c}<0.3 \\
<0.3 \\
5.0 \\
<0.6 \\
<0.5 \\
0.70 \\
<0.3\end{array}$ \\
\hline \multicolumn{12}{|l|}{$Q A / Q C$} \\
\hline Equipment Blank & NBA-389 & $12 / 17 / 1992$ & $<1.0$ & No Data & $<0.1$ & $<2$ & $<2.0$ & $<85.0$ & 214 & No Data & $<0.3$ \\
\hline
\end{tabular}

$a_{A} "<"$ indicates that the maximum concentration was below detection limits (number shown is detection limit). A " " indicates an approximate value (the value was outside the limits for which the instrument was calibrated).

bThe values 1 isted multiplied by $10^{-9}$ will result in $\mu \mathrm{Ci} / \mathrm{mL}$. 
Table A-21 (cont inued). Water Chemistry Data for Grand Junction, December 14 through December 18, $1992^{a}$

\begin{tabular}{|c|c|c|c|c|c|c|c|}
\hline $\begin{array}{l}\text { Sample } \\
\text { Location }\end{array}$ & $\begin{array}{l}\text { Ticket } \\
\text { Number }\end{array}$ & $\begin{array}{l}\text { Sample } \\
\text { Date }\end{array}$ & $\begin{array}{c}\text { Th-232 } \\
(\mathrm{pCi} / \mathrm{L})^{\mathrm{b}}\end{array}$ & $\begin{array}{c}\mathrm{TOC} \\
(\mathrm{mg} / \mathrm{L})\end{array}$ & $\underset{(p C i / L)^{b}}{U-234}$ & $\begin{array}{c}U-238 \\
(\mathrm{pCi} / L)^{b}\end{array}$ & $\underset{(\mu g / L)}{V}$ \\
\hline \multicolumn{8}{|l|}{ Ground Mater } \\
\hline $\begin{array}{l}1-9 S A \\
10-19 N \\
11-12 N A \\
11-15 \\
13-16 N A \\
14-13 N A \\
5-12 N A \\
8-4 S \\
\text { GJ84-04 } \\
\text { GJ84-09 } \\
\text { GJ84-09 (Dup) } \\
\text { GJ84-10 } \\
\text { GJ87-15 }\end{array}$ & $\begin{array}{l}\text { NBA-379 } \\
\text { NBA-394 } \\
\text { NBA-385 } \\
\text { NBA-382 } \\
\text { NBA-395 } \\
\text { NBA-393 } \\
\text { NBA-378 } \\
\text { NBA-381 } \\
\text { NBA-390 } \\
\text { NBA-376 } \\
\text { NBA-377 } \\
\text { NBA-451 } \\
\text { NBA }-380\end{array}$ & $\begin{array}{l}12 / 15 / 1992 \\
12 / 18 / 1992 \\
12 / 16 / 1992 \\
12 / 15 / 1992 \\
12 / 18 / 1992 \\
12 / 18 / 1992 \\
12 / 15 / 1992 \\
12 / 15 / 1992 \\
12 / 17 / 1992 \\
12 / 14 / 1992 \\
12 / 14 / 1992 \\
12 / 14 / 1992 \\
12 / 15 / 1992\end{array}$ & $\begin{array}{r}<0.3 \\
0.8 \\
<0.3 \\
0.5 \\
<0.3 \\
<0.7 \\
<0.3 \\
<0.3 \\
1.1 \\
<0.3 \\
<0.3 \\
<0.3 \\
<0.3\end{array}$ & $\begin{array}{r}1.2 \\
15.2 \\
6.2 \\
5.9 \\
11.2 \\
8.5 \\
3.7 \\
5.3 \\
5.6 \\
2.0 \\
2.0 \\
1.4 \\
6.4\end{array}$ & $\begin{array}{r}11.22 \\
434.56 \\
115.05 \\
253.78 \\
323.40 \\
470.48 \\
22.75 \\
281.01 \\
303.78 \\
7.84 \\
7.68 \\
8.60 \\
223.83\end{array}$ & $\begin{array}{r}7.35 \\
410.15 \\
104.29 \\
255.35 \\
320.13 \\
462.38 \\
14.60 \\
281.06 \\
297.42 \\
4.06 \\
3.95 \\
3.72 \\
225.69\end{array}$ & $\begin{array}{r}<9.0 \\
<9.0 \\
160 \\
<9.0 \\
\sim 21.7 \\
\sim 22.2 \\
<9.0 \\
<9.0 \\
\sim 28.8 \\
<9.0 \\
<9.0 \\
<9.0 \\
227\end{array}$ \\
\hline \multicolumn{8}{|l|}{ Surface Mater } \\
\hline $\begin{array}{l}\text { Lower Gunnison } \\
\text { Middle Gunnison } \\
\text { North Pond } \\
\text { South Pond } \\
\text { South Pond (Dup) } \\
\text { Upper Gunnison } \\
\text { Upper Mid Gunnison }\end{array}$ & $\begin{array}{l}\text { NBA-392 } \\
\text { NBA-391 } \\
\text { NBA-386 } \\
\text { NBA-387 } \\
\text { NBA-388 } \\
\text { NBA-383 } \\
\text { NBA-384 }\end{array}$ & $\begin{array}{l}12 / 17 / 1992 \\
12 / 17 / 1992 \\
12 / 16 / 1992 \\
12 / 17 / 1992 \\
12 / 17 / 1992 \\
12 / 16 / 1992 \\
12 / 16 / 1992\end{array}$ & $\begin{array}{c}<0.3 \\
<0.3 \\
4.6 \\
<0.5 \\
<0.3 \\
0.50 \\
<0.3\end{array}$ & $\begin{array}{r}5.1 \\
4.8 \\
21.8 \\
8.7 \\
8.3 \\
5.1 \\
4.6\end{array}$ & $\begin{array}{r}5.79 \\
6.30 \\
164.79 \\
199.17 \\
203.47 \\
6.34 \\
8.30\end{array}$ & $\begin{array}{r}4.12 \\
4.19 \\
149.48 \\
201.57 \\
198.91 \\
4.08 \\
6.09\end{array}$ & $\begin{array}{l}<9.0 \\
<9.0 \\
<9.0 \\
50.5 \\
53.4 \\
<9.0 \\
<9.0\end{array}$ \\
\hline \multicolumn{8}{|l|}{$Q A / Q C$} \\
\hline Equipment Blank & NBA-3B9 & $12 / 17 / 1992$ & $<0.3$ & No Data & 0.54 & 0.45 & $<9.0$ \\
\hline
\end{tabular}

$a_{A}$ "<" indicates that the maximum concentration was below detection limits (number shown is detection limit). A " $"$ " indicates an approximate value (the value was outside the limits for which the instrument was calibrated).

bThe values listed multiplied by $10^{-9}$ will result in $\mu \mathrm{Ci} / \mathrm{mL}$. 
Table A-22. Target Compound List of Organic Constituents Included in Analysis of Ground Water at the GJPO

CAS Number Constituent

Reporting Limit $(\mu \mathrm{g} / \mathrm{L})$

\section{Volatile Organics}

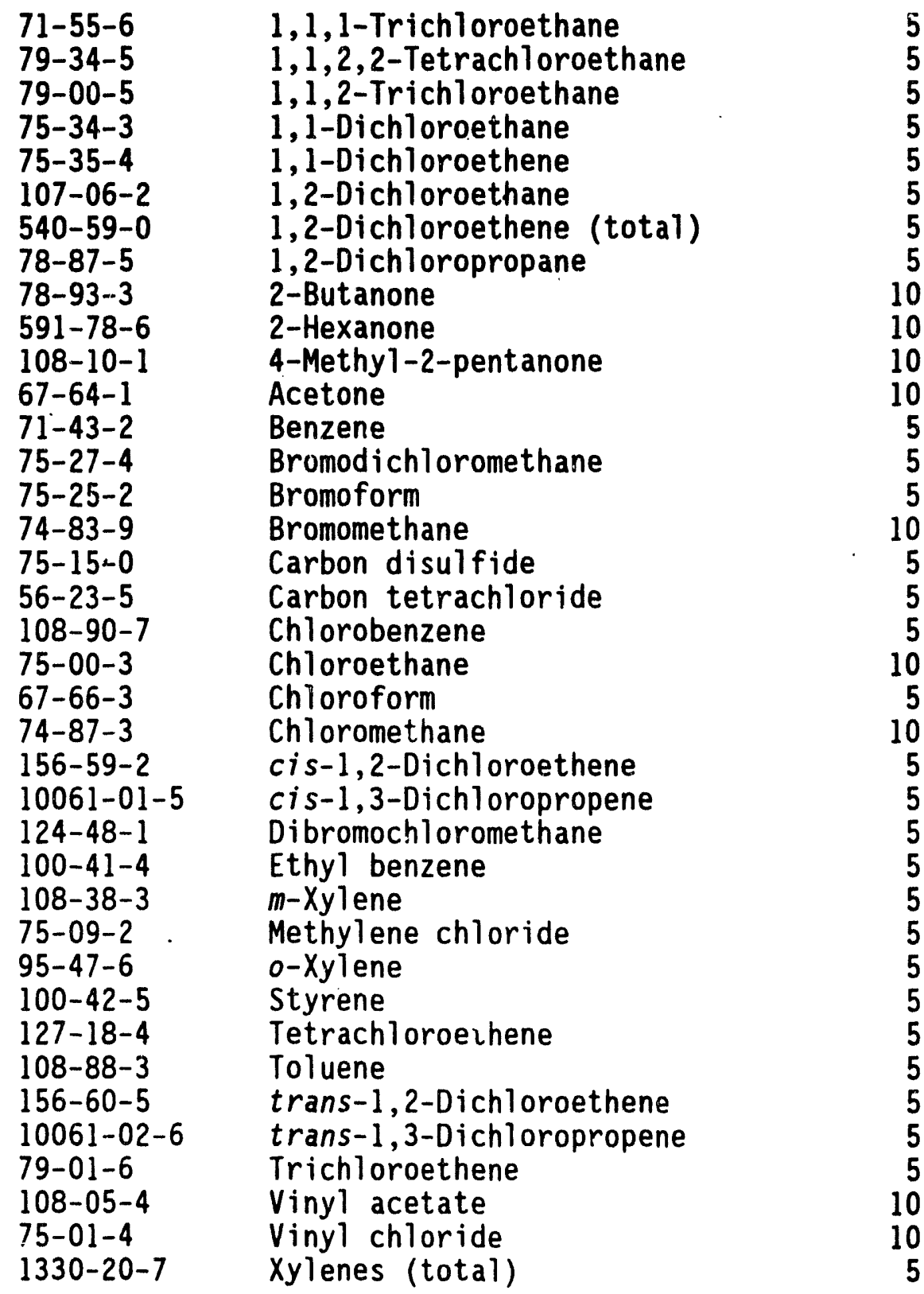


Table A-22 (continued). Target Compound List of Organic Constituents Included in Analysis of Ground Water at the GJPO

CAS Number Const tuent

Reporting Limit $(\mu \mathrm{g} / \mathrm{L})$

Herbicides

$\begin{array}{llr}93-76-5 & 2,4,5-T & 0.20 \\ 93-72-1 & 2,4,5-T P \text { (Silvex) } & 0.17 \\ 94-75-7 & 2,4-D & 1.2 \\ 94-82-6 & 2,4-D B & 0.91 \\ 75-99-0 & \text { Dalapon } & 5.8 \\ 120-36-5 & \text { Dichloroprop } & 0.65 \\ 94-74-6 & \text { MCPA } & 249 \\ 7085-19-0 & \text { MCPP } & 192\end{array}$

Pesticides

\begin{tabular}{|c|c|c|}
\hline $\begin{array}{l}72-54-8 \\
72-55-9 \\
50-29-3 \\
309-00-2 \\
319-84-6 \\
5103-71-9 \\
12674-11-2 \\
11104-28-2 \\
11141-16-5 \\
53469-21-9 \\
12672-29-6 \\
11097-69-1 \\
11096-82-5 \\
319-85-7 \\
319-86-8 \\
60-57-1 \\
959-98-8 \\
33213-65-9 \\
1031-07-8 \\
72-20-8 \\
7421-93-4 \\
53494-70-5 \\
58-89-9 \\
5103-74-2 \\
76-44-8 \\
1024-57-3 \\
72-43-5 \\
8001-35-2\end{array}$ & $\begin{array}{l}4,4 \text { '-DDD } \\
4,4 \text { '-DDE } \\
4,4 \text { '-DDT } \\
\text { Aldrin } \\
\text { alpha-BHC } \\
\text { alpha-Chlordane } \\
\text { Aroclor-1016 } \\
\text { Aroclor-1221 } \\
\text { Aroclor-1232 } \\
\text { Aroclor-1242 } \\
\text { Aroclor-1248 } \\
\text { Aroclor-1254 } \\
\text { Aroclor-1260 } \\
\text { beta-BHC } \\
\text { delta-BHC } \\
\text { Dieldrin } \\
\text { Endosulfan I } \\
\text { Endosulfan II } \\
\text { Endosulfan sulfate } \\
\text { Endrin } \\
\text { Endrin aldehyde } \\
\text { Endrin ketone } \\
\text { gamma-BHC (Lindane) } \\
\text { gamma-Chlordane } \\
\text { Heptachlor } \\
\text { Heptachlor epoxide } \\
\text { Methoxychlor } \\
\text { Toxaphene }\end{array}$ & $\begin{array}{l}0.10 \\
0.10 \\
0.10 \\
0.05 \\
0.05 \\
0.05 \\
0.5 \\
0.5 \\
0.5 \\
0.5 \\
0.5 \\
1.0 \\
1.0 \\
0.05 \\
0.05 \\
0.10 \\
0.05 \\
0.10 \\
0.10 \\
0.10 \\
0.10 \\
0.10 \\
0.05 \\
0.05 \\
0.05 \\
0.05 \\
0.5 \\
1.0\end{array}$ \\
\hline
\end{tabular}


Table A-22 (continued). Target Compound List of Organic Constituents Included in Analysis of Ground Water at the GJPO

CAS Number Constituent

Reporting Limit $(\mu \mathrm{g} / \mathrm{L})$

\section{Semivolatile Organics}

\begin{tabular}{|c|c|}
\hline $\begin{array}{l}120-82-1 \\
95-50-1 \\
541-73-1 \\
106-46-7 \\
108-60-1 \\
95-95-4 \\
88-06-2 \\
120-83-2 \\
105-67-9 \\
51-28-5 \\
121-14-2 \\
606-20-2 \\
91-58-7 \\
95-57-8 \\
91-57-6 \\
95-48-7 \\
88-74-4 \\
88-75-5 \\
91-94-1 \\
99-09-2 \\
534-52-1 \\
101-55-3 \\
59-50-7 \\
106-47-8 \\
7005-72-3 \\
106-44-5 \\
100-01-6 \\
100-02-7 \\
83-32-9 \\
208-96-8 \\
120-12-7 \\
56-55-3 \\
50-32-8 \\
205-99-2 \\
191-24-2 \\
207-08-9 \\
65-85-0 \\
100-51-6 \\
111-91-1 \\
111-44-4 \\
117-81-7 \\
85-68-7 \\
218-01-9 \\
\end{array}$ & $\begin{array}{l}\text { 1,2,4-Trichlorobenzene } \\
\text { 1,2-Dichlorobenzene } \\
\text { 1,3-Dichlorobenzene } \\
\text { 1,4-Dichlorobenzene } \\
\text { 2,2-0xybis(1-chloropropane) } \\
\text { 2,4,5-Trichlorophenol } \\
\text { 2,4,6-Trichlorophenol } \\
\text { 2,4-Dichlorophenol } \\
\text { 2,4-Dimethylphenol } \\
\text { 2,4-Dinitrophenol } \\
\text { 2,4-Dinitrotoluene } \\
\text { 2,6-Dinitrotoluene } \\
\text { 2-Chloronaphthalene } \\
\text { 2-Chlorophenol } \\
\text { 2-Methylnaphthalene } \\
\text { 2-Methylphenol } \\
\text { 2-Nitroaniline } \\
\text { 2-Nitrophenol } \\
\text { 3,3-Dichlorobenzidine } \\
\text { 3-Nitroaniline } \\
\text { 4,6-Dinitro-2-methylphenol } \\
\text { 4-Bromophenyl-phenylether } \\
\text { 4-Chloro-3-methylphenol } \\
\text { 4-Chloroaniline } \\
\text { 4-Chlorophenyl phenyl ether } \\
\text { 4-Methylphenol } \\
\text { 4-Nitroaniline } \\
\text { 4-Nitrophenol } \\
\text { Acenaphthene } \\
\text { Acenaphthylene } \\
\text { Anthracene } \\
\text { Benzo(a)anthracene } \\
\text { Benzo(a)pyrene } \\
\text { Benzo(b) fluoranthene } \\
\text { Benzo(g,h,i)perylene } \\
\text { Benzo(k) fluoranthene } \\
\text { Benzoic acid } \\
\text { Benzyl alcohol } \\
\text { Bis(2-chloroethoxy)methare } \\
\text { Bis (2-chloroethyl)ether } \\
\text { Bis(2-ethylhexyl)phthalate } \\
\text { Butyl benzyl phthalate } \\
\text { Chrysene } \\
\end{array}$ \\
\hline
\end{tabular}


Table A-22 (continued). Target Compound List of Organic Colstituents Included in Analysis of Ground Water at the GJPO

CAS Number Constituent

Reporting Limit

$(\mu g / L)$

\section{Semivolatile Organics}

$\begin{array}{lll}84-74-2 & \text { Di-n-butylphthalate } & 10 \\ 117-84-0 & \text { Di-n-octylphthalate } & 10 \\ 53-70-3 & \text { Dibenzo(a,h)anthracene } & 10 \\ 132-64-9 . & \text { Dibenzofuran } & 10 \\ 84-66-2 & \text { Diethylphthalate } & 10 \\ 131-11-3 & \text { Dimethylphthalate } & 10 \\ 206-44-0 & \text { Fluoranthene } & 10 \\ 86-73-7 & \text { Fluorene } & 10 \\ 118-74-1 & \text { Hexachlorobenzene } & 10 \\ 87-68-3 & \text { Hexachlorobutadiene } & 10 \\ 77-47-4 & \text { Hexachlorocyclopentadiene } & 10 \\ 67-72-1 & \text { Hexachloroethane } & 10 \\ 193-39-5 & \text { Indeno(1,2,3-cd)pyrene } & 10 \\ 78-59-1 & \text { Isophorone } & 10 \\ 621-64-7 & \text { N-Nitroso-di-n-dipropylamine } & 10 \\ 86-30-6 & \text { N-Nitrosodiphenylamine } & 10 \\ 91-20-3 & \text { Naphthalene } & 10 \\ 98-95-3 & \text { Nitrobenzene } & 10 \\ 87-86-5 & \text { Pentachlorophenol } & 50 \\ 85-01-8 & \text { Phenanthrene } & 10 \\ 108-95-2 & \text { Phenol } & 10 \\ 129-00-0 & \text { Pyrene } & 10\end{array}$


Table A-23. Organic Constituents Observed in Samples Collected from Ground Water at the GJP0, March 16 through March 18, $1992^{2}, \mathrm{~b}$

\begin{tabular}{|c|c|c|c|c|c|c|c|c|c|c|}
\hline $\begin{array}{l}\text { Smple } \\
\text { Location }\end{array}$ & $\begin{array}{l}\text { Iicket } \\
\text { Number }\end{array}$ & $\begin{array}{l}\text { Sample } \\
\text { Date }\end{array}$ & $\begin{array}{l}112-95-8 c, d \\
(\mu g / L)\end{array}$ & $\begin{array}{l}117-81-7 c, e \\
(\mu / L)\end{array}$ & $\begin{array}{l}17302-32-8 C, d \\
(\mu g / L)\end{array}$ & $\begin{array}{l}544-76-3^{c, d} \\
(\mu g / L)\end{array}$ & $\begin{array}{l}\text { 62016-18-6c,d } \\
(\mu g / L)\end{array}$ & $\begin{array}{l}629-99-2^{c}, d \\
(\mu g / L)\end{array}$ & $\begin{array}{l}630-02-4 c, d \\
(p g / L)\end{array}$ & $\begin{array}{l}74-83-9 e, f \\
(\mu g / L)\end{array}$ \\
\hline \multicolumn{11}{|l|}{ Ground Water } \\
\hline $\begin{array}{l}1-9 \text { SA } \\
10-19 N \\
11-15 \\
13-16 N A \\
13-16 N A \text { (Dup) } \\
14-13 N A \\
14-6 N A \\
3-3 N A \\
5-12 N A \\
\text { GJ84-04 } \\
\text { GJ84-05 } \\
\text { GJ84-06 } \\
\text { GJ84-09 } \\
\text { GJ84-10 } \\
P-2 A \\
P-3 A \\
P-4 A \\
P-6\end{array}$ & $\begin{array}{l}\text { MLY Y-734 } \\
M L Y-684 \\
M L Y-682 \\
M L Y-728 \\
M L Y-729 \\
M L Y-730 \\
M L Y-683 \\
M L Y-736 \\
M L Y-737 \\
M L Y-731 \\
M L Y-733 \\
M L Y-690 \\
M L Y-735 \\
M L Y-727 \\
M L Y-688 \\
M L Y-685 \\
M L Y-689 \\
M L Y-686\end{array}$ & $\begin{array}{l}03 / 18 / 1992 \\
03 / 17 / 1992 \\
03 / 17 / 1992 \\
03 / 17 / 1992 \\
03 / 17 / 1992 \\
03 / 17 / 1992 \\
03 / 17 / 1992 \\
03 / 18 / 1992 \\
03 / 18 / 1992 \\
03 / 17 / 1992 \\
03 / 17 / 1992 \\
03 / 18 / 1992 \\
03 / 18 / 1992 \\
03 / 16 / 1992 \\
03 / 18 / 1992 \\
03 / 17 / 1992 \\
03 / 18 / 1992 \\
03 / 18 / 1992\end{array}$ & $\begin{array}{l}N g \\
N \\
N \\
N \\
N \\
N \\
N \\
-15 \\
N \\
N \\
N \\
N \\
N \\
N \\
N \\
N \\
N \\
N\end{array}$ & $\begin{array}{l}<10 \\
<10 \\
<10 \\
<10 \\
<10 \\
<10 \\
-6 \\
<10 \\
<10 \\
<10 \\
<10 \\
<10 \\
<10 \\
<10 \\
<10 \\
<10 \\
<10 \\
<10\end{array}$ & $\begin{array}{c}N \\
N \\
N \\
N \\
N \\
N \\
N \\
-12 \\
N \\
N \\
N \\
N \\
N \\
N \\
N \\
N \\
N \\
N\end{array}$ & $\begin{array}{l}N \\
N \\
N \\
N \\
N \\
N \\
-9 \\
N \\
N \\
N \\
N \\
N \\
N \\
N \\
N \\
N \\
N\end{array}$ & $\begin{array}{l}N \\
N \\
N \\
N \\
N \\
N \\
-5 \\
N \\
N \\
N \\
N \\
N \\
N \\
N \\
N \\
N \\
N\end{array}$ & $\begin{array}{l}N \\
N \\
N \\
N \\
N \\
N \\
-7 \\
N \\
N \\
N \\
N \\
N \\
N \\
N \\
N \\
N \\
N\end{array}$ & $\begin{array}{c}N \\
N \\
N \\
N \\
N \\
N \\
N \\
-14 \\
N \\
N \\
N \\
N \\
N \\
N \\
N \\
N \\
N \\
N\end{array}$ & $\begin{array}{l}<10 \\
<10 \\
<10 \\
<10 \\
<10 \\
<10 \\
<10 \\
<10 \\
<10 \\
<10 \\
<10 \\
<10 \\
<10 \\
<10 \\
<10 \\
<10 \\
<10 \\
<10\end{array}$ \\
\hline \multicolumn{11}{|l|}{$Q A / Q C$} \\
\hline $\begin{array}{l}\text { Equipment Blank } \\
\text { Trip Blank } \\
\text { Trip Blank }\end{array}$ & $\begin{array}{l}\text { MLY Y }-732 \\
\text { MLY }-676 \\
\text { MLY Y } 687\end{array}$ & $\begin{array}{l}03 / 17 / 1992 \\
03 / 16 / 1992 \\
03 / 18 / 1992\end{array}$ & $\begin{array}{l}N \\
N \\
N\end{array}$ & $\begin{array}{l}<10 \\
N \\
N\end{array}$ & $\begin{array}{l}N \\
N \\
N\end{array}$ & $\begin{array}{l}N \\
N \\
N\end{array}$ & $\begin{array}{l}N \\
N \\
N\end{array}$ & $\begin{array}{l}N \\
N \\
N\end{array}$ & $\begin{array}{l}N \\
N \\
N\end{array}$ & $\begin{array}{l}<10 \\
-2.3 \\
-3.1\end{array}$ \\
\hline
\end{tabular}

aCAS Number 112-95-8 Eicosane

CAS Number 117-81-7 Bis(2-ethylhexyl)phthalate

CAS Number 17302-32-8 Nonane, 3,7-dimethyl-

CAS Number 544-76-3 Hexadecane

CAS Number 62016-18-6 Octane, 5-ethyl-2-methyl-

CAS Number 629-99-2 Pentacosane

CAS Number 630-02-4 Octacosane

CAS Number 74-83-9 Bromomethane

$b_{A}$ "<" indicates that the maximum concentration was below reporting limits (number shown is reporting limit). A " " indicates an approximate value (the value was outside the 1 imits for which the instrument was calibrated)

cSemivolatile compound.

dentatively identified compound.

eTCL constituent.

fVolatile compound

gNot observed. 
Table A-23 (continued). Organic Constituents Observed in Samples Collected from Ground Water at the GJP0, March 16 through March 18, 1992a,b

\begin{tabular}{|c|c|c|c|c|c|c|c|c|c|c|}
\hline $\begin{array}{l}\text { Sample } \\
\text { Location }\end{array}$ & $\begin{array}{l}\text { Ticket } \\
\text { Number }\end{array}$ & $\begin{array}{l}\text { Sample } \\
\text { Date }\end{array}$ & $\begin{array}{c}74-87-3 e, f \\
(\mu g / L)\end{array}$ & $\begin{array}{c}75-09-2^{e, f} \\
(\mu g / L)\end{array}$ & $\begin{array}{c}84-74-2 c, e \\
(\mu g / L)\end{array}$ & $\begin{array}{l}\text { Unk-10.34c,d } \\
(\mu g / L)\end{array}$ & $\begin{array}{l}\operatorname{lnm}_{(\mu g / L)}-10.37 c, d \\
\end{array}$ & $\begin{array}{l}\text { Unx-10.39c,d } \\
(\mu g / L)\end{array}$ & $\begin{array}{l}(\mu / L) \\
(\mu / L), 87 c, d v\end{array}$ & $\begin{array}{l}(\mu g / L) \\
\text { (n)-19.8gc,d }\end{array}$ \\
\hline \multicolumn{11}{|l|}{ Ground Mater } \\
\hline $\begin{array}{l}1-9 S A \\
10-19 N \\
11-1 S \\
13-16 N A \\
13-16 N A \text { (Dup) } \\
14-13 N A \\
14-6 N A \\
3-3 N A \\
5-12 N A \\
\text { GJ84-04 } \\
\text { GJ84-05 } \\
\text { GJ84-06 } \\
\text { GJ84-09 } \\
\text { GJ84-10 } \\
\text { P-2A } \\
\text { P-3A } \\
\text { P-4A } \\
\text { P-6 }\end{array}$ & $\begin{array}{l}M L Y-734 \\
M L Y-684 \\
M L Y-682 \\
M L Y-728 \\
M L Y-729 \\
M L Y-730 \\
M L Y-683 \\
M L Y-736 \\
M L Y-737 \\
M L Y-731 \\
M L Y-733 \\
M L Y-690 \\
M L Y-735 \\
M L Y-727 \\
M L Y-688 \\
M L Y-685 \\
M L Y-689 \\
M L Y-686\end{array}$ & $\begin{array}{l}03 / 18 / 1992 \\
03 / 17 / 1992 \\
03 / 17 / 1992 \\
03 / 17 / 1992 \\
03 / 17 / 1992 \\
03 / 17 / 1992 \\
03 / 17 / 1992 \\
03 / 18 / 1992 \\
03 / 18 / 1992 \\
03 / 17 / 1992 \\
03 / 17 / 1992 \\
03 / 18 / 1992 \\
03 / 18 / 1992 \\
03 / 16 / 1992 \\
03 / 18 / 1992 \\
03 / 17 / 1992 \\
03 / 18 / 1992 \\
03 / 18 / 1992\end{array}$ & $\begin{array}{l}<10 \\
<10 \\
10 \\
<10 \\
<10 \\
\sim 1.7 \\
\sim 5.5 \\
<10 \\
\sim 3.3 \\
<10 \\
<10 \\
\sim 1.0 \\
<10 \\
<10 \\
-3.1 \\
<10 \\
\sim 1.7 \\
<10\end{array}$ & $\begin{array}{l}<5 \\
-1.9 \\
<5 \\
<5 \\
-1.2 \\
-1.2 \\
<5 \\
<5 \\
<5 \\
<5 \\
\sim 1.0 \\
<5 \\
<5 \\
<5 \\
<5 \\
-0.92 \\
<5 \\
<5\end{array}$ & $\begin{array}{r}<10 \\
<10 \\
<10 \\
<10 \\
<10 \\
<10 \\
\sim 5 \\
<10 \\
<10 \\
<10 \\
<10 \\
<10 \\
<10 \\
<10 \\
<10 \\
<10 \\
<10 \\
<10\end{array}$ & $\begin{array}{l}N g \\
N \\
N \\
N \\
N \\
N \\
N \\
N \\
-15 \\
N \\
N \\
N \\
N \\
N \\
N \\
N \\
N \\
N\end{array}$ & $\begin{array}{l}N \\
N \\
N \\
N \\
N \\
\sim 3 \\
N \\
N \\
N \\
N \\
N \\
N \\
N \\
-6 \\
N \\
N \\
N \\
N\end{array}$ & $\begin{array}{l}N \\
N \\
\sim 2 \\
N \\
N \\
N \\
N \\
N \\
N \\
N \\
N \\
N \\
N \\
N \\
N \\
N \\
N \\
N\end{array}$ & $\begin{array}{l}N \\
-3 \\
N \\
N \\
N \\
N \\
N \\
N \\
N \\
N \\
N \\
N \\
N \\
N \\
N \\
N \\
N \\
N\end{array}$ & $\begin{array}{l}2 \\
N \\
N \\
N \\
\sim 2 \\
N \\
N \\
N \\
N \\
N \\
N \\
N \\
N \\
N \\
N \\
N \\
N \\
N\end{array}$ \\
\hline \multicolumn{11}{|l|}{$Q A / Q C$} \\
\hline $\begin{array}{l}\text { Equipment Blank } \\
\text { Trip Blank } \\
\text { Trip Blank }\end{array}$ & $\begin{array}{l}\text { MLY }-732 \\
\text { MLY }-676 \\
\text { MLY }-687\end{array}$ & $\begin{array}{l}03 / 17 / 1992 \\
03 / 16 / 1992 \\
03 / 18 / 1992\end{array}$ & $\begin{array}{r}<10 \\
61 \\
30\end{array}$ & $\begin{array}{l}<5 \\
<5 \\
<5\end{array}$ & $\begin{array}{r}<10 \\
N \\
N\end{array}$ & $\begin{array}{l}N \\
N \\
N\end{array}$ & $\begin{array}{l}N \\
N \\
N\end{array}$ & $\begin{array}{l}N \\
N \\
N\end{array}$ & $\begin{array}{l}N \\
N \\
N\end{array}$ & $\begin{array}{l}\mathbf{N} \\
\mathbf{N} \\
\mathbf{N}\end{array}$ \\
\hline $\begin{array}{c}\text { aCAS Number } \\
\text { CAS Number } \\
\text { CAS Number } \\
\text { CAS Number } \\
\text { CAS Number } \\
\text { CAS Number } \\
\text { CAS Number } \\
\text { CAS Number } \\
\text { bA "<" indica } \\
\text { value (the value } \\
\text { cSemivolatile } \\
\text { dTentatively } \\
\text { eTCL constitu } \\
\text { f Volatile com } \\
\text { gNot observed }\end{array}$ & $\begin{array}{l}84-74-2 \\
\text { UNK-10.34 } \\
\text { UNK-10.37 } \\
\text { UNK-10.39 } \\
\text { UNK-19.87 } \\
\text { UNK-19.89 } \\
74-87-3 \\
75-09-2 \\
\text { tes that th } \\
\text { as outside } \\
\text { compound. } \\
\text { dentified } \\
\text { ent. } \\
\text { pound. }\end{array}$ & $\begin{array}{l}\text { Di-n-butylpht } \\
\text { Unknown } \\
\text { Unknown } \\
\text { Unknown } \\
\text { Unknown } \\
\text { Unknown } \\
\text { Chloromethane } \\
\text { Methylene chl } \\
\text { ne maximum cono } \\
\text { the limits for } \\
\text { compound. }\end{array}$ & $\begin{array}{l}\text { thalate } \\
\text { loride } \\
\text { centration wo } \\
\text { which the }\end{array}$ & $\begin{array}{l}\text { as below repo } \\
\text { instrument wa }\end{array}$ & $\begin{array}{l}\text { ting limits } \\
\text { calibrated }\end{array}$ & (number shown & s reporting & nit). A " & ndicates an & roximate \\
\hline
\end{tabular}


Table A-23 (continued). Organic Constituents Observed in Samples Collected from Ground Water at the GJPO, March 16 through March 18, 1992a,b

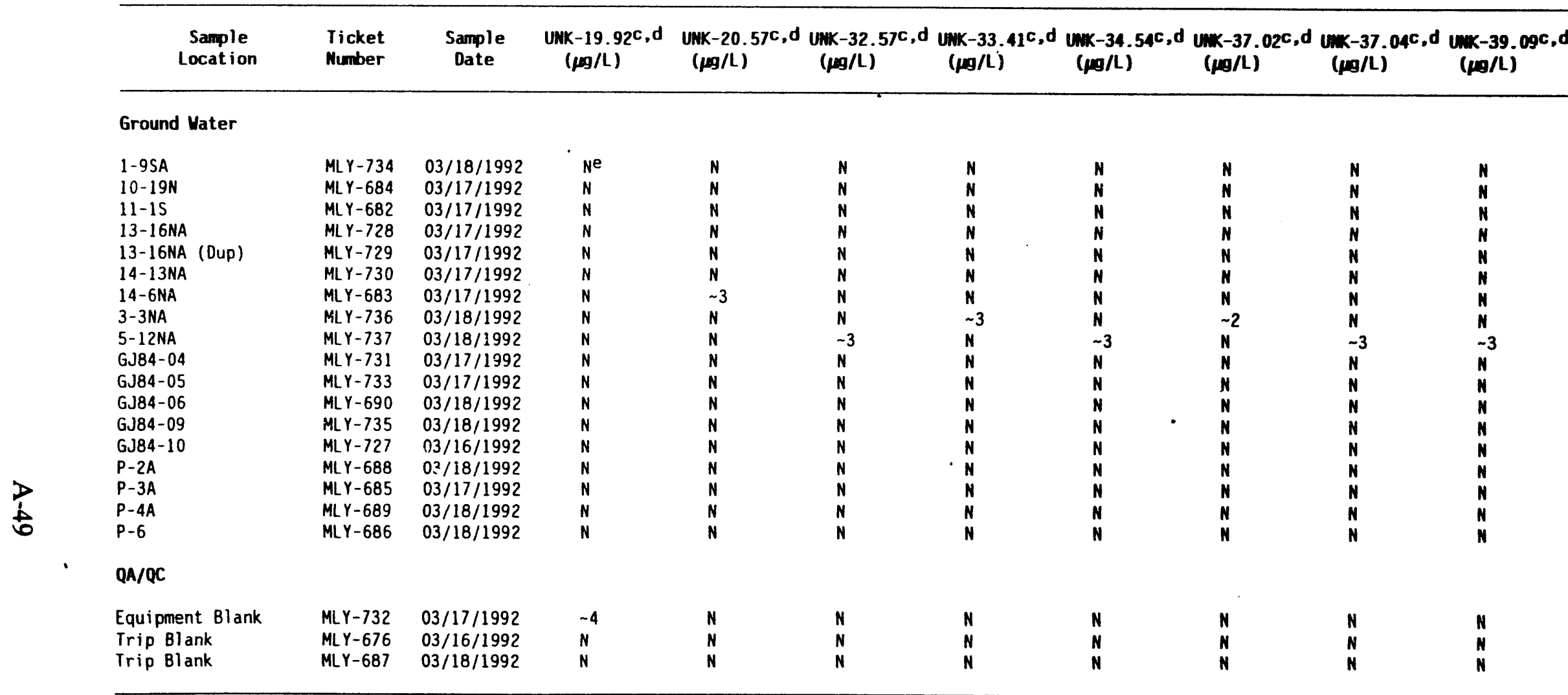

aCAS Number UNK-19.92 Unknown

CAS Number UNK-20.57 Unknown

CAS Number UNK-32.57 Unknown hydrocarbon

CAS Number UNK-33.41 Unknown

CAS Nuriber UNK-34.54 Unknown hydrocarbon

CAS Number UNK-37.02 Unknown hydrocarbon

CAS Number UNK-37.04 Unknown hydrocarbon

CAS Number UNK-39.09 Unknown hydrocarbon

$b_{A}$ " " indicates an approximate value (the value was outside the limits for which the instrument was calibrated).

cSemivolatile compound.

dTentatively identified compound.

e Not observed. 
Table A-23 (continued). Organic Constituents Observed in Samples Collected from Ground Water at the GJPO, March 16 through March 18, 1992a,b

\begin{tabular}{|c|c|c|c|}
\hline $\begin{array}{l}\text { Sample } \\
\text { Location }\end{array}$ & $\begin{array}{l}\text { Ticket } \\
\text { Nuber }\end{array}$ & $\begin{array}{c}\text { Sapple } \\
\text { Date }\end{array}$ & $\underset{(\mu g / L)}{\ln x-9.37 c, d}$ \\
\hline Ground Hater & & & \\
\hline $\begin{array}{l}1-9 S A \\
10-19 N \\
11-1 S \\
13-16 N A \\
13-16 N A \text { (Dup) } \\
14-13 N A \\
14-6 N A \\
3-3 N A \\
5-12 N A \\
\text { GJ84-04 } \\
\text { GJ84-05 }- \\
\text { GJ84-06 } \\
\text { GJ84-09 } \\
\text { GJ84-10 } \\
P-2 A \\
P-3 A \\
P-4 A \\
P-6\end{array}$ & 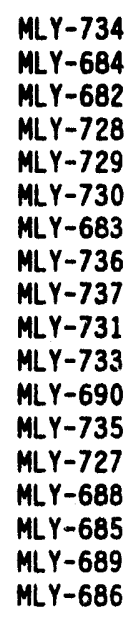 & $\begin{array}{l}03 / 18 / 1992 \\
03 / 17 / 1992 \\
03 / 17 / 1992 \\
03 / 17 / 1992 \\
03 / 17 / 1992 \\
03 / 17 / 1992 \\
03 / 17 / 1992 \\
03 / 18 / 1992 \\
03 / 18 / 1992 \\
03 / 17 / 1992 \\
03 / 17 / 1992 \\
03 / 18 / 1992 \\
03 / 18 / 1992 \\
03 / 16 / 1992 \\
03 / 18 / 1992 \\
03 / 17 / 1992 \\
03 / 18 / 1992 \\
03 / 18 / 1992\end{array}$ & $\begin{array}{l}N e \\
N \\
-3 \\
N \\
N \\
N \\
N \\
N \\
N \\
N \\
N \\
N \\
N \\
N \\
N \\
N \\
-3 \\
N\end{array}$ \\
\hline \multicolumn{4}{|l|}{$Q A / Q C$} \\
\hline $\begin{array}{l}\text { Equipment Blank } \\
\text { Trip Blank } \\
\text { Trip Blank }\end{array}$ & $\begin{array}{l}\text { MLY }-732 \\
\text { MLY-676 } \\
\text { MLY-687 }\end{array}$ & $\begin{array}{l}03 / 17 / 1992 \\
03 / 16 / 1992 \\
03 / 18 / 1992\end{array}$ & $\begin{array}{l}N \\
N \\
N\end{array}$ \\
\hline
\end{tabular}

aCAS Number UNK-9.37 Unknown

$b_{A}$ " " indicates an approximate value (the value

was outside the limits for which the instrument was calibrated).

cSemivolatile compound.

dTentatively identified compound.

e Not observed. 
Table A-24. Organic Constituents Observed in Samples Collected from Ground Water at the GJP0, September 8 through September 14, 1992a,b

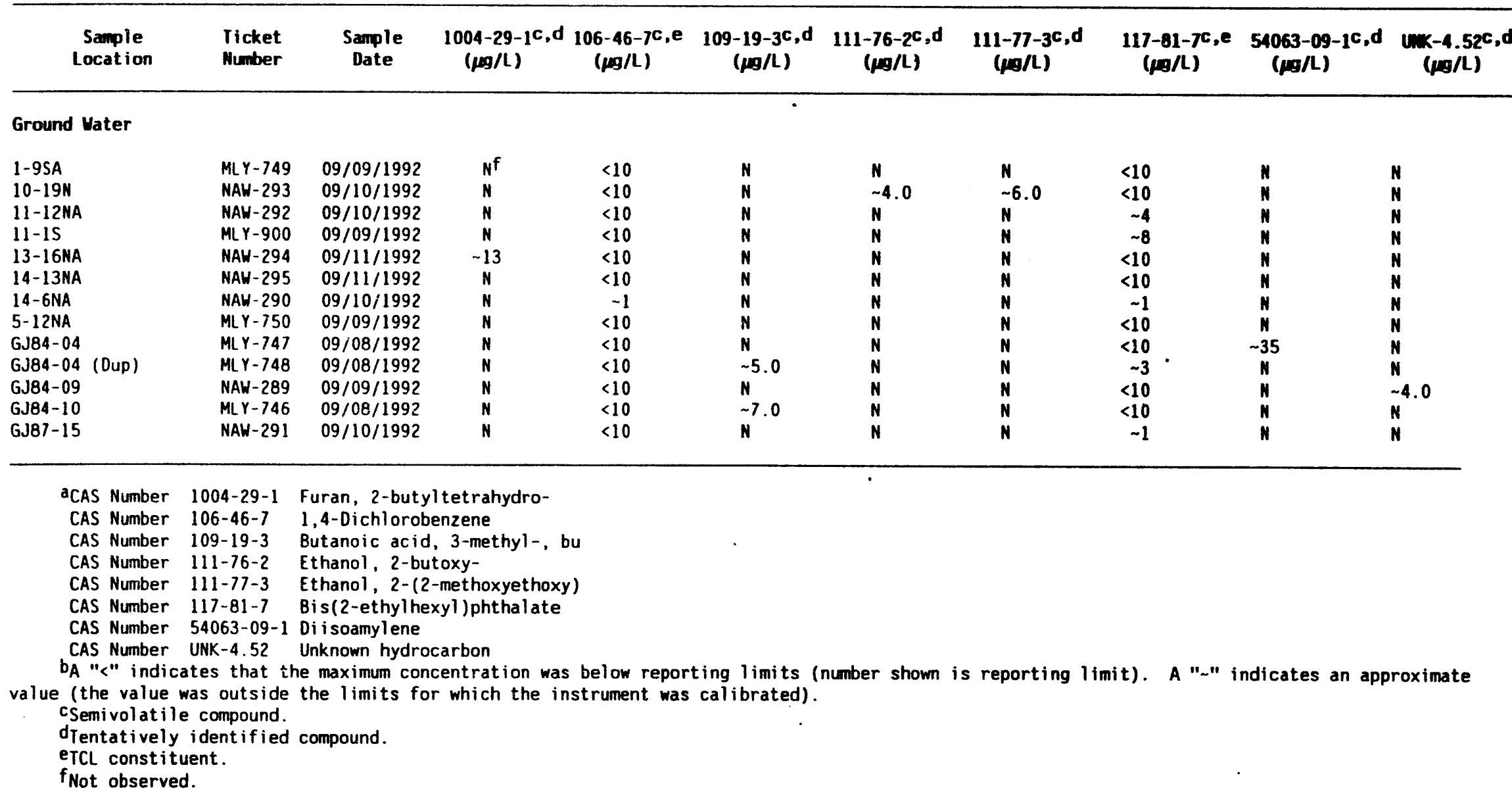


Table A-24 (continued). Oraanic Constituents Ohserved in Samples Collected from Ground Water at the GJPO, September 8 through September 14, 1992a,b

\begin{tabular}{|c|c|c|c|c|c|c|c|c|c|}
\hline $\begin{array}{l}\text { Sample } \\
\text { Location }\end{array}$ & $\begin{array}{l}\text { Ilcket } \\
\text { Number }\end{array}$ & $\begin{array}{l}\text { Sample } \\
\text { Date }\end{array}$ & $\begin{array}{l}\left(\mu \mathrm{mk}-1.53^{c} \cdot d\right) \\
(\mu \mathrm{l})\end{array}$ & $\begin{array}{l}\text { Unk }-5.12^{c}, d \\
(\mu g / L)\end{array}$ & $\begin{array}{l}\text { Uax- } 5.13^{c}, d \\
(\mu g / L)\end{array}$ & $\begin{array}{l}\text { UnK- }-5.15^{c, d} \\
(\mu g / L)\end{array}$ & $\begin{array}{l}\text { UNK- } 5.35 c, d \\
(\mu g / L)\end{array}$ & 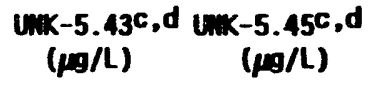 & $\begin{array}{l}\operatorname{lom}-5.47 c, d \\
(\mu g / L)\end{array}$ \\
\hline
\end{tabular}

\section{Ground Vater}

1 - 9SA
$10-19 \mathrm{~N}$
$11-12 \mathrm{NA}$
$11-15$
$13-16 \mathrm{NA}$
$14-13 \mathrm{NA}$
$14-6 \mathrm{NA}$
$5-12 \mathrm{NA}$
GJ84-04
GJ84-04 (Dup)
GJ84-09
GJ84-10
GJ87-15

$\begin{array}{ll}\text { MLY- } 149 & 09 / 09 / 1992 \\ \text { NAW.293 } & 09 / 10 / 1992 \\ \text { NAW-292 } & 09 / 10 / 1992 \\ \text { MLY-900 } & 09 / 09 / 1992 \\ \text { NAW-294 } & 09 / 11 / 1992 \\ \text { NAH-295 } & 09 / 11 / 1992 \\ \text { NAW-290 } & 09 / 10 / 1992 \\ \text { MLY-750 } & 09 / 09 / 1992 \\ \text { MIY-747 } & 09 / 08 / 1992 \\ \text { MLY-748 } & 09 / 08 / 1992 \\ \text { NAW-289 } & 09 / 09 / 1992 \\ \text { MLY-746 } & 09 / 08 / 1992 \\ \text { NAW-291 } & 09 / 10 / 1992\end{array}$

$\begin{array}{ll}N e & -11 \\ N & N \\ N & N \\ N & N \\ N & N \\ N & N \\ -4.0 & N \\ N & -13 \\ N & N \\ N & -8.0 \\ N & N \\ N & N \\ N & N\end{array}$

•

aCAS Number UNK-4.53 Unknown hydrocarbon

CAS Number UNK-5.12 Unknown hydrocarbon

CAS Number UNK-5.13 Unknown hydrocarbon

CAS Number UNK-5.15 Unknown hydrocarbon

CAS Number UNK-5.35 Unknown hydrocarbon

CAS Number UNK-5.43 Unknown hydrocarbon

CAS Number UNK-5.45 Unknown hydrocarbon

CAS Number UNK-5.47 Unknown hydrocarbon
$b_{A}$ " " indicates an approximate value (the value was outside the 1 imits for which the instrument was calibrated).

CSemivolatile compound.

dTentatively identified compound.

eNot observed. 
Table A-24 (continued). Organic Constituents Observed in Samples Collected from Ground Water at the GJP0, September 8 through September 14, 1992a,b

\begin{tabular}{|c|c|c|c|c|c|c|c|c|c|c|}
\hline $\begin{array}{l}\text { Sample } \\
\text { Location }\end{array}$ & $\begin{array}{l}\text { Ticket } \\
\text { Humber }\end{array}$ & $\begin{array}{l}\text { Sample } \\
\text { Date }\end{array}$ & $\begin{array}{c}\text { UNK-5.48C,d } \\
(\mu \mathrm{g} / \mathrm{L})\end{array}$ & $\begin{array}{c}\text { UnK-5.63c,d } \\
(\mu \mathrm{g} / \mathrm{L})\end{array}$ & $\begin{array}{l}\text { Uax }-5.65 C, d \\
(\mu g / L)\end{array}$ & $\begin{array}{c}\operatorname{lark}-5.67 c, d \\
(\mu g / L)\end{array}$ & $\begin{array}{c}u n k-5.73 c, d \\
(p g / L)\end{array}$ & $\begin{array}{c}\text { UnK-5.75c,d } \\
(\mu g / L)\end{array}$ & $\begin{array}{l}\text { Uix }-5.90 c, d \\
(\mu g / L)\end{array}$ & $\begin{array}{c}\text { (n) } 1 \text {-5.97c, } \\
(\mu g / L)\end{array}$ \\
\hline Ground Hater & & & ${ }^{\circ}$ & & & & & & & \\
\hline $\begin{array}{l}1-9 S A \\
10-19 N \\
11-12 N A \\
11-15 \\
13-16 N A \\
14-13 N A \\
14-6 N A \\
5-12 N A \\
\text { GJ84-04 } \\
\text { GJ84-04 (Dup) } \\
\text { GJ84-09 } \\
\text { GJ84-10 } \\
\text { GJ87-15 }\end{array}$ & $\begin{array}{l}\text { MLY } Y-749 \\
\text { NAW-293 } \\
\text { NAW-292 } \\
\text { MLY-900 } \\
\text { NAW-294 } \\
\text { NAW-295 } \\
\text { NAW-290 } \\
\text { MLY-750 } \\
\text { MLY-747 } \\
\text { MLY-748 } \\
\text { NAW-289 } \\
\text { MLY-746 } \\
\text { NAW-291 }\end{array}$ & $\begin{array}{l}09 / 09 / 1992 \\
09 / 10 / 1992 \\
09 / 10 / 1992 \\
09 / 09 / 1992 \\
09 / 11 / 1992 \\
09 / 11 / 1992 \\
09 / 10 / 1992 \\
09 / 09 / 1992 \\
09 / 08 / 1992 \\
09 / 08 / 1992 \\
09 / 09 / 1992 \\
09 / 08 / 1992 \\
09 / 10 / 1992\end{array}$ & $\begin{array}{c}N e \\
N \\
N \\
N \\
N \\
N \\
\sim 20 \\
N \\
N \\
N \\
N \\
N \\
\sim 16\end{array}$ & $\begin{array}{l}-3.0 \\
-3.0 \\
N \\
N \\
N \\
N \\
N \\
N \\
N \\
-2.0 \\
N \\
N \\
N\end{array}$ & $\begin{array}{l}N \\
N \\
N \\
N \\
N \\
N \\
N \\
\sim 4.0 \\
\sim 3.0 \\
N \\
N \\
N \\
N\end{array}$ & $\begin{array}{l}N \\
N \\
N \\
N \\
N \\
N \\
N \\
N \\
N \\
N \\
N \\
\sim 3.0 \\
N\end{array}$ & $\begin{array}{l}N \\
N \\
-6.0 \\
N \\
N \\
N \\
N \\
N \\
N \\
N \\
-3.0 \\
N \\
N\end{array}$ & $\begin{array}{l}N \\
N \\
N \\
N \\
N \\
N \\
-3.0 \\
N \\
N \\
N \\
N \\
N \\
\sim 2.0\end{array}$. & $\begin{array}{l}N \\
N \\
N \\
N \\
N \\
\sim 5.0 \\
N \\
N \\
N \\
N \\
N \\
N \\
N\end{array}$ & $\begin{array}{l}N \\
N \\
-3.0 \\
N \\
N \\
N \\
N \\
N \\
N \\
N \\
N \\
N \\
N\end{array}$ \\
\hline
\end{tabular}

aCAS Number UNK-5.48 Unknown hydrocarbon

CAS Number UNK-5.63 Unknown hydrocarbon

CAS Number UNK-5.65 Unknown hydrocarbon

CAS Number UNK -5.67 Unknown hydrocarbon

CAS Number UNK-5.73 Unknown hydrocarbon

CAS Number UNK-5.75 Unknown hydrocarbon

CAS Number UNK-5.90 Unknown hydrocarbon

CAS Number UNK-5.97 Unknown chlorinated hydrocarbon

$b_{A}$ " " indicates an approximate value (the value was outside the limits for which the instrument was calibrated).

CSemivolatile compound.

dentatively identified compound.

eNot observed. 
Table A-24 (continued). Organic Constituents Observed in Samples Collected from Ground Water at the GJPO, September 8 through September 14, 1992a,b

\begin{tabular}{|c|c|c|c|c|c|c|c|c|c|c|}
\hline $\begin{array}{l}\text { Sample } \\
\text { Location }\end{array}$ & $\begin{array}{l}\text { Ticket } \\
\text { Number }\end{array}$ & $\begin{array}{l}\text { Sample } \\
\text { Date }\end{array}$ & $\begin{array}{l}\text { UNK-6.02c,d } \\
(\mu g / L)\end{array}$ & $\begin{array}{l}\text { UNK-6.03C,d } \\
(\mu \mathrm{gg} / \mathrm{L})\end{array}$ & $\begin{array}{c}\text { UnK-6.05c,d } \\
(\mu g / L)\end{array}$ & $\begin{array}{c}\text { Uim-6.07c,d } \\
(\mu g / L)\end{array}$ & $\begin{array}{l}\lim -6.10^{c}, d \\
(\mu g / L)\end{array}$ & $\begin{array}{l}\text { Uix-6.20c,d } \\
(\mu g / L)\end{array}$ & $\begin{array}{l}\text { Uax-6.22c,d } \\
(\mu g / L)\end{array}$ & $\begin{array}{c}\lim -6.25 C, d \\
(\mu g / L)\end{array}$ \\
\hline
\end{tabular}

\section{Ground Water}

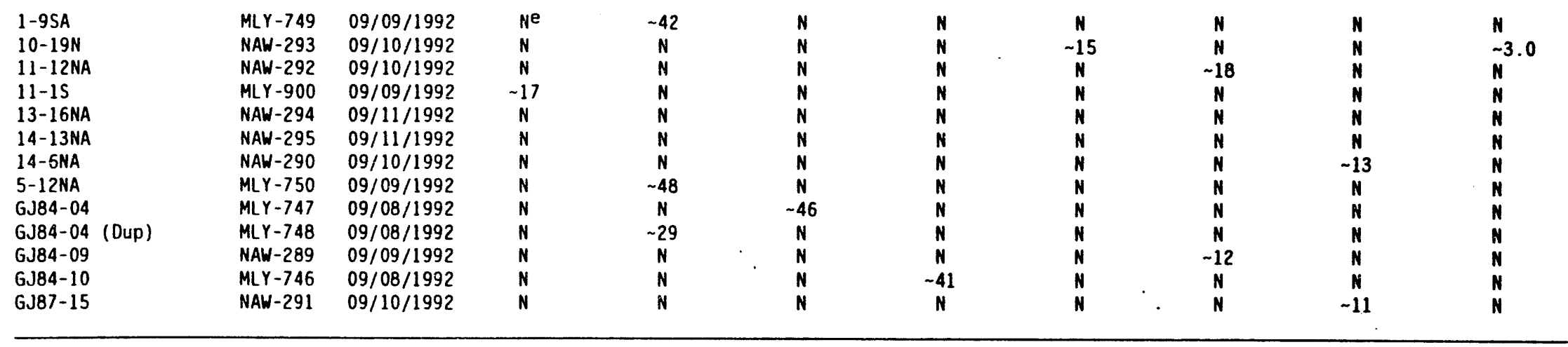

aCAS Number UNK-6.02 Unknown hydrocarbon

CAS Number UNK-6.03 Unknown hydrocarbon

CAS Number UNK-6.05 Unknown hydrocarbon

CAS Number UNK-6.07 Unknown

CAS Number UNK-6.10 Unknown hydrocarbon

CAS Number UNK-6.20 Unknowm hydrocarbon

CAS Number UNK-6.22 Unknown hydrocarbon

CAS Number UNK-6.25 Unknown hydrocarbon

$b_{A}$ " " indicates an approximate value (the value was outside the limits for which the instrument was calibrated).

"Semivolatile compound.

dTentatively identified compound.

eNot observed. 
Table A-24 (continued). Organic Constituents Observed in Samples Collected from Ground Water at the GJP0, September 8 thirough September 14, 1992a,b

\begin{tabular}{|c|c|c|c|c|c|c|c|c|c|c|}
\hline $\begin{array}{l}\text { Sample } \\
\text { Location }\end{array}$ & $\begin{array}{l}\text { Ticket } \\
\text { Nunber }\end{array}$ & $\begin{array}{l}\text { Sample } \\
\text { Date }\end{array}$ & $\begin{array}{l}\text { UnK-6.28c,d } \\
(\mu g / L)\end{array}$ & $\lim _{(m / L)}-6.30 c, d$ & $\lim _{(\mu g / L)}-6.32^{c, d}$ & $\begin{array}{l}\left.\lim _{(\mu / L)}-6\right)^{35}, d \\
\end{array}$ & $\begin{array}{l}\ln (\mu g / L) \\
(g / 37 c, d\end{array}$ & 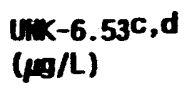 & $\lim _{(\mu g / L)}$ & $\lim _{(p g / L)}-6.58 a c, d$ \\
\hline \multicolumn{11}{|l|}{ Ground Mater } \\
\hline $1-95 A$ & MLY Y-749 & $09 / 09 / 1992$ & Ne & -7.0 & N & n & N & N & -3.0 & N \\
\hline $10-19 N$ & NAW-293 & $09 / 10 / 1992$ & N & $N$ & N & N & N & $\ddot{N}$ & N & N \\
\hline $11-12 \mathrm{NA}$ & NAW-292 & $09 / 10 / 1992$ & $\mathrm{H}$ & N & N & -3.0 & N & N & N & N \\
\hline $11-15$ & MLY $Y-900$ & $09 / 09 / 1992$ & -2.0 & N & N & $N$ & $\ddot{N}$ & N & $\ddot{N}$ & $\ddot{N}$ \\
\hline $13-16 N A$ & NAW-294 & $09 / 11 / 1992$ & N & N & N & N & N & N & $\ddot{N}$ & N \\
\hline $14-13 N A$ & NAW-295 & $09 / 11 / 1992$ & $\ddot{N}$ & N & $\ddot{N}$ & $\ddot{N}$ & N & N & N & N \\
\hline $14-6 \mathrm{NA}$ & NAW-290 & $09 / 10 / 1992$ & $N$ & $\mathbf{N}$ & N & $\mathbf{N}$ & -2.0 & N & n & N \\
\hline $5-12 N A$ & MLY $Y-750$ & 09/09/1992 & N & $\sim 8.0$ & $\ddot{N}$ & 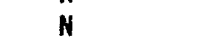 & $\mathrm{N}$ & $M$ & -4.0 & N \\
\hline GJ84-04 & MLY -747 & $09 / 08 / 1992$ & $\ddot{N}$ & $N$ & -6.0 & $\mathbf{N}$ & N & -4.0 & N & -2.0 \\
\hline GJ84-04 (Dup) & ML $Y-748$ & $09 / 08 / 1992$ & $\mathrm{~N}$ & $\ddot{N}$ & N & $\ddot{N}$ & N & N & $\ddot{N}$ & $n^{20}$ \\
\hline GJ84-09 & NAW-289 & $09 / 09 / 1992$ & N & N & N & -2.0 & N & N & N & N \\
\hline GJ84-10 & MLY $Y-746$ & $09 / 08 / 1992$ & N & $\mathrm{N}$ & N & N & N & $M$ & $M$ & N \\
\hline GJ87-15 & NAW-291 & $09 / 10 / 1992$ & N & $\mathbf{N}$ & N & $\mathbf{N}$ & • & $N$ & $N$ & $N$ \\
\hline
\end{tabular}

aCAS Number UNK-6.28 Unknown hydrocarbon

CAS Number UNK-6.30 Unknown hydrocarbon

CAS Number UNK-6.32 Unknown hydrocarbon

CAS Number UNK-6.35 Unknown hydrocarbon

CAS Number UNK-6.37 Unknown hydrocarbon

CAS Number UNK-6.53 Unkriuwr.

CAS Number UNK-6.58 Unknown hydrocarbon

CAS Number UNK-6.58a Unknown thiophene

$b_{A}$ " " indicates an approximate value (the value was outside the limits for which the instrument was calibrated)

cSemivolatile compound.

dTentatively identified compound.

eNot observed. 
Table A-24 (continued). Organic Constituents Observed in Samples Collected from Ground Water at the GJPO, September 8 through September 14, 1992a,b

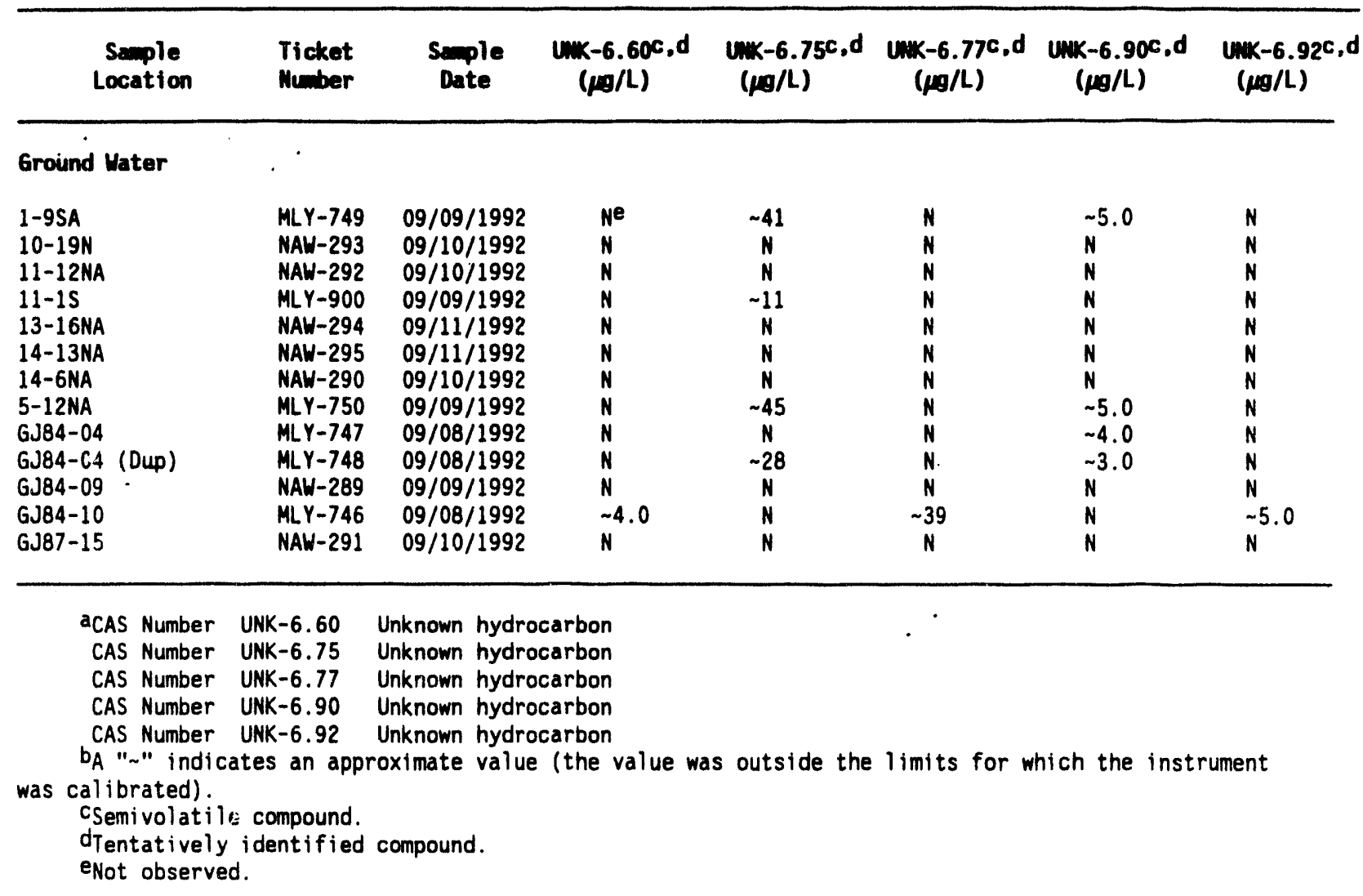


Appendix B

Time-Concentration Graphs 


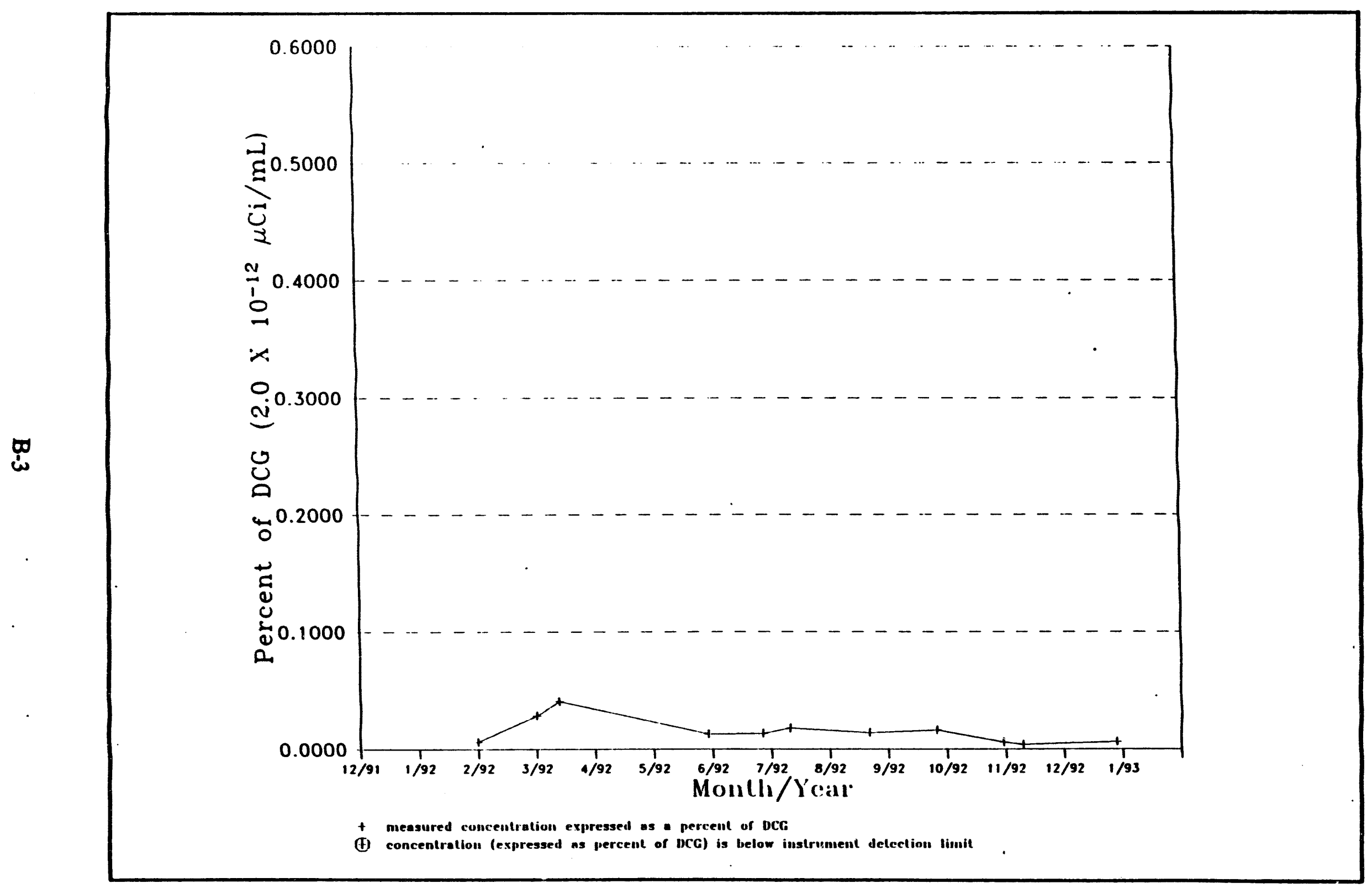

Figure B-1. Uranium Concentrations in Ambient Air as a Percentage of the DCG at Station AIR-G-2 from January to December 1992 


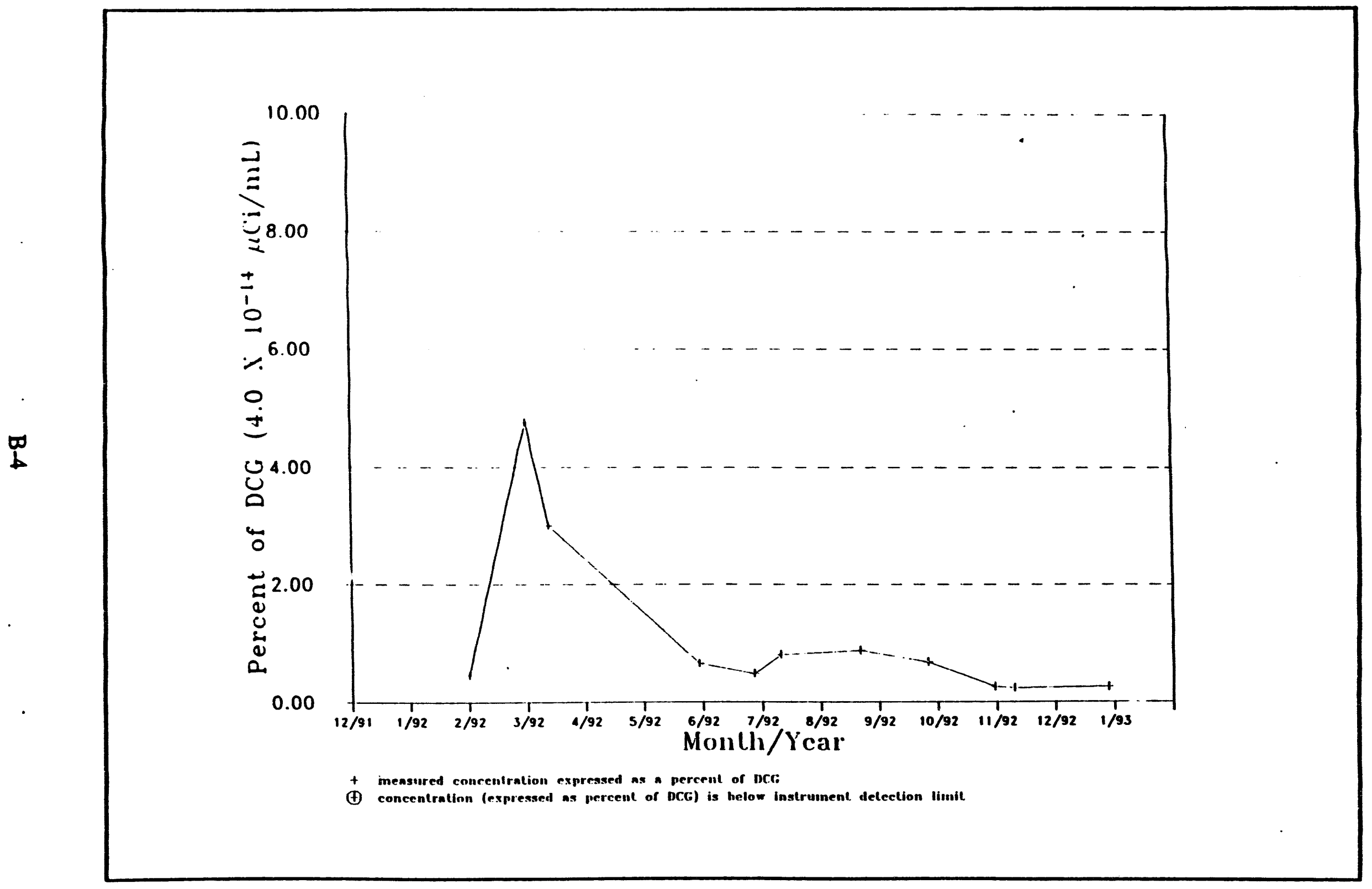

Figure B-2. Thorium-230 Concentrations in Ambient Air as a Percentage of the DCG at Station AIR-G-2 from January

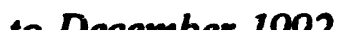




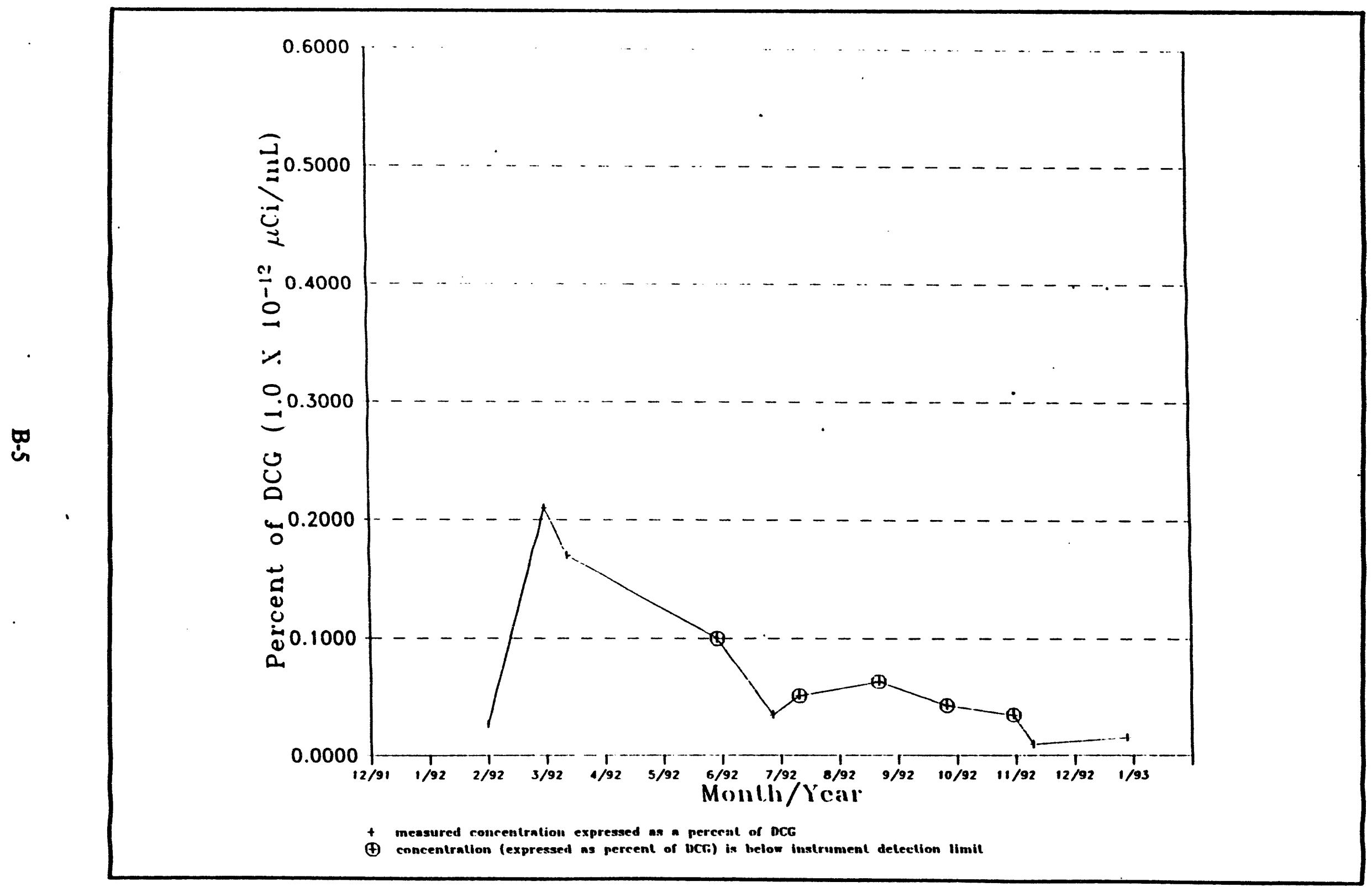

Figure B-3. Radium-226 Concentrations in Ambient Air as a Percentage of the DCG at Station Air-G-2 from January to December 1992 


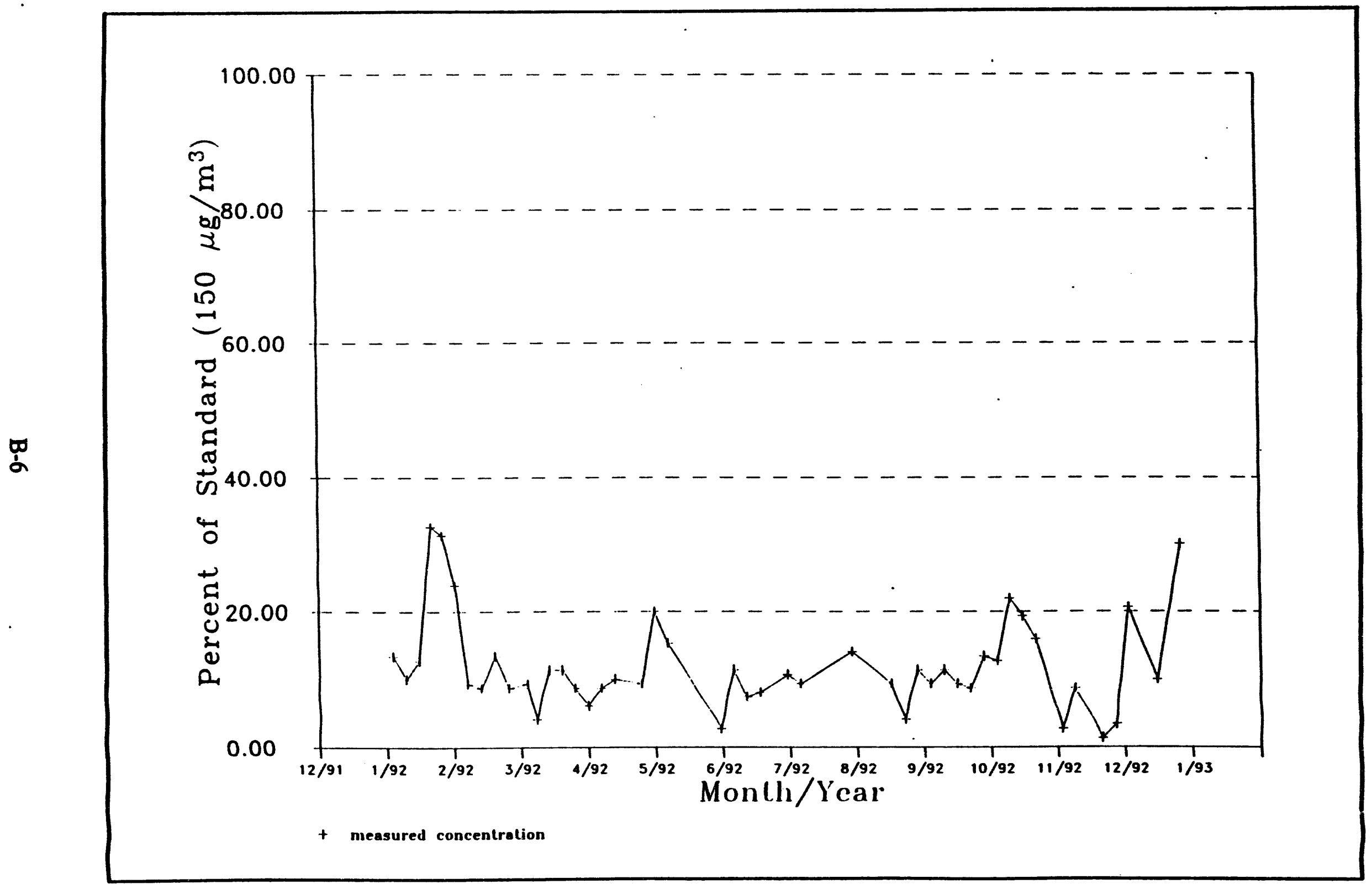

Figure B-4. $P M_{10}$ Concentrations in Ambient Air as a Percentage of the EPA/State Standard at Station AIR-G-2 


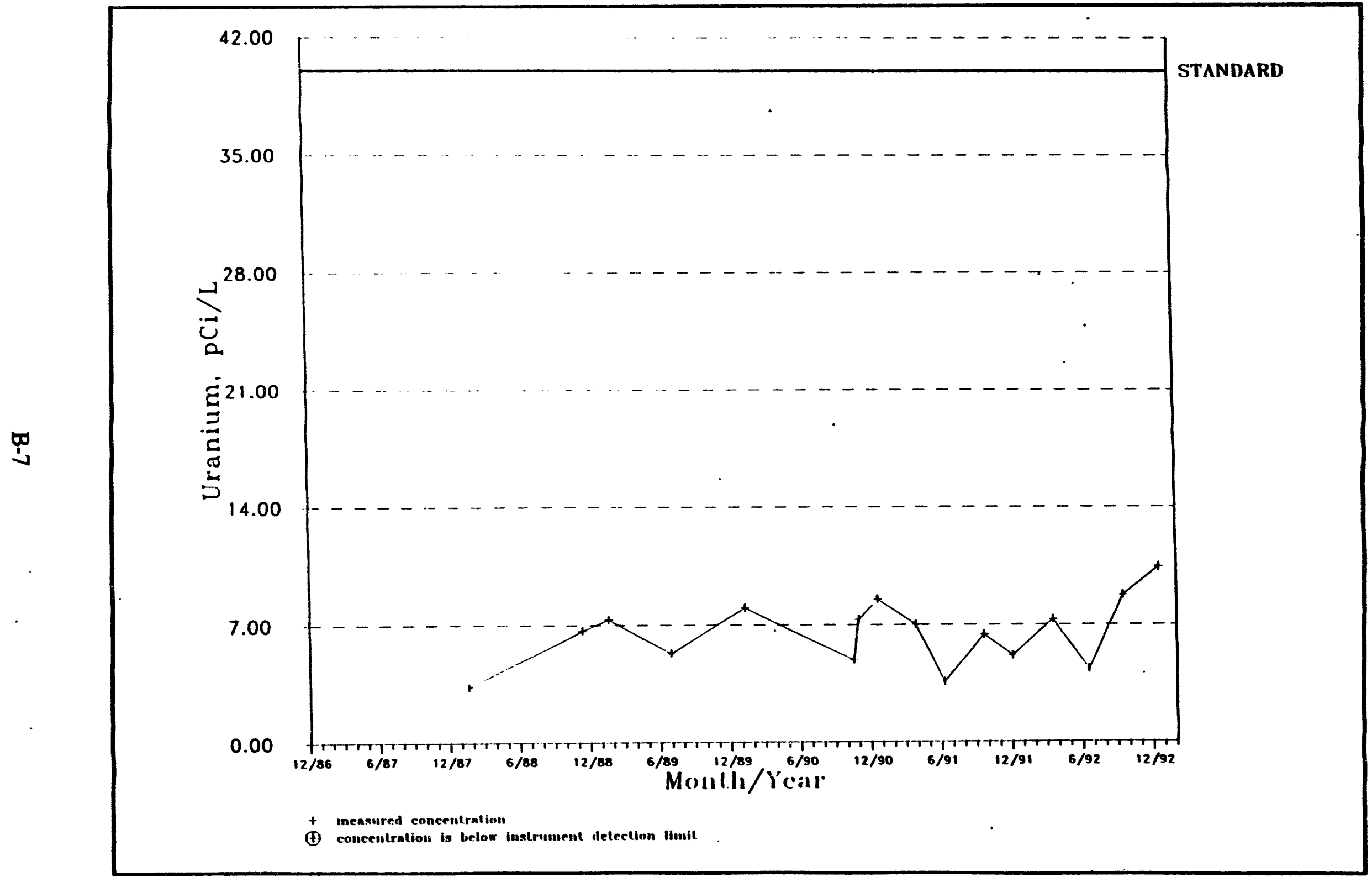

Figure B-5. Uranium Concentrations at the Upstream Gunnison River Sampling Location from January 1988 through December 1992 


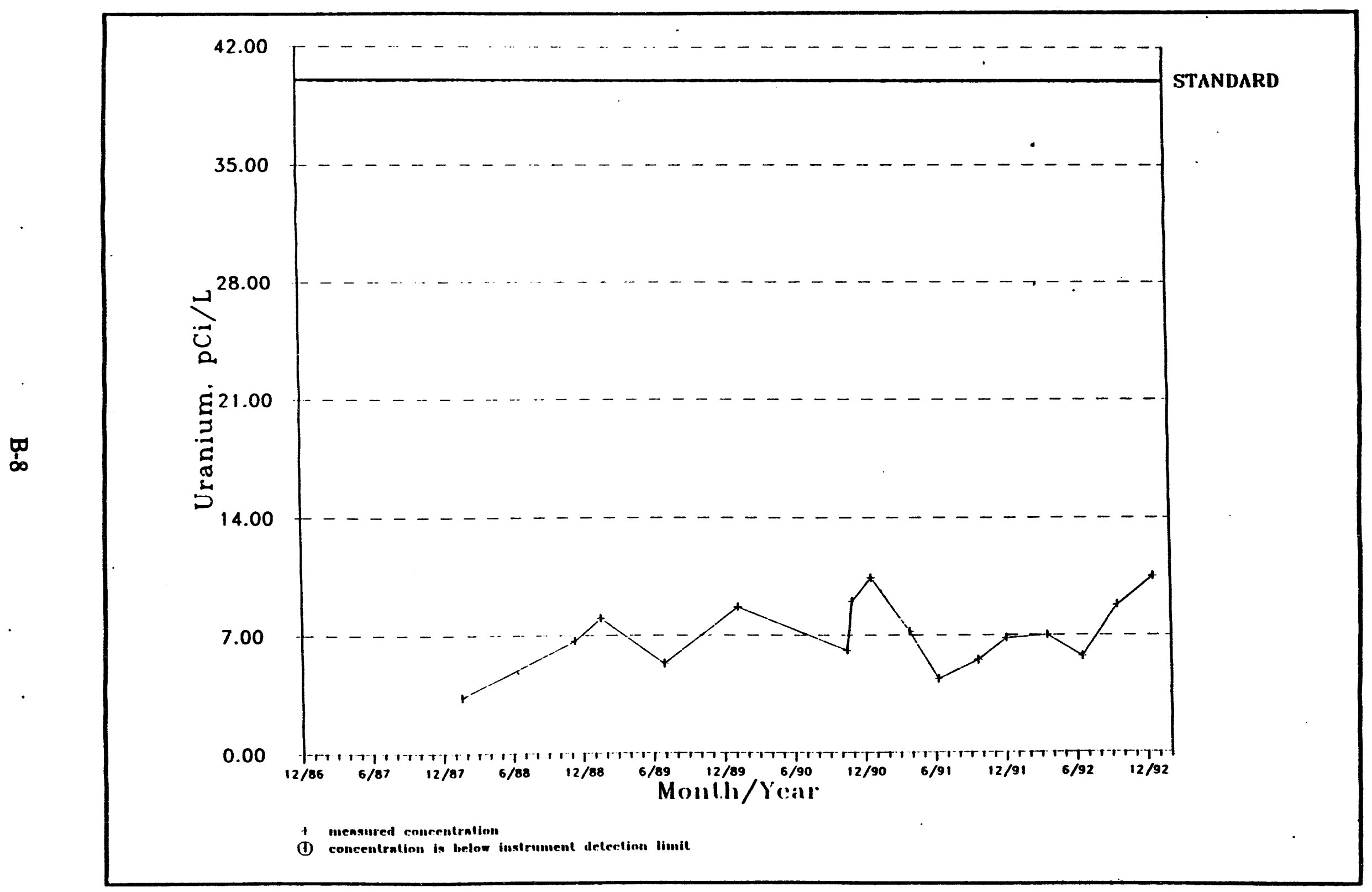

Figure B-6. Uranium Concentrations at the On-Site Gunnison River Sampling Location from January 1988 . In 


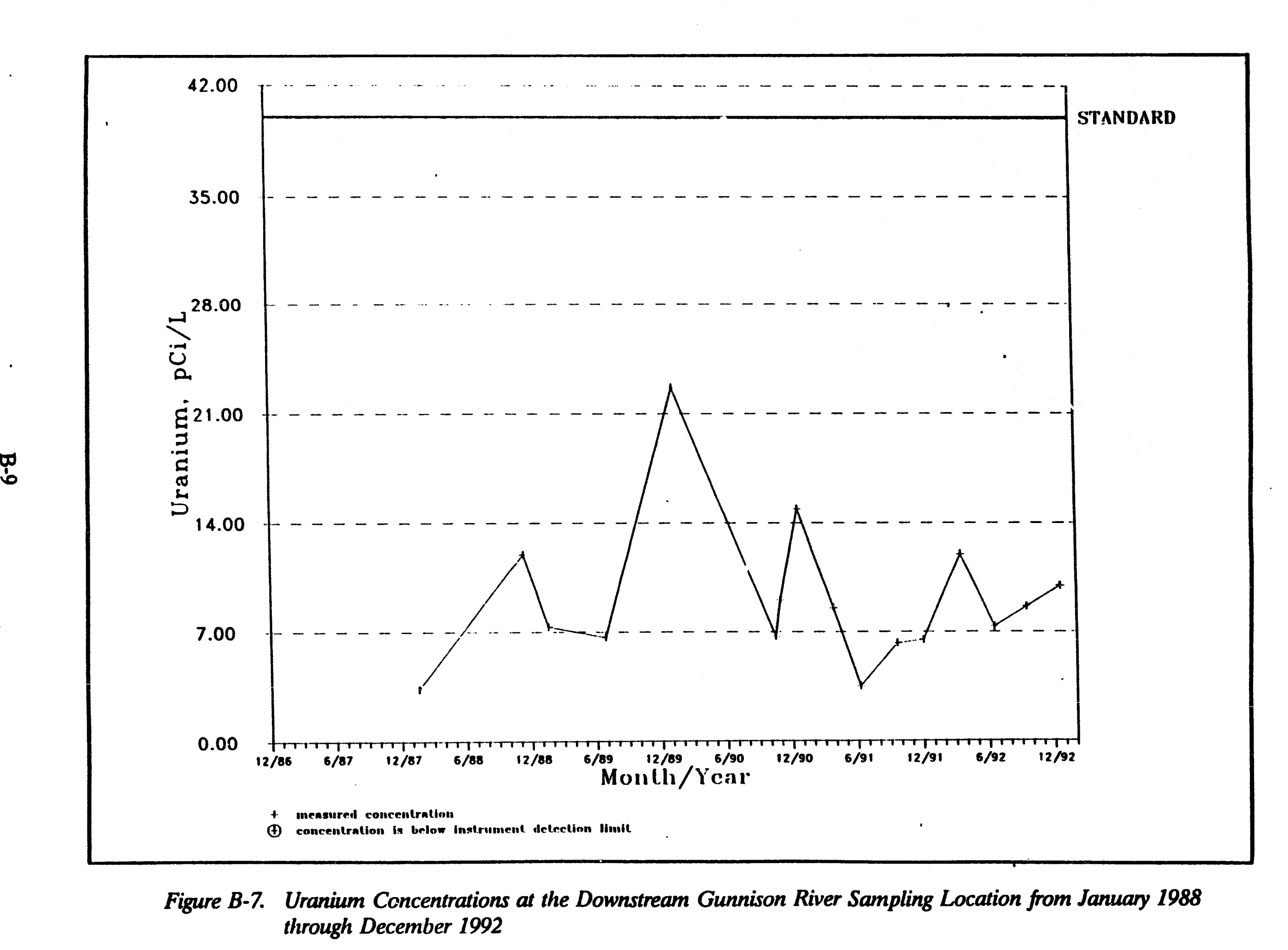




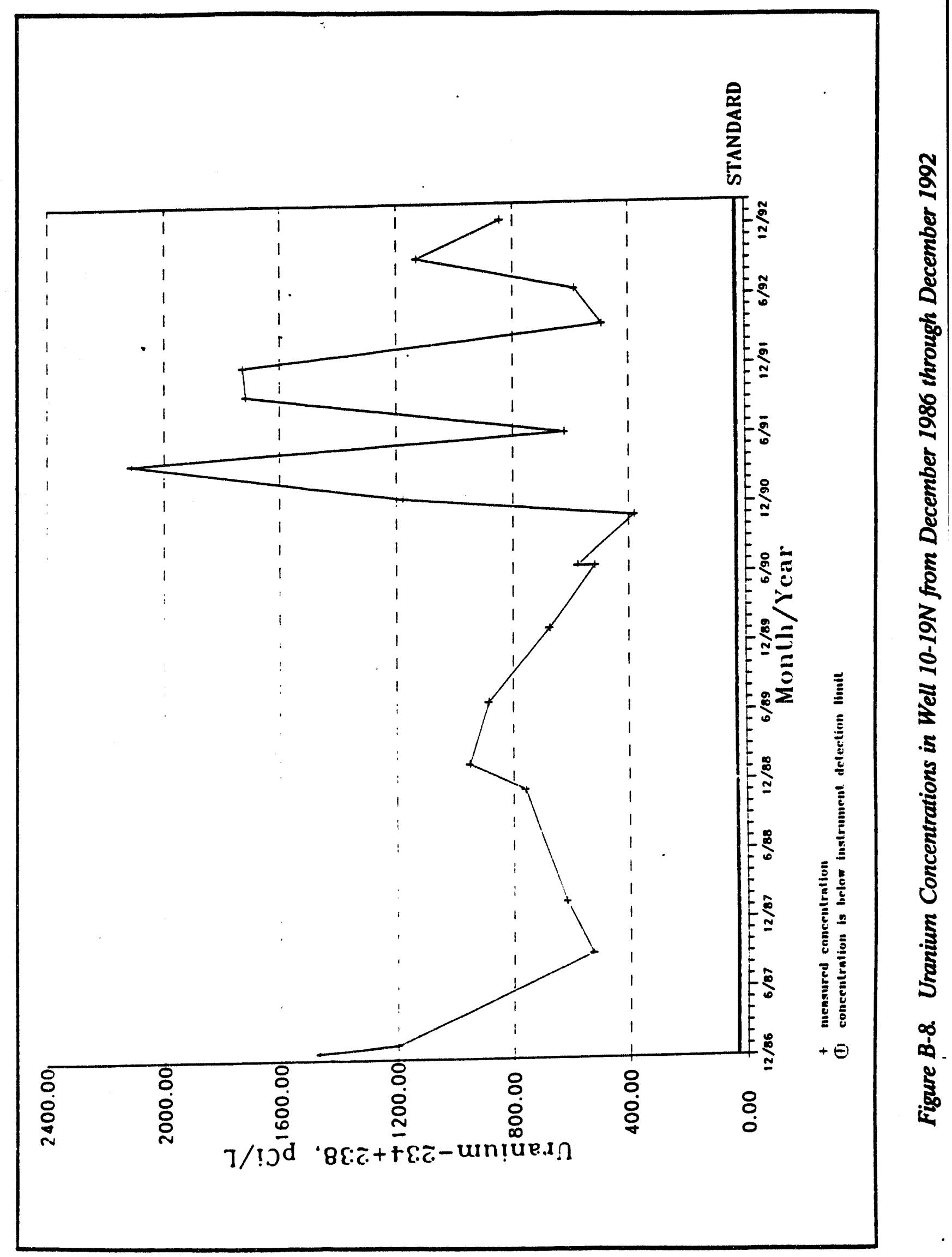




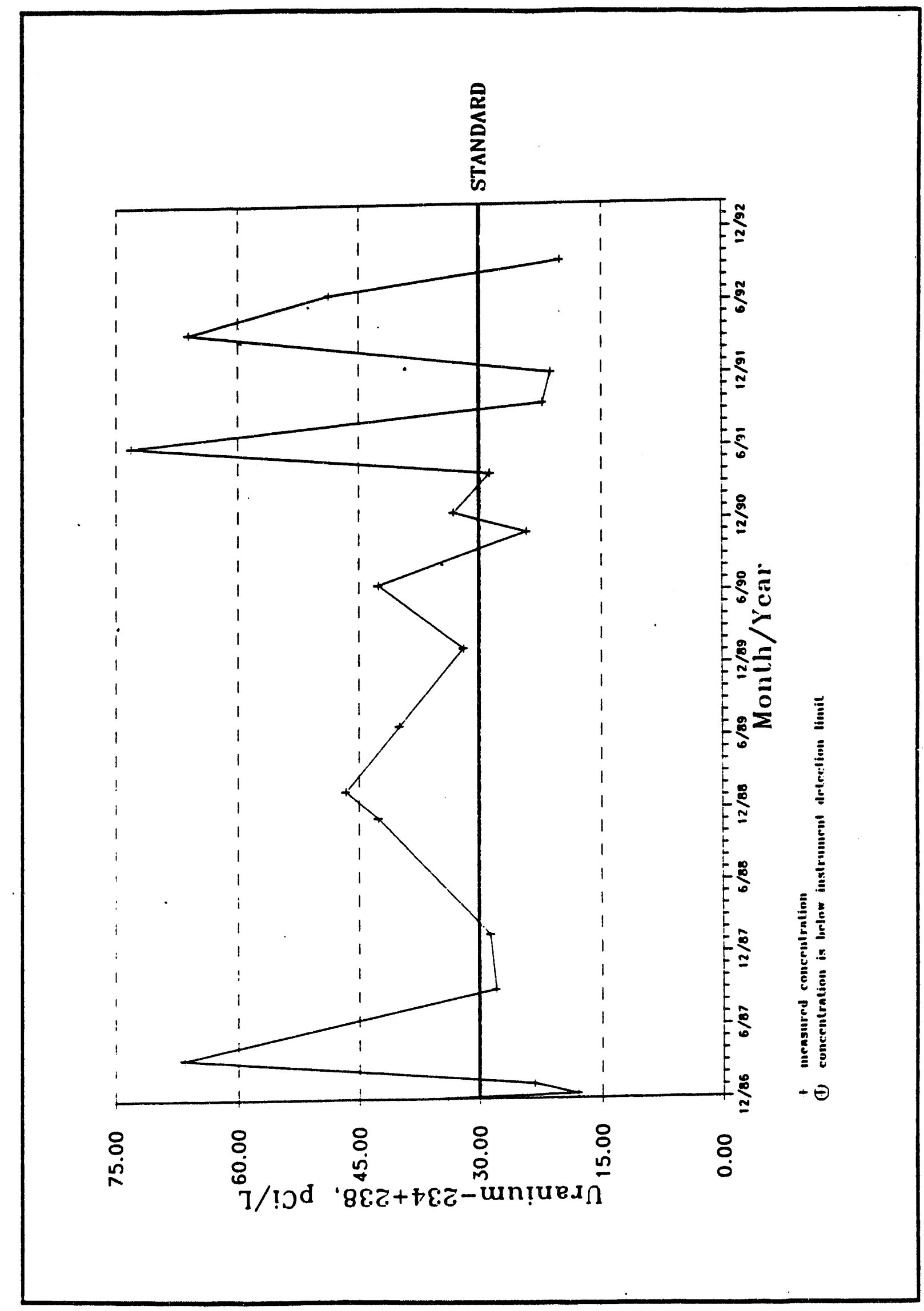

ปู 


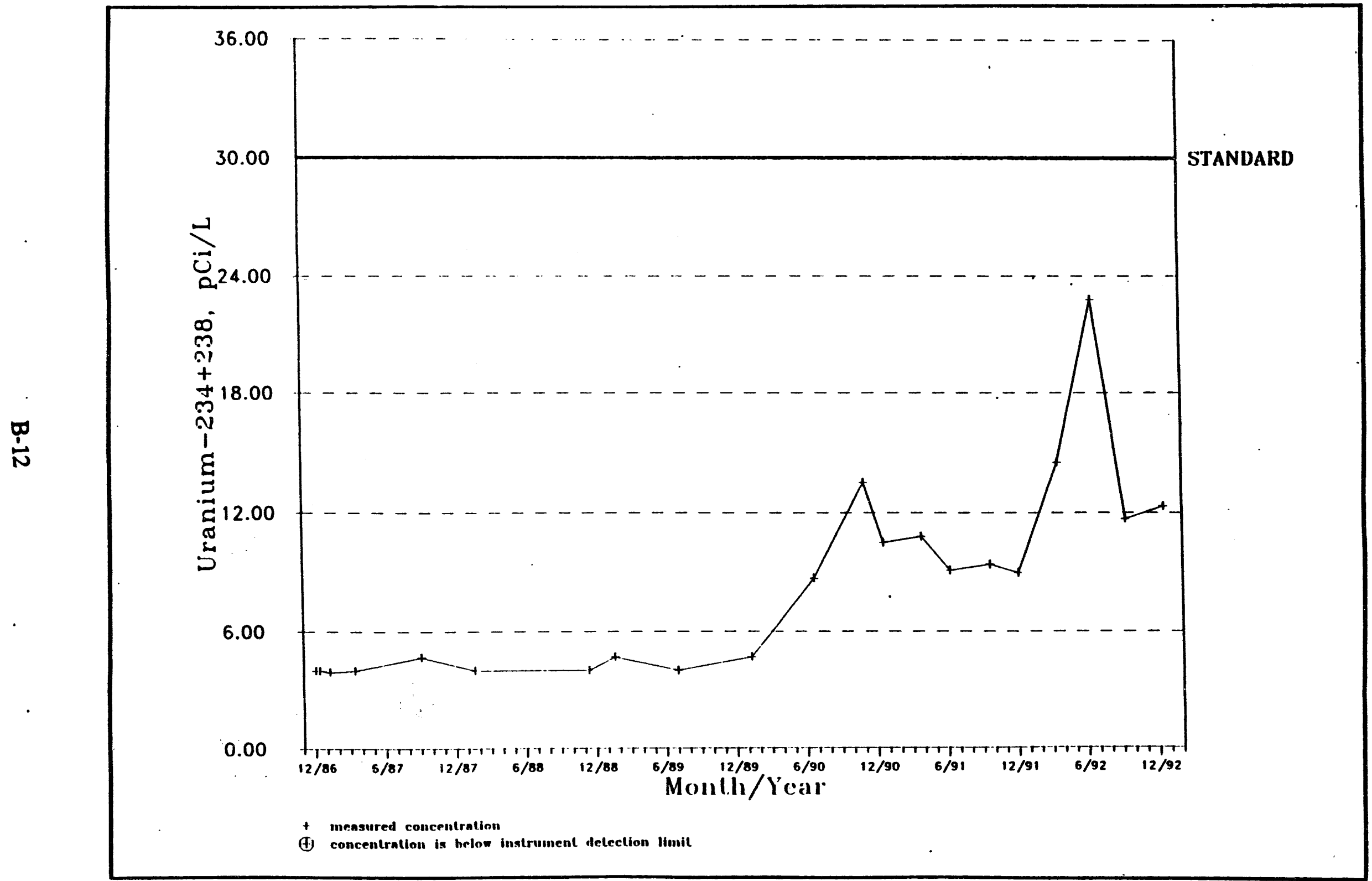

Figure B-10. Uranium Concentrations in Well GJ84-10 from December 1986 through December 1992 


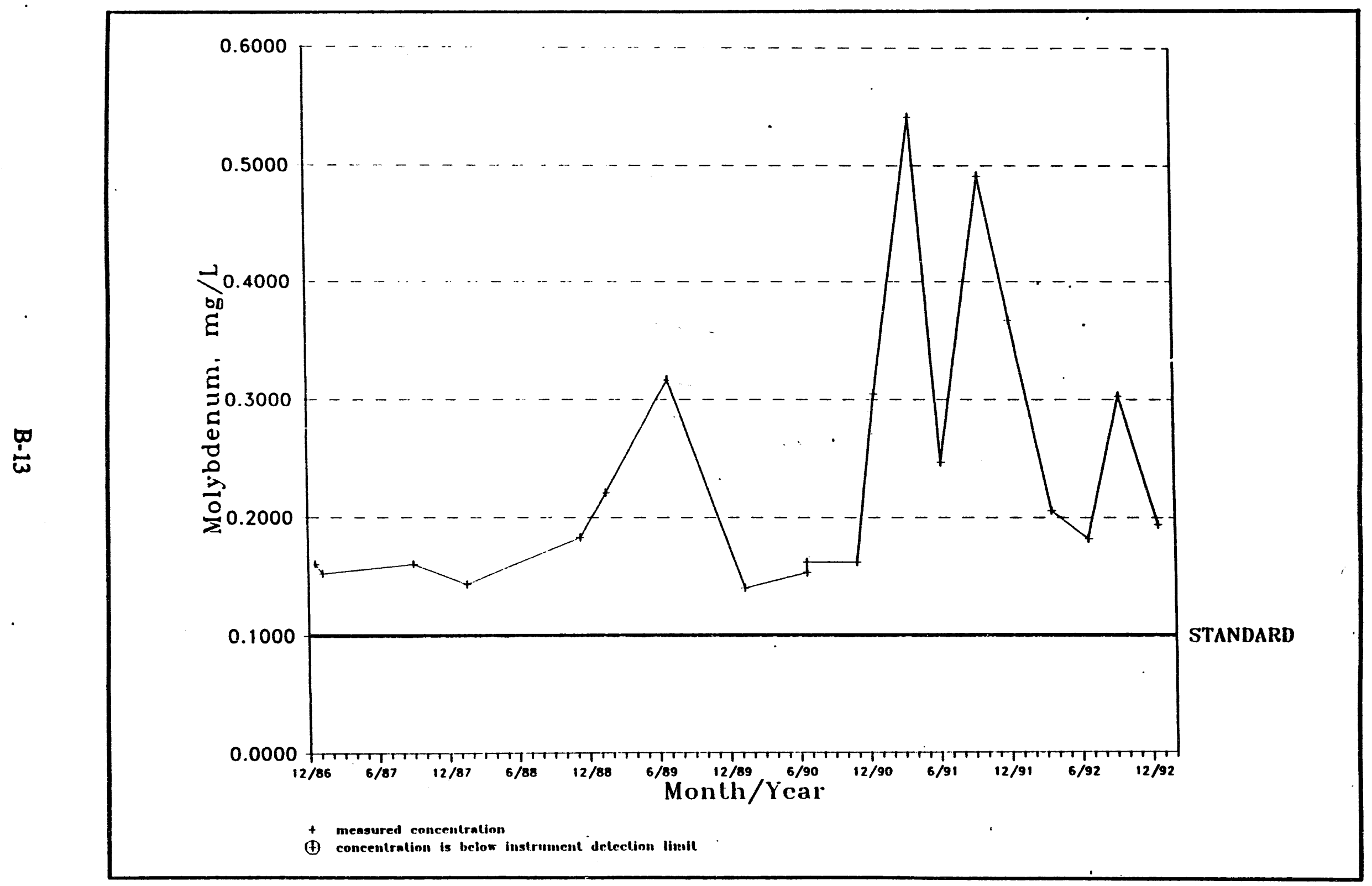

Figure B-11. Molybdenum Concentrations in Well 10-19N from December 1986 through December 1992 


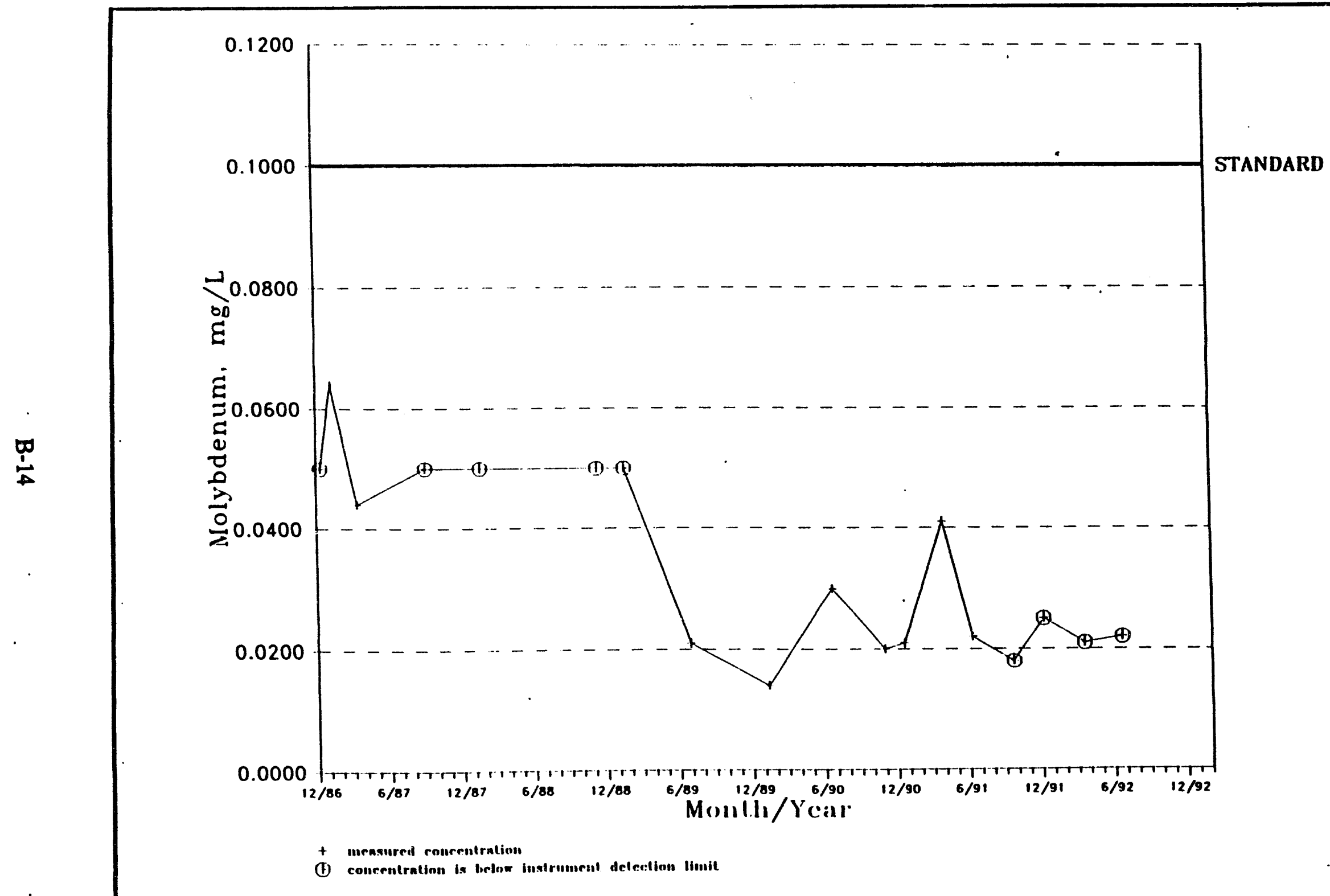

Figure B-12. Molybdenum Concentrations in Well 14-6NA from December 1986 through December 1992 


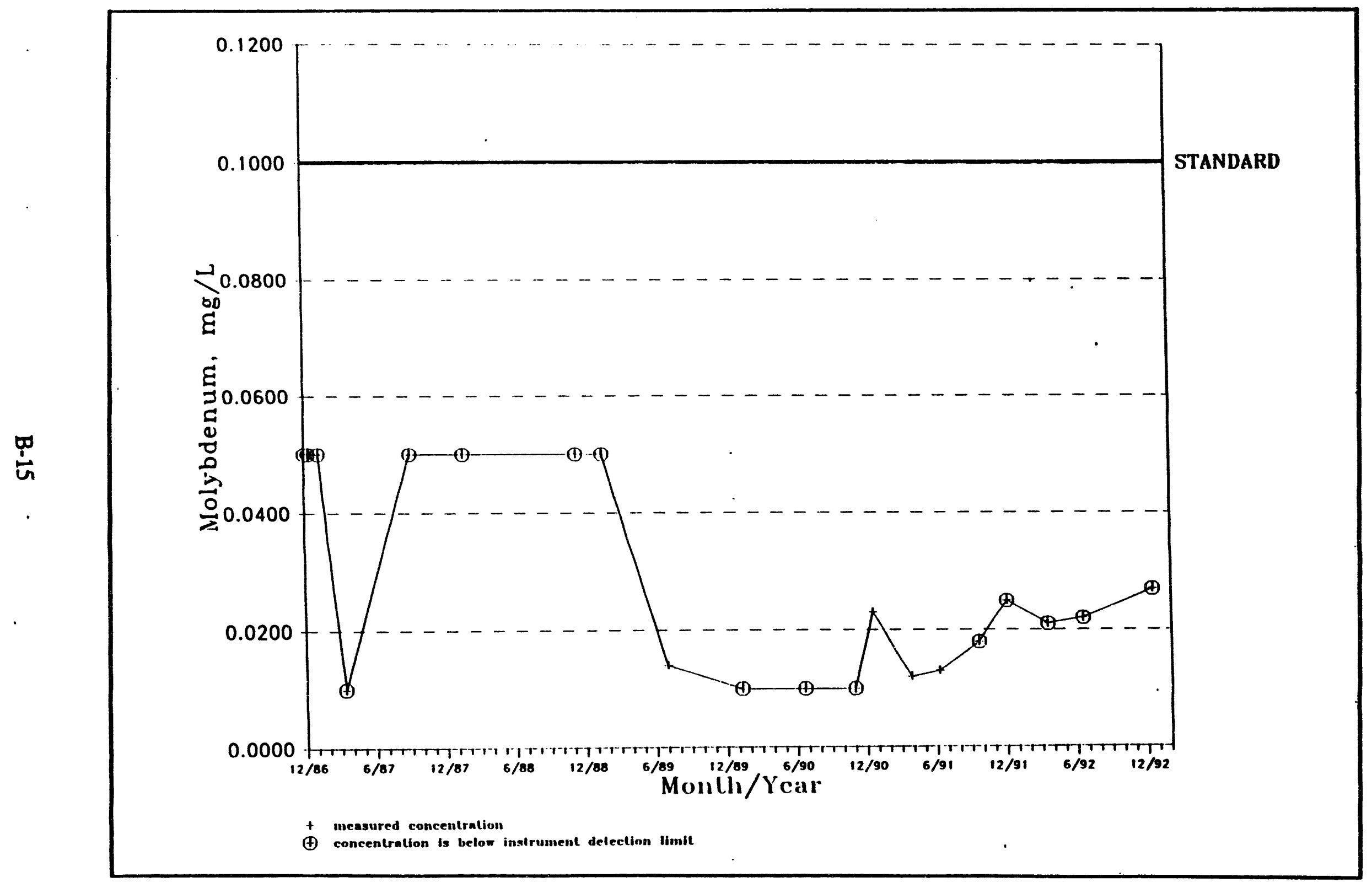

Figure B-13. Molybdenum Concentrations in Well GJ84-10 from December 1986 through December 1992 







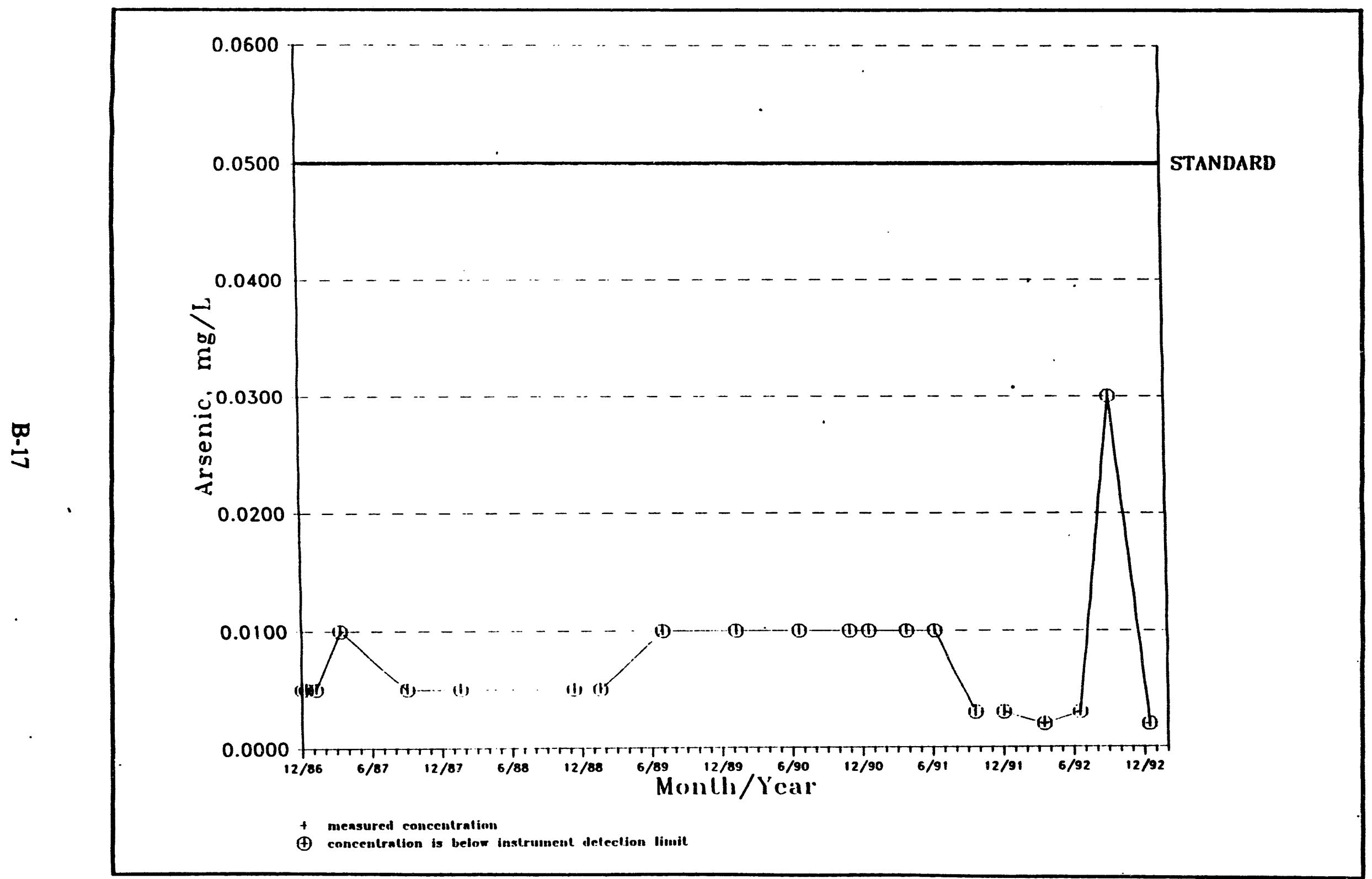

Figure B-15. Arsenic Concentrations in Well GJ84-10 from December 1986 through December 1992 


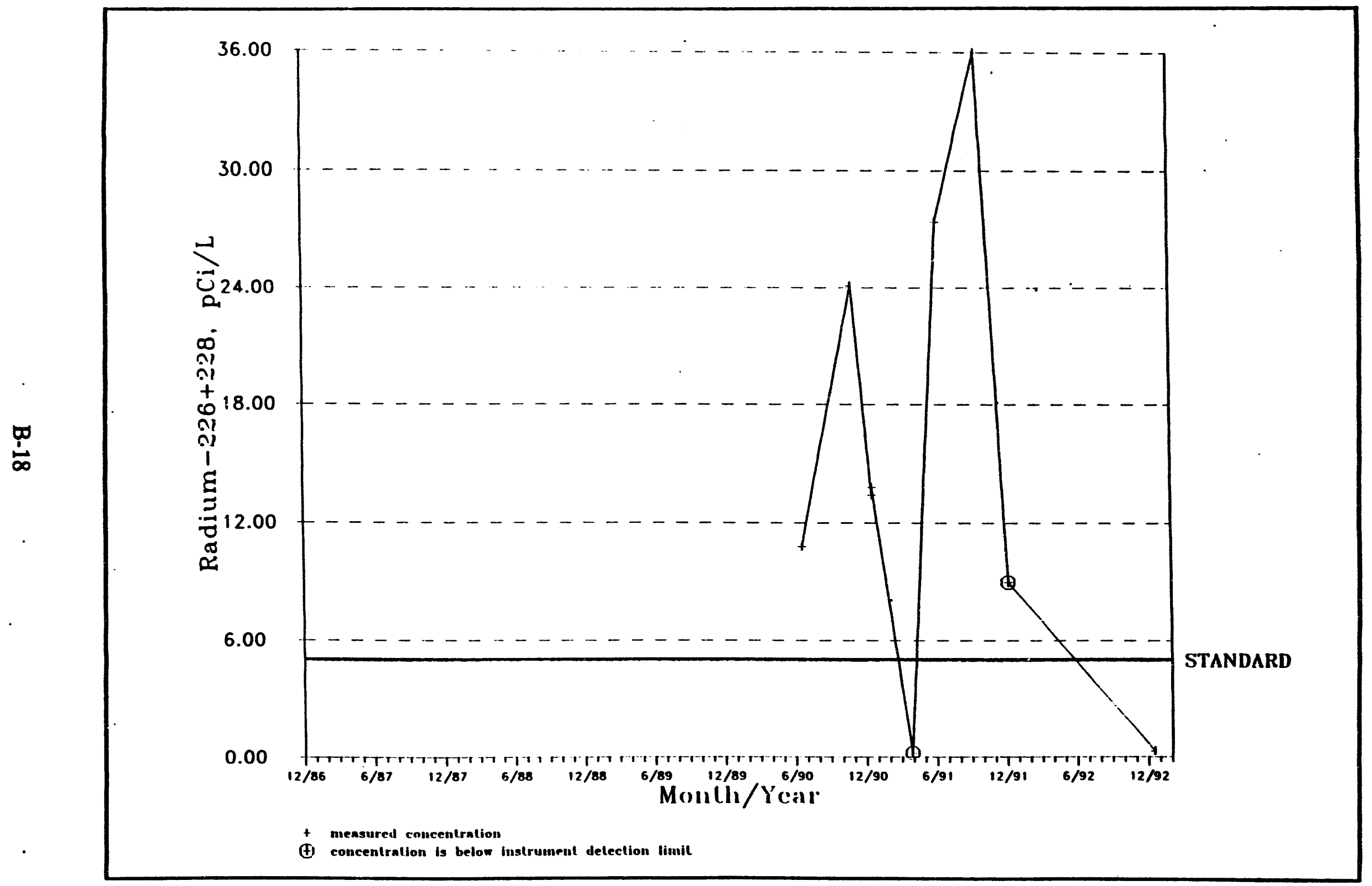

Figure B-16. Radium-226+228 Concentrations in Well 8-4S from June 1990 through December 1992 


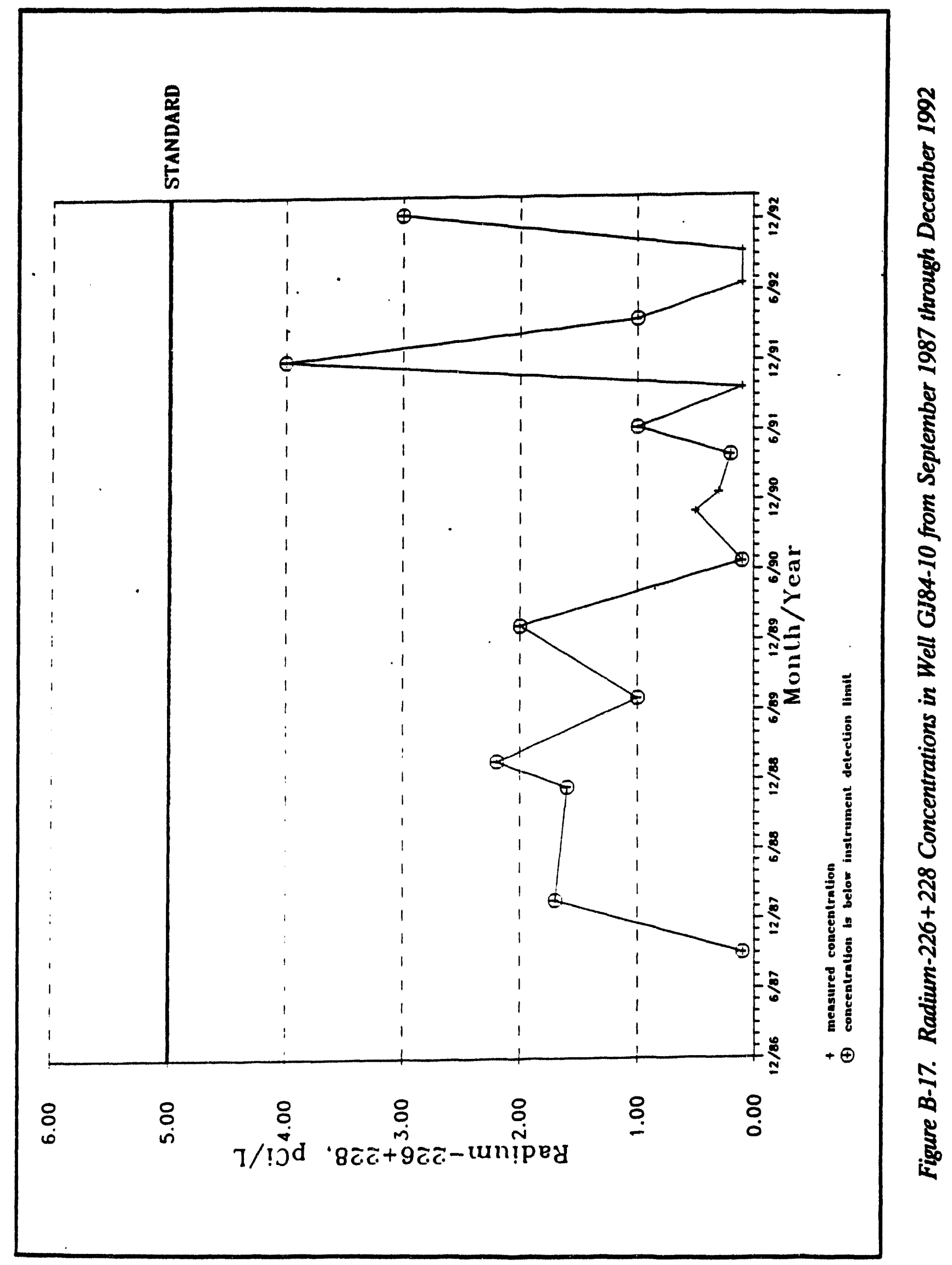






Figure B-18. Selenium Concentrations in Well 8-4S from December 1986 through December 1992 


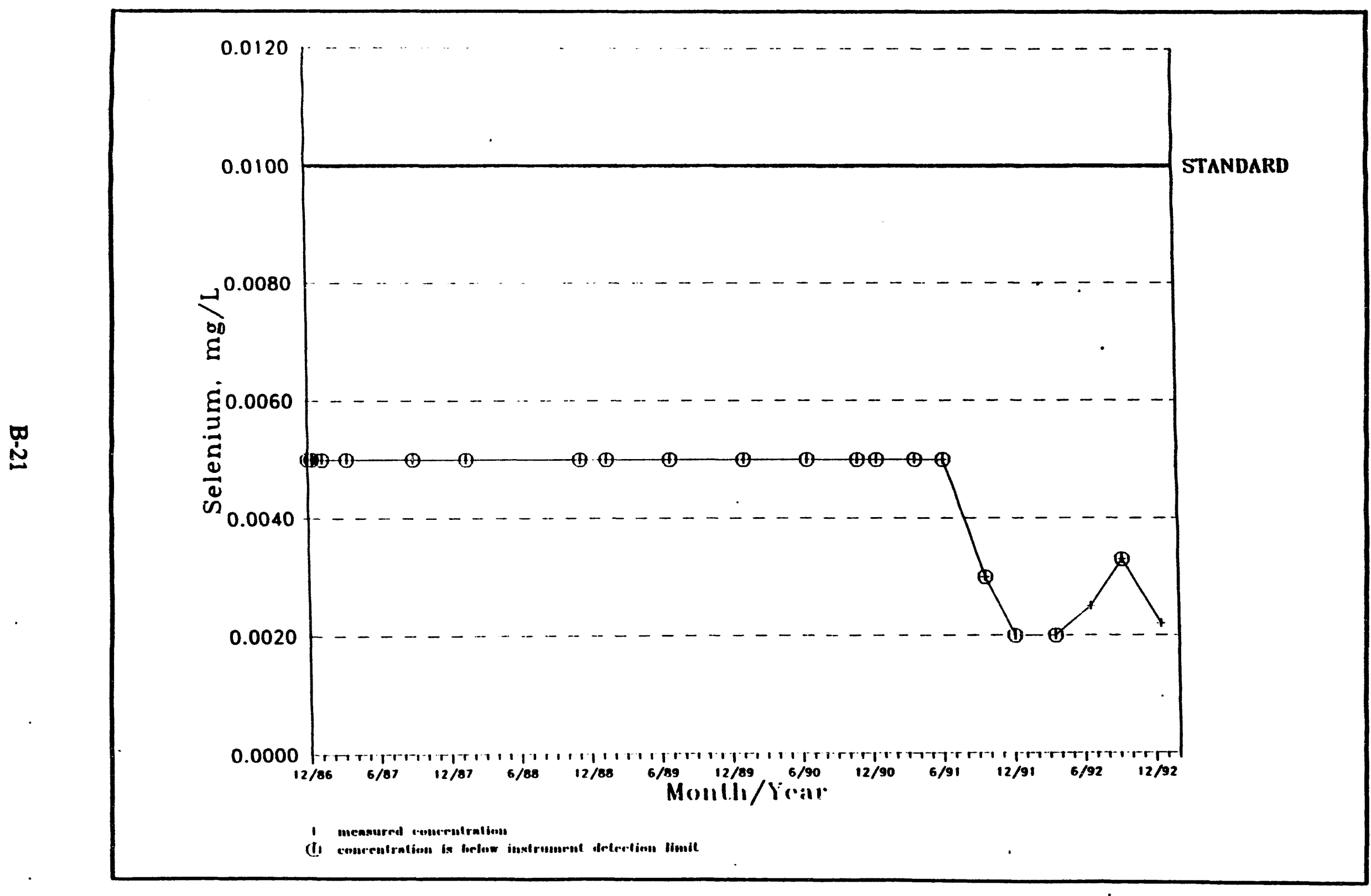

Figure B-19. Selenium Concentrations in Well GJ84-10 from December 1986 through December 1992 


\section{Appendix C}

Well Location Maps Showing Ground-Water Analytes that Exceed Federal/State Standards 


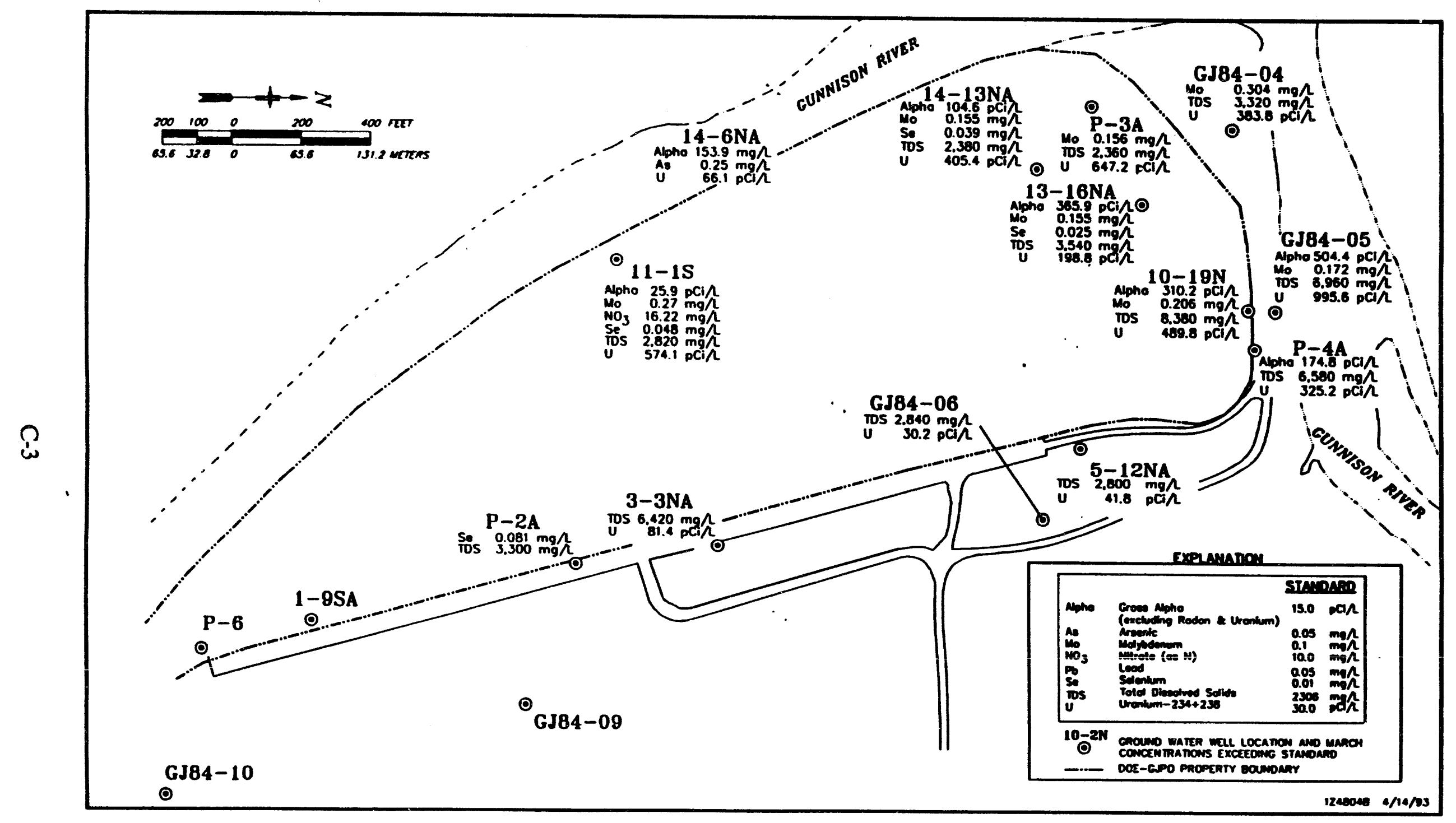

Figure C-1. Concentrations of Ground-Water Analytes Exceeding Federal/State Standards in Alluvial Aquifer Well Samples in March 1992 


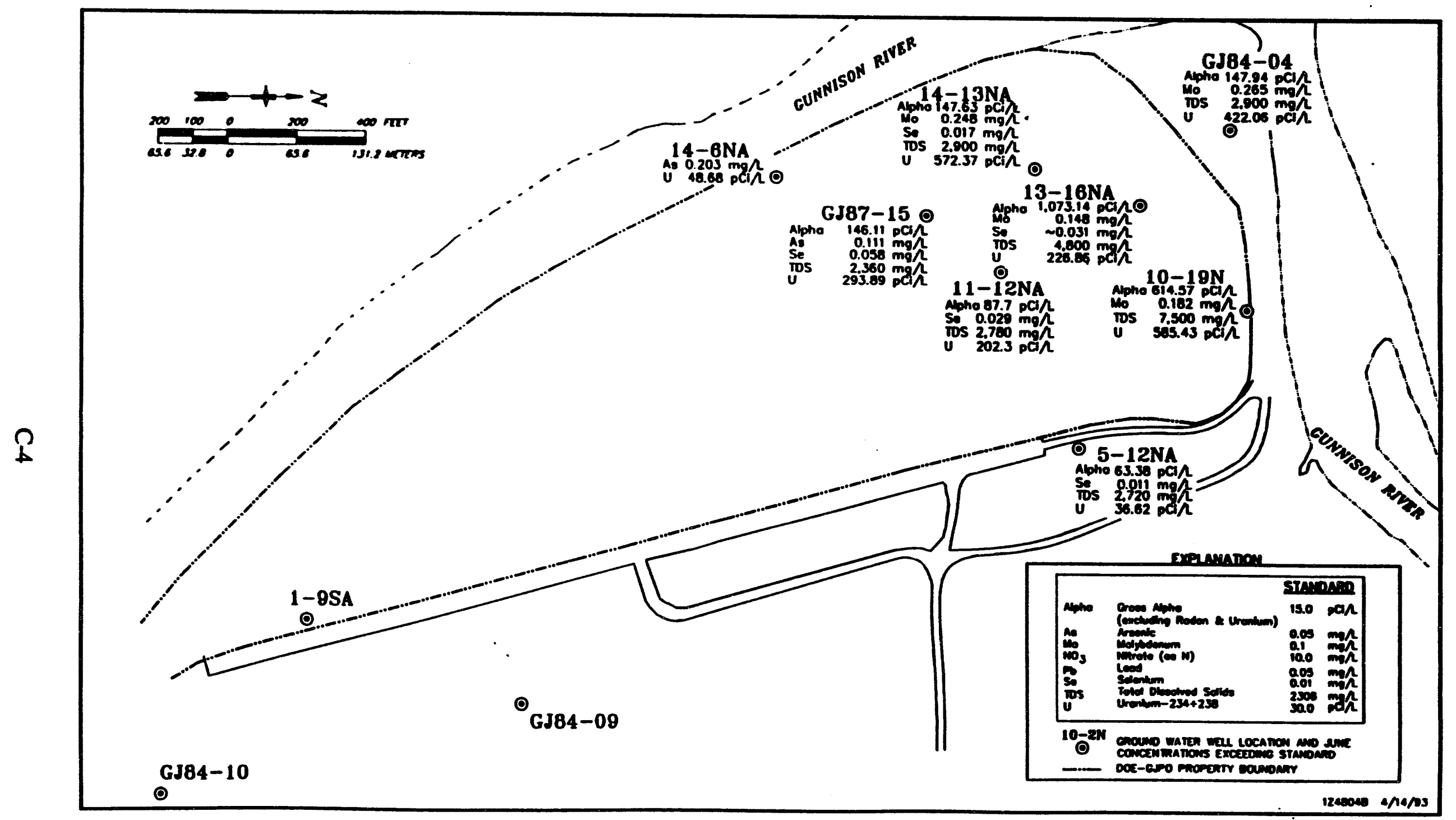

Figure C-2. Concentrations of Ground-Water Analytes Exceeding Federal/State Standards in Alluvial Aquifer Well Samples in June 1992 


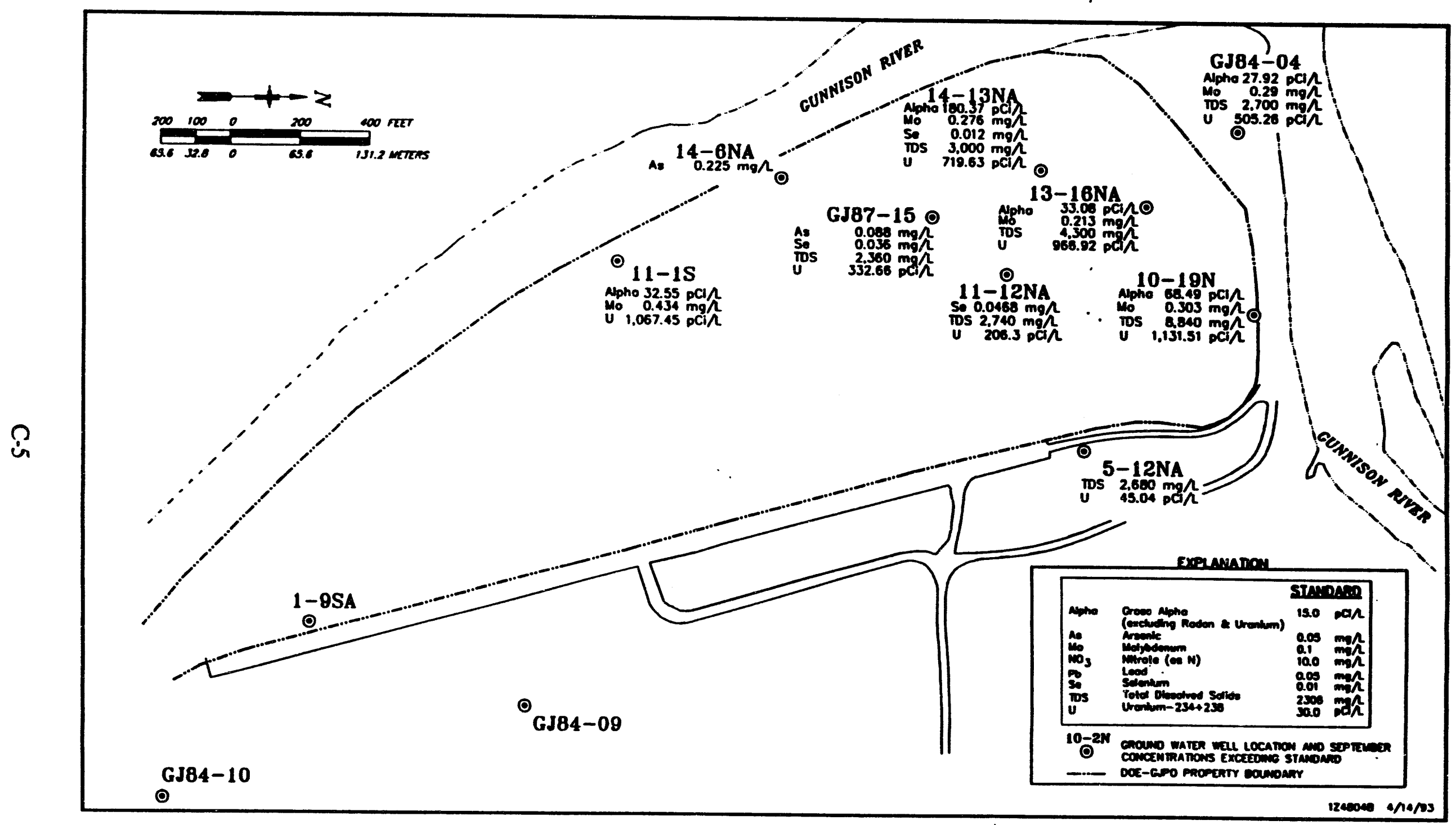

Figure C-3. Concentrations of Ground-Water Analytes Exceeding Federal/State Standards in Alluvial Aquifer Well Samples in September 1992 


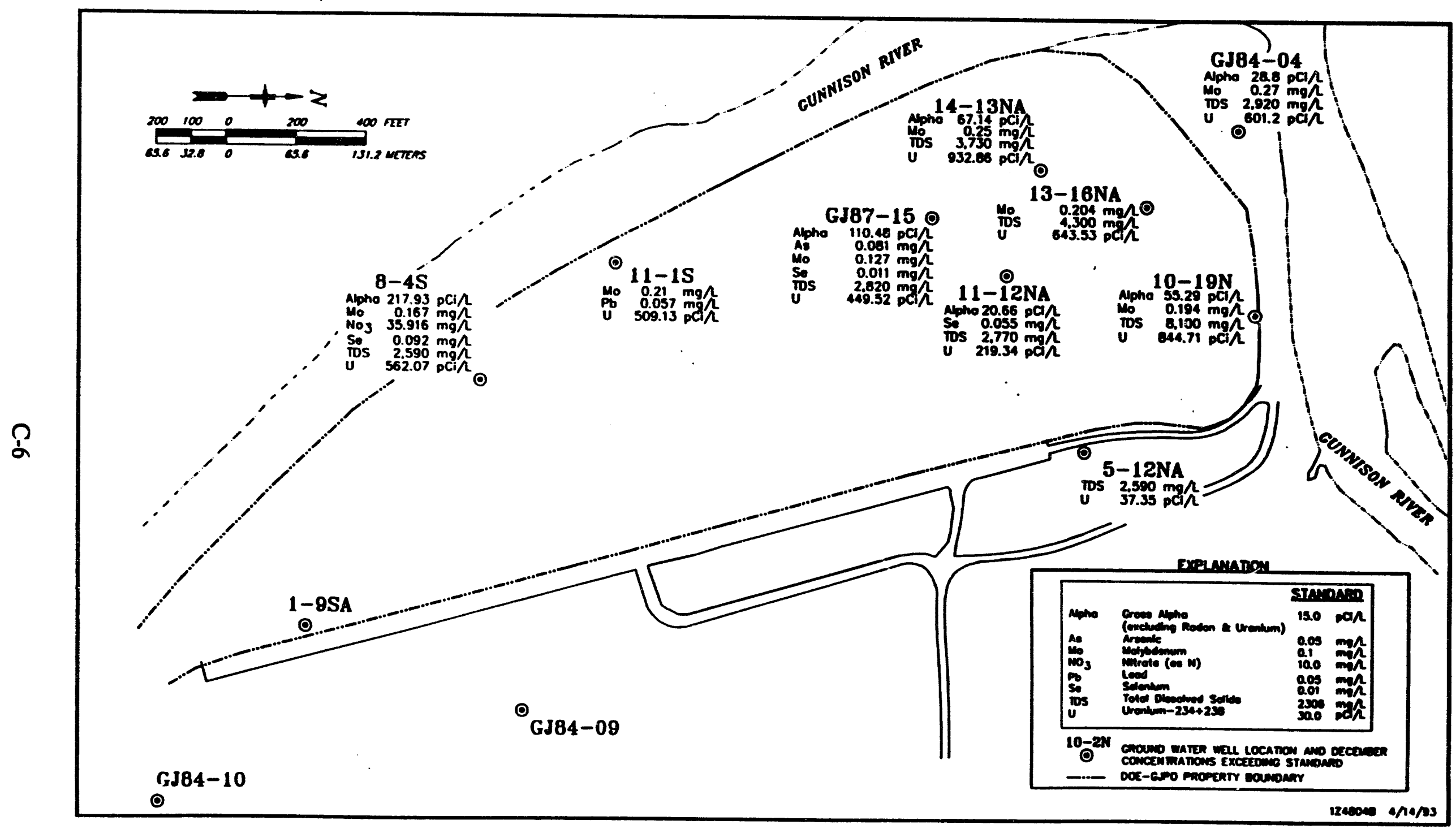

Figure C-4. Concentrations of Ground-Water Analytes Exceeding Federal/State Standards in Alluvial Aquifer Well Samples in December 1992 


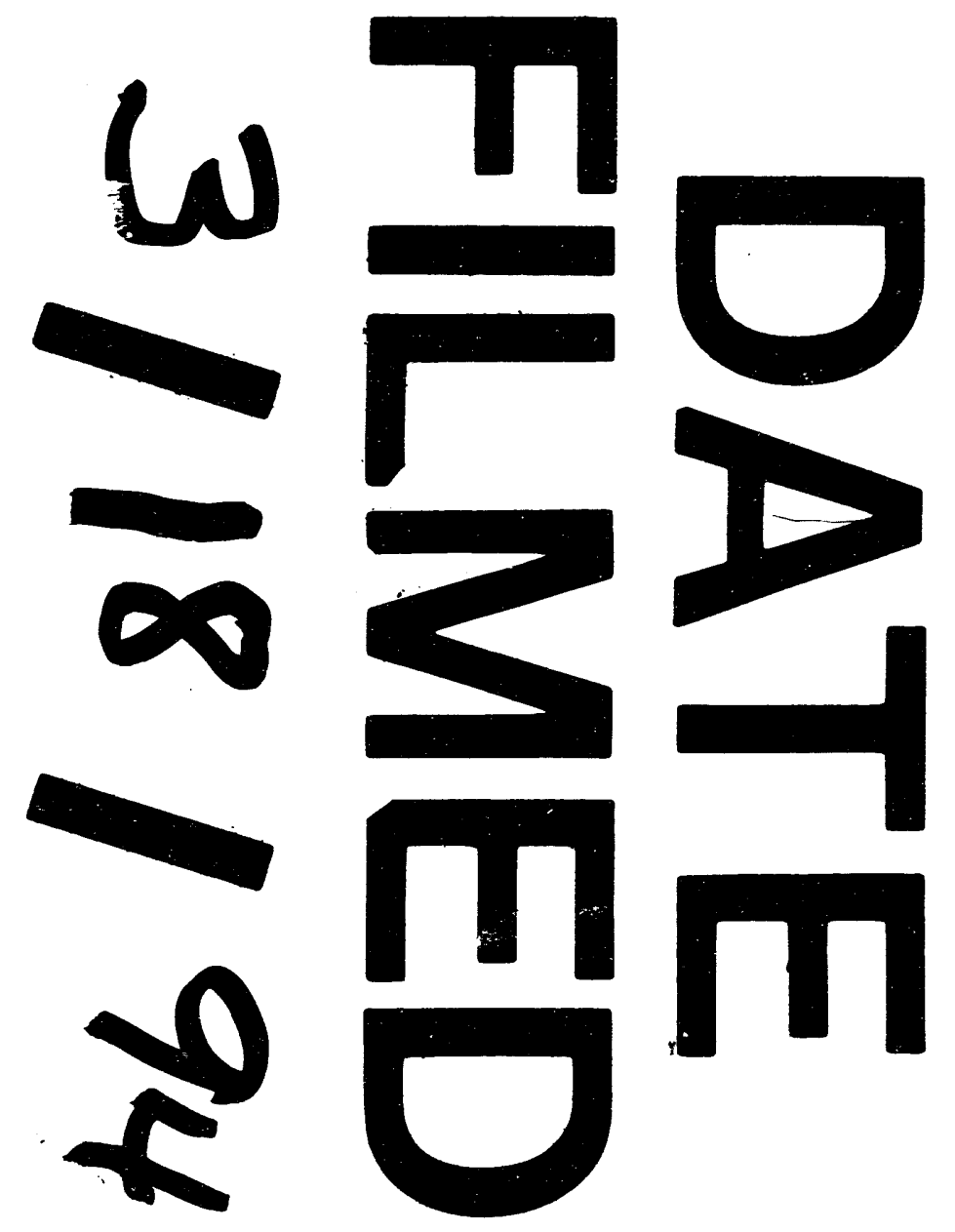


